INSTITUO DE PESQUISAS ENERGÉTICAS E NUCLEARES

"AUTARQUIA ASSOCIADA À UNIVERSIDADE DE SÃO PAULO"

\section{ESTUDO DO APROVEITAMENTO DO RESÍDUO DA LAVOURA CAFEEIRA COMO FONTE DE BIOMASSA NA PRODUÇÃO DE HIDROGÊNIO}

ROSELY DOS REIS ORSINI

Tese apresentada como parte dos requisitos para obtenção do Grau de Doutor em Ciências na Área de Tecnologia Nuclear - Materiais.

Orientadora:

Prof $^{a}$. Dr ${ }^{a}$. Fátima Maria Sequeira de Carvalho

São Paulo 2012 


\section{DEDICATÓRIA}

Dedico este trabalho

Aos meus queridos país Rosalina e Wilson in memorian, $\mathcal{A} o$ meu esposo Carlos Eduardo, exemplo de Amor e dedicação

Ao Bem Amado Mestre Saint Germain 


\section{AGRADECIMENTOS}

À DEUS PAI-MÃE e à minha Amada Presença EU SOU, pelo sopro e manutenção da minha vida.

Agradeço a todos que direta ou indiretamente colaboraram para que este trabalho se realizasse.

À Dra Fátima Maria Sequeira de Carvalho, pelo apoio, incentivo, confiança no meu trabalho e em especial pela sua valiosa amizade.

À Dra Lucildes Pita Mercuri, pelo apoio, carinho, dedicação, pela enorme ajuda e pela recente e profunda amizade.

Ao Dr Jivaldo do Rosário Matos, pela ajuda, apoio e disponibilização do laboratório de análise térmica do Instituto de Química da USP.

Ao Msc Elder Moscardini Filho, pelo apoio e imensa ajuda mesmo quando distante e pela recente e prazerosa amizade.

Ao Dr Ivan Santos, pelo apoio e incentivo para que eu realizasse este trabalho.

Ao Dr Marcelo Linardi, gerente do centro de Células a Combustível e Hidrogênio $(\mathrm{CCCH})$, pela disponibilização das instalações, incentivo e amizade.

Aos amigos do $\mathrm{CCCH}$, Vanderlei, Jamil, Ricardo, Dionísio, Adriana, Roberto e José Carlos, pelo apoio, incentivo, ajuda incondicional, valiosa amizade e carinho, além do convívio alegre e prazeroso.

Ao amigo Mauricio Marques, sempre disponível a me ajudar com a parte de instalação e manutenção do equipamento, agradeço pela atenção e amizade.

À Jéssica, nossa secretária, pelo carinho e recente amizade.

Ao Dr Paulo Ernesto de Oliveira Lainetti do Centro de Química e Meio Ambiente (CQMA), pelo incentivo, disponibilização das instalações que deram início ao trabalho, e principalmente pela compreensão e amizade nos momentos difíceis pelos quais passei.

Aos amigos João Batista e Edson Takeshi que construíram o reator de pirólise e me socorreram todas as vezes que precisei de ajuda no funcionamento do equipamento, minha eterna gratidão pelo incentivo, disponibilidade e amizade. 
Aos amigos do CQMA, Ana, Crhistina, Maria Claudia, Mitiko, Jacinete, Valdelei, Brandão, Valsir, Ricardinho e Renato, por todo carinho e amizade incondicionais.

Às amigas do Ipen, Ilze, Nayara e Sueli, pela amizade eterna, dedicação, carinho, além de força e incentivo.

Aos técnicos que me auxiliaram nas diversas análises: Priscila Oliveira Amaral, Graciele P.da Cruz Gonschorowski, Felipe P. Coelho e Beatriz Galvão, agradeço pelo carinho e atenção.

Aos engenheiros da Cocatrel de Três Pontas que muito gentilmente forneceram os dados técnicos necessários para o processamento da palha do café: Luiz Claudio M. Nogueira e Anderson Sodré e à Sra Monica Chaves Ávila, agradeço pela ajuda e atenção.

Ao Msc Ronaldo N. Medeiros, Vitor W. dos Reis, Oswaldo M. Correia e Irene de Sousa Correia da Fazenda experimental Três Pontas, pela acolhida sempre carinhosa todas as vezes que precisei de matéria-prima, bem como pelos ensinamentos quanto ao processamento e obtenção da palha do café.

Aos meus familiares e amigos pessoais agradeço do fundo do coração pelo incentivo, apoio, carinho e compreensão pela minha ausência durante a realização deste trabalho.

Àqueles que por ventura eu tenha esquecido de mencionar, peço perdão pelo lapso de memória, mas tenham a certeza de estarem sempre presentes em meu coração. 


\section{EPÍGRAFE}

\section{A CARTA DA TERRA}

\section{Preâmbulo}

Estamos diante de um momento crítico na história da Terra, numa época em que a humanidade deve escolher o seu futuro. À medida que o mundo torna-se cada vez mais interdependente e frágil, o futuro enfrenta, ao mesmo tempo, grandes perigos e grandes promessas. Para seguir adiante, devemos reconhecer que, no meio de uma magnífica diversidade de culturas e formas de vida, somos uma família humana e uma comunidade terrestre com um destino comum. Devemos somar forças para gerar uma sociedade sustentável global baseada no respeito pela natureza, nos direitos humanos universais, na justiça econômica e numa cultura da paz. Para chegar a este propósito, é imperativo que nós, os povos da Terra, declaremos nossa responsabilidade uns para com os outros, com a grande comunidade da vida, e com as futuras gerações.

UNESCO - Março, 2000 


\section{RESUMO}

O aproveitamento da palha do café por meio da conversão térmica apresenta-se com uma alternativa para o problema ambiental de descarte e queimadas a céu aberto, evitando a emissão dos gases poluentes na atmosfera, mais conhecidos como gases do efeito estufa (GEE), agregando valor aos resíduos. A palha do café, também conhecida como "casca" do café, foi utilizada in natura, e submetida à pirólise em reator de leito fixo, em escala laboratorial. Os experimentos foram realizados em sistema de bateladas, uma vez que o equipamento é totalmente fechado; a massa de palha do café utilizada foi de $54 \mathrm{~g}$ e parâmetros como pressão de alimentação do gás de aquecimento $\left(5,5 \mathrm{Kgf} / \mathrm{cm}^{2}\right)$, taxa de aquecimento $\left(20{ }^{\circ} \mathrm{C} / \mathrm{min}\right)$, temperatura de operação do reator de pirólise (Tmáx $=708{ }^{\circ} \mathrm{C}$ ) e rendimento gravimétrico tanto da fase sólida quanto da fase líquida, foram estudados definindo as melhores condições de controle do processo. Várias caracterizações utilizando as seguintes técnicas: análise imediata, análise elementar, análise térmica (TG/DTG e DSC) e GC/MS foram realizadas com a palha do café, para que fossem inferidos parâmetros de partida para a pirólise da biomassa. Os produtos sólido (cinzas), líquido (bio-óleo) e gasoso foram coletados avaliando-se os rendimentos e relacionando-os com os parâmetros previamente estabelecidos, sendo submetidos a análises com o objetivo de obter informações que possam contribuir para a sua melhor utilização. Quanto à caracterização dos produtos sólidos, os mesmos apresentaram alto poder calorífico, podendo ser utilizado como combustível. A fração liquida é composta basicamente de hidrocarbonetos oxigenados e aromáticos, caracterizando o bio-óleo como insumo para indústria química. O hidrogênio, objetivo deste trabalho, foi obtido em frações significativas e os resultados mostraram que a temperatura, bem como a taxa de aquecimento influem no rendimento do mesmo. 


\section{ABSTRACT}

The use of coffee straw through the thermal conversion is presented as an alternative to the environmental problem of disposal and burning in the open, avoiding the emission of greenhouse gases in the atmosphere, better known as greenhouse gases (GHGs), and adding value to waste.

The coffee straw, also known as "shell" coffee, was used in nature, and subjected to a fixed bed pyrolysis reactor at laboratory scale. The experiments were carried out in batch system, once the equipment is completely closed; the coffee straw weight used was about $54 \mathrm{~g}$ and parameters such as feed pressure process $(5.5 \mathrm{kgf} / \mathrm{cm} 2)$, heating rate $\left(20{ }^{\circ} \mathrm{C} / \mathrm{min}\right)$, the operating temperature pyrolysis reactor $\left(\operatorname{Tmax}=708{ }^{\circ} \mathrm{C}\right)$ and gravimetric yield of both the solid phase and liquid phase were studied by defining the best conditions for the process control. Several characterizations using the following techniques: proximate analysis, elemental analysis $(\mathrm{CHN})$, thermal analysis (TG / DTG and DSC), and GC-MS analysis were performed with coffee straw, to be inferred starting parameters for the pyrolysis of biomass. The solid product (ash), liquid (bio-oil) and gases were collected by assessing incomes and linking them with the previously established parameters, being subjected to analysis in order to obtain information that can contribute to improved utilization. The solid products characterization, presented a high calorific value and can be used as fuel. The liquid fraction is composed primarily of aromatics and oxygenated hydrocarbons, characterizing the bio-oil as a feedstock for chemical industry. Hydrogen, objective of this study was obtained in significant fractions, the results showed that the temperature and the heating rate improves the hydrogen yield. 


\section{SUMÁRIO}

1 INTRODUÇÃO

2 OBJETIVO 6

$\begin{array}{lll}3 & \text { REVISÃO DA LITERATURA } & 7\end{array}$

$\begin{array}{lll}3.1 & \text { Energia e meio Ambiente } & 7\end{array}$

3.2 Biomassa 21

3.3 Palha do café 31

3.4 Pirólise 38

3.5 Hidrogênio 46

4 MATERIAL E MÉTODOS 57

$\begin{array}{lll}\text { 4.1 Caracterização da biomassa } & 57\end{array}$

$\begin{array}{lll}\text { 4.1.1 Análise imediata } & 59\end{array}$

4.1.1.1 Determinação do teor de umidade 59

4.1.1.2 Determinação do teor do material volátil 59

4.1.1.3 Determinação do teor de cinzas 59

4.1.1.4 Determinação do teor de carbono fixo 59

$\begin{array}{lll}\text { 4.1.2 Análise elementar } & 61\end{array}$

4.1.3 Termogravimetria/Termogravimetria Derivada (TG/DTG) e Calorimetria Exploratória Diferencial (DSC) 62

4.1.4 Cromatografia a gás acoplada a espectômetro de massa (GC/MS) 65

$\begin{array}{lll}4.2 & \text { Reator de pirólise } & 66\end{array}$

$\begin{array}{lll}4.3 & \text { Estudo dos principais parâmetros de processo }\end{array}$

4.3.1 Pressão de alimentação do gás de aquecimento 72

$\begin{array}{lll}\text { 4.3.2 Taxa de aquecimento } & 72\end{array}$

4.3.3 Temperatura de operação do reator de pirólise 72

4.3.4 Rendimento gravimétrico 72

4.4 Caracterização dos produtos do processo de pirólise 73

4.4.1 Análise elementar CHN das cinzas 73

4.4.2 Caracterização do bio-óleo por GC-MS 74

$\begin{array}{lll}\text { 4.4.2.1 Bio-óleo } & 74\end{array}$

$\begin{array}{lll}\text { 4.4.2.2 Bio-óleo esterificado } & 75\end{array}$ 
4.4.3 Análise do hidrogênio por cromatografia a gás 76

5 RESULTADOS E DISCUSSÕES 78

$\begin{array}{lll}5.1 & \text { Caracterização da biomassa } & 78\end{array}$

$\begin{array}{lll}5.1 .1 & \text { Análise imediata } & 78\end{array}$

5.1.2 Análise elementar 80

5.1.3 Termogravimetria/Termogravimetria Derivada (TG/DTG) e Calorimetria Exploratória Diferencial (DSC) 82

5.1.3.1 Palha Interna 82

5.1.3.2 Palha Externa 84

5.1.3.3 Mistura das palhas interna e externa 87

5.1.4 Cromatografia a gás acoplado a Espectrometria de massas 94 (GC/MS) 90

5.2 Estudo dos principais parâmetros de processo 103

5.2.1 Pressão de alimentação do gás de aquecimento 103

5.2.2 Temperatura de operação e taxa de aquecimento 106

$\begin{array}{ll}5.2 .3 \text { Rendimento gravimétrico } & 113\end{array}$

5.3 Caracterização dos produtos do processo de pirólise 114

$\begin{array}{ll}\text { 5.3.1 Análise elementar das cinzas } & 114\end{array}$

5.3.2 Caracterização do bio-óleo por GC/MS 115

$\begin{array}{lll}\text { 5.3.2.1 Bio-óleo } & 115\end{array}$

$\begin{array}{lll}\text { 5.3.2.2 Bio-óleo esterificado } & 120\end{array}$

5.3.3 Análise do hidrogênio por cromatografia a gás 123

6 CONSIDERAÇÕES FINAIS 128

7 REFERÊNCIAS BIBLIOGRÁFICAS 132 


\section{LISTA DE FIGURAS}

FIGURA $1 \quad$ Esquema representativo do processo da pirólise de biomassa 4

FIGURA 2 Imagem de satélite mostra a nuvem de poluição particulada da Ásia entre a Coréia e o Japão

FIGURA 3 Ranking de países com melhor infraestrutura e adequação tecnológica em energia renovável em 2011

FIGURA 4 Fontes de energia renováveis

FIGURA 5 Capacidade anual instalada de usinas térmicas à biomassa no mundo com previsão para 2013

FIGURA 6 Matriz de oferta de energia elétrica do Brasil - 2007 (\%)

FIGURA 7 Geração de eletricidade por fontes renováveis

FIGURA 8 Prospecção da utilização da biomassa como fonte para geração de aquecimento e eletricidade

FIGURA 9 Ciclo "carbonicamente neutro" da biomassa

FIGURA $10 \quad$ Fluxograma da diferentes fontes de biomassa 23

FIGURA 11 Oferta interna de energia elétrica por fonte no Brasil em 2010

FIGURA 12 Produtos obtidos a partir das diversas biomassas encontradas no Brasil

FIGURA 13 Principais tecnologias de conversão da biomassa

FIGURA 14 Palha do café

FIGURA 15 Sistema convencional de produção do grão de café, torrefação e moagem para utilização na bebida

FIGURA 16 Estrutura do grão de café

FIGURA 17 Hidrogênio para fins energéticos

FIGURA 18 Processo de produção e abastecimento de hidrogênio por eletrólise

FIGURA 19 Esquema do primeiro experimento de uma célula a combustível realizado por Grove em 1839

FIGURA 20 Esquema simplificado de uma célula a combustível

FIGURA 21 Investimentos em hidrogênio e células a combustível no período de 1999 a 2007 
FIGURA 22 Ônibus movido a hidrogênio circulando em São Bernardo do Campo em São Paulo (a) e na cidade do Rio de Janeiro (b)

FIGURA 23 Esquema ilustrativo da obtenção da palha do café na Fazenda Experimental Três Pontas

FIGURA 24 Equipamento para análise elementar

FIGURA 25 Equipamentos TGA-51 (a) e DSC-50 (b) utilizados para a determinação do comportamento térmico da biomassa do café

FIGURA 26 llustração que mostra detalhes das palhas interna (a) e externa (b) do café

FIGURA 27 Disposição das diferentes "pilhas" das palhas interna (a) e externa (b) do café, em fazenda com mecanização na etapa de beneficiamento

FIGURA 28 Equipamento de GC/MS utilizado para a identificação dos compostos químicos presentes na biomassa do café

FIGURA 29 Projeto piloto do reator de pirólise do IPEN

FIGURA 30 Sistema completo montado do processo de pirólise (IPEN)

FIGURA 31 Corpo do reator acoplado ao flange (a) e detalhe da parte inferior totalmente fechada (b) do reator de pirólise

FIGURA 32 Sistema de flangeamento do reator de pirólise acoplado ao condensador

FIGURA 33 Sistema inferior do reator de pirólise do IPEN acoplado ao maçarico

FIGURA 34 Detalhe do encamisamento do reator de pirólise do IPEN

FIGURA 35 Detalhe do orifício da grelha por onde se acende o reator de pirólise

FIGURA 36 Ilustração das cinzas provenientes do produto da pirólise

FIGURA 37 Extração da fração orgânica do bio-óleo com diclorometano para preparação da análise de GC/MS

FIGURA 38 Sistema de refluxo e reagentes utilizados para a esterificação do bio-óleo $\quad 75$

FIGURA 39 llustração do cromatógrafo utilizado nas análises dos gases

FIGURA 40 llustração do procedimento de retirada de amostra dos gases do processo de pirólise para análise, em tempo real, em 
cromatógrafo a gás

FIGURA 41 Curvas TG/DTG da amostra da palha interna do café 82

FIGURA 42 Curva DSC da amostra da palha interna do café 83

FIGURA 43 Curvas TG/DTG da amostra da palha externa do café $\quad 84$

FIGURA 44 Curva DSC da amostra da palha externa do café $\quad 85$

$\begin{array}{lll}\text { FIGURA } 45 & \text { Curvas TG/DTG da amostra da mistura da palha do café } & 87\end{array}$

FIGURA 46 Curva DSC da amostra da mistura da palha do café 88

FIGURA 47 Extratos de palha do café obtidos com diferentes tipos de solventes

FIGURA 48 Recipientes contendo os extratos diluídos para utilização nas medidas por GC/MS

FIGURA 49 Cromatograma do extrato da amostra da palha do café seca, diluída em hexano, obtido por GC/MS no modo SCAN

FIGURA 50 Cromatograma do extrato da amostra da palha do café in natura, diluída em hexano, obtido por GC/MS no modo SCAN

FIGURA 51 Cromatograma do extrato da palha do café seca, diluída em acetonitrila, obtido por GC/MS no modo SCAN

FIGURA 52 Cromatograma do extrato da palha do café in natura, diluída em acetonitrila, obtido por GC/MS no modo SCAN

FIGURA 53 Cromatograma do extrato da palha do café seca, diluída em diclorometano, obtido por GC/MS no modo SCAN

FIGURA 54 Cromatograma do extrato da palha do café in natura, diluída em diclorometano, obtido por GC/MS no modo SCAN

FIGURA 55 Espectro de massas do composto Dietil ftalato 96

FIGURA 56 Espectro de massas do composto Cafeína 97

FIGURA 57 Espectro de massas do composto Ácido 1,2Benzenodicarboxilico, di(2-metilpropil) éster

FIGURA 58 Espectro de massas do composto Dodecanamida ou Lauramida

FIGURA 59 Espectro de massas do composto 9-Octadecenamida ou Adogen 73

FIGURA 60 Fórmula estrutural dos principais compostos químicos presentes na palha do café determinados por GC/MS 
FIGURA 61 Variação do volume do bio-óleo nas pressões de 4,8 e $5,5 \mathrm{kgf} / \mathrm{cm}^{2}$ de alimentação do gás de aquecimento em 18 bateladas do processo de pirólise da palha do café

FIGURA 62 Variação da massa de cinzas nas pressões de 4,8 e $5,5 \mathrm{kgf} / \mathrm{cm}^{2}$ de alimentação do gás de aquecimento, em 18 bateladas do processo de pirólise da palha do café

FIGURA 63 Percentuais de hidrogênio obtidos nas pressões de 4,8 e $5,5 \mathrm{kgf} / \mathrm{cm}^{2}$ de alimentação do gás de aquecimento, nas 18 bateladas

FIGURA 64 Temperaturas máximas atingidas no processo de pirólise da palha do café e o tempo para atingí-las em 18 diferentes bateladas

FIGURA 65 Temperatura de operação e taxa de aquecimento (bateladas 1 a 9) da pirólise da palha do café

FIGURA 66 Temperatura de operação e taxa de aquecimento (bateladas 10 a 18) da pirólise da palha do café

FIGURA 67 Taxa de aquecimento média das bateladas de 1 a 9 no processo de pirólise da palha do café

FIGURA 68 Taxa de aquecimento média das bateladas de 10 a 18 no processo de pirólise da palha do café

FIGURA 69 Média das temperaturas de condensação dos produtos de menor temperatura de ebulição em função do tempo

FIGURA 70 Média da temperatura da condensação do bio-óleo em função do tempo no processo

FIGURA 71 Cromatograma da análise qualitativa do bio-óleo em repouso por mais de 100 dias, obtido por GC/MS no modo SCAN

FIGURA 72 Cromatograma da análise qualitativa do bio-óleo em repouso por menos de 100 dias, obtido por GC/MS no modo SCAN 116

FIGURA 73 Fórmula estrutural dos principais compostos químicos presentes no bio-óleo obtido da pirólise da palha do café determinados por GC-MS

FIGURA 74 Bio-óleo com tempo de repouso superior e inferior a 100 dias

FIGURA 75 Cromatograma da análise qualitativa do bio-óleo esterificado, 
obtido por GC/MS no modo SCAN

FIGURA 76 Fórmulas estruturais dos principais compostos químicos presentes no bio-óleo esterificado obtido da pirólise da palha do café determinados por GC/MS

FIGURA 77 Cromatograma do hidrogênio obtido no processo da batelada 8 (amostra 1)

FIGURA 78 Cromatograma do hidrogênio obtido no processo da batelada 8 (amostra2)

FIGURA 79 Cromatograma do hidrogênio obtido no processo da batelada 9 (amostra 1)

FIGURA 80 Cromatograma do hidrogênio obtido no processo da batelada 9 (amostra 2)

FIGURA 81 Cromatograma do hidrogênio obtido no processo da batelada 13 (amostra 1)

FIGURA 82 Cromatograma do hidrogênio obtido no processo da batelada 13 (amostra 2)

FIGURA 83 Evolução do teor de hidrogênio em função da temperatura no processo de pirólise da palha do café 


\section{LISTA DE TABELAS}

TABELA 1 Maiores produtores de café do Brasil

TABELA 2 Produção de carvão mineral, em milhões de toneladas equivalentes de petróleo (Mtep), dos principais produtores mundiais em $2010 \quad 8$

TABELA $3 \quad$ Fator do potencial de aquecimento global dos GEE 13

TABELA 4 Consumo mundial de energia primária (Mtep) 24

TABELA $5 \quad$ Produtos de pirólise da biomassa 41

TABELA 6 Classificação das principais células a combustível 52

TABELA 7 Teores de umidade, voláteis, cinzas e carbono fixo da análise imediata da palha do café $\quad 78$

TABELA 8 Dados do poder calorífico superior de diferentes biomassas (base seca) $\quad 80$

TABELA 9 Dados obtidos da análise elementar da palha do café $\quad 81$

TABELA 10 Composição elementar de diferentes biomassas (base seca) 81

TABELA 11 Perda de massa (\%) em relação à temperatura de decomposição (\%) de cada evento térmico das palhas interna e externa do café

TABELA 12 Variação de entalpia, temperaturas onset e de pico para as amostras das palhas interna e externa do café

TABELA 13 Perda de massa (\%) em relação à temperatura de decomposição (\%) de cada evento térmico da palha do café

TABELA 14 Dados de entalpia, temperaturas onset e de pico para a amostra da palha do café

TABELA 15 Principais compostos químicos identificados no extrato obtido da palha do café determinados por GC/MS

TABELA 16 Rendimento gravimétrico médio das fases sólida e líquida da pirólise da palha do café

TABELA 17 Dados da análise elementar média das cinzas obtidas no processo de pirólise da palha do café

TABELA 18 Principais compostos químicos presentes no bio-óleo obtido no processo de pirólise da palha do café determinados por 
TABELA 19 Principais compostos químicos do bio-óleo esterificado obtido do processo de pirólise da palha do café determinados por GC/MS 


\begin{abstract}
"A energia é essencial para que se atinjam os objetivos econômicos, sociais e ambientais inter-relacionados do desenvolvimento sustentável. Mas para alcançar essa importante meta, os tipos de energia que produzimos e as formas como os utilizamos terão de mudar. Do contrário, danos ao meio ambiente ocorrerão mais rapidamente, a desigualdade aumentará e o crescimento econômico global será prejudicado" (UNDP World Energy Assessment: Energy and the Challenge of Sustainability) ${ }^{[1]}$.
\end{abstract}

A busca pelo aumento da capacidade instalada de energia elétrica, aliada à necessidade de se reduzir emissões de poluentes, vem dando forças às fontes de energia alternativas.

Atualmente, há programas no mundo inteiro de incentivos a tais fontes, visto que o caráter não renovável dos combustíveis fósseis utilizados até então vem causando preocupação, tanto quanto ao possível esgotamento, uma vez que as previsões de aproveitamento são para mais 40 ou 50 anos, como à quantidade de poluentes emitidos no seu uso, que vem causando alterações atmosféricas como a intensificação do efeito estufa ${ }^{[2-4]}$.

As energias não renováveis são oriundas de um processo de milhões de anos de decomposição orgânica que foram se acumulando ao longo das eras no subsolo terrestre, formando as chamadas "fontes fósseis de energia", que durante anos a fio foram utilizadas na produção de energia. Essas fontes fósseis tais como o petróleo, o carvão e o gás natural, são de reservas finitas, assim como, alguns elementos químicos que podem gerar energia como, por exemplo, o urânio, fonte primária da energia nuclear ${ }^{[5]}$.

É importante lembrar, que o fato das maiores jazidas fósseis estarem concentradas em poucas regiões do planeta faz com que seu preço varie em função dos interesses de seus produtores ${ }^{[6]}$. 
Tendo em vista esse enfoque, as fontes renováveis de energia terão participação cada vez mais relevante na matriz energética global nas décadas vindouras podendo chegar a $10 \%$ em $2020^{[7]}$.

Segundo Vasconcellos em seu livro : Biomassa - A eterna energia do Futuro [8], "as vantagens de um programa de desenvolvimento de fontes renováveis de origem vegetal, substituindo a energia fóssil do carvão mineral e do petróleo, são de ordem ecológica e sociopolítica, porque é uma forma de energia limpa e pacífica, criadora de empregos, descentralizadora de renda, de poder e de população".

Desta forma, pesquisas para obtenção e uso de combustíveis renováveis visando a geração de energia e que sejam menos agressivas ao meio ambiente, têm sido desenvolvidas por instituições em diversas partes do mundo.

Uma das maneiras de se obter energia de fonte renovável é por meio do aproveitamento de biomassa como, por exemplo, a palha do café.

O Brasil é o maior produtor mundial de café, com uma safra estimada em 50,45 milhões de sacas de 60 quilos em 2012 [9]. Nas lavouras cafeeiras é gerada uma quantidade de resíduos da ordem de $45 \%{ }^{[10]}$, o que torna a palha de café uma fonte de recurso natural, para um desenvolvimento energético sustentável.

No acompanhamento da estimativa da safra brasileira 2012, segundo a Conab (Companhia Nacional de Abastecimento), a produção nacional de café tem o estado de Minas Gerais como o campeão de produtividade, seguido pelo estado do Espírito Santo, São Paulo, Bahia, Paraná e o estado de Rondônia na sexta colocação, como mostrado na TAB.1. 
TABELA 1 - Maiores produtores de café no Brasil

\begin{tabular}{|c|c|c|}
\hline Colocação & Estado & Percentual \\
\hline $1^{0}$ & Minas Gerais & $52,80 \%$ \\
\hline $2^{0}$ & Espírito Santo & $24,21 \%$ \\
\hline $3^{0}$ & São Paulo & $9,99 \%$ \\
\hline $4^{0}$ & Bahia & $4,30 \%$ \\
\hline $5^{0}$ & Paraná & $3,37 \%$ \\
\hline $6^{0}$ & Rondônia & $3,25 \%$ \\
\hline
\end{tabular}

Fonte: Conab - Acompanhamento da safra brasileira - Café - Safra 2012 - Segunda estimativa http://www.conab.gov.br

Observada a produção brasileira da agricultura cafeeira, infere-se a ela uma grande quantidade de resíduos que podem ser utilizados para a geração de energia.

Aliada a essa cultura já consolidada no Brasil, ainda pode-se prever uma maior quantidade de geração residual da agricultura cafeeira, quando da determinação da Medida Provisória do novo Código Florestal baixada em maio/2012, que prevê o plantio de pés de café ao longo de áreas desmatadas por proprietários rurais, bem como ao longo das beiras de rios, consideradas Áreas de Preservação Permanente (APP) ${ }^{[11]}$.

Uma alternativa para evitar que tais resíduos sejam queimados no próprio campo onde são realizadas as colheitas, emitindo gases poluidores para a atmosfera, é usá-los como matéria-prima em um reator de pirólise para produção de energia.

O processo de pirólise consiste na decomposição da matéria orgânica em um sistema alotérmico, ou seja, por ação externa de calor, em ausência total ou parcial de oxigênio, em reator com trabalho a temperaturas inferiores a $900{ }^{\circ} \mathrm{C}$, 
tendo como produtos da reação gases tais como: o hidrogênio $\left(\mathrm{H}_{2}\right)$, o monóxido de carbono $(\mathrm{CO})$ e o metano $\left(\mathrm{CH}_{4}\right)$, um produto líquido denominado bio-óleo, e uma fração sólida denominada carvão ou cinzas ${ }^{[12]}$.

A FIG.1 representa um esquema do processo de pirólise de biomassa, no qual um reator de pirólise é alimentado pela biomassa, gerando gases, bioóleo e carvão.

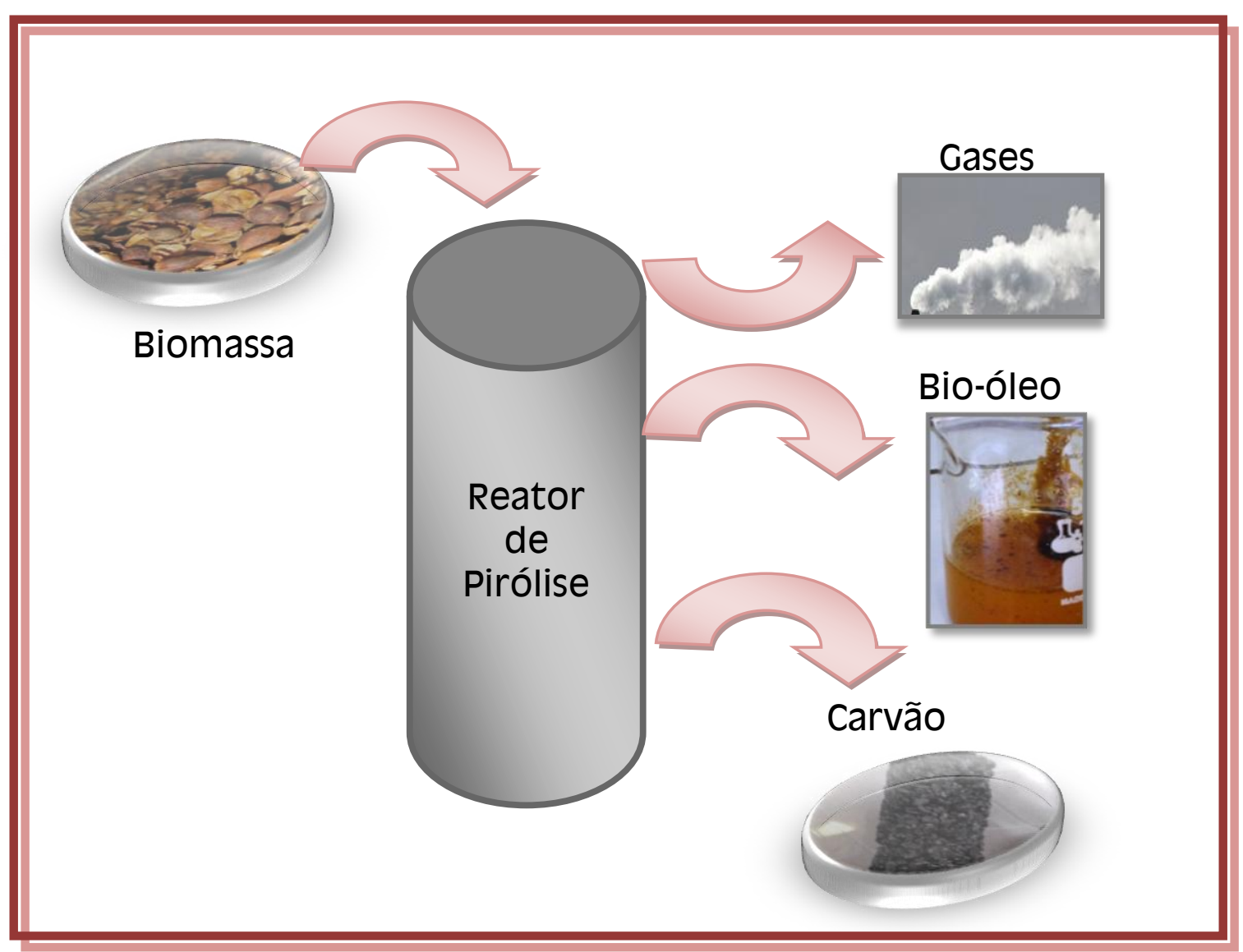

FIGURA 1 - Esquema representativo do processo da pirólise de biomassa.

Neste trabalho apresenta-se uma contribuição tecnológica aos processos de produção de hidrogênio, por meio de um processo de pirólise, com o estudo do comportamento da conversão da palha do café como fonte deste combustível. 
Avaliaram-se parâmetros como pressão de alimentação do gás de aquecimento, temperatura de operação e taxa de aquecimento durante o processo de pirólise, visando o melhor rendimento de hidrogênio na mistura gasosa obtida, para que se pudesse verificar a viabilidade da utilização deste gás em uma célula a combustível, para a geração de energia limpa. 


\section{OBJETIVO}

O presente trabalho visa o estudo do aproveitamento do resíduo da lavoura cafeeira como fonte de biomassa na obtenção de hidrogênio, por meio de um processo de pirólise. Visa-se, também, a avaliação do rendimento deste gás na mistura gasosa produzida, para estimar aplicações futuras em células a combustível, na geração de energia limpa. 


\section{REVISÃO DA LITERATURA}

\subsection{Energia e Meio Ambiente}

Diz a história, que no ano 900 da nossa era, os sábios chineses iluminaram alguns de seus templos com gás do solo, transportado em tubulações de bambu. Porém a tecnologia da conversão de material orgânico ou carbonífero em gás combustível teve origem somente nas últimas décadas do século XVII, na Inglaterra, quando John Clayton descobriu uma forma de produzir gás a partir da combustão do carvão, prendendo a "alma" da queima do carvão e "acendendo-a" dentro de um recipiente ${ }^{[13-15]}$. A partir daí, generalizou-se o uso de gás como meio de fonte luminosa, sendo distribuído por tubulações a residências e locais públicos. O processo utilizava um bico de gás protegido por um bulbo de vidro e a claridade era produzida pela incandescência de uma espécie de malha. Várias cidades foram iluminadas utilizando esse tipo de energia ao longo dos anos.

Com o advento da Revolução Industrial iniciada na Europa no século XVIII, enormes quantidades de carvão foram exumadas, com o objetivo de alimentar as então recém-inventadas máquinas a vapor ${ }^{[16]}$. O carvão acabou se revelando um recurso abundante, largamente empregado até hoje, apesar das preocupações por seu uso massivo, que incorreu como um dos agentes poluidores no que diz respeito às mudanças climáticas globais a partir de combustíveis fósseis.

Dentre os maiores produtores de carvão mineral da atualidade, a China se destacou com quase metade do percentual de produção mundial em 2010 (48,3\%), seguida pelos Estados Unidos (14,8\%), Austrália (6,3\%), Índia (5,8\%), Indonésia (5,0\%), Rússia (4,0\%), e África do Sul (3,8\%), mas a não observância em diversificar a matriz carbonífera, pode incorrer num esgotamento das jazidas, além dos fatores ambientais acima citados ${ }^{[17]}$. Na TAB.2, temos os valores dessa produção, em milhões de toneladas equivalentes de petróleo (Mtep), bem como os respectivos percentuais em relação à produção mundial. 
TABELA 2 - Produção de carvão mineral, em milhões de toneladas equivalentes de petróleo (Mtep), dos principais produtores mundiais em 2010

\begin{tabular}{lcc} 
País & Mtep & Percentual \\
& & \\
\hline China & 1800,4 & 48,3 \\
& \\
\hline Estados Unidos & 552,2 & 14,8
\end{tabular}

\begin{tabular}{lcc}
\hline Austrália & 235,4 & 6,3 \\
& \\
\hline Índia & 216,1 & 5,8
\end{tabular}

\begin{tabular}{lcc}
\hline Indonésia & 188,1 & 5,0 \\
& \\
\hline Rússia & 148,8 & 4,0
\end{tabular}

África do Sul $\quad 143,0 \quad 3,8$

Fonte: http://www.bp.com/statisticalreview

No início do século $X X$, com o advento da produção em escala industrial dos automóveis, começa a exploração e consumo do petróleo, bem como a recente utilização do gás natural, que foram e estão sendo utilizados até hoje tanto na produção de energia elétrica, como na utilização no aquecimento doméstico, industrial e como combustível para veículos automotores.

A dependência do homem moderno com relação à utilização cada vez mais acirrada dos hidrocarbonetos como sua fonte de energia primária, 
assinalou uma profunda mudança que trouxe consigo uma era sem precedentes de mudanças tecnológicas, socioeconômicas e culturais.

Os combustíveis fósseis como carvão, petróleo, gás natural e seus derivados suprem hoje, aproximadamente, $80 \%$ das necessidades mundiais de energia primária. $\mathrm{O}$ uso desses combustíveis impulsiona economias industrializadas tornando-se fundamental nas atividades produtivas da vida cotidiana no mundo moderno ${ }^{[18]}$.

O fato dos combustíveis fósseis terem sido utilizados à exaustão, uma vez que a população mundial cresceu sobremaneira, levou a emissão de poluentes a um nível muito maior do que o próprio planeta pudesse absorver, bem como reduziu suas jazidas naturais a um número bastante significativo, implicando numa geração de novos recursos e tecnologia de fornecimento energético.

Mesmo que o mundo continue, em larga escala, dependente do carvão, do petróleo e do gás natural, os primeiros elementos dessa transição começam a despontar.

Todos esses fatores, aliado ainda às queimadas a céu aberto de resíduos agrícolas, atividades agropastoris, lixões, aterros, desflorestamentos, etc., gerou uma quantidade significativa de gases de efeito estufa (GEE): gás carbônico $\left(\mathrm{CO}_{2}\right)$, ozônio $\left(\mathrm{O}_{3}\right)$, óxido nitroso $(\mathrm{NO})$, metano $\left(\mathrm{CH}_{4}\right)$, hexafluoreto de enxofre $\left(\mathrm{SF}_{6}\right)$, hidrofluorcarbonos (HFC) e perfluorcarbonos (PFC) ${ }^{[19-24]}$, que lançados na atmosfera, vêm provocando um deslocamento da temperatura do planeta, com uma estimativa de um acréscimo entre 1,4 e $5,8{ }^{\circ} \mathrm{C}$, para os próximos cem anos ${ }^{[25-26]}$.

Exemplo disso pode ser verificado por imagem divulgada pela NASA em 2007, de uma névoa de poluição particulada cobrindo parte da Ásia, entre a Coréia e o Japão conforme ilustrada na FIG.2. 


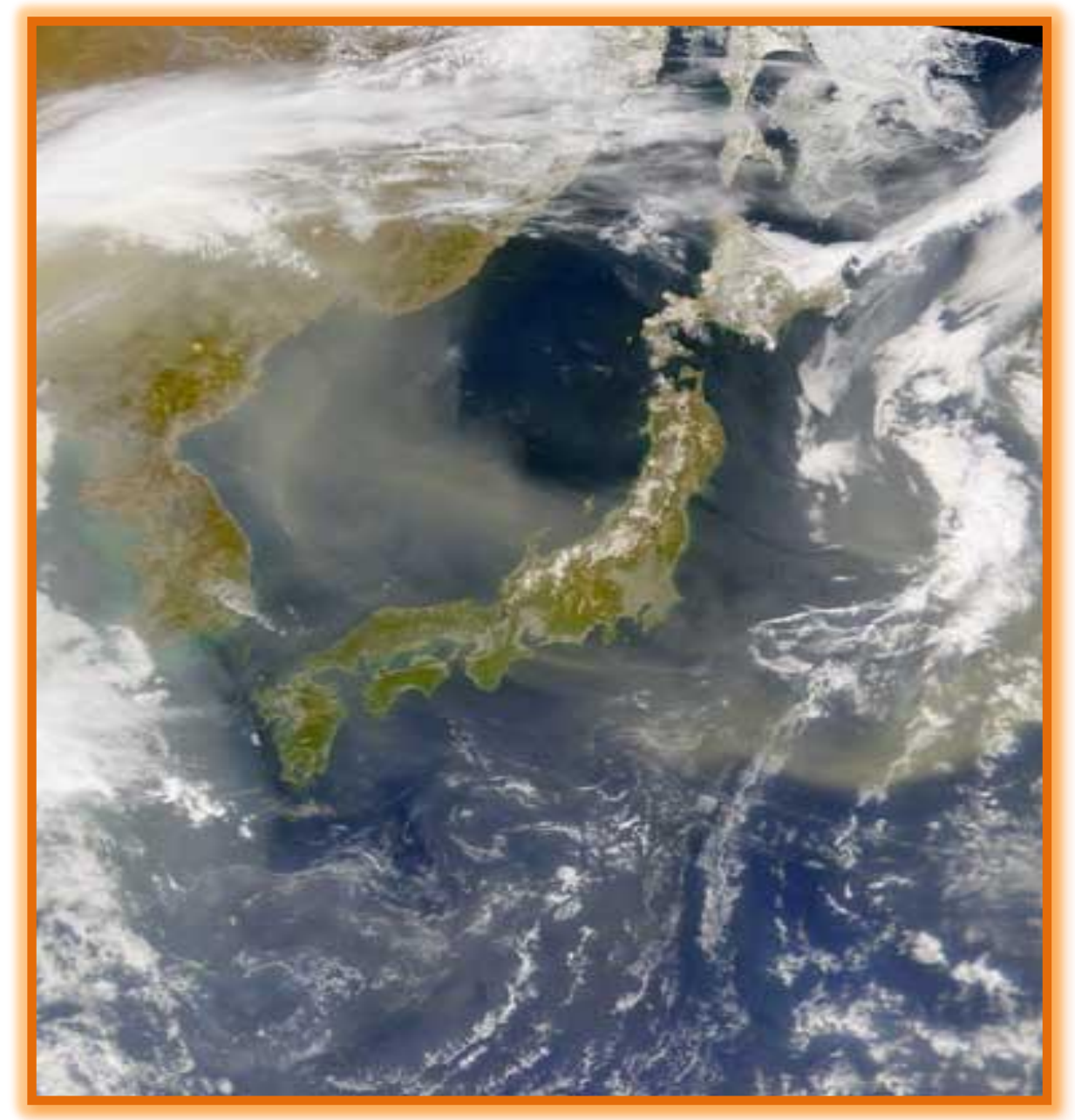

FIGURA 2 - Imagem de satélite mostra a nuvem de poluição particulada na Ásia, entre a Coréia e o Japão (Foto: NASA/Divulgação).

A nuvem de partículas em suspensão espalhada pelo continente asiático, que segundo estudos de pesquisadores liderados por Veerabhadran Ramanathan, do Instituto Scripps de Oceanografia (Califórnia, EUA), foi gerada por canos de escapamento, chaminés de fábricas e termelétricas, florestas e campos que estão sendo queimados para uso agrícola e madeira e esterco queimados como fonte de calor ${ }^{[27]}$.

A partir da década de 90, o fator ambiental avançou em importância dentro dos projetos de engenharia, sobretudo nos relacionados à geração de eletricidade.

Há de se destacar nesse processo a influência da Convenção-Quadro das Nações Unidas para as Mudanças Climáticas - CQNUMC, convenção 
negociada com o apoio das Nações Unidas, adotada durante a Eco92, evento acontecido no Rio de Janeiro - Brasil, onde se produziu um documento que reconheceu oficialmente as evidências de mudanças climáticas globais, causadas em grande parte pelo homem, e a gravidade da questão.

Neste documento foram propostas algumas ações e diretrizes de início ao combate do aquecimento global. Mais especificamente, a Eco92 teve como objetivo criar um compromisso de se reduzir as emissões de gases de efeito estufa (GEE), principalmente o dióxido de carbono $\left(\mathrm{CO}_{2}\right)$.

Para cumprir tal compromisso, instituiu-se uma Comissão Internacional com a responsabilidade de ministrar reuniões regulares anuais, as Conferencias das Partes (COP), onde seriam tomadas decisões em prol do avanço no combate às mudanças climáticas. Seriam também revistas as implementações da Convenção e examinados os compromissos das Partes, (países signatários), sobre os objetivos da Convenção, conforme as novas descobertas científicas e experiência adquirida no decorrer da implementação das políticas convencionadas.

Em 1997, na terceira reunião da Comissão em Quioto, no Japão, um protocolo foi apresentado com propostas concretas para o início do processo de redução das emissões às partes signatárias da Convenção. O Protocolo de Quioto estabeleceu a necessidade de redução de emissão em 5,2\% no período de 2008 a 2012, com base nas emissões do ano de 1990. Neste protocolo, foram propostos três mecanismos de flexibilização - a Implementação Conjunta, o Comércio de Emissões e o Mecanismo de Desenvolvimento Limpo, que facilitariam as vias econômicas do compromisso de redução das emissões de gases do efeito estufa (GEE).

A Implementação Conjunta é um dos mecanismos de flexibilização do Protocolo de Quioto criado com o objetivo de ajudar os países a cumprirem metas de redução de gases do efeito estufa (GEE).

Esse mecanismo, definido no Artigo 6 do referido protocolo, permite a um país que possui limites de emissões de GEE desenvolver um projeto de remoção de emissões em outro país cuja economia seja de transição, ficando assim com os créditos de carbono, aqui chamados de Unidades de emissão Reduzida (ERUs - Emisssion Reduction Units) ${ }^{[28]}$. 
Assim, a Implementação Conjunta oferece às Partes, um meio flexível de custo - eficiência para o cumprimento de seus compromissos com o Protocolo, onde os países que investem podem economizar, focando em locais onde os custos são menores, enquanto que os que hospedam os projetos se beneficiam com os investimentos estrangeiros e transferências de tecnologias ${ }^{[29]}$.

O Comércio das Emissões é um mecanismo de flexibilização previsto no Artigo 17 do Protocolo de Quioto pelo qual os países compromissados com a redução dos gases de efeito estufa (GEE) podem negociar o excedente das metas de emissões entre si, vendendo esse excesso de capacidade para os países que estão buscando o cumprimento de suas metas.

Um dos projetos mais bem implementados do gênero encontra-se na Europa e tem o nome de Regime Comunitário de Licenças de Emissão da União Europeia.

O MDL é um dos instrumentos de flexibilização estabelecido pelo Protocolo de Quioto com o objetivo de facilitar o alcance das metas de redução de emissão de gases de efeito estufa definidas para os países que o ratificaram. Em síntese, a proposta do MDL (descrita no Artigo 12 do Protocolo) consiste em que cada tonelada de $\mathrm{CO}_{2}$ equivalente $\left(\mathrm{tCO}_{2} \mathrm{e}\right)$ que deixar de ser emitida ou for retirada da atmosfera por um país em desenvolvimento poderá ser negociada no mercado mundial, criando novo atrativo para a redução das emissões globais ${ }^{[30]}$.

$\mathrm{O} \mathrm{CO}_{2}$ equivalente é o resultado da multiplicação das toneladas emitidas do GEE pelo seu potencial de aquecimento global. Existem parâmetros científicos pré-estabelecidos para se calcular quantos créditos de carbono foram gerados por um projeto. Há um fator para cada combustível fóssil e poluente que deixa de ser emitido. Os valores definidos pelo IPCC (Painel Intergovernamental de Mudanças Climáticas), órgão que auxilia os países membros do Protocolo de Quioto, determinou que o potencial de aquecimento global do $\mathrm{CO}_{2}$ fosse estipulado com o valor unitário 1. O potencial de aquecimento global do gás metano foi definido como sendo 21 vezes maior do que o potencial do $\mathrm{CO}_{2}$, portanto $\mathrm{O}_{\mathrm{CO}_{2}}$ equivalente do metano é igual a 21, ou seja, uma tonelada de metano reduzida corresponde a 21 créditos de carbono. Na TAB 3, temos os fatores de conversão do potencial de aquecimento global dos gases do esfeito estufa (GEE), segundo o IPCC ${ }^{[31]}$, para os cálculos correspondentes aos créditos de carbono, quando da não emissão de tais poluentes. 
TABELA 3 - Fator do potencial de aquecimento global dos GEE

\begin{tabular}{|c|c|c|}
\hline $\mathrm{CO}_{2}$ & Dióxido de Carbono & 1 \\
\hline $\mathrm{CH}_{4}$ & Metano & 21 \\
\hline $\mathrm{N}_{2} \mathrm{O}$ & Óxido nitroso & 310 \\
\hline HFCs & Hidrofluorcarbonetos & $140 \sim 11700$ \\
\hline PFCs & Perfluorcarbonetos & $6500 \sim 9200$ \\
\hline $\mathrm{SF}_{6}$ & Hexafluoreto de enxofre & 23900 \\
\hline
\end{tabular}

Fonte: Adaptado IPCC 2007

Ao longo dos anos, os sistemas elétricos tornaram-se cada vez mais centralizados. Grandes centrais de produção de eletricidade justificavam sobre os custos de geração e do fator escala, a inexistência de restrições maiores com relação aos impactos ambientais e em função do próprio modelo de organização empresarial que imperou no setor durante anos. Entretanto, a partir do final da segunda metade dos anos 70, o setor elétrico entrou em uma nova fase em vários países. A elevação dos custos de geração segundo tecnologias convencionais e o processo recessivo nos países industrializados, causados pelo segundo choque na crise do petróleo, aceleraram as reformas institucionais do setor.

Essas reformas, de caráter descentralizador, levaram à definição de um maior espaço para a cogeração, à produção elétrica em pequena escala, ao uso mais intensivo de fontes energéticas renováveis e à produção independente. As principais características desse novo padrão de expansão no setor elétrico fizeram eco às pressões sociais em relação à minimização dos impactos ambientais, à necessidade de uso mais racional de insumos energéticos e ao crescente questionamento do papel exercido pelos Estados na detenção da infraestrutura energética.

Dentro do contexto de reformas, a iniciativa mais marcante foi a criação do Public Utility Regulatory Polity Act (PURPA), em 1978, nos EUA. O PURPA, 
que vigorou até 1983 na forma como foi originalmente concebido, criou espaço institucional para a expansão da cogeração e para o crescimento de geração elétrica a partir de fontes energéticas renováveis. Com o mesmo espírito e, inclusive, usando a experiência norte americana como principal referência, vários outros programas do gênero foram definidos em países europeus e no Japão em anos subsequentes.

No Brasil, o PROINFA - Programa de Incentivo às Fontes Alternativas de Energia - regulamentado em 2004 pelo governo federal, representou uma iniciativa relevante na definição de uma política estrutural para as energias alternativas renováveis. Este programa está em conformidade com os objetivos da Política Energética Nacional, dentre os quais se destacam a diversificação da matriz energética brasileira e a busca de soluções de cunho regional, com a utilização de fontes renováveis de energia mediante o aproveitamento econômico dos insumos disponíveis e das tecnologias aplicáveis ${ }^{[32]}$.

Mais recentemente, a produção de energia elétrica a partir da biomassa tem sido defendida como uma importante opção para os países em desenvolvimento e mesmo para os países europeus. A questão ambiental, com a necessidade de minimização das emissões globais de $\mathrm{CO}_{2}$, é o ponto comum de ambas as propostas.

Um ranking que compara o mercado energético de 40 países, levando em consideração sua infraestrutura e adequação às tecnologias de ponta na área de energias renováveis em 2011, exibe um panorama do que vem se tornando o setor, como mostrado na FIG. $3^{[33]}$. 


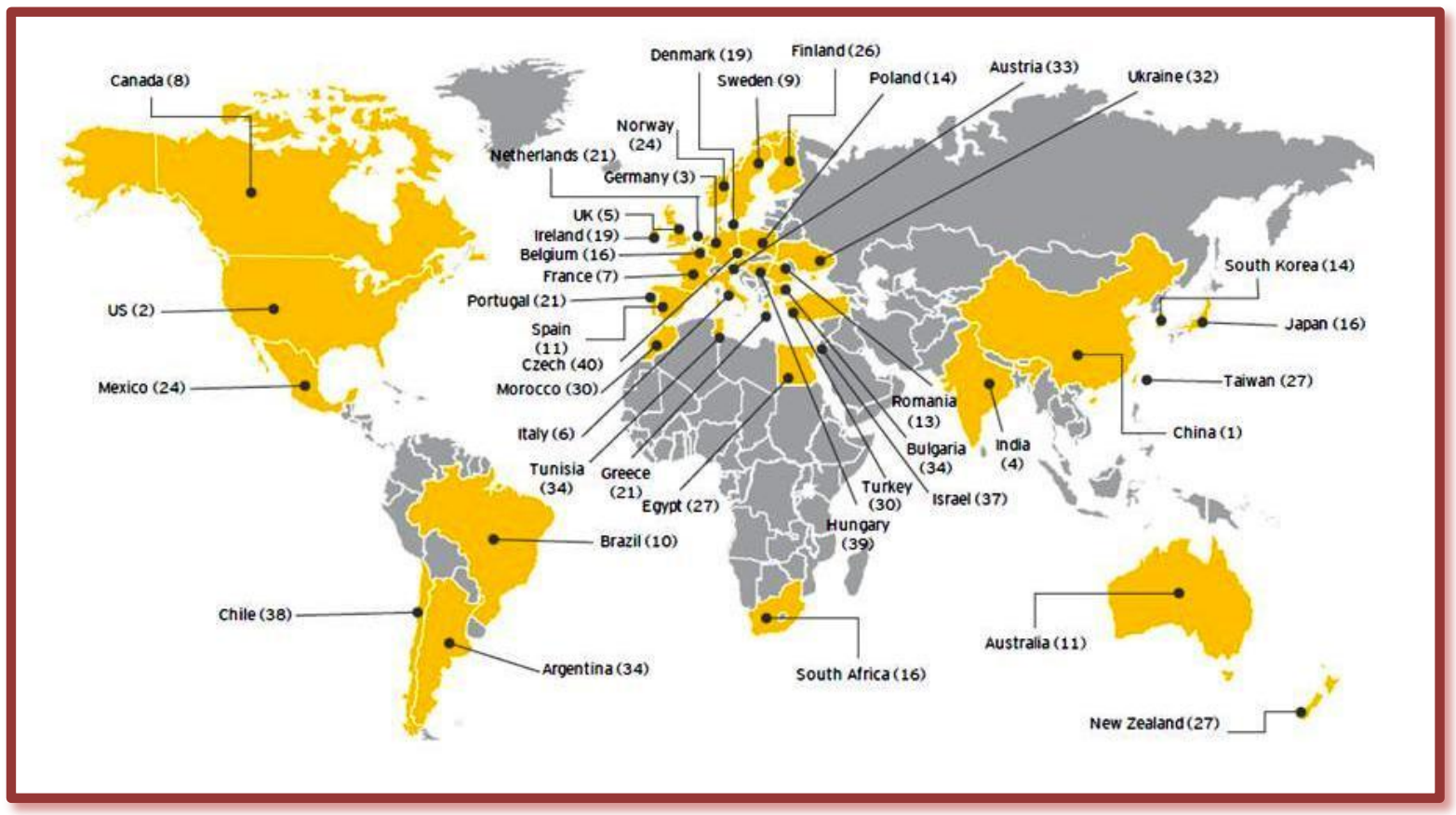

FIGURA 3 - Ranking de países com melhor infraestrutura e adequação tecnológica em energia renovável em 2011.

O Brasil garantiu mais uma vez seu posicionamento entre os 10 países com cenário favorável à energia renovável, ficando pelo segundo ano consecutivo na décima posição.

A China continua à frente, garantindo o melhor desempenho, seguida pelos Estados Unidos na segunda colocação, por conta do acréscimo em potencial da capacidade da indústria eólica em 2011.

$\mathrm{Na}$ Alemanha, o esforço para eliminar a energia nuclear fez com que novos projetos fossem financiados, o que resultou em uma expansão em energia limpa, garantindo o terceiro lugar. A Índia por sua vez, conseguiu o quarto lugar, com investimentos em geração solar.

O Reino Unido ocupando a quinta colocação com um projeto que está entre os maiores do mundo em energia eólica, conta também com os aportes em biomassa.

Como se pode observar a partir dos dados citados, há uma enorme movimentação mundial no que se refere à utilização de energias renováveis levando-se em consideração as melhores opções segundo as riquezas naturais, 
bem como as tecnologias desenvolvidas, que melhor atendem cada região do planeta.

Por energias renováveis, entendem-se aquelas obtidas de fontes naturais capazes de regeneração e, portanto, ditas "inesgotáveis" [34] em contra ponto às energias não renováveis, que apesar de serem encontradas na natureza, são passíveis de esgotamento quando da utilização massiva de suas jazidas.

As energias renováveis são consideradas como "energias alternativas", quando comparadas ao modelo energético tradicional, tanto pela disponibilidade presente e futura garantida, quanto pelo seu menor impacto ambiental ${ }^{[35]}$.

Podemos citar como alguns exemplos de energias renováveis: a energia hídrica, eólica, solar, geotérmica, das marés, das ondas e da biomassa, como ilustrado na FIG.4.

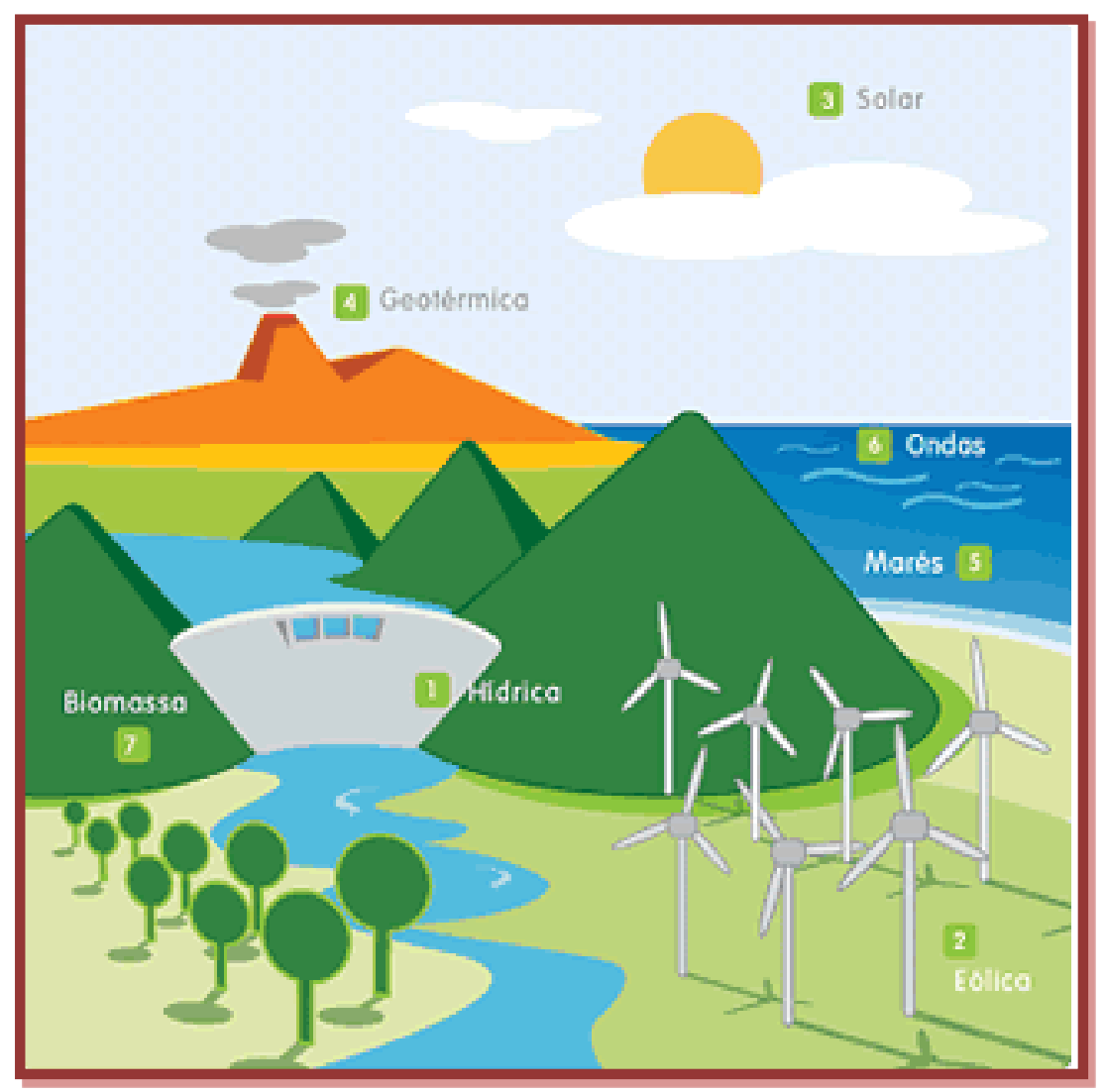

FIGURA 4 - Fontes de energia renováveis.

Fonte: http://geoamb.wordpress.com 
Dentre as fontes de energia renováveis, matérias primas a partir da biomassa têm sido bastante promissoras, onde pode-se notar uma evolução significativa na capacidade instalada de usinas térmicas, por exemplo, como mostrado na FIG.5 ${ }^{[36]}$.

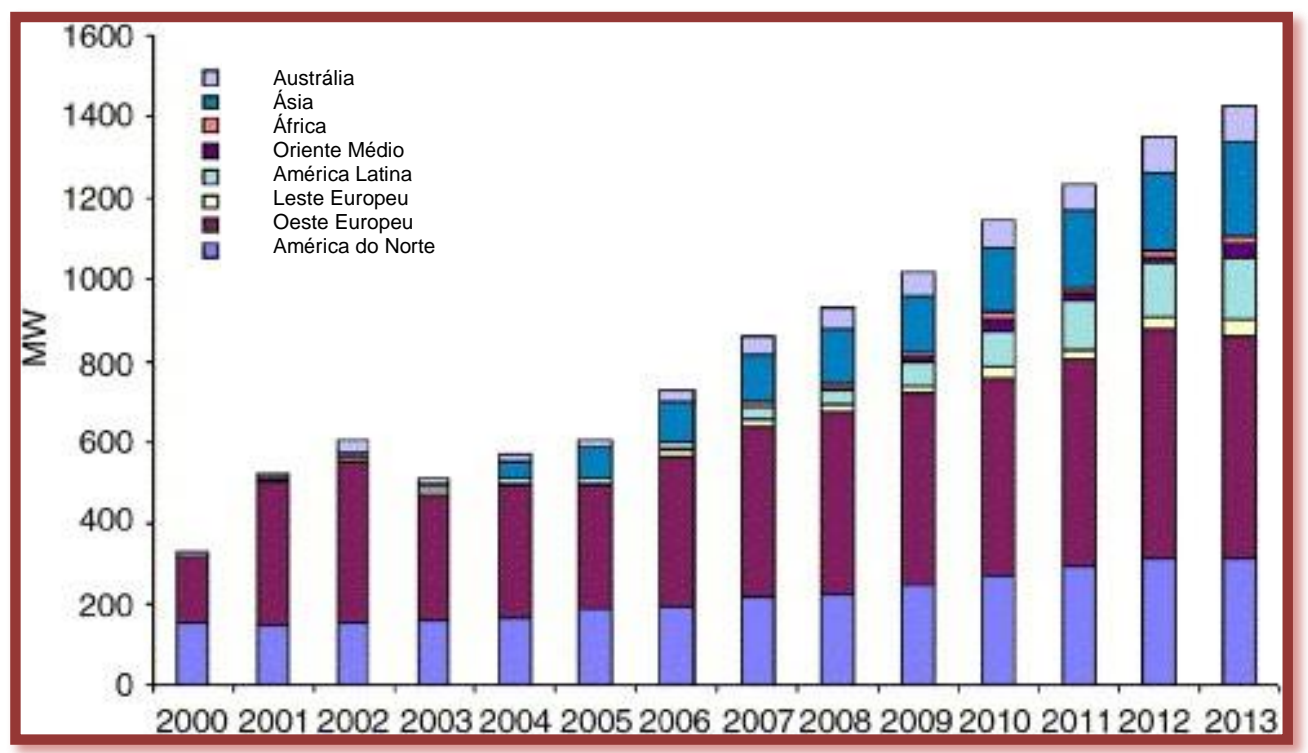

FIGURA 5 - Capacidade anual instalada de usinas térmicas à biomassa no mundo com previsão para 2013.

O Brasil dispõe de uma extensa variedade de culturas florestais e agrícolas, com resíduos gerados a partir da sua colheita, beneficiamento e processamento, o que coloca a utilização da biomassa como fonte de energia elétrica num crescente aproveitamento, principalmente em sistemas de cogeração, pela qual é possível obter energia elétrica e térmica nos setores industrial e de serviços.

Em 2007, a biomassa foi responsável pela oferta de $18 \mathrm{TWh}$, segundo o Balanço Energético Nacional (BEN) de 2008. Esse volume foi $21 \%$ superior ao de 2006 e ao corresponder a 3,7\% da oferta total de energia elétrica, obteve uma posição de destaque na matriz elétrica nacional, conforme a FIG. ${ }^{[37]}$. 


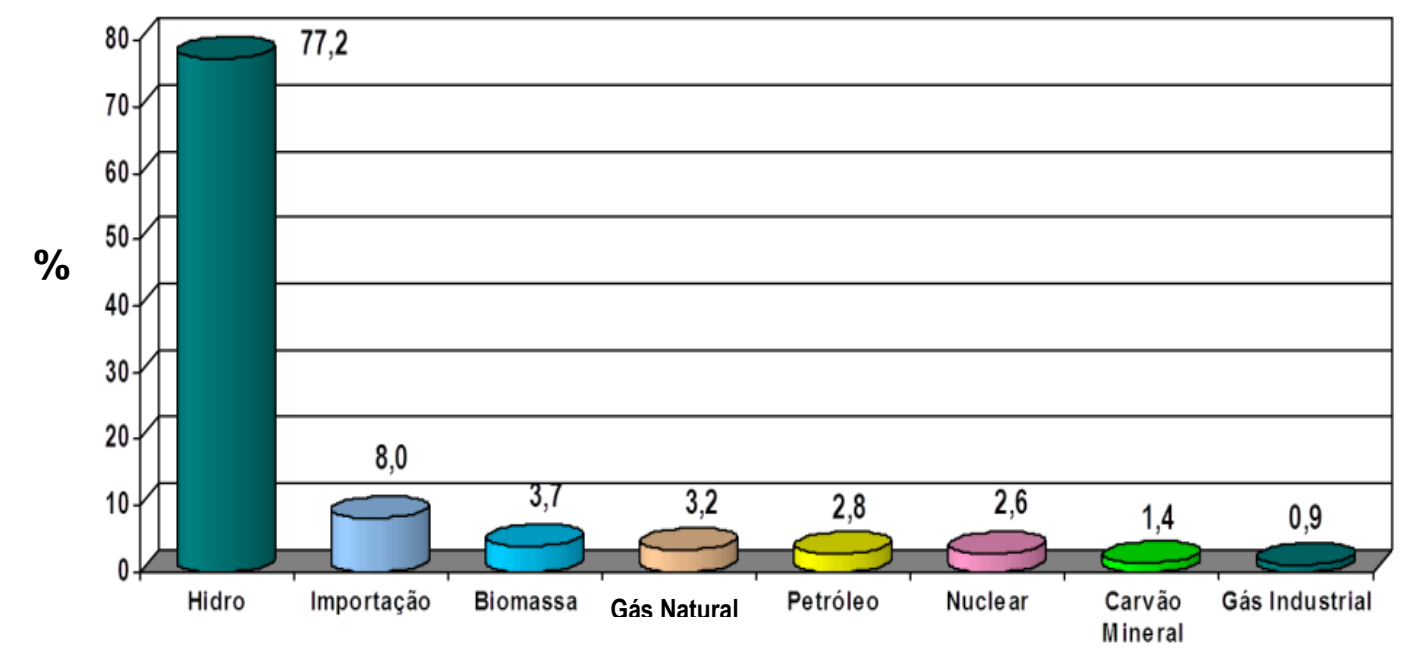

FIGURA 6 - Matriz de oferta de energia elétrica do Brasil - 2007 (\%).

Fonte: MME/ BEN (2008)

A crescente preocupação da sociedade com questões ambientais deve influir nas decisões dos dirigentes quanto às possibilidades de utilização das fontes energéticas. Dentro desse aspecto, os combustíveis fósseis são os mais criticados, devido à produção de uma quantidade de $\mathrm{CO}_{2}$ que o planeta não tem condições de assimilar em longo prazo e também pela possibilidade de emissão de óxidos de enxofre e nitrogênio, emitidos na queima de combustíveis em veículos e indústrias.

Anualmente, a Agência de Informações de Energia do Departamento de Energia dos Estados Unidos (EIA/DOE) atualiza seu cenário prospectivo de oferta e demanda global de energia. A partir de dados agregados é possível inferir comportamentos do mercado mundial, como por exemplo, o crescimento sustentado das energias renováveis.

Em um estudo liberado em 2010, a utilização de energias renováveis para geração de eletricidade de 2007 a 2035, terá um crescimento médio de 3\% ao ano, como mostrado na FIG.7, onde se inclui nessa prospecção a cogeração com usinas de cana de açúcar e as termoelétricas a biomassa no Brasil. 


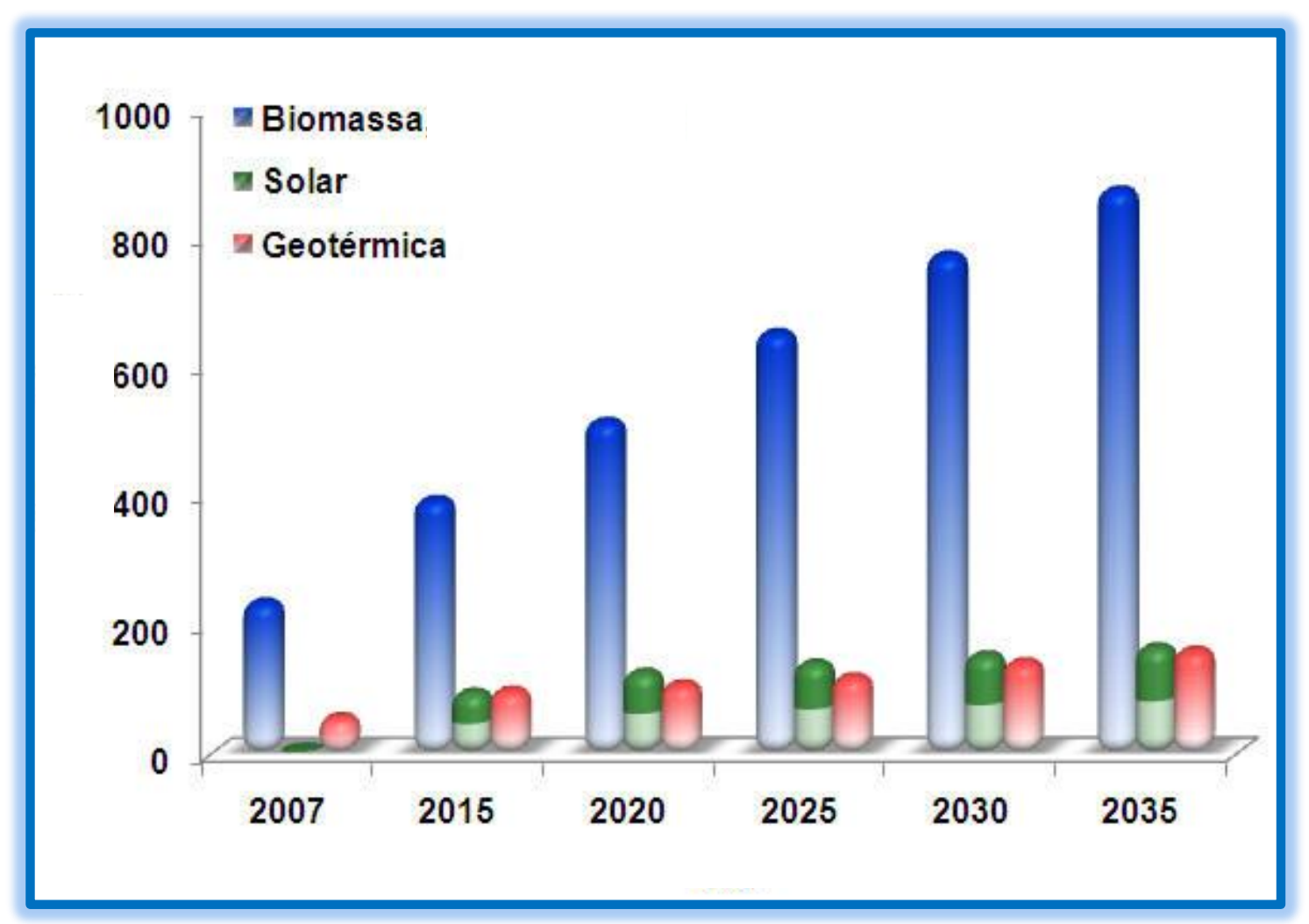

FIGURA 7 - Geração de eletricidade por fontes renováveis.

Fonte: http://infousa.state.gov

Numa prospecção em longo prazo, as fontes renováveis poderão suprir $80 \%$ da energia em 2050, sendo que a biomassa, a energia eólica e a energia solar serão, dentre as renováveis, as que mais estarão contribuindo para a oferta de energia no mundo em 40 anos. Essas foram as principais conclusões do Relatório Especial sobre Energias Renováveis divulgadas pelo Intergovernmental Panel on Climate Change (IPCC), o painel da ONU que estudou a mudança climática, no mês de maio de 2012, em reunião realizada em Abu Dhabi. De acordo com os cenários analisados pelo IPCC, as fontes renováveis poderão reduzir entre $220 \mathrm{Gt}$ e $560 \mathrm{Gt}$ (gigatoneladas) a emissão de $\mathrm{CO}_{2}$ na atmosfera entre 2010 e 2050, tendo na biomassa uma alta expectativa de crescimento quanto a utilização para aquecimento e eletricidade, como mostra a FIG.8. 


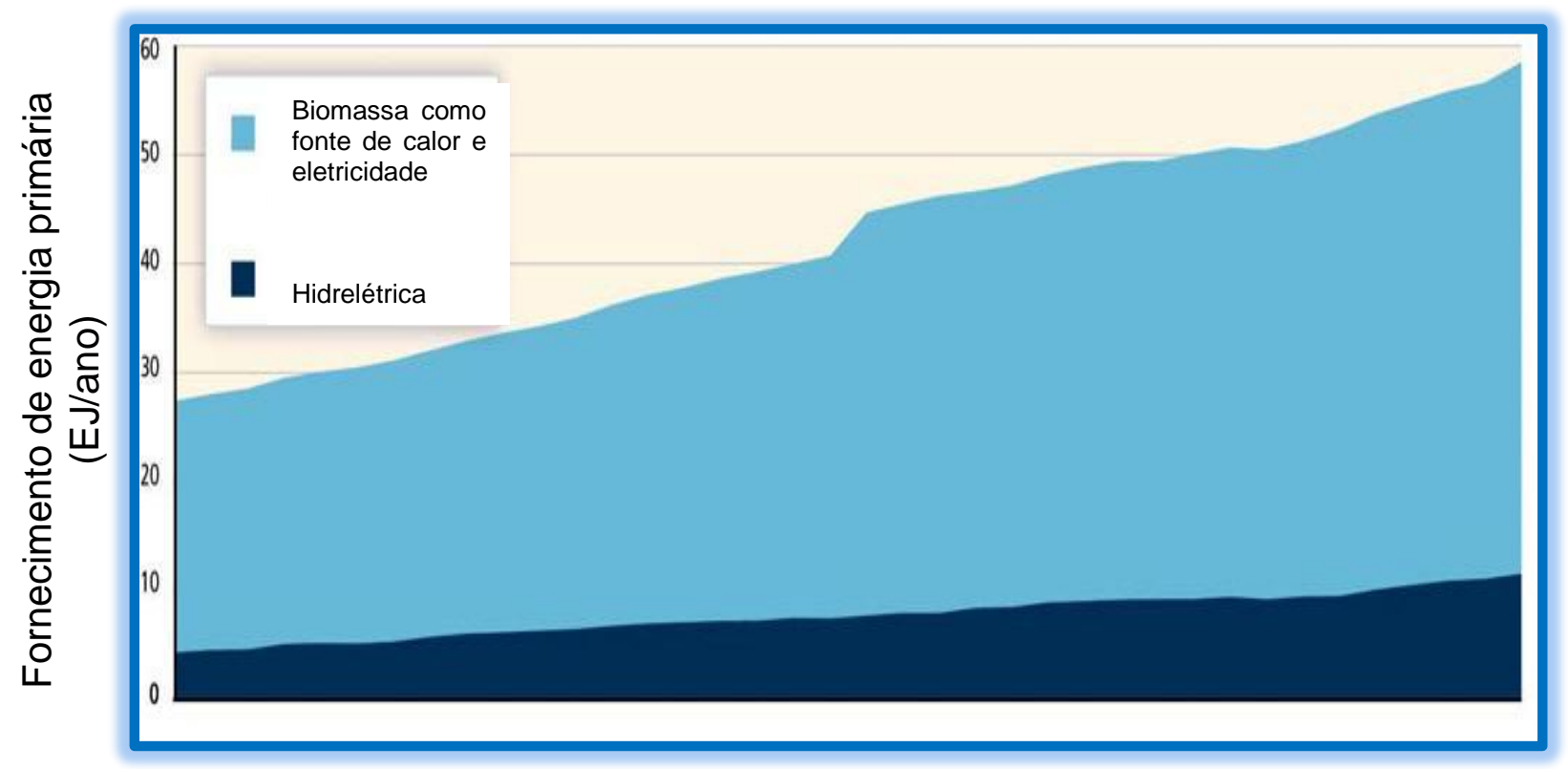

FIGURA 8 - Prospecção da utilização da biomassa como fonte para geração de aquecimento e eletricidade.

Fonte: IPCC 2012

Deve-se considerar que todo petróleo e o carvão disponível será certamente um dia utilizado. Suas aplicações podem gerar energia ou produzir materiais plásticos. Estes podem ser reciclados, o que não acarretaria grande impacto ambiental ${ }^{[38]}$, uma vez que um dos grandes problemas das energias fósseis é a liberação do $\mathrm{CO}_{2}$ na atmosfera.

A utilização da biomassa para geração de energia também pode gerar $\mathrm{CO}_{2}$, mas esta biomassa é oriunda de plantas que consumiram, durante seu crescimento, exatamente a mesma quantidade desse gás que será devolvida à atmosfera após seu uso final. Como esta opção só faz sentido ao se considerar uma área cultivada onde estão crescendo continuamente plantas que virão a produzir a energia de que a sociedade necessita, o balanço de $\mathrm{CO}_{2}$ é continuamente nulo, não afetando o efeito estufa, o que torna a biomassa "carbonicamente neutra" ${ }^{[14]}$, como mostrado na FIG.9. 


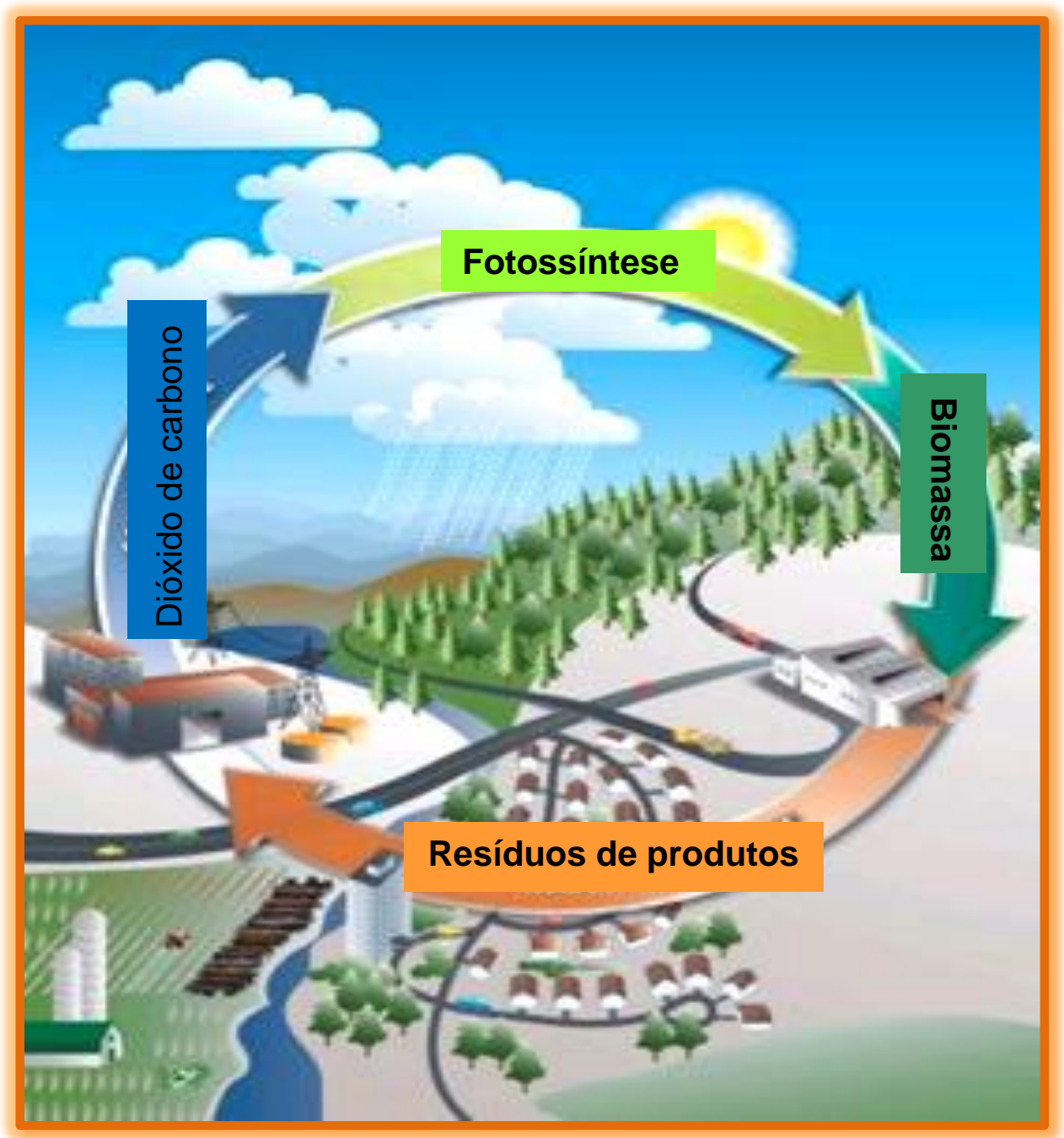

FIGURA 9 - Ciclo "carbonicamente neutro" da biomassa.

Fonte: http://ashera0008.multiply.com/journal/item/28/Energia da Biomassa

\subsection{Biomassa}

Temos como definição de biomassa, todo material orgânico que está disponível em uma base renovável ou recorrente, incluindo colheitas de agricultura e árvores, madeira e resíduos, plantas (incluindo as aquáticas), fibras e dejetos animais, detritos municipais e outros rejeitos orgânicos ${ }^{\text {[39] }}$.

Do ponto de vista energético, biomassa é toda matéria orgânica, de origem animal ou vegetal, que pode ser utilizada na produção de energia.

As plantas comportam-se como verdadeiras usinas, transformando a energia eletromagnética do Sol em energia química. As folhas contêm moléculas 
de dióxido de carbono $\left(\mathrm{CO}_{2}\right)$, absorvidas por elas diretamente do ar, assim como moléculas de água $\left(\mathrm{H}_{2} \mathrm{O}\right)$, absorvidas pelas raízes e conduzidas em toda sua extensão em complexo processo, inicialmente por osmose e depois por capilaridade, controlado via mecanismos de respiração. Essas moléculas podem ser combinadas se houver energia disponível para provocar uma reação química endotérmica (com captação de calor solar).

Essa energia, afortunadamente, está disponível vinda do Sol, em abundância nos trópicos, sob a forma de fótons. Do espectro radiativo solar as folhas absorvem o azul e o vermelho e refletem o verde, daí a cor verde das folhas. Os fótons do vermelho (parte calorífica do espectro solar) são então absorvidos pela clorofila, que é um pigmento presente em células próximas à superfície das folhas. A clorofila acumula, assim, energia necessária para quebrar a molécula de $\mathrm{CO}_{2}$ e fazer o carbono interagir com a água, com a seguinte reação química básica :

$$
\text { fóton }+\mathrm{CO}_{2}+\mathrm{H}_{2} \mathrm{O} \Longrightarrow\left(\mathrm{CH}_{2} \mathrm{O}\right)+\mathrm{O}_{2}
$$

O oxigênio liberado pela fotossíntese é lançado para atmosfera, sendo depois parcialmente consumido pela respiração.

$\mathrm{CH}_{2} \mathrm{O}$ não é propriamente uma molécula, mas um agrupamento de átomos que constitui a base para a formação das moléculas orgânicas chamadas de hidratos de carbono.

A mais simples dessas moléculas é a glicose, uma forma de açúcar, formada pela reação:

$$
\text { fóton }+6 \mathrm{CO}_{2}+6 \mathrm{H}_{2} \mathrm{O} \Longrightarrow \mathrm{C}_{6} \mathrm{H}_{12} \mathrm{O}_{6}(\text { glicose })+6 \mathrm{O}_{2}
$$

A produção de hidratos de carbono por todas as plantas chega a mais de 150 bilhões de toneladas por ano. Essa fantástica soma é 150 vezes maior que a produção mundial de cimento e aço.

A partir dos hidratos de carbono resultantes do processo fotossintético, sucede-se a formação de outros compostos químicos derivados de processos metabólicos próprios da fisiologia dos vegetais. Assim, além dos hidratos de 
carbono, outros compostos químicos podem ser produzidos e armazenados nas plantas, em particular lipídios (óleos vegetais) e proteínas ${ }^{[8]}$.

Quanto ao aproveitamento energético especificamente da biomassa vegetal, podemos classificá-las como: Sacarídeos (cana-de-açúcar, caule de sorgo, beterraba, etc.); Celulósicos (gramíneas, rejeitos florestais, bagaço de cana, casca de arroz, etc.); Amiláceos (mandioca, milho, batata, etc.); Triglicerídeos ou Oleaginosas (dendê, copaíba, amendoim, soja, algodão, mamona, etc.); Aquáticas; Madeiras; Resíduos agropecuário, urbanos e agroindustriais ${ }^{[40]}$. Na FIG.10 apresenta-se um fluxograma das diferentes fontes de biomassa.

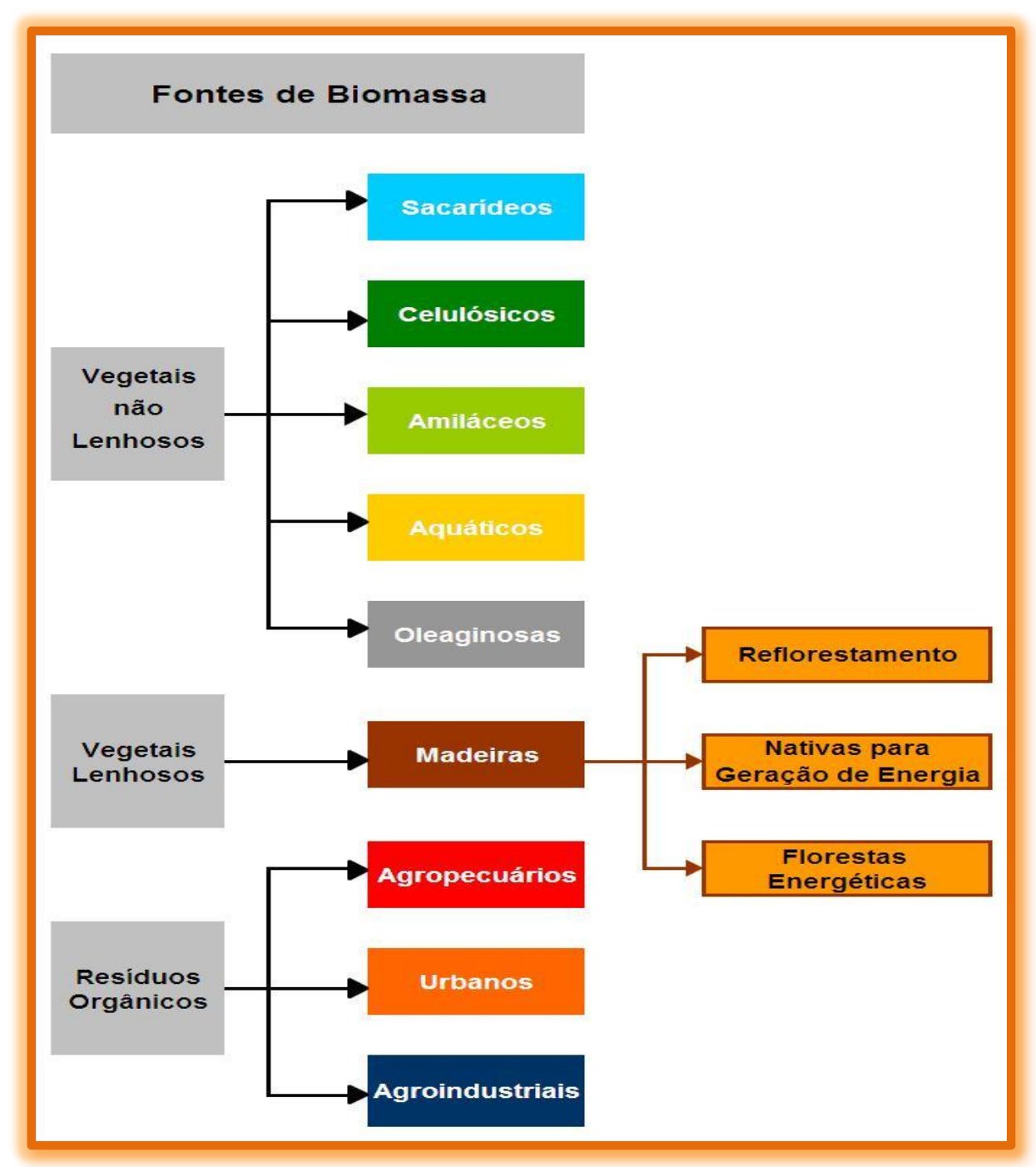

FIGURA 10 - Fluxograma das diferentes fontes de biomassa.

Fonte: Adaptado Cenbio, 2009 
Ainda que grande parte da biomassa seja de difícil contabilização, estima-se que ela represente cerca de $14 \%$ de todo o consumo mundial de energia primária. Nos países em desenvolvimento, essa parcela aumenta para $34 \%$, chegando a $60 \%$ na África, como apresentado na TAB.4.

TABELA 4 - Consumo mundial de energia primária (Mtep)

\begin{tabular}{|c|c|c|c|c|}
\hline Pás ou Regiala & Biomassa [1] & Outros & Total [2] & {$[112] \%$} \\
\hline Mundial & 930 & 5.713 & 6.643 & 14 \\
\hline China & 206 & 649 & 855 & 24 \\
\hline Leste Asiádico & 106 & 316 & 422 & 25 \\
\hline Sul da Asia & 235 & 188 & 423 & 56 \\
\hline América Latina & 73 & 342 & 415 & 18 \\
\hline Africa & 205 & 136 & 341 & 60 \\
\hline Palses em desenvolinimento & 825 & 1.632 & 2.457 & 34 \\
\hline Paises da OCDE & 81 & 3.044 & 3.125 & 3 \\
\hline
\end{tabular}

Fonte: Atlas de Energia Elétrica do Brasil, 2005.

Diversos materiais como restos de colheita e lavouras, ou mesmo sobras de produtos processados no ambiente rural, são dispostos de modo inadequado, causando problemas que vão desde a poluição e degradação dos solos e águas, facilitando a proliferação de vetores de doenças, ao seu não aproveitamento total como fonte de renda extra, servindo como matéria prima para outros produtos.

Não obstante, uma grande parte da matéria orgânica residual é tratada inadequadamente, contribuindo de forma indesejável para as mudanças na biosfera, principalmente em países de baixa renda onde a reutilização de resíduos orgânicos não se constitui prática comum, enquanto que grandes quantidades desses produtos são queimadas nos campos, ou usadas como combustível doméstico. 
Parafraseando Vasconcellos ${ }^{[8]}$ : "Se o Sol é o imenso reator energético, então a terra do sol passa a ser o lócus por excelência da energia armazenada. De onde se conclui que o Brasil, o continente dos trópicos, é o lugar da energia verde. Energia vegetal. Terra da biomassa. Terra da energia".

Muitos países já entraram na corrida energética, fazendo levantamentos bem como se prevalecendo de tecnologias conhecidas para a utilização de suas fontes naturais. Esse interesse deve ser creditado à conjunção de vários fatores, tais como:

a produção de eletricidade a partir da biomassa tem um ciclo de Carbono praticamente fechado, as emissões de $\mathrm{SO}_{x}$ são muito pequenas, ou nulas e têmse menos cinza residual do que quando se utiliza o carvão mineral, por exemplo;

alguns analistas acreditam que é no uso energético de resíduos que vai ser definido o maior mercado, nos países desenvolvidos, dessas novas tecnologias de conversão de biomassa. Esta tendência será tanto mais forte quanto maior a pressão da sociedade;

a conveniência da redução da dependência de alguns países com relação aos combustíveis fósseis e, em especial aos derivados de petróleo, deve aumentar a procura no desenvolvimento de energias de fontes renováveis.

Em associação aos pontos acima listados, identificou-se um certo número de oportunidades de curto e médio prazo que podem facilitar o maior uso da biomassa na geração de energia elétrica. São eles:

algumas termoelétricas e várias caldeiras industriais que hoje queimam carvão mineral deverão ser substituídas ou reformadas nos próximos anos, o que define uma janela de oportunidade para a conversão parcial dessas instalações para a queima conjunta da biomassa;

especialistas do setor elétrico consideram que sistemas híbridos de produção de eletricidade, que façam queima conjunta, por exemplo, de biomassa e gás natural, oferecem baixíssimo risco;

em alguns segmentos industriais que fazem uso intensivo de biomassa, enquanto matéria prima e energia, existe um grande potencial para a produção de eletricidade a partir, por exemplo, de resíduos do processo ${ }^{[41]}$.

Como a biomassa é um recurso renovável que pode atingir emissões de carbono baixas ou quase nulas, desde que tecnologias apropriadas de conversão sejam usadas e as matérias primas utilizadas sejam geridas de forma 
sustentável, considera-se que a maior dependência da biomassa em aplicações modernas possa desempenhar um papel importante na transição para sistemas energéticos mais sustentáveis.

A biomassa, portanto, merece atenção especial porque, a curto e médio prazo, oferece as alternativas mais promissoras aos combustíveis líquidos à base de petróleo no setor de transporte, bem como fornecimento de energia para as zonas rurais, melhorando ou substituindo métodos tradicionais de utilização de energia de biomassa com, por exemplo, a queima direta pela utilização de biogás em fogões domésticos, a iluminação a partir da alimentação de geradores por bio-óleo, etc., com consequentes benefícios para a saúde humana e para a preservação da natureza.

Usos modernos da biomassa oferecem um leque bastante amplo de possibilidades para reduzir a dependência de combustíveis fósseis, diminuir emissões de gases do efeito estufa e promover desenvolvimento econômico sustentável.

No Brasil, a imensa superfície do território nacional, quase toda localizada em regiões tropicais e chuvosas, oferece excelentes condições para a produção e o uso energético da biomassa em larga escala. Além da produção de álcool, queima em fornos, caldeiras e outros usos não comerciais, a biomassa apresenta grande potencial no setor de geração de energia elétrica.

Incentivos quanto à utilização da biomassa no Brasil tem sido bastante promissoras, incluído legislação que versa sobre empreendimentos condizentes às energias renováveis, como instituído pela Lei $n^{\circ} 10.438$, de 26.04.02, “... com o objetivo de aumentar a participação da energia elétrica produzida por empreendimentos... concebidos com base em fontes eólica, pequenas centrais hidrelétrica e biomassa, no Sistema Interligado Brasileiro,..." ${ }^{[42]}$.

Na FIG.11 temos um panorama da oferta interna de energia elétrica no Brasil, dividido pelas diversas fontes da qual o país faz uso para geração eletricitária. 


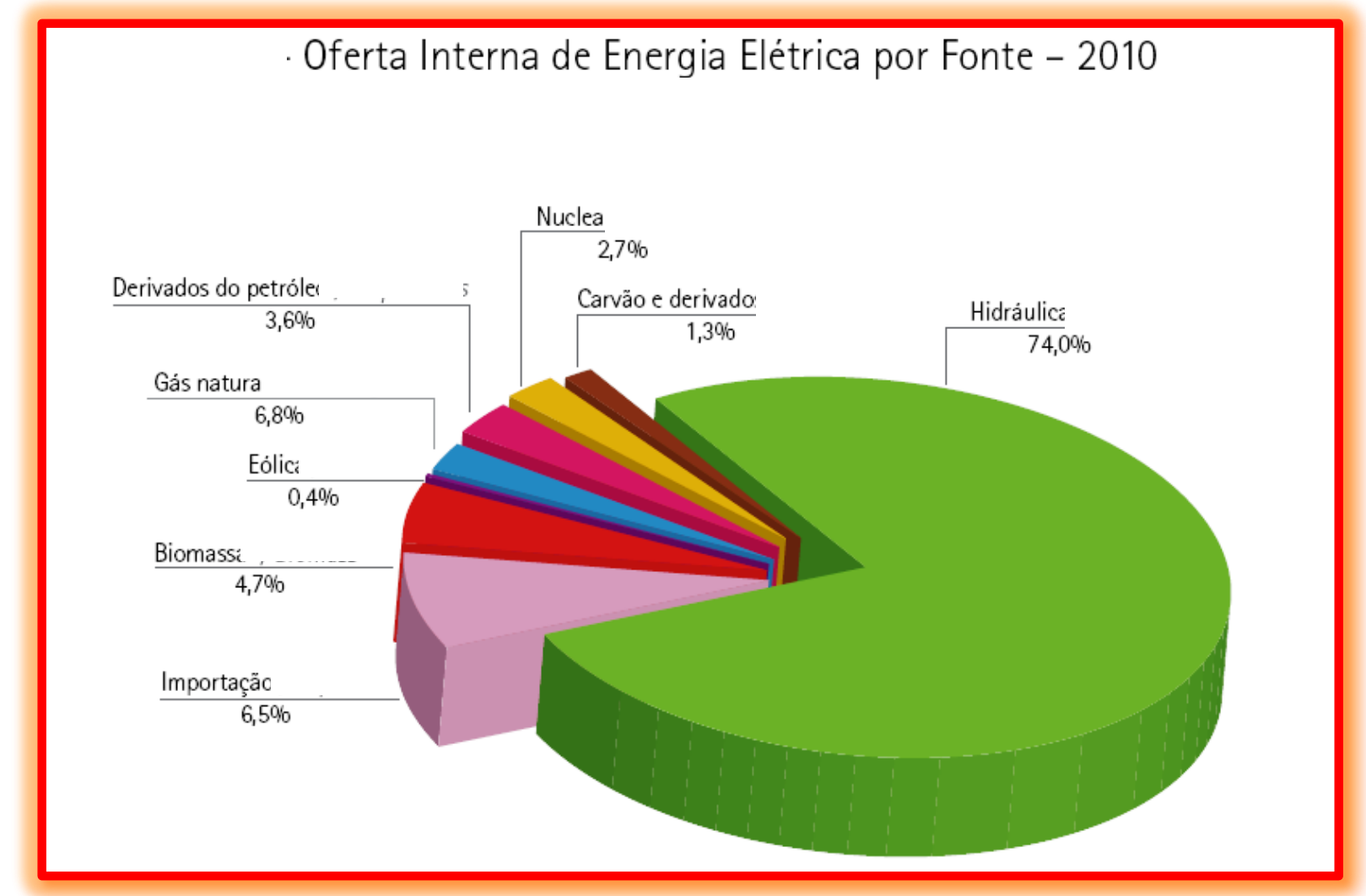

FIGURA 11 - Oferta interna de energia elétrica por fonte no Brasil em 2010. Fonte: MME - EPE (Empresa de Pesquisa Energética) 2011

Podemos observar que a matriz energética brasileira teve como fonte na biomassa, uma contribuição de 4,7\% em 2010, um pequeno aumento comparado à prospecção da FIG.6, podendo avançar mais, à medida que novas tecnologias tenham uma maior injeção de recursos para tornar essa realidade ainda melhor com relação a aplicabilidade desse recurso energético renovável.

Biocombustíveis, bioeletricidade e bioprodutos, são alguns dos produtos que pode se obter a partir da conversão da biomassa, como ilustrado na FIG.12. 


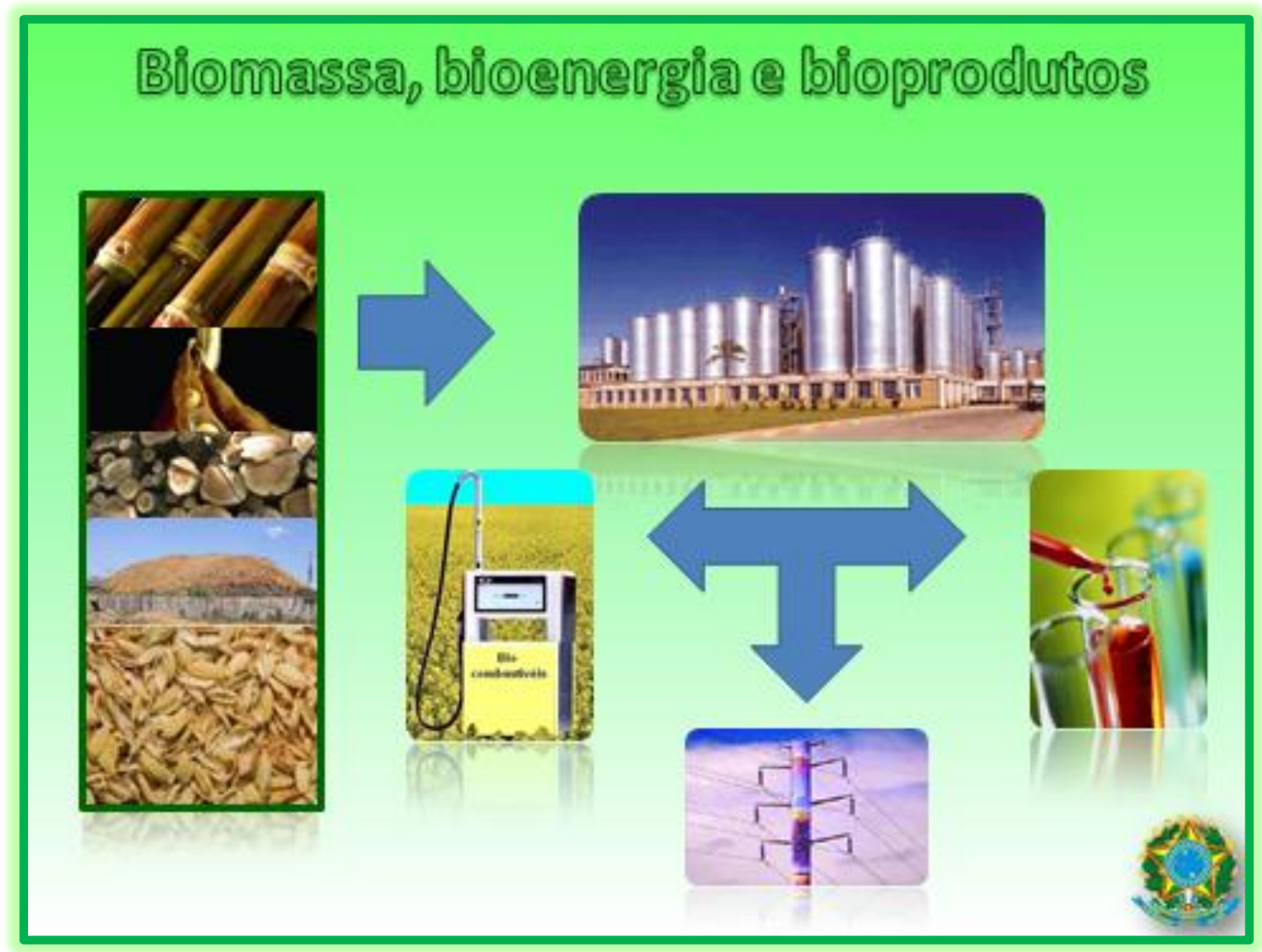

FIGURA 12 - Produtos obtidos a partir das diversas biomassas encontradas no Brasil.

Fonte: $3^{0}$ Congresso Internacional de Inovação,17-18 de novembro 2010 FIERGS Rio Grande do Sul

O aproveitamento da biomassa pode ser feito por meio da combustão direta (com ou sem processos físicos de secagem, classificação, compressão, corte ou quebra, etc.), de processos biológicos (digestão anaeróbica e fermentação), ou de processos termoquímicos (gaseificação, pirólise, liquefação e transesterificação). Na FIG. 13, temos a representação dos principais processos, ou tecnologias, de conversão da biomassa. 


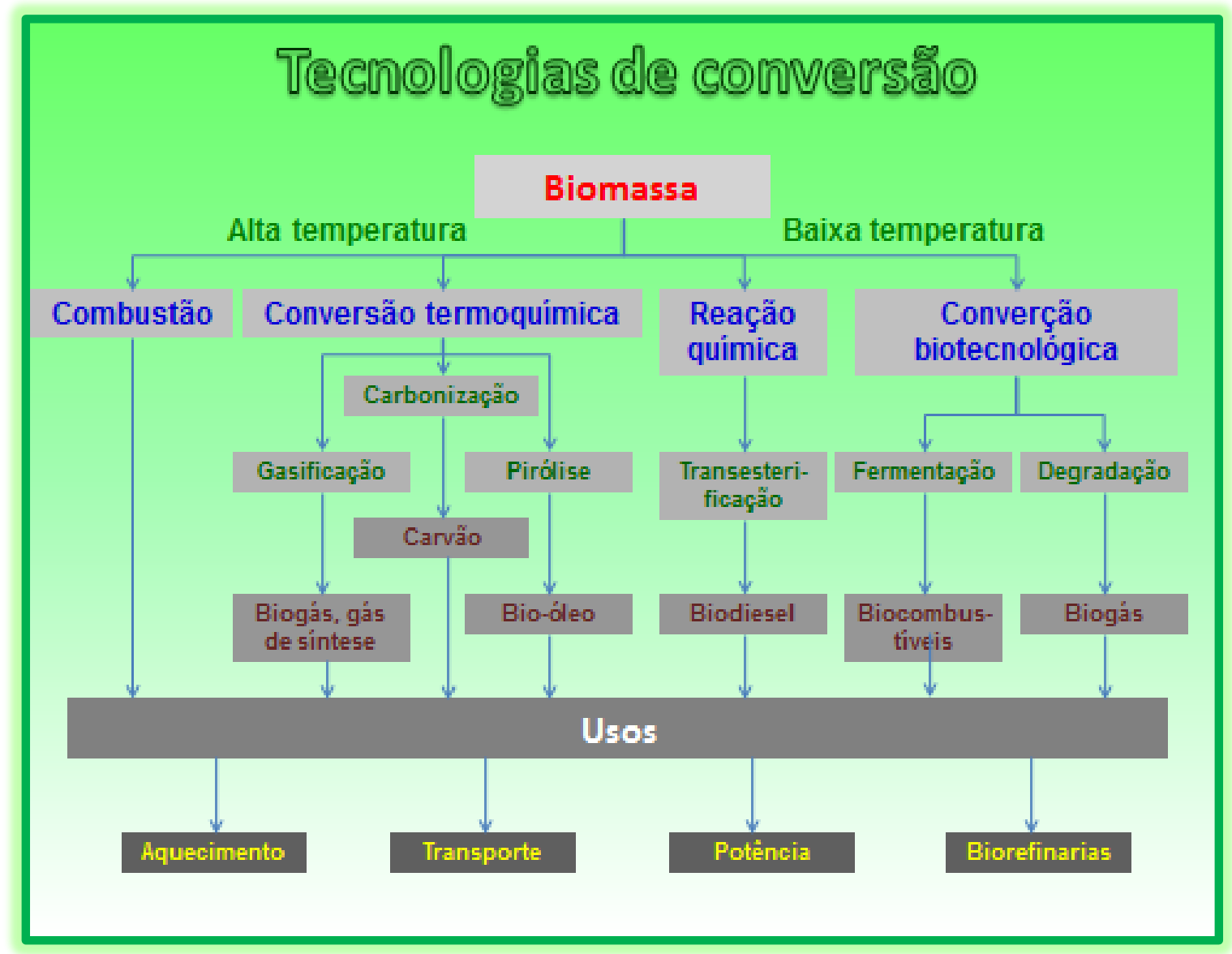

FIGURA 13 - Principais tecnologias de conversão da biomassa.

Fonte: $3^{0}$ Congresso Internacional de Inovação,17-18 de novembro 2010 FIERGS Rio Grande do Sul

Combustão direta é a transformação da energia química dos combustíveis em calor, por meio das reações dos elementos constituintes com o oxigênio fornecido. Para fins energéticos, a combustão direta ocorre essencialmente em fogões (cocção de alimentos), fornos (metalurgia) e caldeiras (geração de vapor); apesar de muito prático, o sistema é deficiente, principalmente no que tange a alta umidade da matéria prima, no caso da lenha, por exemplo, aliado a baixa densidade energética do combustível (lenha, palha, resíduos, etc.), além da dificuldade no armazenamento e transporte ${ }^{[43]}$.

Fermentação é um processo biológico anaeróbico em que os açúcares de plantas como a batata, o milho, a beterraba e, principalmente a cana de açúcar são convertidos em álcool, por meio da ação de microrganismos, geralmente leveduras. Em termos energéticos, o produto final, o álcool, é composto por etanol 
e, em menor proporção, o metanol, sendo usado como combustível em motores de combustão interna ${ }^{[44]}$.

Digestão anaeróbica é um processo simples, que consiste na decomposição do material pela ação de bactérias, na ausência de ar, que ocorre naturalmente com quase todos os compostos orgânicos. $O$ tratamento e o aproveitamento energético de dejetos orgânicos podem ser feitos pela digestão anaeróbica em biodigestores, onde o processo é favorecido pela umidade e aquecimento. O aquecimento é provocado pela própria ação das bactérias, mas em regiões ou épocas onde as temperaturas sejam mais baixas, pode ser necessário calor adicional, uma vez que a temperatura ideal deve ser de pelo menos $35{ }^{\circ} \mathrm{C}$. Em termos energéticos, o produto final, o biogás, é composto principalmente de metano, numa taxa de $50 \%$ a $75 \%$ e dióxido de carbono; o efluente gerado pode ser usado como fertilizante ${ }^{[45]}$.

Esterificação é um processo químico que consiste na reação de óleos vegetais com um produto intermediário ativo oriundo da reação entre alcoóis, metanol ou etanol, e uma base que pode ser hidróxido de sódio ou de potássio. Os produtos dessa reação química são a glicerina e uma mistura de ésteres etílicos ou metílicos (biodiesel). O biodiesel tem características físico-químicas muito semelhantes às do óleo diesel e, portanto, pode ser utilizado em motores de combustão interna, de uso veicular ou estacionário (geração de energia) ${ }^{[46]}$.

Gaseificação é um processo de conversão de combustíveis sólidos em gasosos, por meio de reações termoquímicas, envolvendo vapor quente e ar, ou oxigênio. Há vários tipos de gaseificadores, com diferenças de temperaturas e/ou pressão. Os mais comuns são os reatores de leito fixo e de leito fluidizado. O gás resultante é uma mistura de monóxido de carbono $(\mathrm{CO})$, hidrogênio $\left(\mathrm{H}_{2}\right)$, metano $\left(\mathrm{CH}_{4}\right)$, dióxido de carbono $\left(\mathrm{CO}_{2}\right)$ e nitrogênio, cujas proporções variam de acordo com as condições do processo ${ }^{[47-49]}$.

Pirólise é um processo de conversão de um combustível em outro de melhor qualidade e conteúdo energético. O processo consiste em aquecer o material original, na ausência total ou parcial de ar, até que o material volátil seja retirado. O produto sólido, no caso o carvão, tem uma densidade energética duas vezes maior do que a do material de origem e queima em temperaturas muito mais elevadas. Além de gás combustível, a pirólise produz alcatrão e ácido pirolenhoso, mais conhecidos como bio-óleo. Nos processos em temperaturas 
entre $700{ }^{\circ} \mathrm{C}$ e $900{ }^{\circ} \mathrm{C}$ cerca de $60 \%$ do material se transforma num gás rico em hidrogênio, monóxido de carbono e metano ${ }^{[50]}$.

Como alternativa limpa e renovável na obtenção de hidrogênio, a biomassa tem enorme potencial energético, tanto em escala mundial como no Brasil.

\subsection{Palha do café}

A palha do café ilustrada na FIG.14, foi escolhida como biomassa para o processo de pirólise neste trabalho, porque o Brasil é o maior produtor mundial de café, com uma média de $25 \%$ dessa produção, com uma safra estimada para 2012 de 52,27 milhões de sacas colhidas, em uma área de 2,4 milhões de hectares, com aproximadamente 4 bilhões de pés explorados em 218 mil propriedades em 1572 municípios ${ }^{\text {[51] }}$, gerando toneladas por ano de resíduos que são desperdiçados e queimados na lavoura, contribuindo nas emissões de gases do efeito estufa.

Ainda que grande parte da palha de café seja usada como adubo, ou como fonte de energia para aquecer as fornalhas dos secadores de café, pelos agricultores, ainda restam 2 milhões de toneladas por ano de palha de café que são descartadas, e que poderiam ser aproveitados, segundo o professor Luiz Vicente Gentil, da Universidade de Brasília ${ }^{[52]}$.

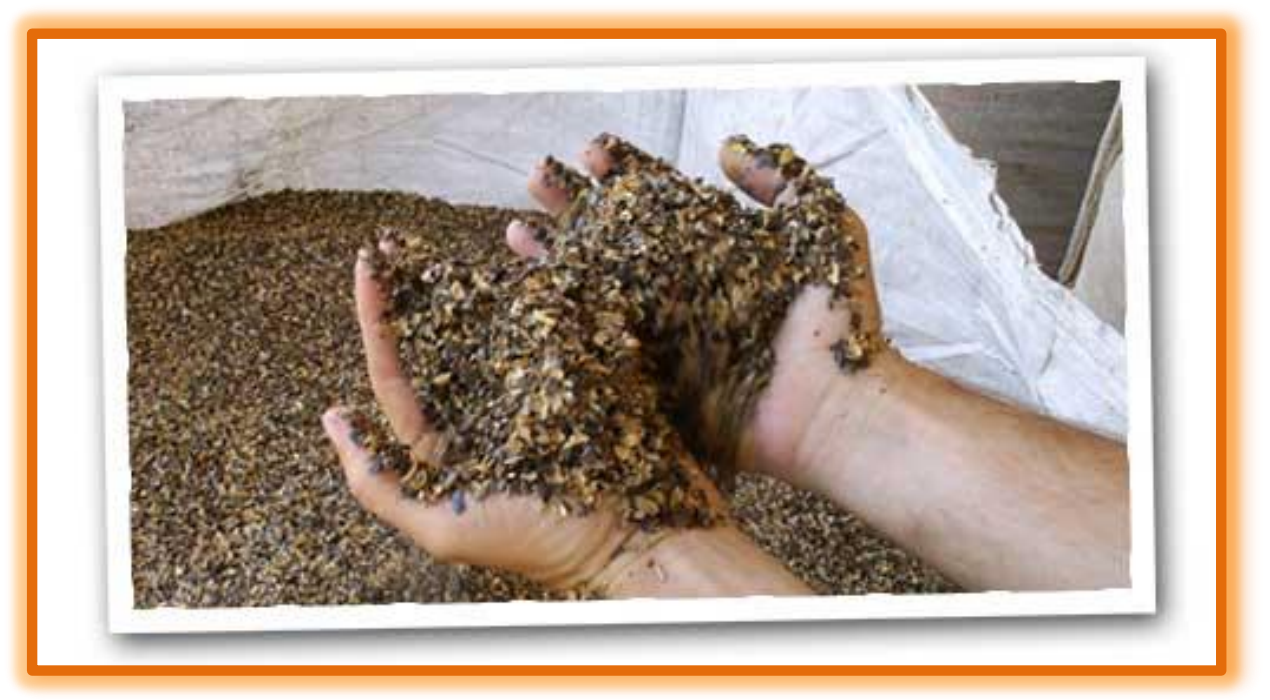

FIGURA 14 - Palha do café. 
O café chegou à Arábia nos séculos XIII e XIV, com a invasão etíope, no Yêmen. Anteriormente, já era utilizado na Etiópia, considerada a pátria do café, onde ficaram conhecidas diversas lendas a respeito de seus efeitos estimulantes, estando ainda presente em estado silvestre nas florestas da região.

No século 18, o café foi levado para a Europa, colônias europeias e Brasil, chegando ao Pará e Estados vizinhos a partir da Guiana Francesa. Em 1774, trazido do Maranhão pelo desembargador João Alberto Castelo Branco, chegou ao Rio de janeiro, espalhando-se pelo vale do Paraíba. Em 1825, foi introduzido em São Paulo e, posteriormente, em Minas Gerais. O esgotamento do ouro direcionou a mão de obra escrava para a cultura cafeeira abrindo-se então, no plano externo, perspectivas de mercado desse produto, devido à sua popularização em outros países.

Em 1840 o Brasil atingiu a liderança do mercado cafeeiro mundial, com grande deslocamento de escravos de outras culturas, para as do café. Após a abolição da escravatura, os imigrantes passaram a trabalhar nas lavouras de café. A riqueza gerada pela exploração do café desencadeou no século XIX, o processo de urbanização e industrialização, notadamente da região Sudeste do país.

Das espécies cultivadas, o Coffea arabica (café arábica) e o Coffea canephora ou Coffea conillon (café robusta) são as mais importantes economicamente, sendo o café arábica responsável por $70 \%$ da produção mundial, por 99\% da produção da América Latina e o que contém menor teor de cafeína. Seus frutos possuem uma complexidade de aromas e sabores que a destacam das outras espécies, tornando-a dessa forma a mais importante espécie do gênero Coffea cultivada para o preparo da bebida.

O café possui na sua composição química, alcaloides purínicos ou xantinas, ácidos orgânicos, flavonoides, dirpenos, salicilato de metila, EDTA, ácido benzoico, trigonelina, óleos essências, vitaminas (ácido ascórbico, riboflavina, caroteno) e minerais (cálcio, fósforo e ferro).

A cafeína, componente natural do café, é um composto químico de fórmula $\mathrm{C}_{8} \mathrm{H}_{10} \mathrm{~N}_{4} \mathrm{O}_{2}$ classificado como alcaloide, do grupo das xantinas. É extremamente solúvel em água quente, não tem cheiro e apresenta

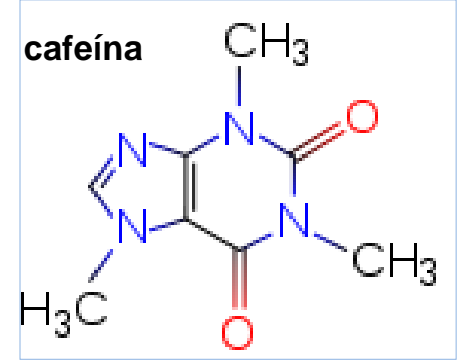


sabor amargo. Entre o grupo das xantinas (que incluem a teofilina e a teobromina) a cafeína é a que mais atua sobre o sistema nervoso central. A presença da cafeína não se atém somente ao grão de café, como também podese verificar sua presença na palha proveniente do beneficiamento da agricultura cafeeira, como citado no capítulo $V$ deste trabalho, resultados e discussões, nos resultados de cromatografia a gás acoplado ao espectrômetro de massa (GC/MS).

Após a colheita do fruto, é feita a limpeza em lavadores/separadores, para retirada de impurezas e sua separação, de acordo com a densidade: os mais secos (ou bóias), cereja (grãos maduros) e verdes (mais densos). O preparo da separação do grão pode ser feito via por seca ou via úmida. No primeiro caso, o fruto do café é colocado em secadores mecânicos ou espalhado em terreiros, onde fica exposto ao Sol. A preparação por via úmida requer o uso de água no processo de despolpamento, onde o grão do café é separado do seu invólucro externo.

Na FIG.15, temos um esquema do sistema convencional de produção do grão de café, torrefação e moagem para a utilização na bebida. 


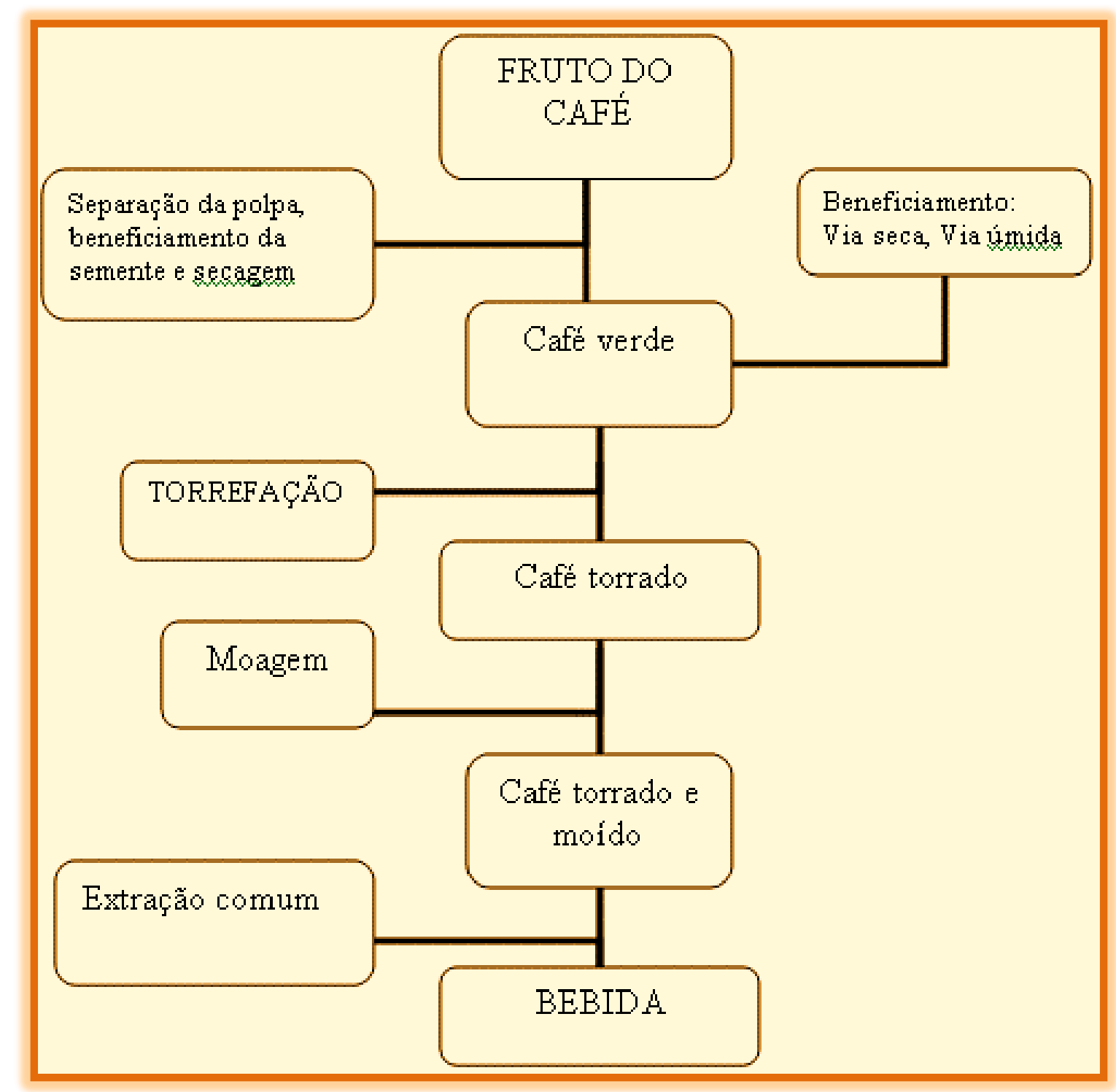

FIGURA 15 - Sistema convencional de produção do grão de café, torrefação e moagem para utilização na bebida.

Fonte: http://br.monografias.com/trabalhos/torrefacao-cafe/torrefacao-cafe2.shtml

O fruto do cafeeiro é formado pelo grão (endosperma + embrião), que é envolvido por uma membrana transparente denominada tegumento, seguido pelo pergaminho (ou endocarpo), por uma camada de pectina (ou mucilagem), pela polpa (ou mesocarpo) e, finalmente, pela casca (ou pericarpo), conforme ilustrado na FIG.16. 


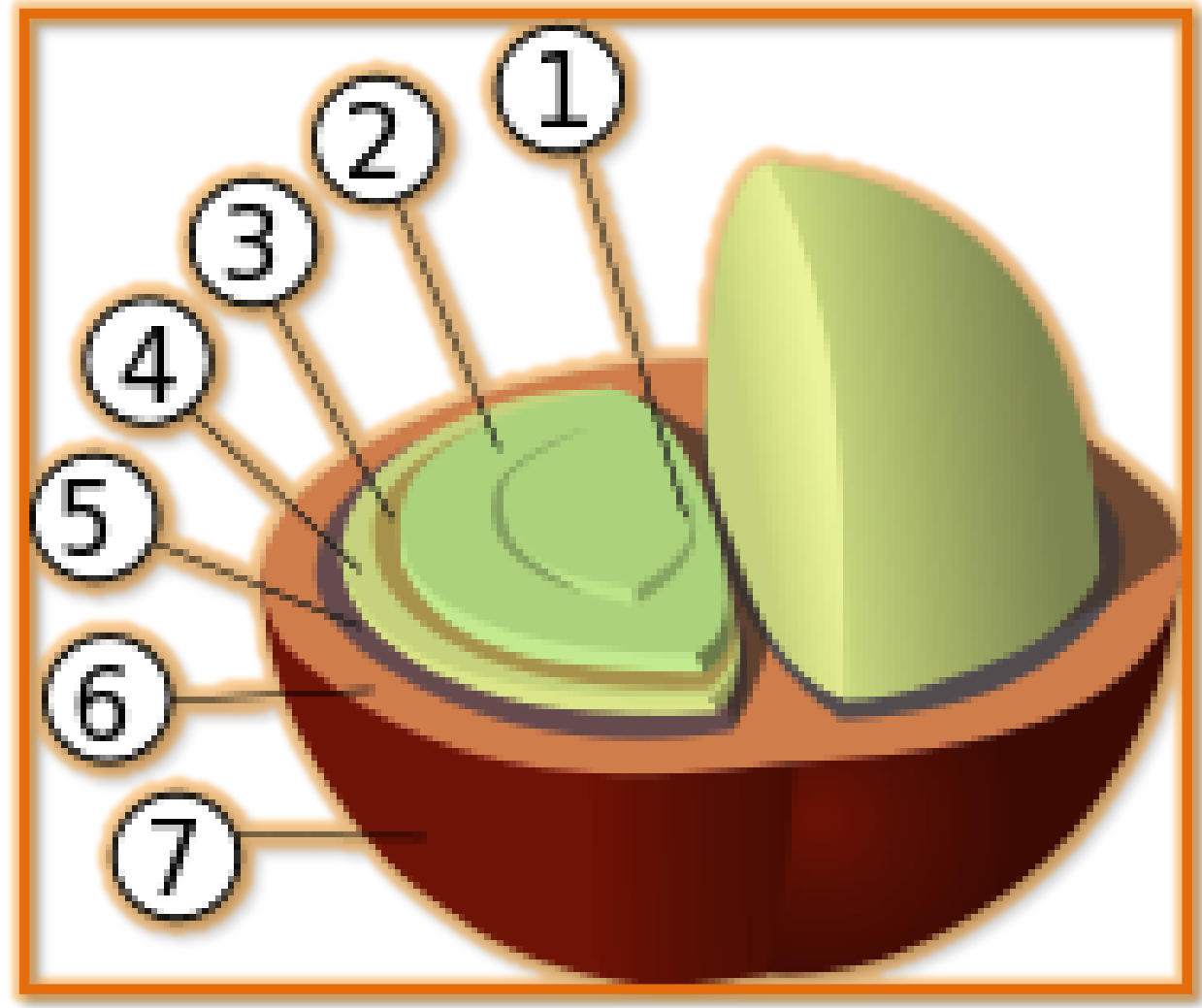

1- Corte central

2- Grão do café (endosperma)

3- Membrana transparente (tegumento)

4- Pergaminho (endocarpo)

5- Camada de pectina (mucilagem)

6- Polpa (mesocarpo)

7- Camada exterior (pericarpo)

FIGURA 16 - Estrutura do grão de café. Fonte: http://www.pedecafe.com

O Pergaminho, a estrutura interna do grão, é uma película que fica entre a casca e o fruto. Constituído basicamente por celulose (50\%) e lignina (22\%). 
A película transparente, também denominada de película prateada, é o envoltório mais externo da semente de café, formada por uma camada de células esclerenquimatosas. Sua função ainda não é exatamente conhecida. Ela contém clorofilas a e b, pode atingir coloração parda ou caramelo, dependendo da região produtora.

A mucilagem é a polpa rica em açúcares situada entre a casca e o pergaminho (endocarpo). Esse elevado teor de açúcares aumenta os riscos de fermentações indesejáveis que poderão comprometer a qualidade final do café.

Após o despolpamento do fruto do café, denominado "côco" ou "cereja", que é o grão de café que se encontra em pleno estágio de maturação, é separado o grão de café do endocarpo, mesocarpo, pericarpo e mucilagem; a esse conjunto, dá-se o nome de "palha de café", sendo esse o material objeto deste estudo.

No Brasil, muitos trabalhos têm sido realizados para avaliar o potencial de utilização de subprodutos agrícolas. Mais especificamente, a palha do beneficiamento do café tem sido estudada com o intuito de agregar valor aos resíduos, considerados como lixo, transformando-os em matéria prima, como alternativa para se evitar transtornos ambientais.

A palha do café foi utilizada na produção de carvão ativado, verificando ser essa biomassa uma boa precursora do processo; o carvão ativado a partir dos rejeitos da lavoura cafeeira, também foi estudado utilizando o cloreto de ferro III $\left(\mathrm{FeCl}_{3}\right)$ como alternativa de agente ativante com resultados bastante promissores [53,54].

Como adsorvente, os resíduos do beneficiamento do café mostraram-se viáveis, tanto na remoção do corante têxtil conhecido como vermelho congo com remoções na ordem de 55\% de resíduos industriais ${ }^{[55]}$, como também na adsorção de íons de metais pesados em soluções de baixa concentração, chegando a $80 \%$ a capacidade adsortiva de cobre e de $60 \%$ a de cádmio ${ }^{[56]}$.

Uma vez que os resíduos agroindustriais apresentam características nutricionais favoráveis à alimentação animal, além de um destino socioeconômico e ambiental interessante para as milhares de toneladas geradas, diversos estudos foram feitos quanto à adição da palha de café como alimento alternativo em dieta animal. 
Sendo a ensilagem um processo alternativo que busca eliminar ou reduzir fatores antinutricionais na dieta animal, a possibilidade da inclusão da palha do café nas rações com diferentes níveis percentuais, apresentou bons coeficientes de digestibilidade, tornando os resíduos da lavoura cafeeira economicamente viáveis em substituição ao milho em até $5 \%$ nas rações suínas, além de aumentar a porcentagem de carne e de cortes magros nos animais ${ }^{[57-59]}$.

Em situações em que a disponibilidade natural de forragens nas pastagens é baixa, ou as reservas de forragens conservadas forem insuficientes para atender às necessidades dos rebanhos, torna a adição da palha de café uma alternativa promissora, objetivando minimizar custos de produção e maximizar a produção de carnes. Estudos com silagem de capim elefante na avaliação de desempenho de ovinos, e também a substituição do milho na dieta, tiveram resultados positivos, quando da adição da palha de café na ração concentrada ${ }^{\text {[60- }}$ 62].

O mesmo pode ser verificado nas dietas do gado leiteiro e de corte, onde a inclusão do resíduo gerado no processamento agroindustrial do café foi considerada positiva sem prejuízo para os animais ou para o produtor, uma vez que oferece a melhor relação custo/benefício, quando observadas as percentagens adequadas.

Em se tratando de vacas em lactação, quanto ao consumo, digestibilidade e produção de leite, melhores resultados são obtidos com a adição de aproximadamente $26 \%$ de casca de café em substituição ao milho da ração concentrada ${ }^{[63]}$, inclusive não alterando a produção e eficiência de síntese de proteína microbiana, bem como o balanço de compostos nitrogenados dos animais ${ }^{[64]}$. Já em novilhas leiteiras, estudos sugerem um percentual menor, em torno de $18 \%{ }^{[65]}$, chegando a $14 \%$ o valor ideal quando na substituição da silagem de milho ${ }^{[66]}$. Novilhos Nelore, mestiços de gado Holandês-Zebú e vacas da raça Holandesa com suplementação da dieta acrescida da palha do café, em 20, 30 e 40\% respectivamente em substituição ao milho desintegrado com palha e sabugo (MDPS), foram averiguados e tidos como promissores tanto na cinética da digestão ruminal, quanto no desempenho ${ }^{[67-69]}$.

A silagem conservada por meio de um processo de fermentação anaeróbica, quando bem feita, tem seu valor nutritivo semelhante ao da própria forragem verde. É um alimento volumoso, usado principalmente para bovinos e 
que na época da seca pode substituir o pasto. Entre as forrageiras mais utilizadas, destaca-se o capim elefante, que na época ideal de corte apresenta alto teor de umidade, podendo prejudicar a fermentação, gerando elevadas quantidades de efluentes. Para otimização do processo tanto do ponto de vista da fermentação propriamente dita, como também da qualidade da silagem e valor nutritivo, alguns aditivos têm sido testados, como é o caso da palha do café que se mostrou bastante eficiente, diminuindo o teor de umidade, eliminando totalmente a produção de efluente, além de promover melhor conservação do material ensilado ${ }^{[70-72]}$.

A utilização da palha do café como cobertura de canteiros no cultivo de alface, em Roraima e em Minas Gerais, respectivamente, obteve resultados satisfatórios na manutenção da produtividade, chegando inclusive a proporcionar melhor crescimento e desenvolvimento da alface (MG), bem como se mostrou eficaz como cobertura morta do solo, no controle de plantas daninhas que afetam o cultivar $(\mathrm{RO})^{[73-74]}$.

Como podemos observar nos trabalhos anteriores citados, muito se tem pesquisado e estudado acerca da utilização dos resíduos provenientes da lavoura cafeeira como fonte de biomassa na substituição, agregação de valor a processos, entre outras alternativas, uma vez que segundo estatísticas, são desperdiçados nas lavouras, resíduos da ordem de 2 milhões de toneladas/ano de palha de café ${ }^{[52]}$.

Nesse sentido, o trabalho aqui proposto torna-se bastante atrativo, promissor e inovador, sendo que a implementação do aproveitamento do resíduo da lavoura cafeeira como fonte de biomassa para obtenção de hidrogênio, por meio de um processo de pirólise, contribui para minorar os aspectos negativos no ambiente e cria alternativa energética para o país.

\subsection{Pirólise}

Pirólise, do grego pyr, pyrós = fogo + lýsis = dissolução. É uma reação de ruptura da estrutura molecular original de um determinado composto pela ação do calor ${ }^{[75]}$. 
A pirólise (também conhecida como termólise) é a degradação térmica dos materiais carbonáceos sólidos, a qual pode ser realizada em ausência completa de um agente oxidante (especificamente oxigênio) ou em uma quantidade tal que a gaseificação não ocorra totalmente. Frequentemente são usadas temperaturas que variam na faixa de $400{ }^{\circ} \mathrm{C}$ a $800{ }^{\circ} \mathrm{C}$, denominadas pirólise a baixa e a alta temperatura, respectivamente ${ }^{[76]}$.

Como um processo de conversão térmica, a pirólise implica na ruptura de ligações carbono-carbono e na formação de ligações carbono-hidrogênio, ou seja, mais apropriadamente, a pirólise é um processo de oxidação-redução na qual uma parte da biomassa é reduzida a carbono e outra parte é oxidada e hidrolisada, dando origem a fenóis, carboidratos, alcoóis, aldeídos, cetonas e ácidos carboxílicos ${ }^{[77]}$.

Essa reação, que aparece também como etapa da gaseificação e da combustão, se produz através de uma série de reações químicas e de processos de transferência de massa e de calor.

Alguns autores a consideram como decomposição térmica com deficiência de oxigênio, ou seja, menor quantidade de ar ou oxigênio que a requerida para a combustão completa, gerando principalmente líquidos e sólidos [78-79].

Os produtos da pirólise são: um sólido carbonoso (resíduo não volátil com um elevado teor de carbono), um produto líquido condensável denominado alcatrão ou bio-óleo (mistura de um grande número de compostos de elevada massa molecular, que são voláteis a temperatura de pirólise, porém condensam a temperatura ambiente) e os gases (produtos de baixa massa molecular os quais tem uma pressão de vapor moderada a temperatura ambiente) ${ }^{[80-83]}$.

As propriedades destes produtos variam em função do material de partida e das condições do processo:

O produto gasoso é composto principalmente por gases não condensáveis, como hidrogênio $\left(\mathrm{H}_{2}\right)$, monóxido de carbono $(\mathrm{CO})$, dióxido de carbono $\left(\mathrm{CO}_{2}\right)$, metano $\left(\mathrm{CH}_{4}\right)$, acetileno ou etino $\left(\mathrm{C}_{2} \mathrm{H}_{2}\right)$, etileno ou eteno $\left(\mathrm{C}_{2} \mathrm{H}_{4}\right)$ e etano $\left(\mathrm{C}_{2} \mathrm{H}_{6}\right)$. O hidrogênio $\left(\mathrm{H}_{2}\right)$ pode ser utilizado para alimentação em células a combustível, dispositivo que utiliza a combinação química entre os gases oxigênio e hidrogênio para geração de energia elétrica, energia térmica e água ${ }^{[84-90]}$. 
O produto sólido carbonoso pode ser utilizado para a produção de carvão ativado e também, devido a seu poder calorífico médio, pode ser utilizado como combustível.

O produto líquido é formado por água e compostos orgânicos (mistura de hidrocarbonetos) de diversas naturezas. Este produto pode ser utilizado diretamente como combustível em caldeiras, motores e turbinas. Além disso, pode ser submetido a tratamentos secundários para melhorar suas propriedades e ser utilizado como combustível em aplicações de transporte. Por último, pode ser utilizado como matéria-prima para a obtenção de produtos químicos como fertilizantes e resinas ${ }^{[91-95]}$.

A distribuição dos produtos da reação de pirólise pode ser modificada dependendo dos parâmetros de reação: a temperatura final, a taxa de aquecimento, tempo de residência do sólido, o tempo de residência dos vapores e pressão. Em função das condições de operação existem diferentes tipos de pirólise ${ }^{\text {[96-101]: }}$

Carbonização ou pirólise lenta: ocorre com temperaturas relativamente baixas (em torno de $400{ }^{\circ} \mathrm{C}$ ) e utiliza longos tempos de residência do sólido que pode durar desde horas até dias. Neste processo se maximiza o rendimento do produto sólido.

Pirólise convencional: ocorre com temperaturas moderadas $\left(500{ }^{\circ} \mathrm{C}\right.$ a $\left.600{ }^{\circ} \mathrm{C}\right)$, baixas taxas de aquecimento $\left(<25{ }^{\circ} \mathrm{C} / \mathrm{min}\right)$ e tempo de residência do sólido que varia entre 5 e 30 minutos. Os rendimentos dos três produtos são bastante similares neste tipo de pirólise .

Pirólise rápida para obtenção do produto líquido: ocorre com temperaturas em torno de $500{ }^{\circ} \mathrm{C}$, com altas taxas de aquecimento $\left(100{ }^{\circ} \mathrm{C} / \mathrm{s}\right) \mathrm{e}$ tempos de residência dos vapores no reator entre 0,5 e $2 \mathrm{~s}$.

Pirólise rápida para obtenção de gás: ocorre a temperaturas maiores que $650{ }^{\circ} \mathrm{C}$, altas taxas de aquecimento e curto tempo de residência dos gases, com valores próximos aos da pirólise rápida para obtenção de produto líquido.

$\mathrm{Na}$ TAB.5, temos ilustrados os diferentes grupos orgânicos encontrados como produtos de pirólise da biomassa ${ }^{[98]}$. 
TABELA 5 - Produtos de pirólise da biomassa

\begin{tabular}{|c|c|c|c|c|}
\hline \multicolumn{2}{|c|}{ Classes } & Tipos & Exemplos & Estrutura Principal \\
\hline \multirow{6}{*}{$\begin{array}{c}\text { Hidrocarbonetos } \\
\text { alifáticos }\end{array}$} & & Alcanos & Tridecano & $>10 \mathrm{C}$ \\
\hline & & & Eicpsane & $\mathrm{C}_{\mathrm{n}} \mathrm{H}_{2 \mathrm{n}+2} \quad \mathrm{n}>20$ \\
\hline & & & Docosane & \\
\hline & & & Tricosane & \\
\hline & & Alqueno & Pentadecano & $\mathrm{CH}_{3}\left(\mathrm{CH}_{2}\right)_{111} \mathrm{CH}_{2} \mathrm{CH}=\mathrm{CH}_{2}$ \\
\hline & & Cíclicos & Limoneno & \\
\hline \multirow{4}{*}{$\begin{array}{c}\text { Hidrocarbonetos } \\
\text { aromáticos }\end{array}$} & 1 anel & Benzeno & Benzeno & \\
\hline & & Metil benzeno & & \\
\hline & Policíclicos & Naftaleno & Naftaleno & \\
\hline & (2 anéis) & Metilnaftaleno & & \\
\hline
\end{tabular}

\begin{tabular}{cccc}
\hline $\begin{array}{c}\text { Policíclicos } \\
\text { (3 anéis) }\end{array}$ & Fenantreno & Fenantreno \\
Policíclico & Fluorene & Fluorene \\
(outros anéis $)$ & Indeno & Indeno
\end{tabular}

\begin{tabular}{lcccc}
\hline Oxigenados & $\begin{array}{c}\text { Oxigenados } \\
\text { alifáticos }\end{array}$ & $\begin{array}{c}\text { Ácidos } \\
\text { carboxilicos }\end{array}$ & Ác. hexadecanóico & $\mathrm{CH}_{3}\left(\mathrm{CH}_{2}\right)_{14} \mathrm{COOH}$ \\
& & Ác. octadecanóico & $\mathrm{CH}_{3}\left(\mathrm{CH}_{2}\right)_{16} \mathrm{COOH}$
\end{tabular}

Metil ester 


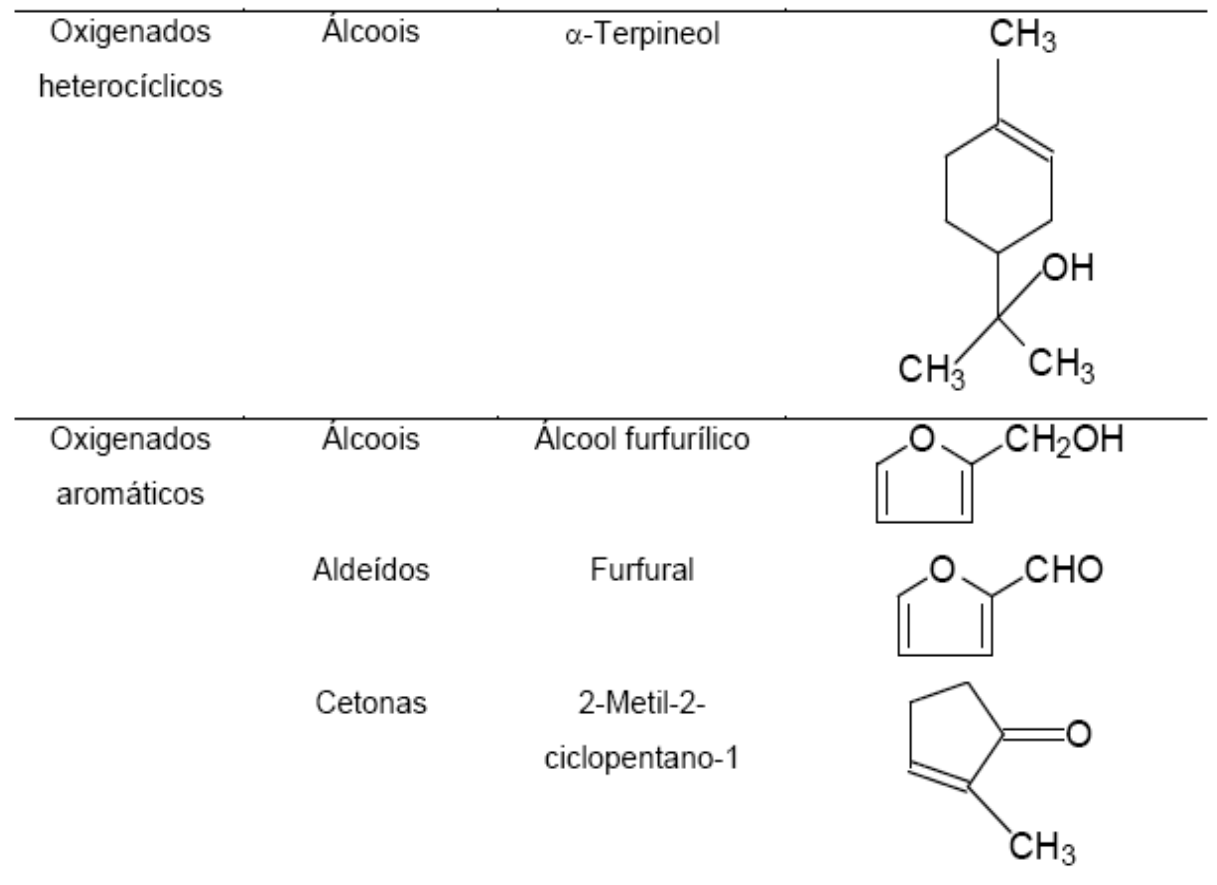

1-Indanone

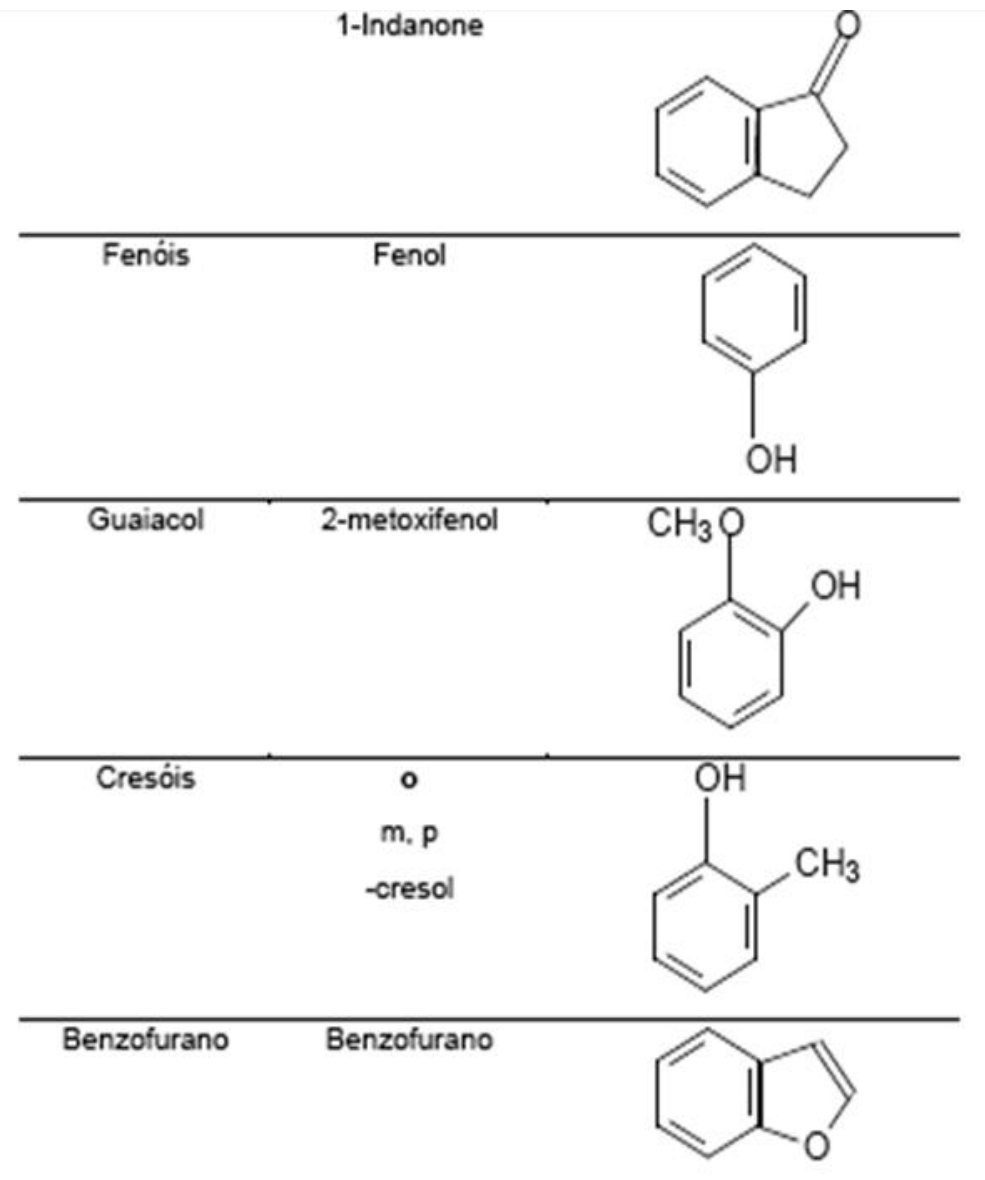




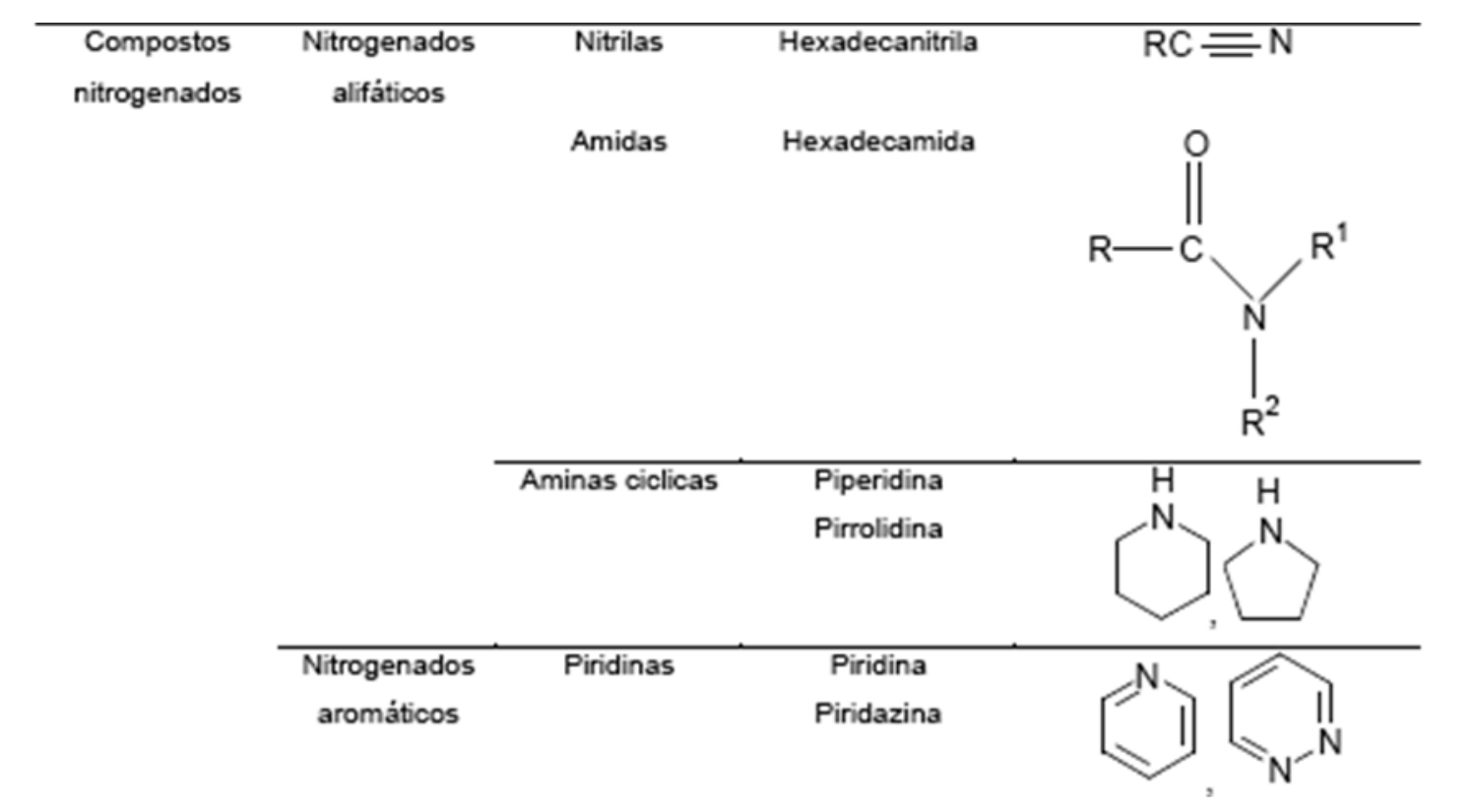

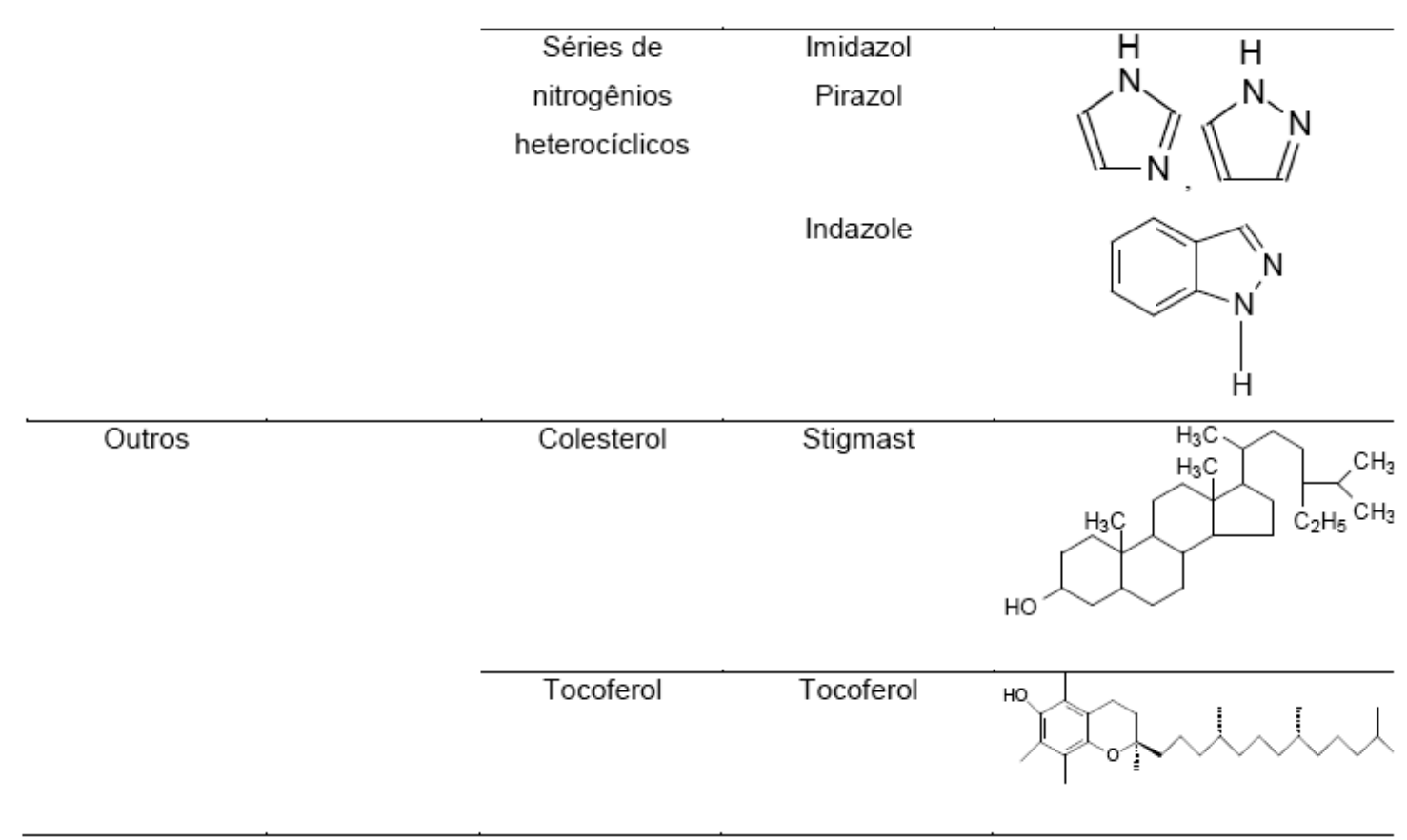

Assim, madeira, resíduos agrícolas, ou qualquer outro tipo de material orgânico pode ser decomposto pelo processo de pirólise ${ }^{[102-104]}$.

A secagem e a pirólise da biomassa, com liberação de água, dos voláteis e do alcatrão (bio-óleo), ocorrem em três fases: primeiro tem-se a evaporação da água, seguida da decomposição dos carboidratos: hemicelulose, celulose, lignina e finalmente a produção de alcatrão (bio-óleo) e ácidos leves. 
Um modelo simplificado de reações para a pirólise de biomassa em atmosfera deficiente de oxigênio $\left(\mathrm{O}_{2}\right)$ pode ser representado pelas seguintes equações ${ }^{\text {[98] }}$ :

Biomassa úmida + calor $\leftrightarrow$ Biomassa seca $+\mathrm{H}_{2} \mathrm{O}(v)$;

Biomassa seca + Calor $\leftrightarrow$ Carvão + gases combustíveis (não condensáveis) + alcatrão (bio-óleo);

$\mathrm{C}(\mathrm{s})+1 / 2 \mathrm{O}_{2}(\mathrm{~g}) \leftrightarrow \mathrm{CO}(\mathrm{g}) \quad \Delta \mathrm{H}=-111 \mathrm{~kJ} / \mathrm{mol}$

$\mathrm{C}(\mathrm{s})+\mathrm{O}_{2}(\mathrm{~g}) \leftrightarrow \mathrm{CO}_{2}(\mathrm{~g}) \quad \Delta \mathrm{H}=-394 \mathrm{~kJ} / \mathrm{mol} ;$

$\mathrm{C}(\mathrm{s})+\mathrm{CO}_{2}(\mathrm{~g}) \leftrightarrow 2 \mathrm{CO}(\mathrm{g})$

$\Delta \mathrm{H}=172 \mathrm{~kJ} / \mathrm{mol}$

$\mathrm{C}(\mathrm{s})+\mathrm{H}_{2} \mathrm{O}(\mathrm{v}) \leftrightarrow \mathrm{CO}(\mathrm{g})+\mathrm{H}_{2}(\mathrm{~g}) \quad \Delta \mathrm{H}=175 \mathrm{~kJ} / \mathrm{mol}$

$\mathrm{C}(\mathrm{s})+2 \mathrm{H}_{2} \mathrm{O}(\mathrm{v}) \leftrightarrow \mathrm{CO}_{2}(\mathrm{~g})+2 \mathrm{H}_{2}(\mathrm{~g}) \quad \Delta \mathrm{H}=178 \mathrm{~kJ} / \mathrm{mol} ;$

$\mathrm{C}(\mathrm{s})+2 \mathrm{H}_{2}(\mathrm{v}) \leftrightarrow \mathrm{CH}_{4}(\mathrm{~g})$

$\Delta \mathrm{H}=-74,8 \mathrm{~kJ} / \mathrm{mol}$

$\mathrm{CO}(\mathrm{g})+1 / 2 \mathrm{O}_{2}(\mathrm{~g}) \leftrightarrow \mathrm{CO}_{2}(\mathrm{~g})$

$\Delta \mathrm{H}=-238,7 \mathrm{~kJ} / \mathrm{mol} ;$

$\mathrm{CO}(\mathrm{g})+\mathrm{H}_{2} \mathrm{O}(\mathrm{v}) \leftrightarrow \mathrm{CO}_{2}(\mathrm{~g})+\mathrm{H}_{2}(\mathrm{~g}) \quad \Delta \mathrm{H}=285 \mathrm{~kJ} / \mathrm{mol}$

$\mathrm{CO}(\mathrm{g})+3 \mathrm{H}_{2}(\mathrm{~g}) \leftrightarrow \mathrm{CH}_{4}(\mathrm{~g})+\mathrm{H}_{2} \mathrm{O}(\mathrm{v}) \quad \Delta \mathrm{H}=-250 \mathrm{~kJ} / \mathrm{mol}$

Podem ser basicamente quatro os fenômenos observados quando a temperatura da biomassa aumenta. O primeiro aparece à temperatura de até aproximadamente $200{ }^{0} \mathrm{C}$ quando ocorre a secagem do material, sendo envolvidos neste processo além da água, traços de $\mathrm{CO}_{2}$, ácido fórmico, ácido acético, etc.

$\mathrm{O}$ segundo fenômeno aparece à temperatura na faixa de $200{ }^{0} \mathrm{C} \quad \mathrm{a}$ $300{ }^{\circ} \mathrm{C}$, onde os produtos anteriores se envolvem em quantidades maiores e a biomassa é convertida em carvão vegetal (fenômeno de torrefação decomposição térmica da hemicelulose e parcialmente da celulose). 
O terceiro fenômeno identificado na faixa de temperatura $300{ }^{0} \mathrm{C} \quad \mathrm{a}$ $500{ }^{0} \mathrm{C}$ corresponde com a degradação térmica da celulose, produzindo quantidades de monóxido de carbono, hidrogênio, metano, etanol, formaldeídos e alcatrão (bio-óleo).

O quarto fenômeno ocorre a temperaturas acima de $500{ }^{0} \mathrm{C}$ onde ocorrem reações dos produtos gasosos já formados com o resíduo sólido, produzindo-se produtos combustíveis, sendo que a água e o $\mathrm{CO}_{2}$ podem reagir com o carvão residual para produzir $\mathrm{CO}$ e $\mathrm{H}_{2}$.

Como mostram os dados de entalpia, as reações 7,8,12,13 e 15 são termodinamicamente exotérmicas, e as reações $9,10,11$ e 14 são termodinamicamente endotérmicas. A temperaturas elevadas entre $800{ }^{0} \mathrm{C}$ e $1000{ }^{0} \mathrm{C}$, os valores de entalpia podem variar em relação aos valores listados. As reações mostram ser reversíveis sob as condições de pirólise e o ponto de equilíbrio varia com a temperatura e a pressão do processo.

A baixas temperaturas $\left(\sim 400{ }^{\circ} \mathrm{C}\right)$ as reações químicas de termoconversão durante o processo de pirólise rápida, constituem a etapa controladora do processo, devido às baixas taxas de reação (cinética do processo). A elevadas temperaturas o processo de difusão dos gases na mistura heterogênea (transferência de massa) se converte no fator controlador do processo.

Observou-se que na literatura há diferentes terminologias com relação à nomenclatura do produto líquido da pirólise.

Foram encontrados termos tais como: alcatrão, ácido pirolenhoso, licor pirolenhoso, bio-óleo, etc., de acordo com os diferentes autores pesquisados.

Neste trabalho, definiu-se como "bio-óleo" o termo a ser utilizado para o produto líquido do processo de pirólise, líquido este que convenientemente conservado, pode ser usado como insumo químico para outros processos, tais como: imitar o sabor dos defumados na indústria alimentícia, substituir o fenol em resinas, servir de aditivo para argamassa na construção civil, substituir os pesticidas químicos, servir de aditivo de colas para madeiras compensadas, etc.

Dentre esses gases produzidos pelo processo de pirólise encontra-se 0 hidrogênio, vetor energético para a produção de energia limpa. 


\subsection{Hidrogênio}

"A utilização do hidrogênio puro é o desígnio final e aquele que nos pode trazer uma solução duradoura para a economia mundial" [105]

A ideia de utilização do hidrogênio como combustível é bastante antiga e iniciou-se em 1776 com o cientista britânico Henry Cavendish que o isolou e em 1839 quando William Robert Grove começou a desenvolver as células a combustível.

Num estudo apresentado à Real Sociedade de Londres, Cavendish descreveu uma experiência em que produzira água combinando oxigênio e hidrogênio com o auxílio de uma centelha elétrica. Como os elementos ainda não haviam recebido seus respectivos nomes, ele chamou a um de "ar sustentador da vida" e a outro "ar inflamável" ${ }^{[14]}$.

O químico francês Antoine Laurent Lavoisier repetiu com êxito a experiência de Cavendish em 1785 e chamou o "ar sustentador da vida" de oxigênio, e o "ar inflamável" de hidrogênio ${ }^{[15]}$.

Nos anos 20, o hidrogênio foi comercialmente produzido pelas primeiras células eletrolíticas, pela hoje conhecida Electrolyser Corporation do Canadá, uma das maiores montadoras de fábricas de hidrogênio eletrolítico do mundo.

O hidrogênio foi explorado como combustível na aviação nos anos 20 e 30. Os alemães usaram-no como combustível auxiliar nos dirigíveis conhecidos como Zepelins.

Nos anos 30 e 40, o hidrogênio foi utilizado na Alemanha e na Inglaterra como experiência em automóveis, caminhões, locomotivas e mesmo submarinos e torpedos sem rastro.

Embora o hidrogênio tenha sido largamente empregado no processo de refinamento como recurso abastecedor, como matéria prima para a produção de fertilizantes derivados de amônia, na hidrogenação de óleos orgânicos comestíveis, fabricação de polipropileno, refrigerante para geradores e motores, seu valor como combustível foi em grande parte ignorado na época posterior à segunda guerra mundial.

Com a crise do petróleo em 1973, o hidrogênio começou a ser reconsiderado como forma de energia por engenheiros, cientistas e políticos, 
donde surgiu a International Association for Hydrogen Energy, quando da primeira conferência ocorrida em Miami Beach, naquele ano.

O hidrogênio é o mais simples e o mais abundante elemento, compondo $75 \%$ da massa e $90 \%$ das moléculas do universo ${ }^{[14]}$. Possui a maior quantidade de energia por unidade de massa que qualquer outro combustível conhecido: 52000 BTU/lb $(120,7 \mathrm{~kJ} / \mathrm{g})$, cerca de três vezes mais calor por $\mathrm{kg}$ se comparado ao petróleo ${ }^{[12]}$. É por esse motivo que sua utilização como fonte renovável de energia elétrica e também térmica, vem sendo amplamente pesquisada.

Esse composto primordial, constituído quimicamente por um único elétron em torno do núcleo possui, por esse motivo, forças de ionização baixas, o que permite a fácil extração do elétron que o orbita, ionizando o hidrogênio e produzindo assim uma corrente elétrica.

O hidrogênio para fins energéticos pode vir de diversas fontes tais como: hidrelétrica, PCHs (pequenas centrais hidrelétricas), fotovoltaica, nuclear, solar, biomassa, etanol, e de origem fósseis, como ilustrado na FIG.17.

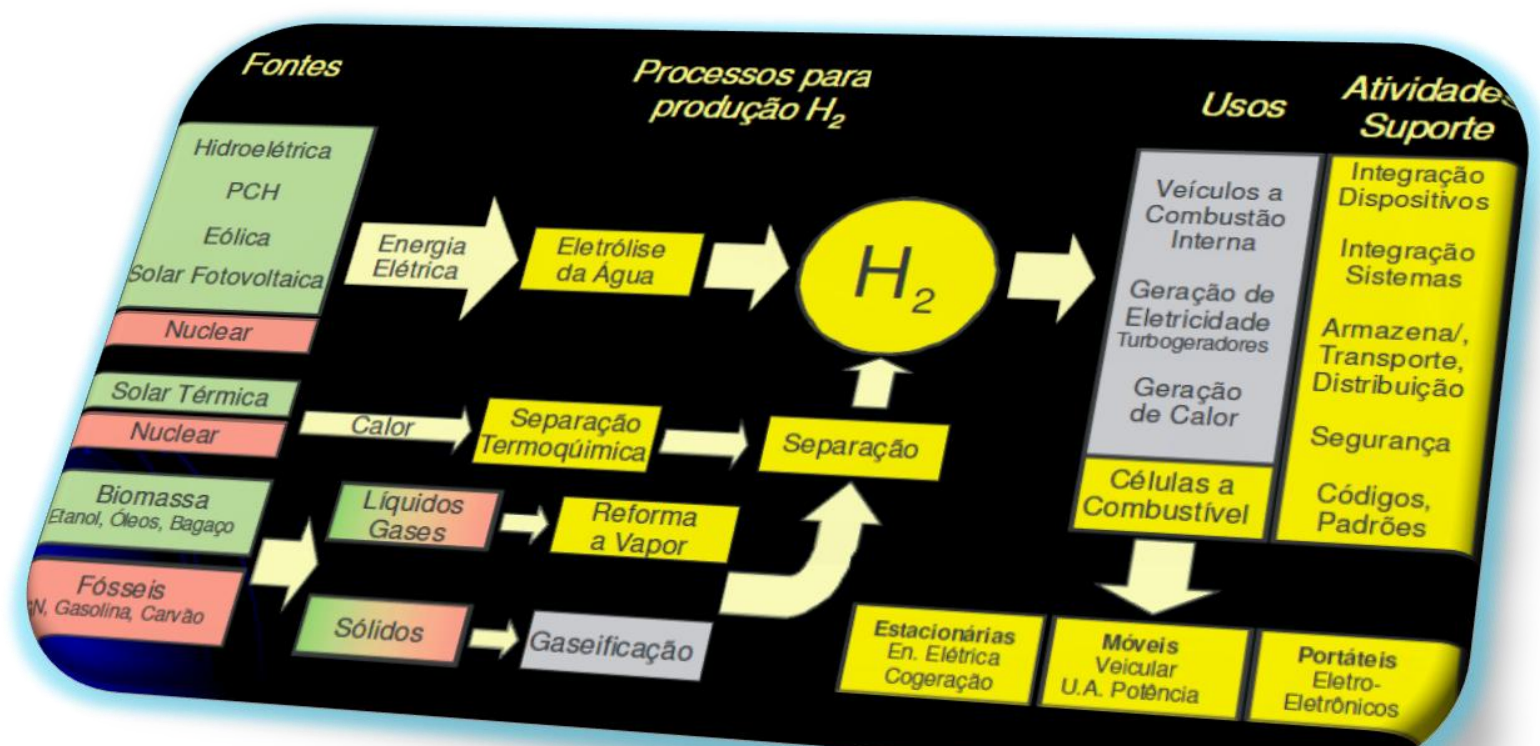

FIGURA 17 - Hidrogênio para fins energéticos.

Fonte: Pimenta, N. - Painel setorial Inmetro - 2010

O hidrogênio quando da sua utilização deve estar na forma pura, ou seja: líquida ou gasosa, para que produza energia eficientemente. Apresenta uma 
inflamabilidade elevada, mas não é maior do que a do gás natural, também fonte de obtenção do hidrogênio.

Quando queimado com oxigênio puro, os únicos produtos são calor e água. Quando queimado com ar, constituído por cerca de 68\% de nitrogênio, alguns óxidos de nitrogênio $\left(\mathrm{NO}_{\mathrm{X}}\right)$ são formados. Ainda assim, a queima de hidrogênio produz menos poluentes atmosféricos que os combustíveis fósseis.

Porém, apesar de ser abundante, não se encontra à disposição na natureza como elemento puro, mas associado ao oxigênio na água, ou ao carbono em compostos orgânicos ${ }^{[106]}$.

No seu estado natural, e sob condições ambientes de temperatura e pressão, o hidrogênio é um gás incolor, inodoro, insípido e muito mais leve do que o ar. Ele também pode estar no estado líquido, ocupando um espaço 700 vezes menor do que se estivesse em forma de gás. Entretanto, tem que estar armazenado a uma temperatura de $-253^{\circ} \mathrm{C}$, em sistemas de armazenamento conhecidos como "sistemas criogênicos". Acima dessa temperatura, o hidrogênio não pode ser liquefeito, mas pode ser armazenado em forma de gás comprimido em cilindros de alta pressão.

Um exemplo do potencial energético do hidrogênio está na fonte de energia do Sol, pois compõe $30 \%$ da massa solar. É com a energia do hidrogênio que o Sol aquece a terra, favorecendo a vida em nosso planeta ${ }^{[107]}$.

A maior parte do hidrogênio obtido atualmente em escala industrial baseia-se no processo de reforma de vapor que utiliza energia térmica para dissociar o hidrogênio. Esta energia, cuja origem é predominantemente a queima de combustíveis fósseis, é responsável pela emissão de grande quantidade de gases de efeito estufa e, portanto, ambientalmente inaceitável em longo prazo.

Outro modo usual de produzir hidrogênio é a eletrólise, pela qual o hidrogênio e o oxigênio que constituem as moléculas da água, são dissociados pela passagem de uma corrente elétrica, método este que igualmente utiliza energia, mas não necessariamente de origem térmica, podendo ser hidráulica ou nuclear ou de outra fonte não poluente da atmosfera, como ilustrado na FIG.18. 


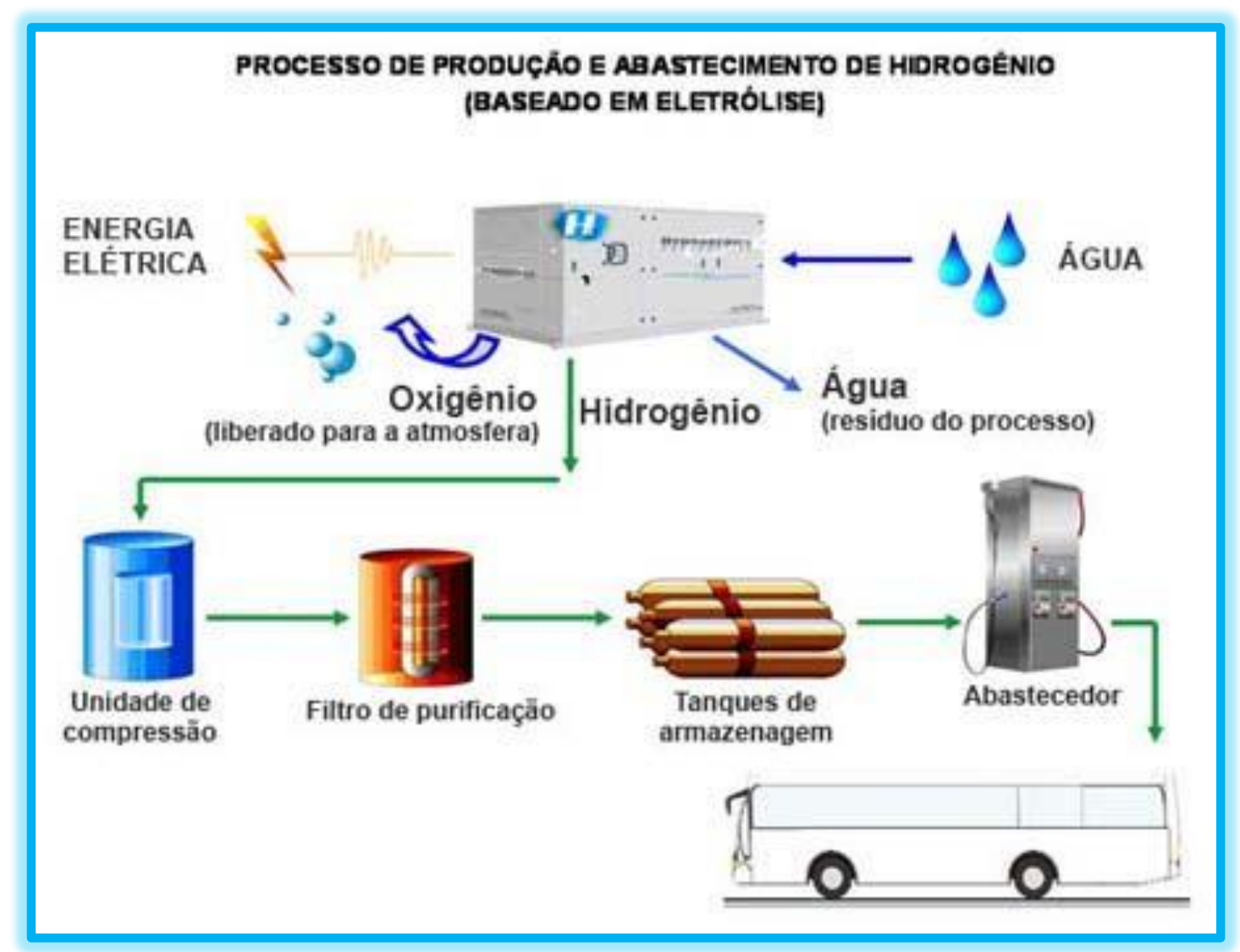

FIGURA 18 - Processo de produção e abastecimento de hidrogênio por eletrólise. Fonte: http://www.profpc.com.br

A "economia de hidrogênio" [14] poderia ser definida como sendo um sistema em que o hidrogênio seria usado, inicialmente, para o emprego mais eficiente dos atuais recursos de hidrocarbonetos e, posteriormente, com o objetivo final de substituir a gasolina e o diesel, derivados do petróleo por um combustível menos poluente ${ }^{[108-112]}$. Por outro lado, o uso do hidrogênio como vetor de energia reduziria a dependência do petróleo, simultaneamente reduzindo a poluição e as emissões de gases de efeito estufa, desde que a fonte primária de energia para sua produção não seja um combustível fóssil. Uma conquista recente e fundamental neste sentido foi o desenvolvimento do conversor de energia baseado na célula a combustível ${ }^{[113,114]}$.

Apesar da associação das células a combustível às tecnologias modernas, o princípio de funcionamento delas foi descoberto há mais de 150 anos. A tecnologia das células a combustível é anterior à do motor de combustão interna, inventado por Nikolaus Otto em 1876, e à do motor de 
compressão/ignição, inventado por Rudolf Diesel em 1892. Na realidade, a história das células a combustível iniciou-se em 1839 por intermédio de um jurista britânico, tornado cientista, de nome William Robert Grove.

A partir de experimentações de caráter simples, Grove descobriu que a eletrólise da água em ácido sulfúrico diluído era reversível, ou seja, utilizando dois elétrodos de platina parcialmente mergulhados numa solução aquosa ácida e com a parte restante isolada separadamente por dois reservatórios contendo oxigênio e hidrogênio, conseguiu verificar que o sistema produzia trabalho elétrico. Além disso, este pesquisador verificou que ao combinar em série diversas células deste tipo, podia produzir corrente elétrica suficiente para fazer a eletrólise da água, como mostra a FIG.19. Como conclusão de seu experimento, Grove designou o aparelho descoberto como sendo uma bateria gasosa: a primeira célula a combustível.

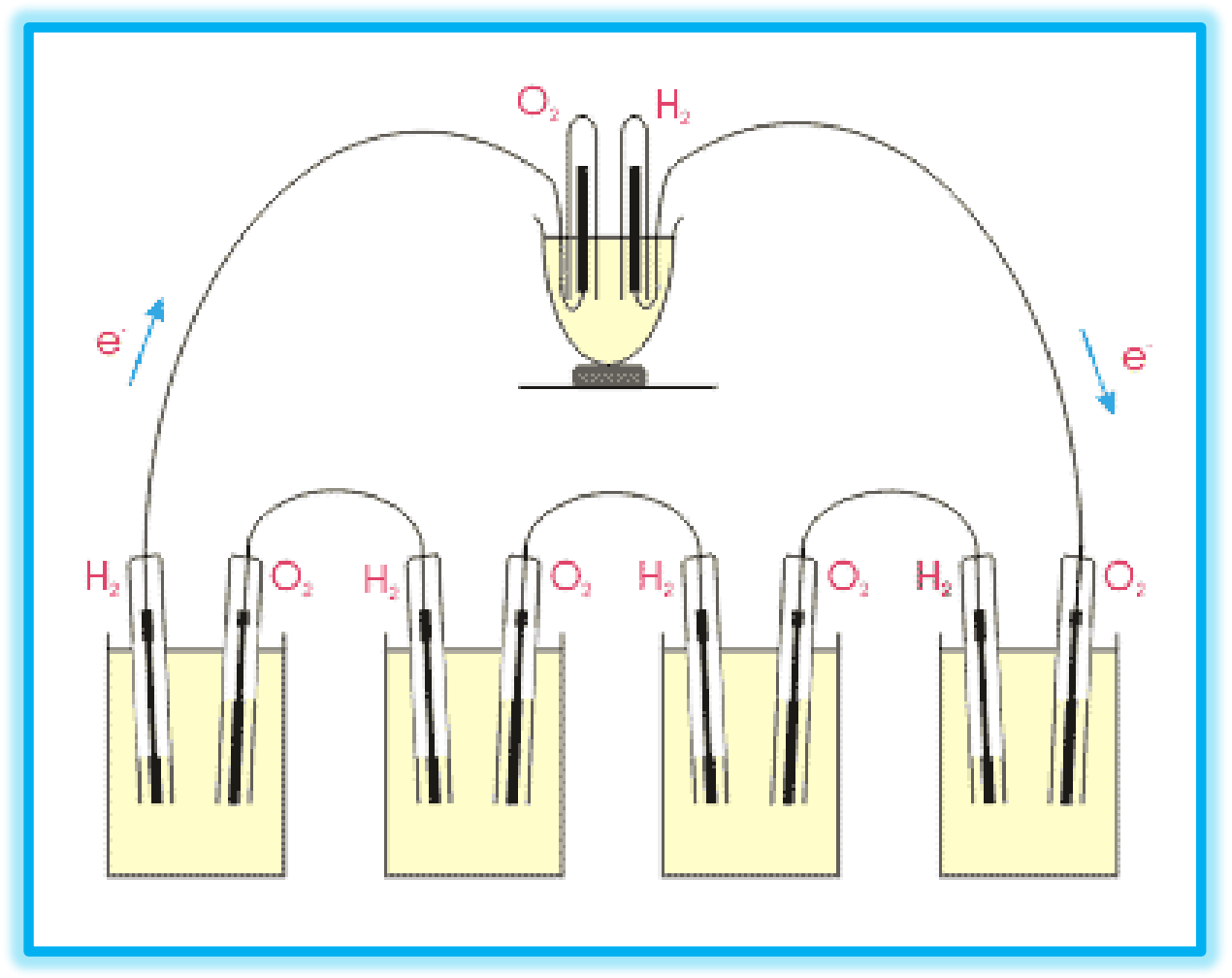

FIGURA 19 - Esquema do primeiro experimento de uma célula a combustível realizado por Grove em 1839. 
A célula a combustível como dispositivo capaz de gerar energia, vem sendo desenvolvido em função da busca por alternativas energéticas que satisfaçam a necessidade de redução dos impactos ambientais. Entre suas aplicações estão a produção de energia elétrica estacionária e a utilização em transporte, equipamentos portáteis e satélites ${ }^{[115]}$.

Um sistema simplificado do funcionamento de uma célula a combustível pode ser visualizado na FIG.20.

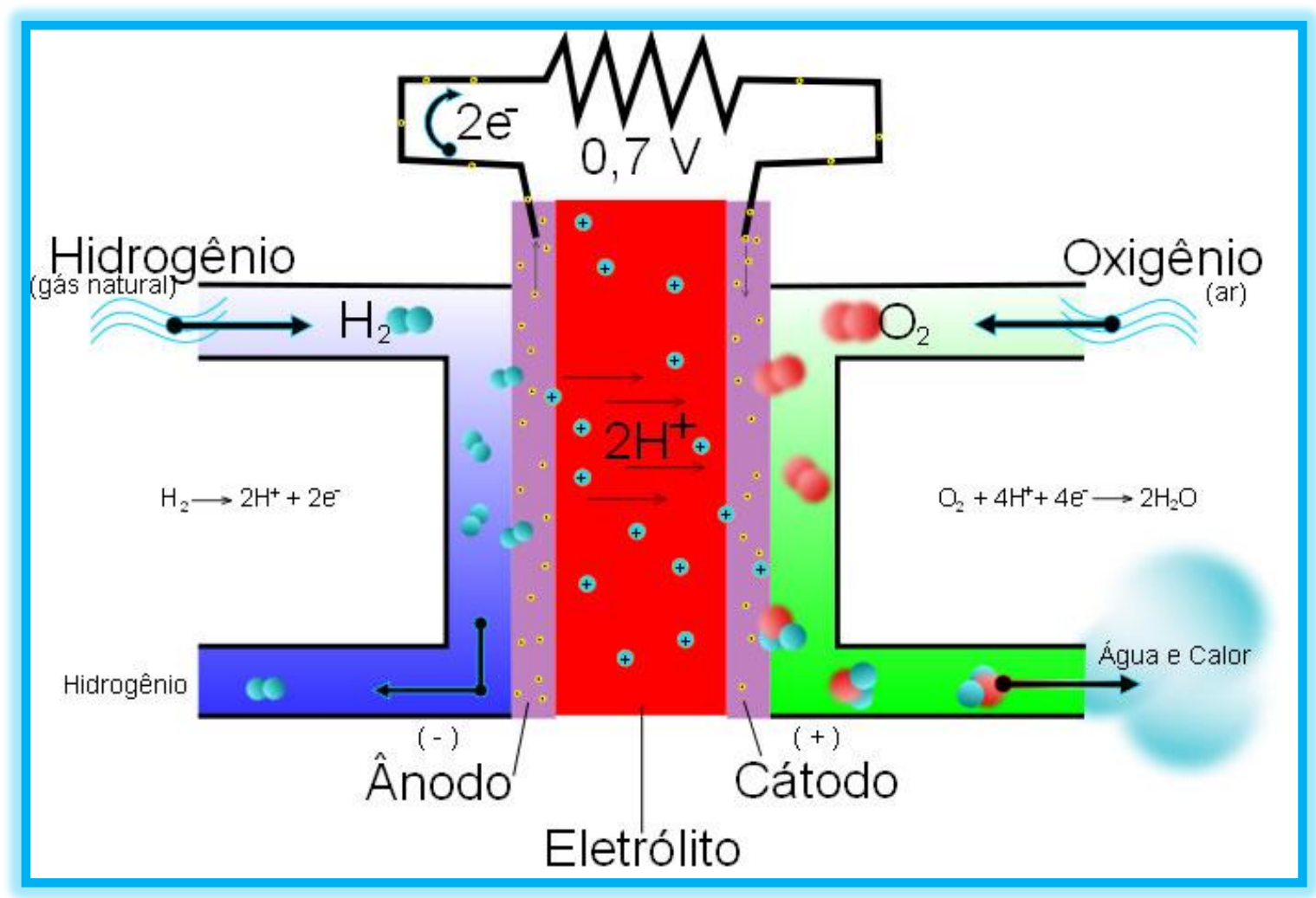

FIGURA 20 - Esquema simplificado de uma célula a combustível.

Fonte: http://www.raiadiplomatica.com/196

A conversão eletroquímica de uma célula a combustível ocorre por meio de duas semi-reações em dois eletrodos, separados por um eletrólito apropriado, ou seja, a oxidação de um combustível no ânodo, e a redução de um oxidante no cátodo ${ }^{[116]}$. Na figura acima, o hidrogênio corresponde ao combustível, e o oxigênio ao oxidante; tem-se a formação de água e produção de calor, liberando elétrons livres, que podem gerar trabalho elétrico. 
As principais células a combustível $(\mathrm{CaC})$ podem ser classificadas em: Célula Alcalina (AFC - Alkaline Fuel Cell)), Célula a Membrana Polimérica (PEMFC - Proton Exchange Membrane Fuel Cell), Célula a Ácido Fosfórico (PAFC - Phosphoric Acid Fuel Cell) ), Célula de Carbonato Fundido (MCFC Molten Carbonate Fuel Cell)), Célula a Óxido Sólido (SOFC - Solid Oxide Fuel Cell) e são diferenciadas de acordo com o tipo de eletrólito, temperatura de operação e combustível utilizado, conforme ilustrado na TAB.6.

TABELA 6 - Classificação das principais células a combustível

\begin{tabular}{|cccc|}
\hline CaC & Eletrólito & Temperatura $\left({ }^{\circ} \mathrm{C}\right)$ & Combustível \\
\hline AFC & Solução alcalina & $<120$ ou $\sim 250$ & $\mathrm{H}_{2}$ \\
\hline PEMFC & $\begin{array}{c}\text { Membrana trocadora } \\
\text { de íons }\end{array}$ & $\mathrm{H}_{2}$ \\
\hline & $60-120$ & $\mathrm{H}_{2}, \mathrm{GN}$ e afins \\
\hline PAFC & $\begin{array}{c}\text { Solução de ácido } \\
\text { fosfórico }\end{array}$ & $160-220$ & $\mathrm{H}_{2}, \mathrm{GN}$ e afins \\
\hline MCFC & Carbonato alcalino & $600-800$ \\
\hline SOFC & Material cerâmico & $800-1000$ & GN e afins \\
\hline & & & \\
\hline
\end{tabular}

A célula a combustível do tipo alcalina (AFC) foi desenvolvida pela NASA para aplicação espacial, baseada nas pesquisas e experimentos de Bacon, em 1930. As características dessa célula eram a operação numa faixa de temperatura de 200 a $240{ }^{\circ} \mathrm{C}$, hidróxido de potássio $(\mathrm{KOH})$ concentrado em $45 \%$, pressão entre 40 e 55 atm, para evitar que o eletrólito entrasse em ebulição. 0 anodo consistia de um eletrodo de níquel (Ni) poroso e o catodo, de óxido de níquel (NiO) poroso.

A célula AFC é considerada como a mais eficiente devido à cinética da reação de redução do oxigênio favorecida em meio alcalino. Sua eficiência termodinâmica chega próximo dos $80 \%$. Atualmente utiliza-se $\mathrm{KOH}$ concentrado 
quando a célula opera a altas temperaturas (em torno de $250{ }^{\circ} \mathrm{C}$ ), ou $\mathrm{KOH}$ menos concentrado para operação a temperaturas mais baixas $\left(\leq 120^{\circ} \mathrm{C}\right)$.

Uma desvantagem a ser considerada nesse tipo de célula, é o "envenenamento" do catalisador pelo monóxido de carbono (CO) e o dióxido de carbono que reage com $0 \mathrm{KOH}$ formando $\mathrm{K}_{2} \mathrm{CO}_{3}$ alterando a composição do eletrólito.

No Programa Espacial Apollo, as células a combustível do tipo AFC tinham formato cilíndrico de $57 \mathrm{~cm}$ de diâmetro, $112 \mathrm{~cm}$ de comprimento e pesavam $110 \mathrm{~kg}$, com potência de pico de 1,42 kW entre 27 e $31 \mathrm{~V}$ e potência média de 0,6 kW. A alimentação era feita com $\mathrm{H}_{2}$ puro e $\mathrm{O}_{2}$, o eletrólito concentrado a $85 \%$ em $\mathrm{KOH}$.

Já no Programa Espacial Shuttle, as células eram de formato retangular com $38 \mathrm{~cm}$ de largura, $101 \mathrm{~cm}$ de comprimento e $35 \mathrm{~cm}$ de altura pesando $91 \mathrm{~kg}$. A potência de pico girava em torno de $12 \mathrm{~kW}$ em 27,5 V, a uma potência média de 7 kW ${ }^{[117-119]}$.

As células a combustível com membrana polimérica como eletrólito (PEMFC) são ideais na utilização em automotores onde a partida rápida é necessária, bem como em sistemas de energia estacionária de pequena escala. $A$ membrana/eletrólito utilizada é o Nafion $\AA$, operam em uma faixa de temperatura que pode variar entre 60 a $120{ }^{\circ} \mathrm{C}$, tem alta densidade de energia, pouco peso e pequeno volume e são robustas e resistentes aos choques e vibrações em função do eletrólito sólido.

As desvantagens da PEMFC são: a necessidade da utilização de platina como catalisador da reação eletroquímica, sensibilidade ao $\mathrm{CO}$ e necessidade de gerenciamento de água da membrana evitando ocorrer um desequilíbrio entre a produção e evaporação da água no interior da célula ${ }^{[117-119]}$.

A célula a combustível a ácido fosfórico (PAFC) foi o primeiro tipo a ser comercializado. Os maiores fabricantes dessa tecnologia são as empresas Fuel Cells Corporation, Fuji Electric Corporation, Toshiba Corporation e Mitsubishi Electric Corporation. O eletrólito utilizado é o ácido fosfórico concentrado, operam a temperaturas entre 160 e $220{ }^{\circ} \mathrm{C}$ e pode ser utilizada com combustível tais como hidrocarbonetos leves, gás natural, nafta ou metanol, reformados em $\mathrm{H}_{2}$.

Uma das grandes vantagens dessa célula vem do fato de que, como ela opera a temperaturas mais elevadas, há uma tolerância maior com relação ao 
CO (na faixa de 1 a $1,5 \%$ ), ou seja, o hidrogênio utilizado como combustível pode ser impuro sem que haja desativação do catalisador, no caso, a platina (Pt). Como desvantagens, pode-se citar a geração de baixa corrente, peso elevado e dimensões (comparada aos outros tipos de células) ${ }^{[117-119]}$.

Nas células a combustível de carbonato fundido (MCFC), o eletrólito utilizado é uma combinação de carbonatos alcalinos (lítio, sódio, potássio), que é retida numa matriz cerâmica de aluminato de lítio $\left(\mathrm{LiAlO}_{2}\right)$, operam a uma temperatura na faixa de 600 a $800{ }^{\circ} \mathrm{C}$, para que a condutividade do eletrólito aumente, sendo ideal para aplicações estacionárias de geração tanto de energia elétrica, como térmica (co-geração). São células que podem operar com $\mathrm{H}_{2}, \mathrm{CO}$, gás natural, propano, gases provenientes de aterros, diesel e produtos da gaseificação do carvão.

As MCFC podem ser feitas de metal comum, reduzindo o custo de fabricação, o catalisador (níquel) também é de baixo custo, sendo já desenvolvidas por empresas como Fuel Cell Energy, Brandstofel Nederland, Ansaldo, Hitachi, entre outras. Como desvantagens pode-se citar o fato de o eletrólito ser muito corrosivo, a necessidade de uma fonte de $\mathrm{CO}_{2}$ no catodo para gerar o íon carbonato e a temperatura como diminuidora da vida útil dos componentes ${ }^{[117-119]}$.

As células a combustível de óxido sólido (SOFC) tem como eletrólito um óxido metálico, a zircônia $\left(\mathrm{ZrO}_{2}\right)$ estabilizada com itria $\left(\mathrm{Y}_{2} \mathrm{O}_{3}\right)$, operando a altas temperatura, de 800 a $1000{ }^{\circ} \mathrm{C}$, onde o combustível pode ser reformado no interior da célula, podendo-se por isso utilizar qualquer tipo de combustível primário, tais como os hidrocarbonetos comuns: gás natural, diesel, gasolina, álcool e gás de carvão. Não necessita de bombas e o equipamento é compacto, não requer compressão de ar, o que proporciona maior eficiência, menos ruído e simplicidade.

As altas temperaturas de operação agilizam a cinética com materiais não preciosos e produz calor como um subproduto utilizado em co-geração ou no seu próprio ciclo básico, da mesma forma que na MCFC, bem como tornam essas células insensíveis ao $\mathrm{CO}$ e $\mathrm{CO}_{2}$, mas restringe a escolha quanto aos materiais componentes ${ }^{[117-119]}$..

Um estudo encomendado pelo Ministério de Ciência e Tecnologia (MCT) sobre os investimentos em hidrogênio e células a combustível no Brasil no 
período entre 1999 a 2007 detectou várias entidades de fomento, bem como as de iniciativa pública e privada, atuantes no segmento, ilustradas na FIG.21 com um capital aplicado de aproximadamente US\$ 70 milhões.

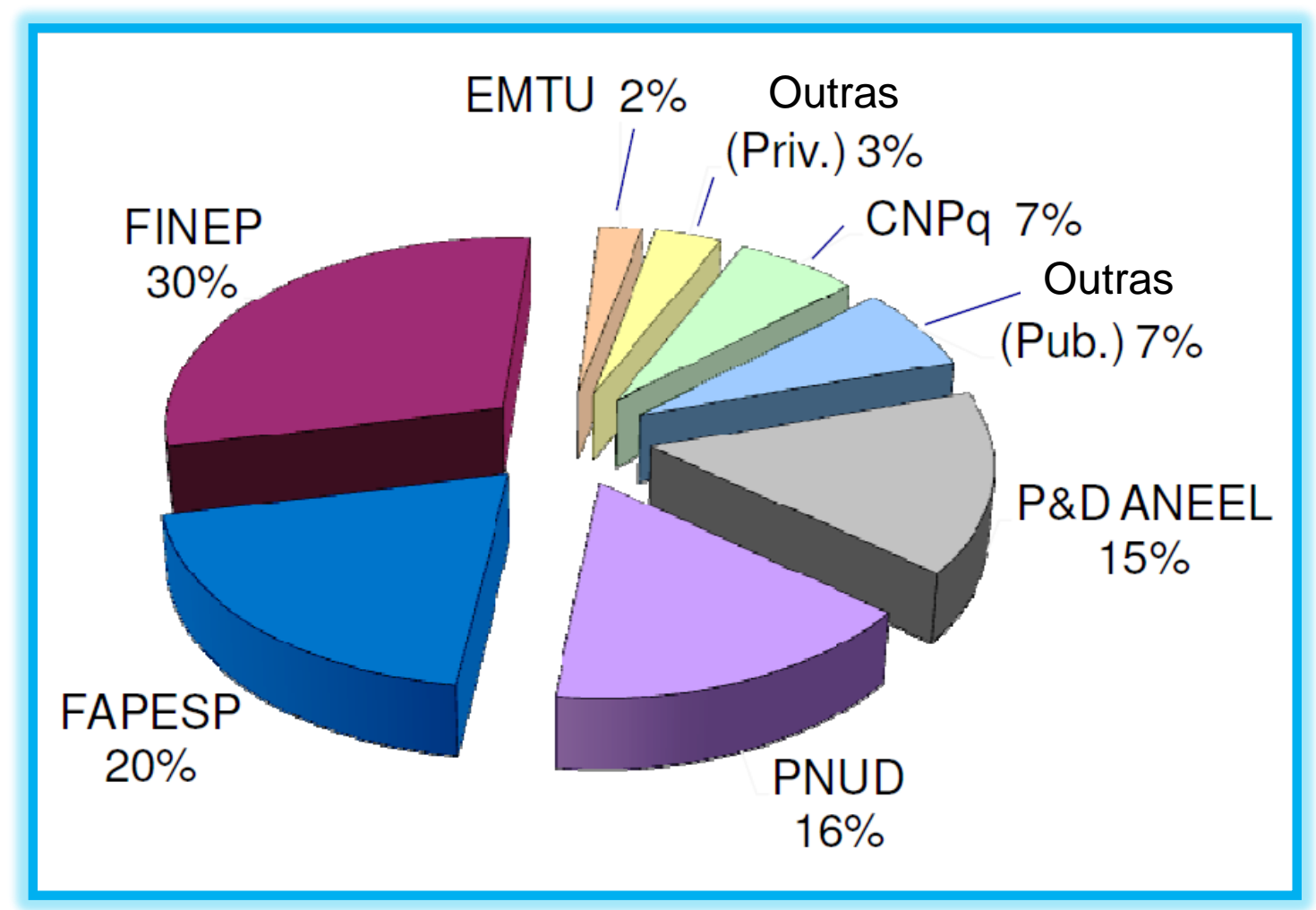

FIGURA 21 - Investimentos em hidrogênio e células a combustível no período de 1999 a 2007.

Fonte: Adaptado de: Matos,M.B., Dissertação de Mestrado, Unicamp, 2009

Atualmente existem vários projetos de automóveis e ônibus movidos a células a combustível a hidrogênio, a exemplo da Peugeot, Honda, BMW, Hyundai na França, Japão, Alemanha e Coréia, respectivamente, com modelos bastante avançados em termos de tecnologia.

No Brasil, esforços têm sido feitos para tornar competitivo os projetos automotivos a hidrogênio. $O$ que se tem de realidade já em funcionamento nas ruas, são os ônibus movidos a hidrogênio, como ilustrados na FIG.22. 

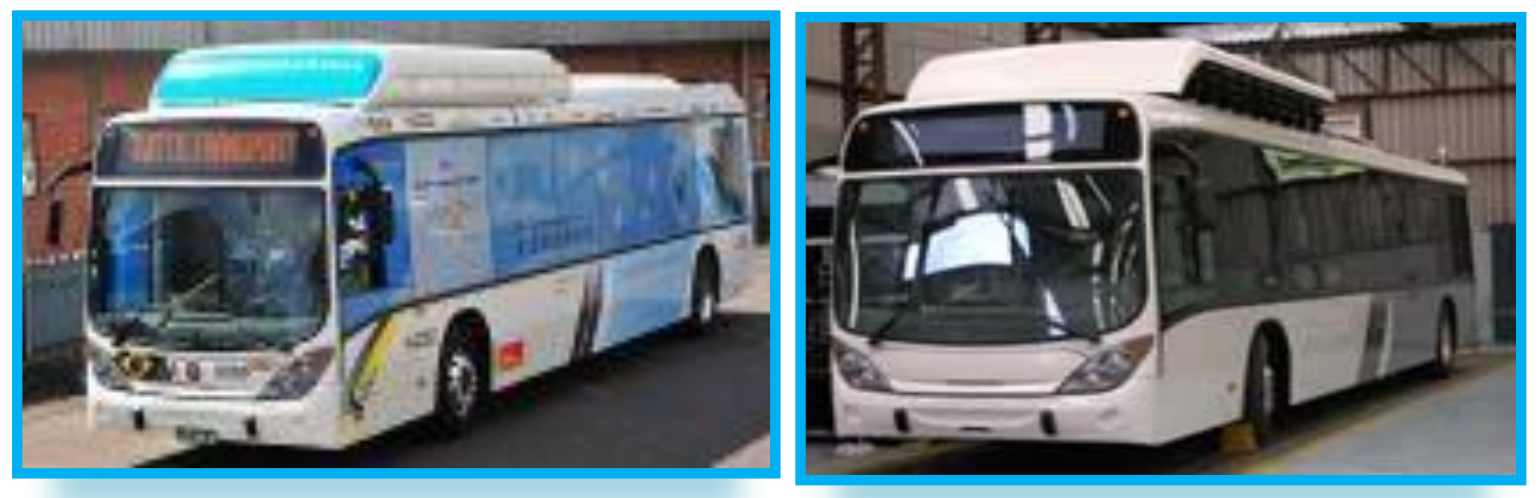

FIGURA 22 - Ônibus movido a hidrogênio circulando em São Bernardo do Campo em São Paulo (esquerda) e na cidade do Rio de Janeiro (direita).

Fonte: http://www.inovacaotecnologica.com.br

Visando a produção de hidrogênio para utilização estacionária, numa perspectiva ambiental no que tange ao aproveitamento de resíduos (biomassa), pode-se lançar mão a várias tecnologias ${ }^{[120-122]}$..

A produção de energia elétrica a partir da pirólise da biomassa é uma alternativa tecnológica onde, o óleo resultante da pirólise pode ser transportado até as centrais elétricas, onde haja um local com um gaseificador e um reformador para a produção de hidrogênio, superando as limitações relativas ao tamanho da planta piloto e os impactos ambientais, bem como utilizar diretamente o hidrogênio obtido em células a combustível.

A proposta de inovação tecnológica neste trabalho foi realizar o processo de pirólise com resíduos da lavoura cafeeira, material proveniente do beneficiamento do fruto que resulta no grão seco utilizado pelas indústrias de torrefação, composto principalmente da "palha", na obtenção de hidrogênio. Paralelamente, obtém-se o bio-óleo que pode também ser utilizado industrialmente. 


\section{MATERIAL E MÉTODOS}

A palha do café, biomassa escolhida para o processo de pirólise para obtenção de hidrogênio no presente trabalho, foi o resíduo do beneficiamento do café tipo Arábica, proveniente da região de Três Pontas, em Minas Gerais, cidade considerada a capital mundial do café, com mais de 70 milhões de cafeeiros plantados, numa área de 24.000 hectares. O município é considerado também o maior produtor nacional ${ }^{[123]}$.

O material foi acondicionado em sacas de material plástico e homogeneizado manualmente, sendo que as amostras, bem como as alíquotas utilizadas na alimentação do reator de pirólise, foram retiradas randomicamente.

\subsection{Caracterização da biomassa}

A palha do café proveniente do processo de beneficiamento da produção do café utilizada neste trabalho foi cedida pela Fazenda Experimental Três Pontas, pertencente à EPAMIG (Empresa de Pesquisa Agropecuária de Minas Gerais). O beneficiamento do café foi feito colocando-se o café cereja para secar ao sol, sendo descascado depois de seco, obtendo-se o grão e a palha do café, conforme esquematizado na FIG.23. 


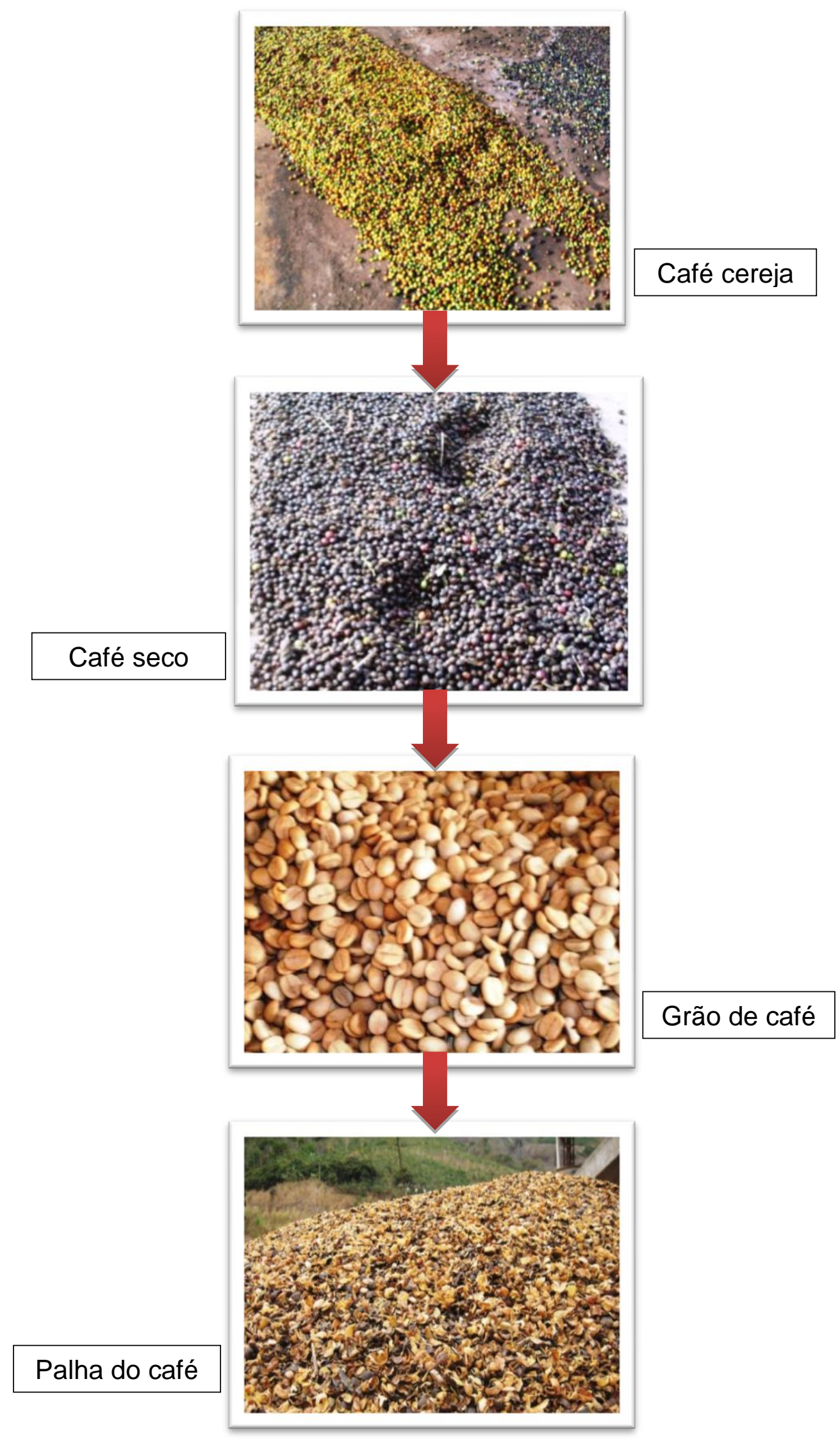

FIGURA 23 - Esquema ilustrativo da obtenção da palha do café na Fazenda Experimental Três Pontas. 
Nos experimentos do processo de pirólise, a palha do café foi utilizada in natura e a caracterização da biomassa foi realizada por meio das técnicas de análise imediata, análise elementar (CHN), análises térmicas (TG/DTG E DSC) e cromatografia a gás acoplada a espectrômetro de massas (GC/MS).

\subsubsection{Análise imediata}

A análise imediata consiste em submeter a amostra a ser analisada a uma sequência de etapas, fornecendo as frações em massa de umidade, materiais voláteis, cinzas e carbono fixo segundo as normas ASTM (American Society for Testing and Materials).

As amostras da palha do café utilizadas para a determinação da análise imediata foram cominuídas em almofariz de porcelana, tamisadas em peneiras granulométricas de 65 mesh, homogeneizadas e os procedimentos feitos em duplicata.

\subsubsection{Determinação do teor de umidade}

Esta medida refere-se ao teor de umidade contido na palha do café.

A amostra foi submetida a um processo de secagem à temperatura de $110{ }^{\circ} \mathrm{C}$ por um período de 2 horas, resfriada, acondicionada em dessecador e posteriormente pesada, repetindo-se o processo até que se obtivesse um valor constante em peso da amostra. Uma vez estabilizada a massa da amostra, pôde-se determinar o teor de umidade por diferença entre as massas inicial e final (ASTM E 871-82).

A secagem do material foi feita em estufa para esterilização e secagem da marca Nova Ética modelo 400, com temperatura de circulação de ar ambiente $+15{ }^{\circ} \mathrm{C}$ a $200{ }^{\circ} \mathrm{C}$, com controlador digital de 4 dígitos com resolução de $0,1{ }^{\circ} \mathrm{C}$, certificada pelo laboratório de metrologia Contemp, sob o n ${ }^{0}$ LMC 4574-10.

\subsubsection{Determinação do teor do material volátil}

A fração de materiais voláteis (hidrocarbonetos e gases, tais como, hidrogênio, monóxido de carbono e metano) foi determinada a partir da amostra 
isenta de umidade, que é levada a um forno tipo mufla à temperatura de $950{ }^{\circ} \mathrm{C}$ durante 6 minutos, resfriada, acondicionada em dessecador, tendo sua massa final determinada por pesagem em balança analítica (ASTM D 872-82).

A pesagem do material foi feita em balança analítica eletrônica digital da marca Quimis, modelo Q500L210C, capacidade máxima de $210 \mathrm{~g}$ e mínima de $1 \mathrm{mg}$, precisão de 0,1 mg, com verificação Inmetro $n^{0}$ 0-963-914-7.

\subsubsection{Determinação do teor de cinzas}

O teor de cinzas foi determinado a partir da amostra isenta de umidade, que foi submetida a um processo de calcinação em um forno tipo mufla préaquecido à temperatura de $750{ }^{\circ} \mathrm{C}$, calcinada por 2 horas, resfriada, acondicionada em dessecador e sua massa final determinada por pesagem em balança analítica (ASTM D 1102-84).

O equipamento utilizado no processo foi um forno tipo mufla digital da marca Quimis, modelo Q318M24, a temperatura de trabalho de 300 a $1200{ }^{\circ} \mathrm{C}$.

\subsubsection{Determinação do teor de carbono fixo}

A fração do teor de carbono fixo é determinada pela diferença entre a soma das massas das duas etapas anteriores, ou seja:

$$
\mathrm{C}_{\mathrm{fixo}}=100 \%-(\text { mat. volátil }+ \text { cinzas }) \%
$$

A partir dos resultados da análise imediata, mais especificamente os teores de materiais voláteis e carbono fixo, pode-se inferir o cálculo do Poder Calorífico Superior (PCS) da amostra.

O Poder Calorífico é a quantidade de energia interna por unidade de massa, ou volume no caso dos gases, contida em um determinado material; é calculado em $\mathrm{kcal} / \mathrm{kg}$ e foi determinado pelas fórmulas ${ }^{[124]}$ :

$$
\begin{array}{ll}
\text { PCS }=8239,47-32,95(\mathrm{mv}) & \text { onde, } \mathrm{mv}=\text { material volátil } \\
\mathbf{P C S}=4934,43+33,27(\mathrm{cf}) & \text { onde }, \mathrm{cf}=\text { carbono fixo }
\end{array}
$$




\subsubsection{Análise elementar}

A análise elementar determina a composição percentual dos elementos constituintes da biomassa, principalmente carbono, hidrogênio e nitrogênio (CHN).

As amostras preparadas para a determinação da análise elementar foram cominuídas em almofariz de porcelana, tamisadas em peneira granulométrica de 65 mesh, secadas em estufa a $105^{\circ} \mathrm{C}$ durante $2 \mathrm{hs}$ e os procedimentos realizados em triplicatas.

Alíquotas de 2 a $3 \mathrm{mg}$ foram pesadas em uma balança analítica de alta precisão $(0,00001 \mathrm{~g})$, marca Sartorius, modelo MC $210 \mathrm{~S}$ e posteriormente analisadas em equipamento Perkin Elmer Elemental Analyser $2400 \mathrm{CHN}$, ilustrado na FIG.24.

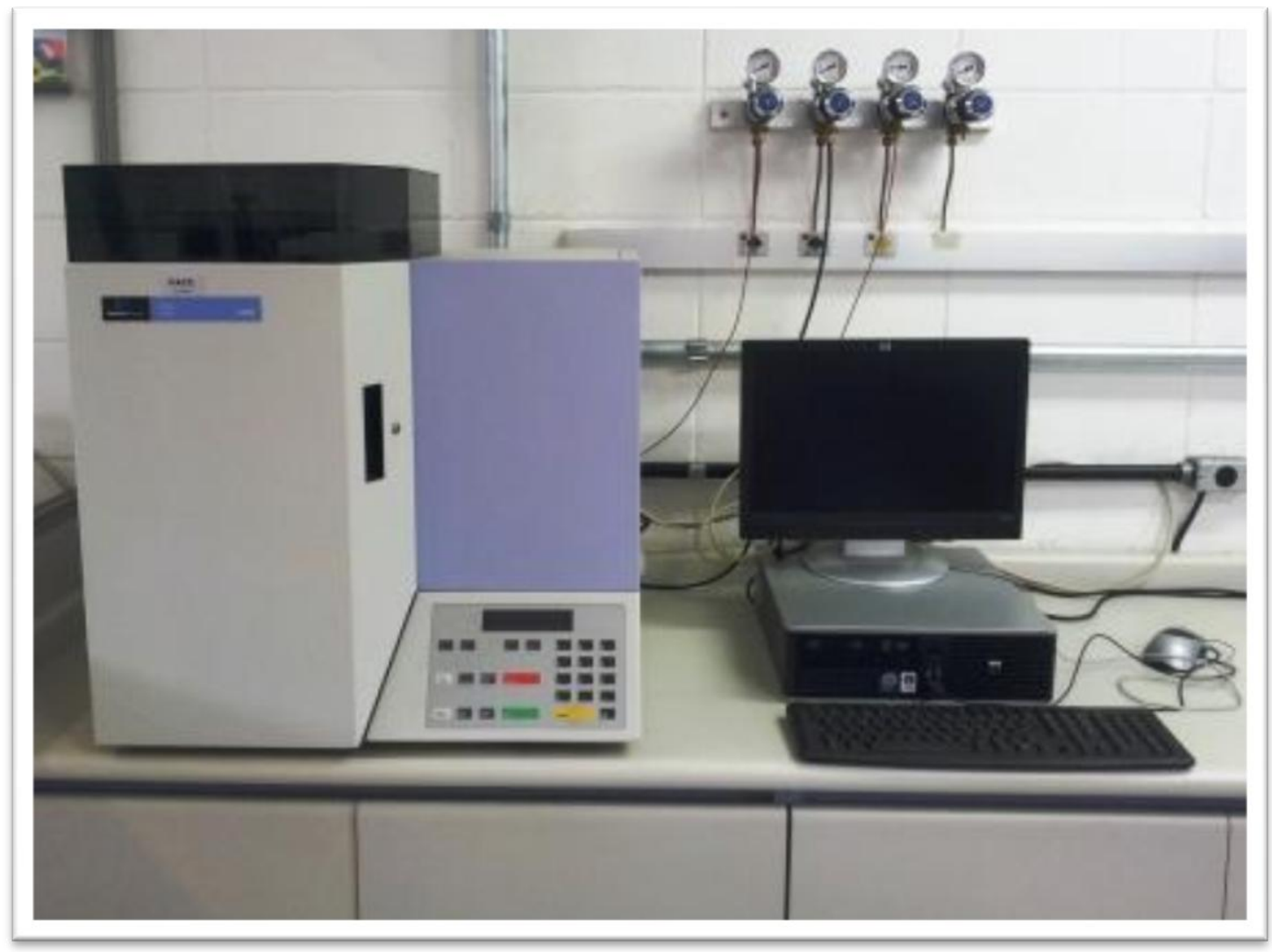

FIGURA 24 - Equipamento de análise elementar. 


\subsubsection{Termogravimetria/Termogravimetria Derivada (TG/DTG) e Calorimetria Exploratória Diferencial (DSC)}

A técnicas termoanalíticas, TG/DTG e DSC, foram utilizadas como ferramentas para determinar o comportamento térmico da palha do café durante os processos de conversão térmica em atmosfera inerte ou oxidante. Estas técnicas são eficazes para a determinação da estabilidade térmica desse material.

As curvas TG/DTG foram realizadas em uma termobalança modelo TGA-51, marca Shimadzu, utilizando atmosfera dinâmica de ar com vazão de $50 \mathrm{~mL} \mathrm{~min}^{-1}$, intervalo de temperatura de $25-900{ }^{0} \mathrm{C}$, com razão de aquecimento (ß) de $10{ }^{0} \mathrm{C} \mathrm{min}^{-1}$ e massa de amostra de $25 \mathrm{mg}$.

As curvas DSC foram obtidas em uma célula DSC-50, marca Shimadzu utilizando atmosfera dinâmica de nitrogênio $\left(\mathrm{N}_{2}\right)$ com vazão de $100 \mathrm{~mL} \mathrm{~min}{ }^{-1}$, intervalo de temperatura da ambiente até $550{ }^{\circ} \mathrm{C}$ com razão de aquecimento $(\beta)$ de $10{ }^{0} \mathrm{C} \mathrm{min}{ }^{-1}$ e massa de amostra de $2 \mathrm{mg}$.

Na FIG.25 apresentam-se os equipamentos utilizados para as medidas de TG/DTG e DSC, das amostras da palha interna, externa e da mistura das palhas do café.
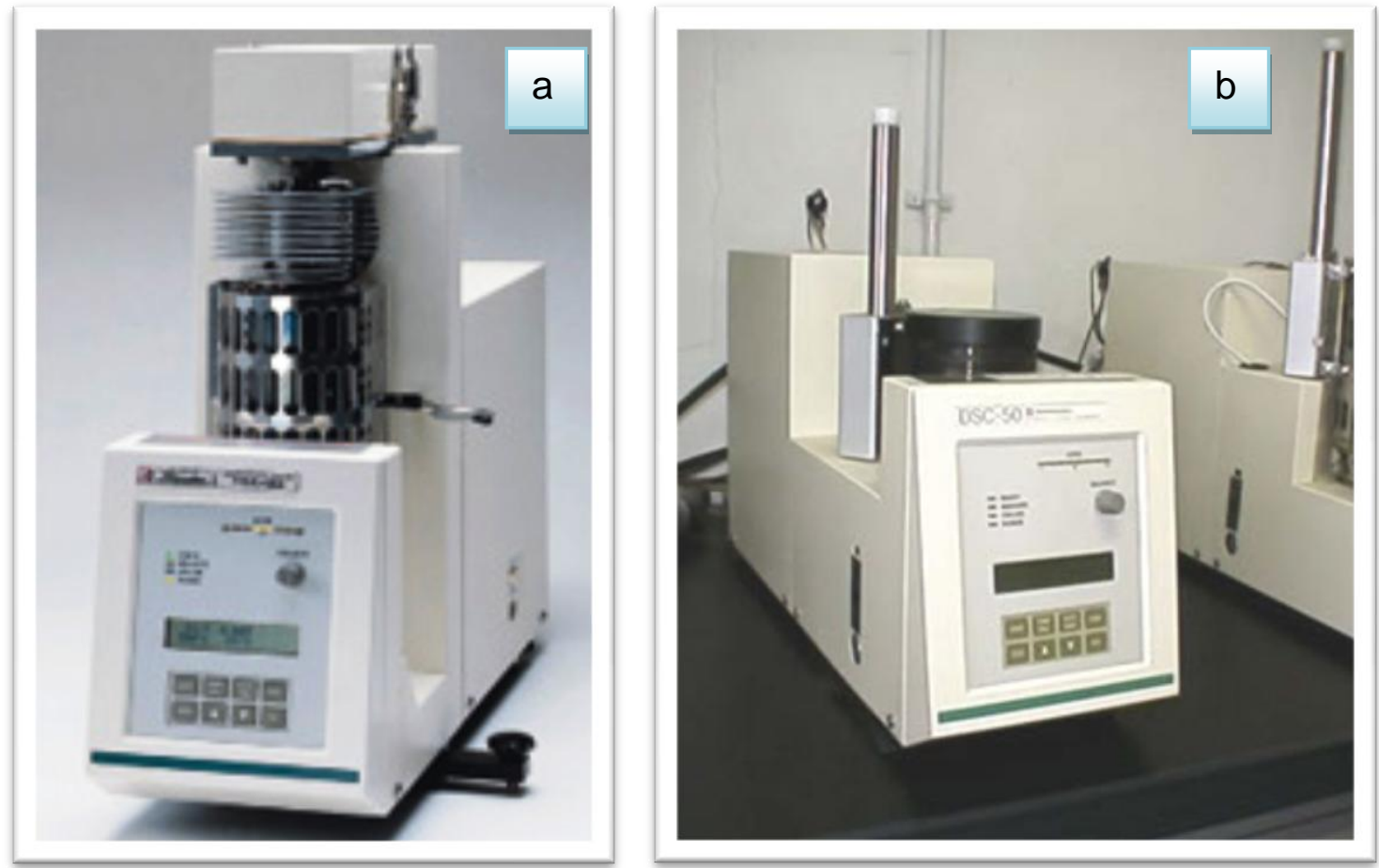

FIGURA 25 - Equipamentos TGA-51 (a) e DSC-50 (b) utilizados para a determinação do comportamento térmico da biomassa do café. 
A palha do café in natura é uma mistura das partes interna e externa que envolvem o grão. Este apresenta um envoltório de cor clara (palha interna) mais leve e quebradiça, o qual está revestido por uma camada de cor escura, a qual se define como palha externa, conforme FIG.26.

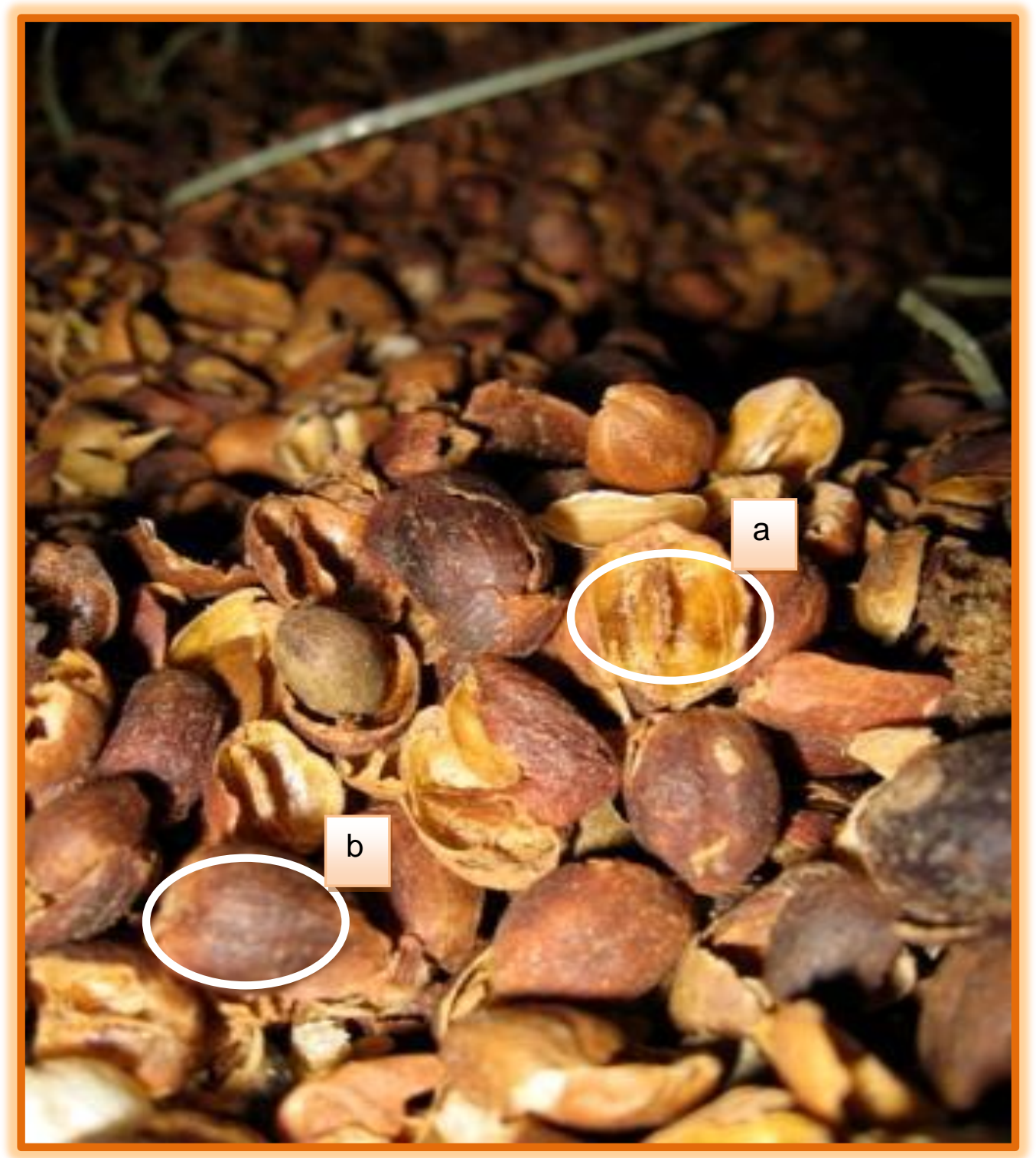

FIGURA 26 - llustração que mostra detalhes das palhas interna (a) e externa (b) do café.

As palhas internas e externas foram analisadas separadamente, pois em algumas fazendas mecanizadas, na etapa de beneficiamento do grão do café, há uma estocagem em diferentes "pilhas" das palhas interna e externa, conforme 
mostrado na FIG.27, o que poderia ser útil no caso em que as análises inferissem em resultados muito diferentes, principalmente no que diz respeito ao poder calorífico, o que define se um determinado material pode ser utilizado como biomassa energética.

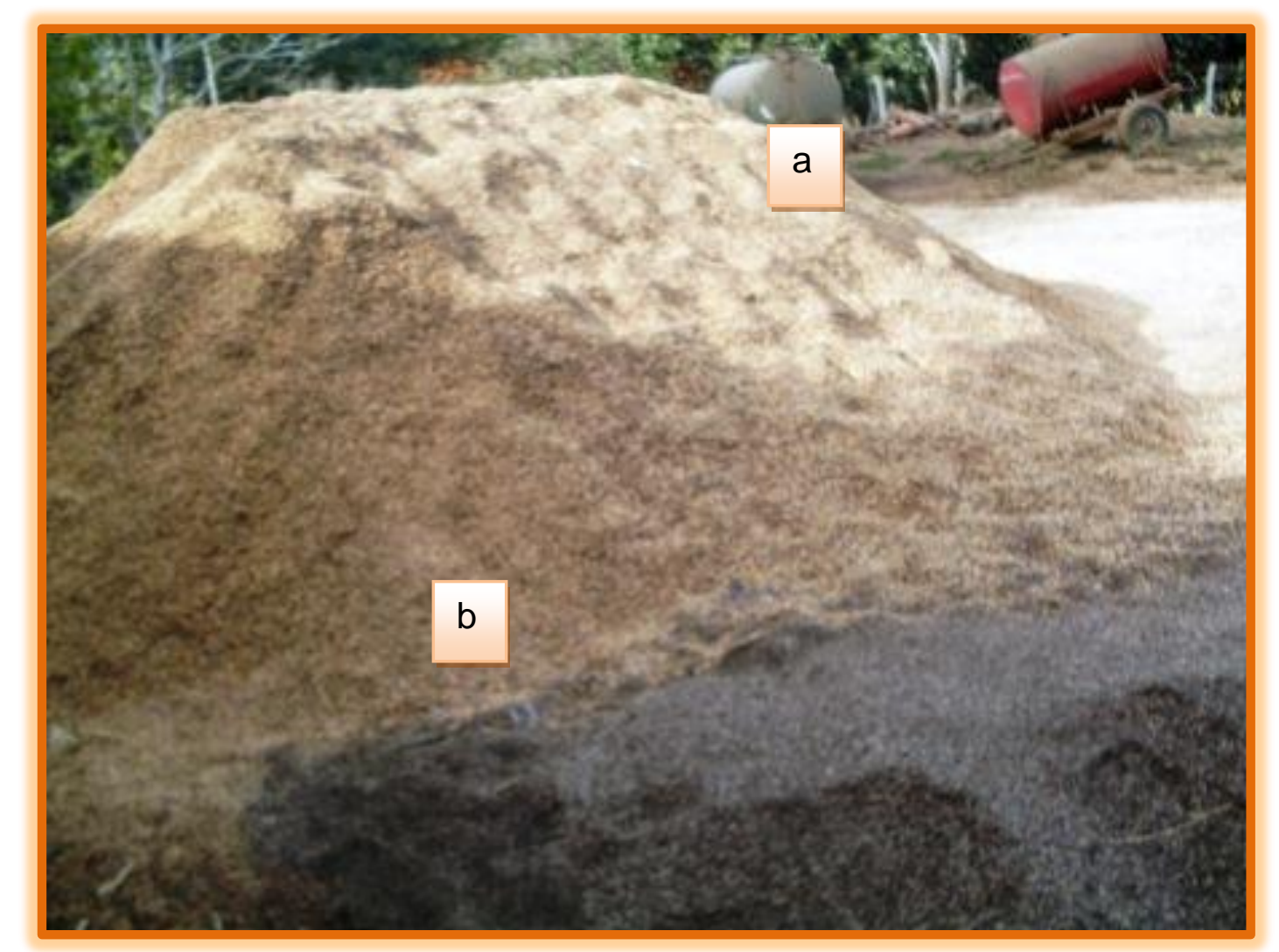

FIGURA 27 - Disposição das diferentes "pilhas" das palhas interna (a) e externa (b) do café, em fazenda com mecanização na etapa de beneficiamento.

A fim de caracterizar as camadas (interna e externa) isoladas, separouse manualmente a palha interna da externa, que posteriormente foram cominuídas em almofariz de porcelana e tamisadas em peneira granulométrica de 65 mesh. O mesmo procedimento foi feito para a mistura das palhas interna e externa. 


\subsubsection{Cromatografia a gás acoplada a espectômetria de massa (GC/MS)}

A identificação dos compostos orgânicos presentes na palha do café foram realizadas em um Cromatógrafo a gás acoplado a um Espectrômetro de massa (GC-MS), marca Shimadzu, modelo GCMS - QP5000. A temperatura do injetor foi de $230{ }^{\circ} \mathrm{C}$. A coluna capilar utilizada foi a DB-5 de dimensões $29,7 \mathrm{~m} \mathrm{x}$ $0,25 \mathrm{~mm} \times 0,25 \mu \mathrm{m}$ (comprimento $\times$ diâmetro $\times$ espessura).

A palha do café foi cominuída em almofariz de porcelana e tamisada em peneira granulométrica de 65 mesh. Em seguida foram preparadas duas amostras: uma com a palha do café in natura e outra com a palha do café seca.

Para a secagem da amostra utilizou-se uma estufa a uma temperatura de $80{ }^{\circ} \mathrm{C}$ durante 30 minutos; a amostra depois de seca foi colocada em dessecador com sílica para mantê-la isenta de umidade.

Para as medidas de GC/MS, foi necessário um pré-tratamento das amostras da palha do café, solubilizando-as em solventes orgânicos: clorofórmio $\left(\mathrm{CHCl}_{3}\right)$, hexano $\left(\mathrm{C}_{6} \mathrm{H}_{14}\right)$, acetonitrila $\left(\mathrm{CH}_{3} \mathrm{CN}\right)$ e diclorometano $\left(\mathrm{CH}_{2} \mathrm{Cl}_{2}\right)$.

Esse processo foi realizado pesando-se $100 \mathrm{mg}$ da palha do café e colocando-as em um recipiente contendo $5 \mathrm{~mL}$ do solvente, relação massa/volume suficiente para determinar os componentes químicos presentes nesse material, com tempo de extração de 30 minutos. Após esse período, essa mistura foi filtrada e o sobrenadante foi diluído até concentrações adequadas para que fosse possível fazer as medidas no GC/MS. Apenas $1 \mu \mathrm{L}$ de cada amostra foi injetado no módulo ilustrado na FIG.28. 


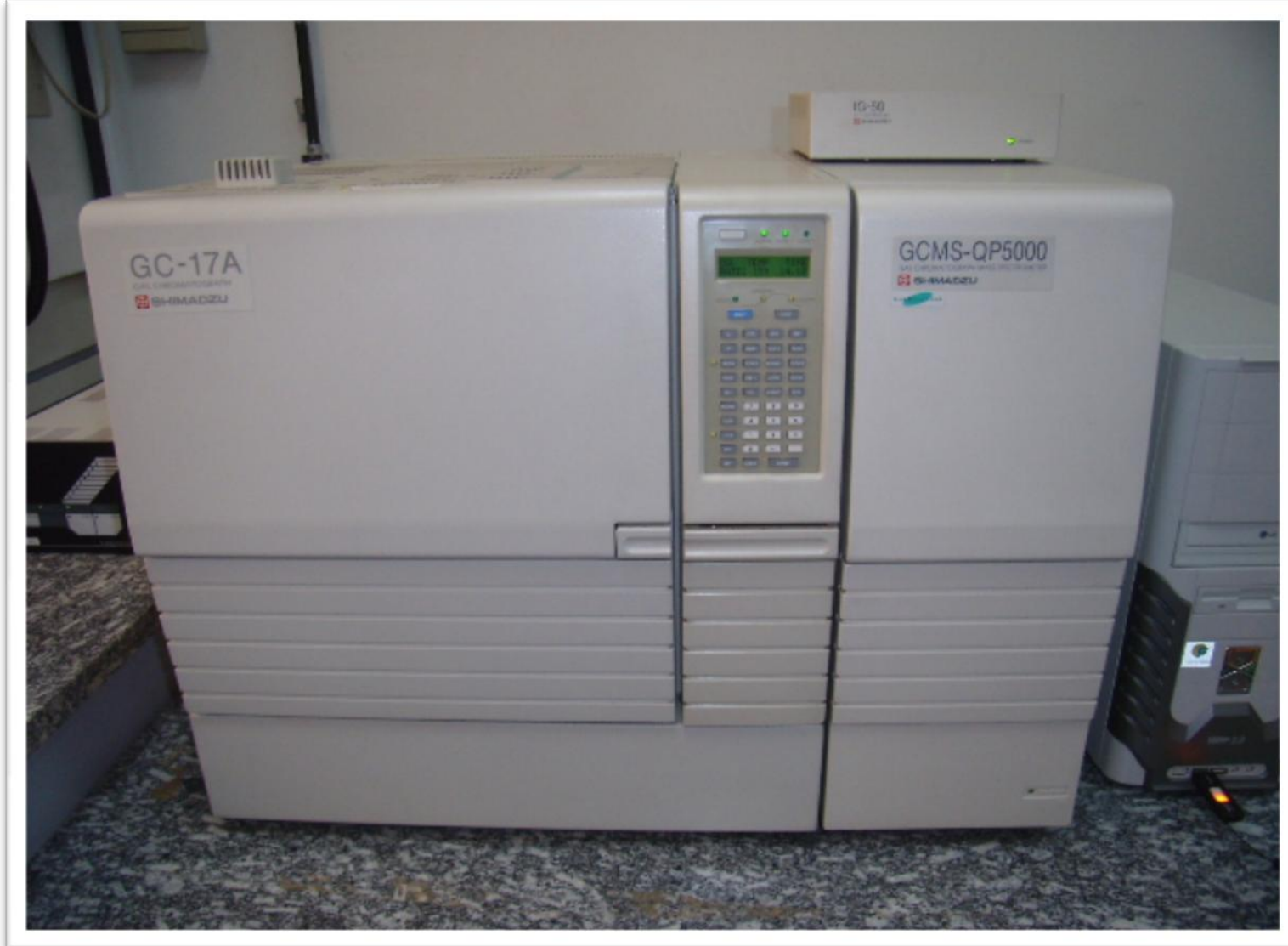

FIGURA 28 - Equipamento de GC/MS utilizado para a identificação dos compostos químicos presentes na biomassa da palha do café.

\subsection{Reator de pirólise}

O reator utilizado no processo de pirólise da biomassa da palha do café foi construído nas instalações do Instituto de Pesquisas Energéticas e Nucleares (IPEN), conforme desenho do projeto mostrado na FIG.29. 


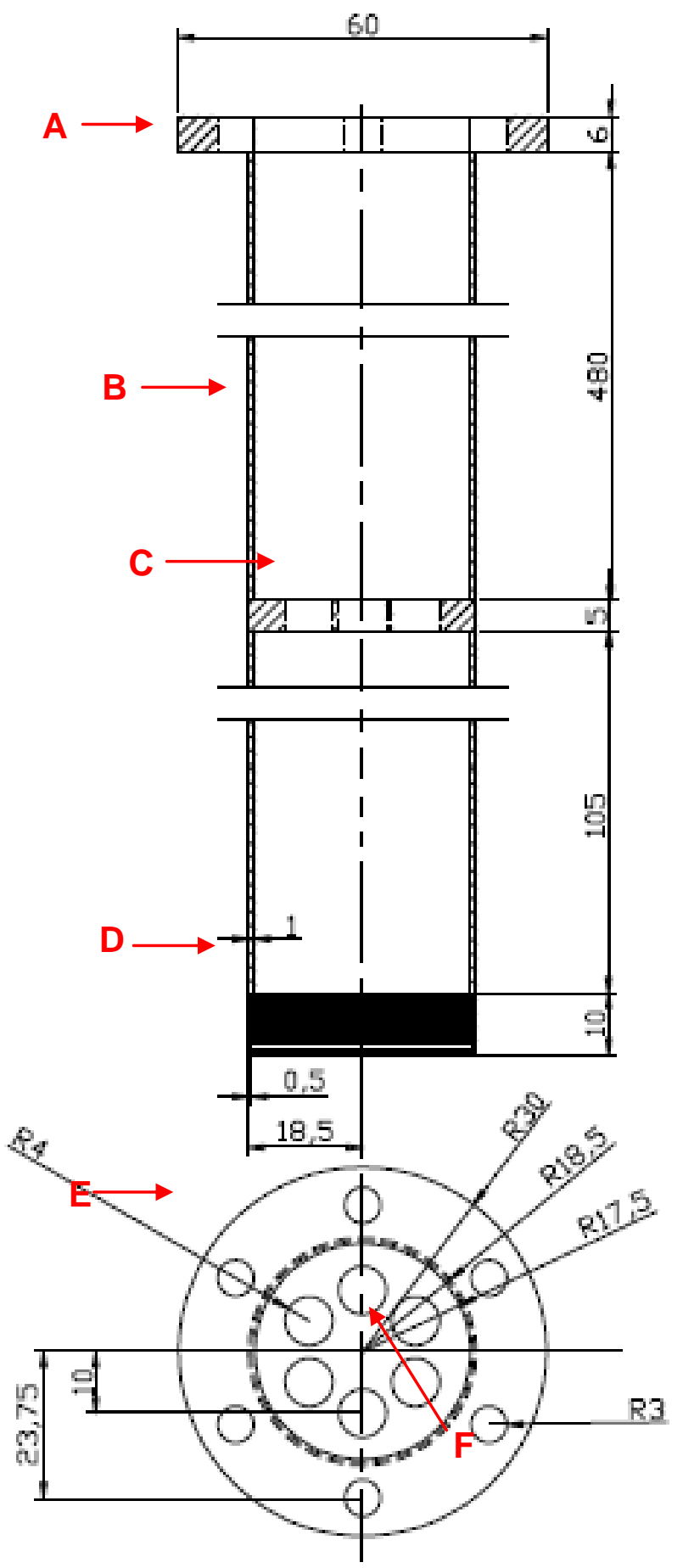

Projeto: Reator de Pirólise

A - Sistema de flange

B - Camisa do reator

C - Corpo do reator

D - Sistema de aquecimento (grelha)

E - Vista superior do sistema de flange

F - Vista superior do sistema de aquecimento (grelha)

(medidas em $\mathrm{mm}$ )

FIGURA 29 - Projeto piloto do reator de pirólise do IPEN. 
Esse equipamento é constituído de duas partes: uma interna e outra externa. A parte interna que constitui o corpo do reator foi feita de aço inox 304, flangeado na parte superior onde foi acoplado um condensador, seguido de um recipiente coletor da fração líquida e dos gases não condensáveis do processo.

A parte externa constitui-se de um encamisamento em aço inox 304, no qual foi soldado uma grelha na extremidade inferior, com um orifício para 0 acendimento e condução de calor ao sistema e a essa grelha foi conectado um maçarico.

Todo o sistema externo foi envolvido em lã de vidro com uma capa de material retentor de temperatura. Na FIG.30 é apresentado o sistema completo montado para o processo de pirólise.

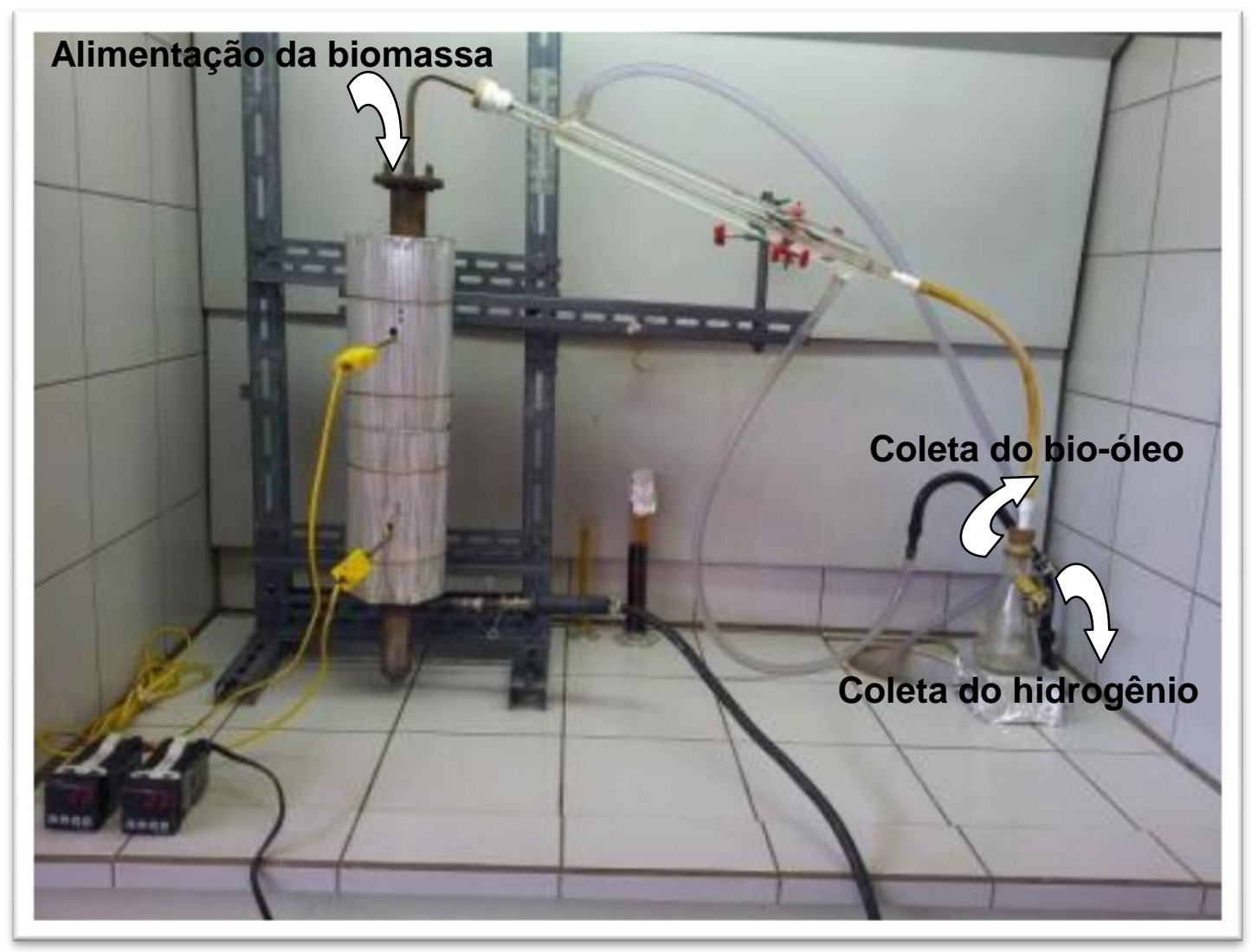

FIGURA 30 - Sistema completo montado para o processo de pirólise (IPEN).

O reator de pirólise foi alimentado com $54 \mathrm{~g}$ da palha do café por meio de bateladas, uma vez que o sistema é totalmente fechado. Esse valor foi calculado levando-se em consideração a literatura que diz que somente $2 / 3$ do reator deve ser carregado. Mesmo assim, bateladas com $63 \mathrm{~g}$ da palha do café 
foram processadas, mas não foram atingidas temperaturas de operação altas o suficiente para que se obtivesse hidrogênio no produto gasoso. O mesmo aconteceu com a variação do tamanho da partícula, que não apresentou diferenças significativas nos resultados.

A temperatura de operação foi medida por dois termopares e a pressão de alimentação do gás de aquecimento, o GLP (gás liquefeito de petróleo), controlada por um manômetro Famabrás modelo FSA 62/1 (GLP 0/7 kgf/cm ${ }^{2}$ ). O fluxo do gás foi mantido em $0,56 \mathrm{Ndm}^{3} / \mathrm{min}$, pois a um valor menor a chama apagava e a maior gerava vazamentos nas conexões. Um rotâmetro para GLP marca Omel, modelo 173.061 foi utilizado para a medição do controle de fluxo do GLP.

Nas FIG.31, 32, 33, 34 e 35 pode-se observar melhor os detalhes do reator de pirólise do IPEN.
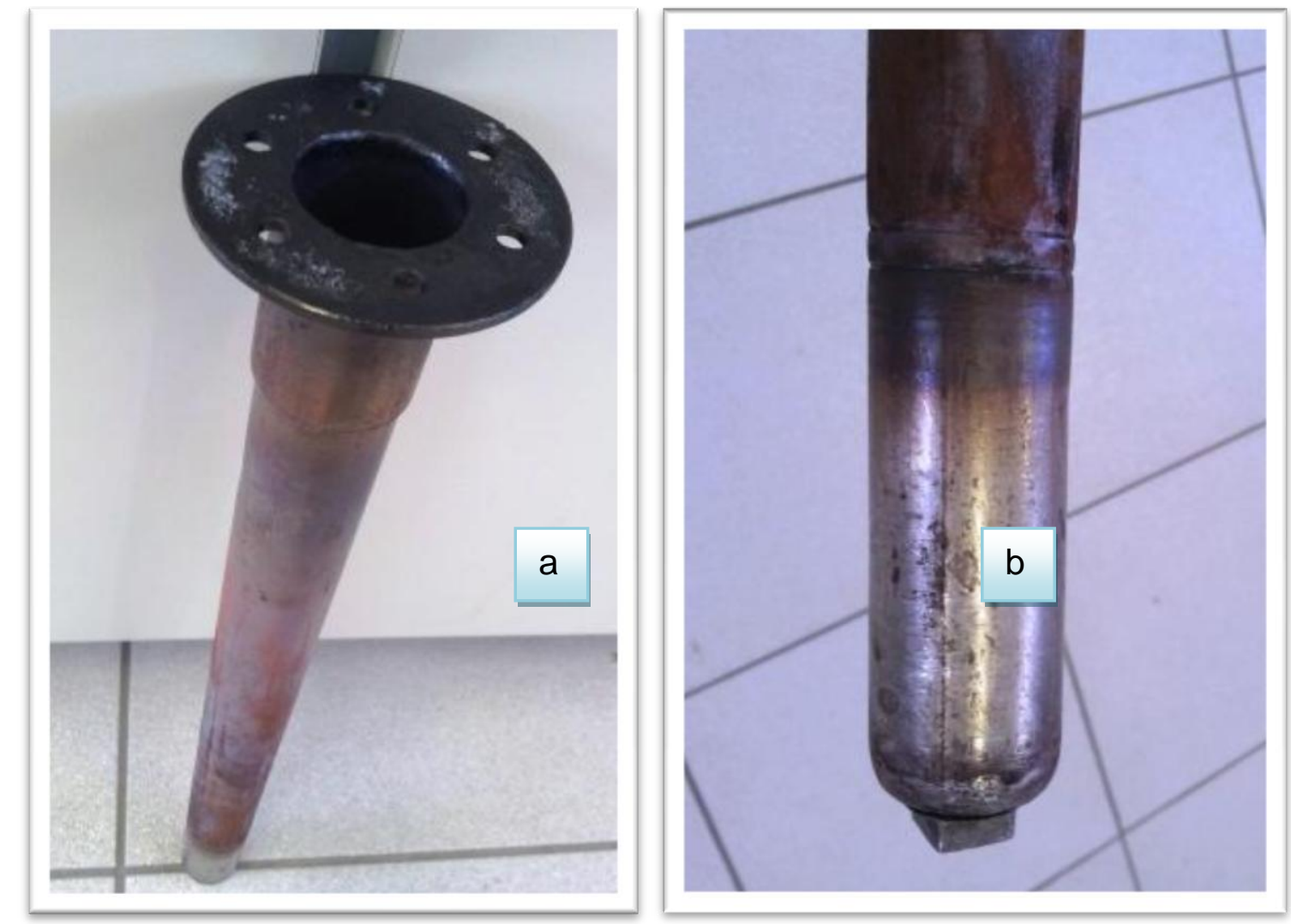

FIGURA31 - Corpo do reator acoplado ao flange (a) e detalhe da parte inferior totalmente fechada (b) do reator de pirólise. 


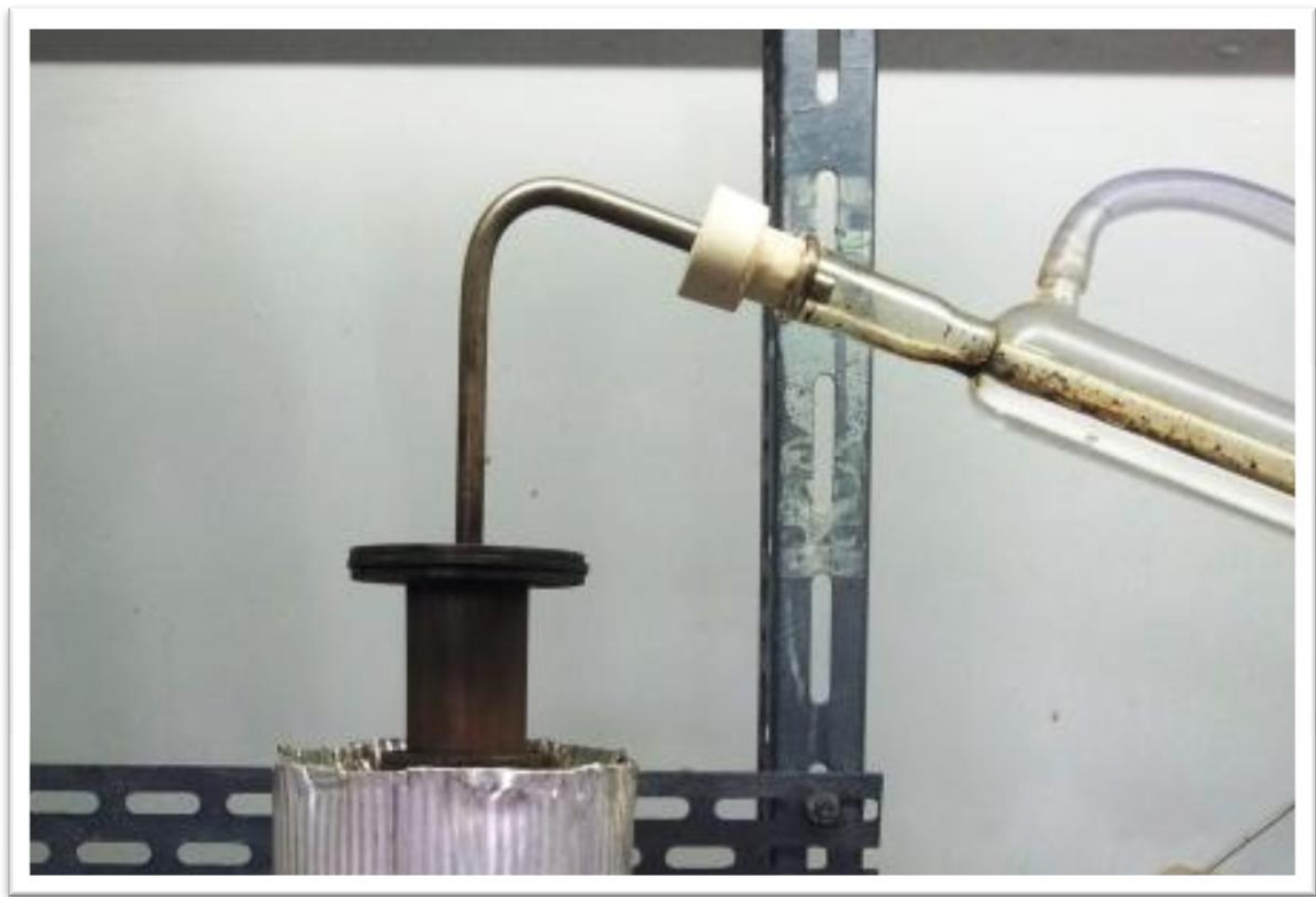

FIGURA 32 - Sistema de flangeamento do reator de pirólise acoplado ao condensador.

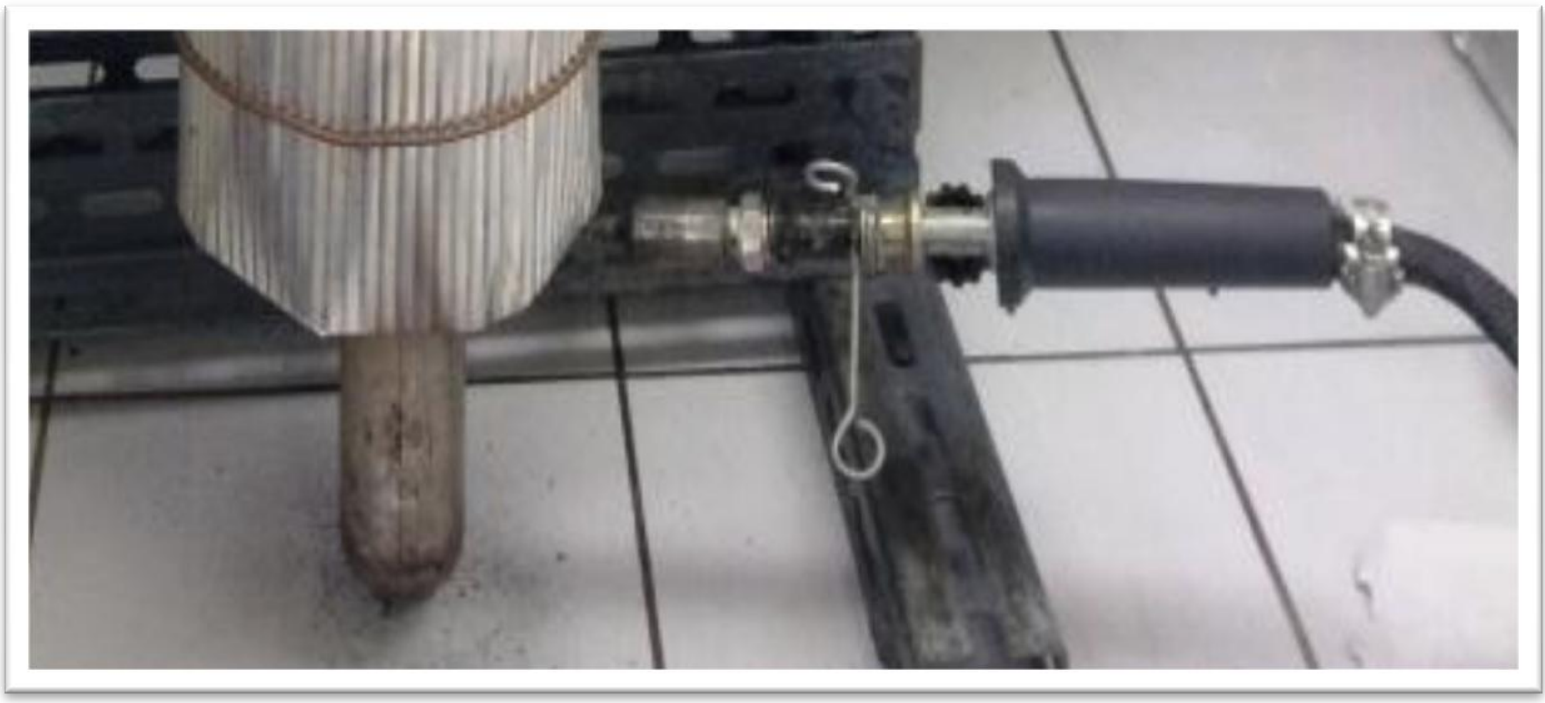

FIGURA 33 - Sistema inferior do reator de pirólise acoplado ao maçarico. 


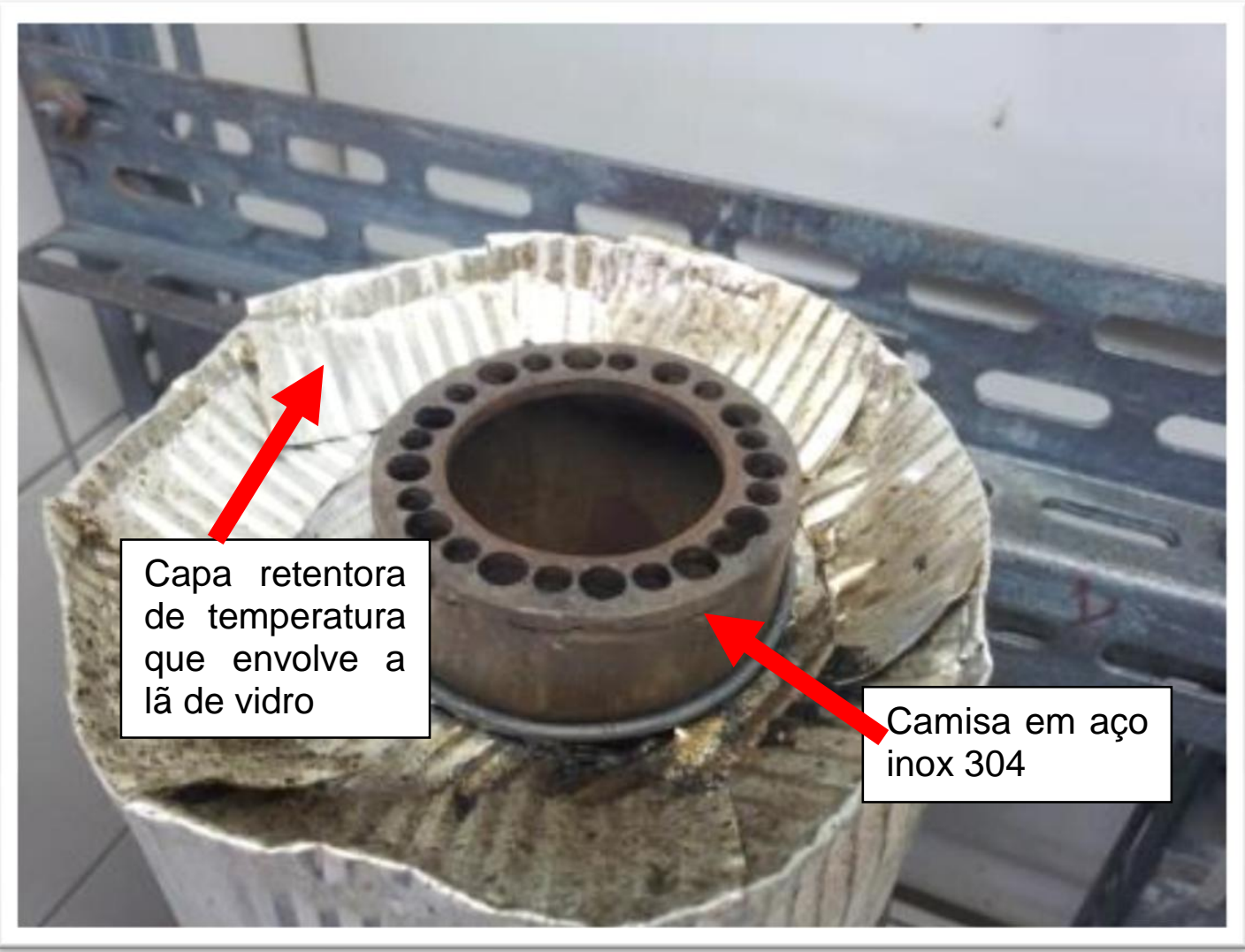

FIGURA 34 - Detalhe do encamisamento do reator de pirólise.

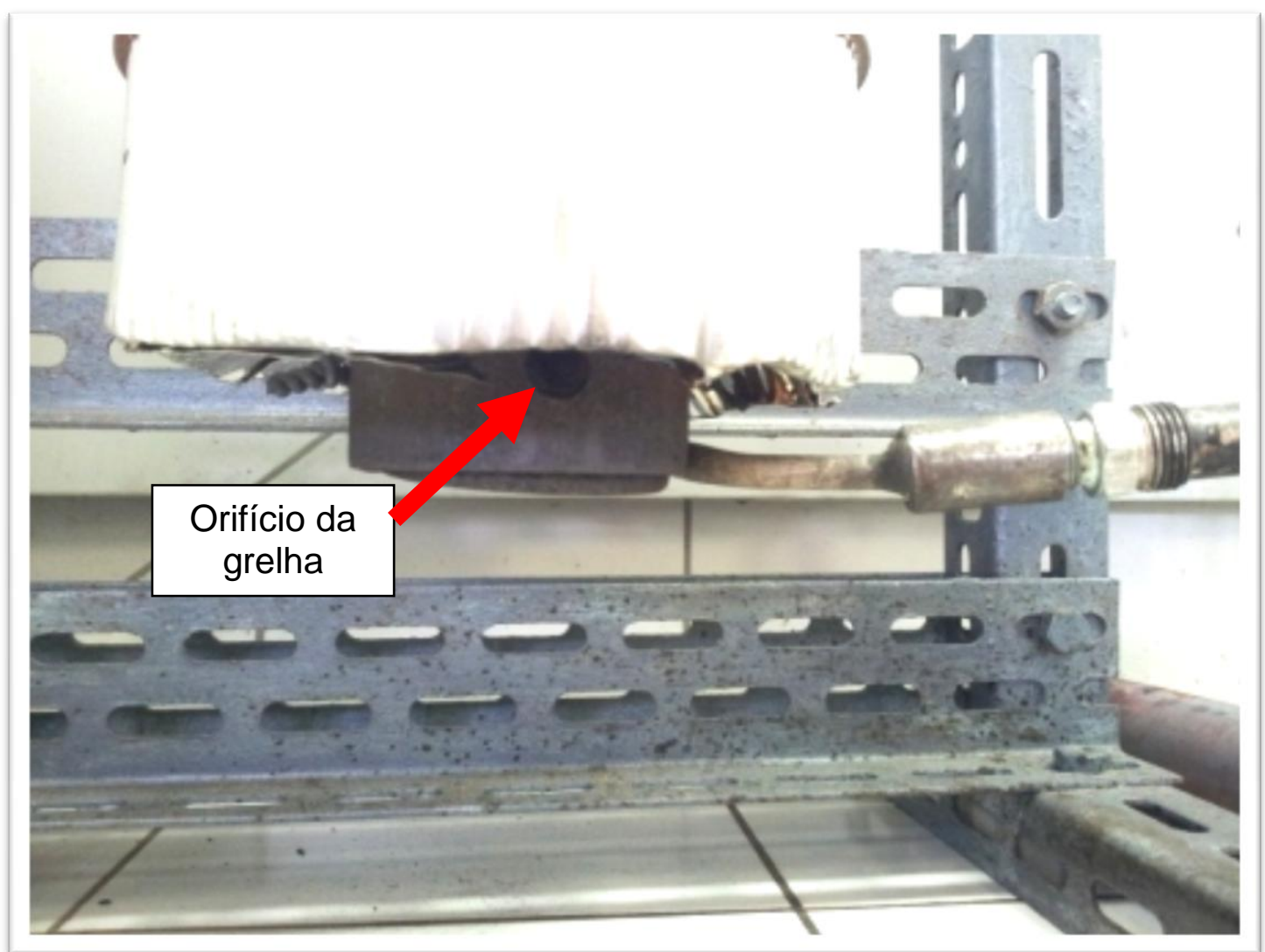

FIGURA 35 - Detalhe do orifício da grelha por onde se acende o reator de pirólise. 


\subsection{Estudo dos principais parâmetros de processo}

\subsubsection{Pressão de alimentação do gás de aquecimento}

Nesta etapa estudou-se a influência da variação da pressão de alimentação do gás de aquecimento (GLP) ideal para o sistema, aplicando-se pressões de 4,8,5,5 e $6,4 \mathrm{kgf} / \mathrm{cm}^{2}$.

\subsubsection{Taxa de aquecimento}

Nesta etapa verificou-se a evolução da taxa de aquecimento em relação ao tempo, registrada através dos termopares inseridos na camisa do reator de pirólise, nas diferentes bateladas de palha do café.

\subsubsection{Temperatura de operação do reator de pirólise}

Nesta etapa estudou-se a evolução das temperaturas no reator de pirólise em função do tempo nas diferentes bateladas de palha do café.

\subsubsection{Rendimento gravimétrico}

Por meio do controle dos parâmetros acima, foi possível a determinação do rendimento gravimétrico do processo de pirólise da palha do café, que é a relação entre a massa (cinzas) ou volume (bio-óleo) produzidos, pela massa inicial (palha do café).

$$
R G=\left[M_{\text {final }} \text { ou } V_{\text {final }} / M_{\text {inicial }}\right] \times 100 \%
$$




\subsection{Caracterização dos produtos obtidos no processo de pirólise}

Os processos de pirólise, de um modo geral, geram três produtos principais: sólido, líquido e gasoso. $\mathrm{Na}$ pirólise da palha de café, as caracterizações dos produtos gerados foram realizadas pelas medidas de análise elementar (cinzas), GC/MS (bio-óleo) e Cromatografia à gás (hidrogênio).

\subsubsection{Análise elementar das cinzas}

A análise elementar das cinzas provenientes do produto da pirólise (FIG. 36) foi realizada nos mesmos moldes de preparação e execução da caracterização da biomassa da palha de café in natura: as cinzas foram cominuídas em almofariz de porcelana, tamisadas em uma peneira granulométrica de 65 mesh e os procedimentos realizados em triplicata.

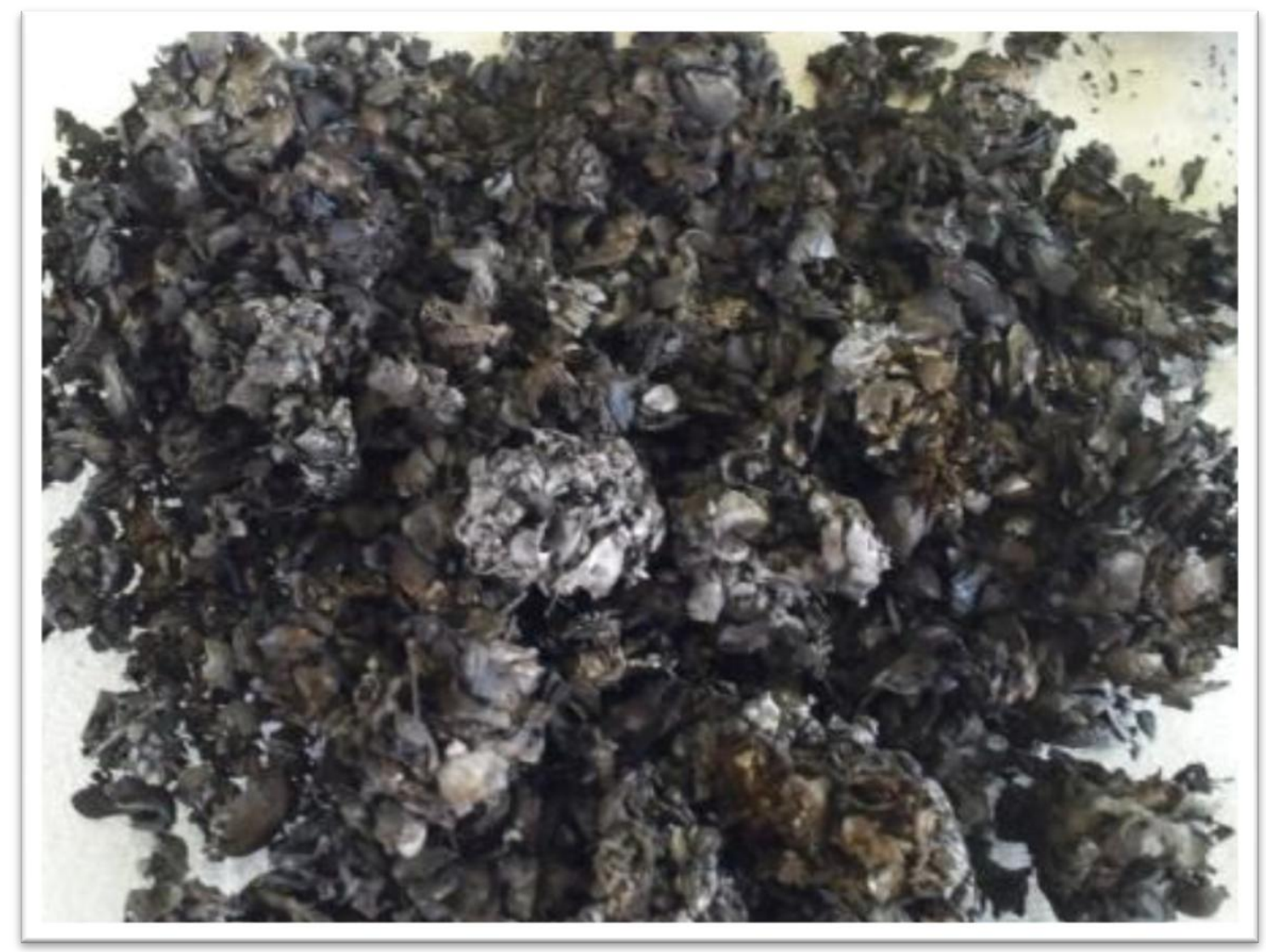

FIGURA 36- Ilustração das cinzas provenientes do produto da pirólise. 


\subsubsection{Caracterização do bio-óleo por GC/MS}

\subsubsection{Bio-óleo}

As medidas do bio-óleo utilizando a técnica GC/MS foram realizadas pelo mesmo equipamento a que foi submetida a biomassa da palha do café. $A$ temperatura do injetor foi de $260{ }^{\circ} \mathrm{C}$. A coluna capilar utilizada foi a DB-5, com programação de 40 a $260{ }^{\circ} \mathrm{C}$ e com tempo de eluição de 20,83 min.

As amostras de bio-óleo foram preparadas a um fator de diluição 1:10000 em solvente orgânico diclorometano $\left(\mathrm{CH}_{2} \mathrm{Cl}_{2}\right)$ como mostrado no funil de separação da FIG.37, e tomadas alíquotas de $1 \mu \mathrm{L}$ para injeção no módulo.

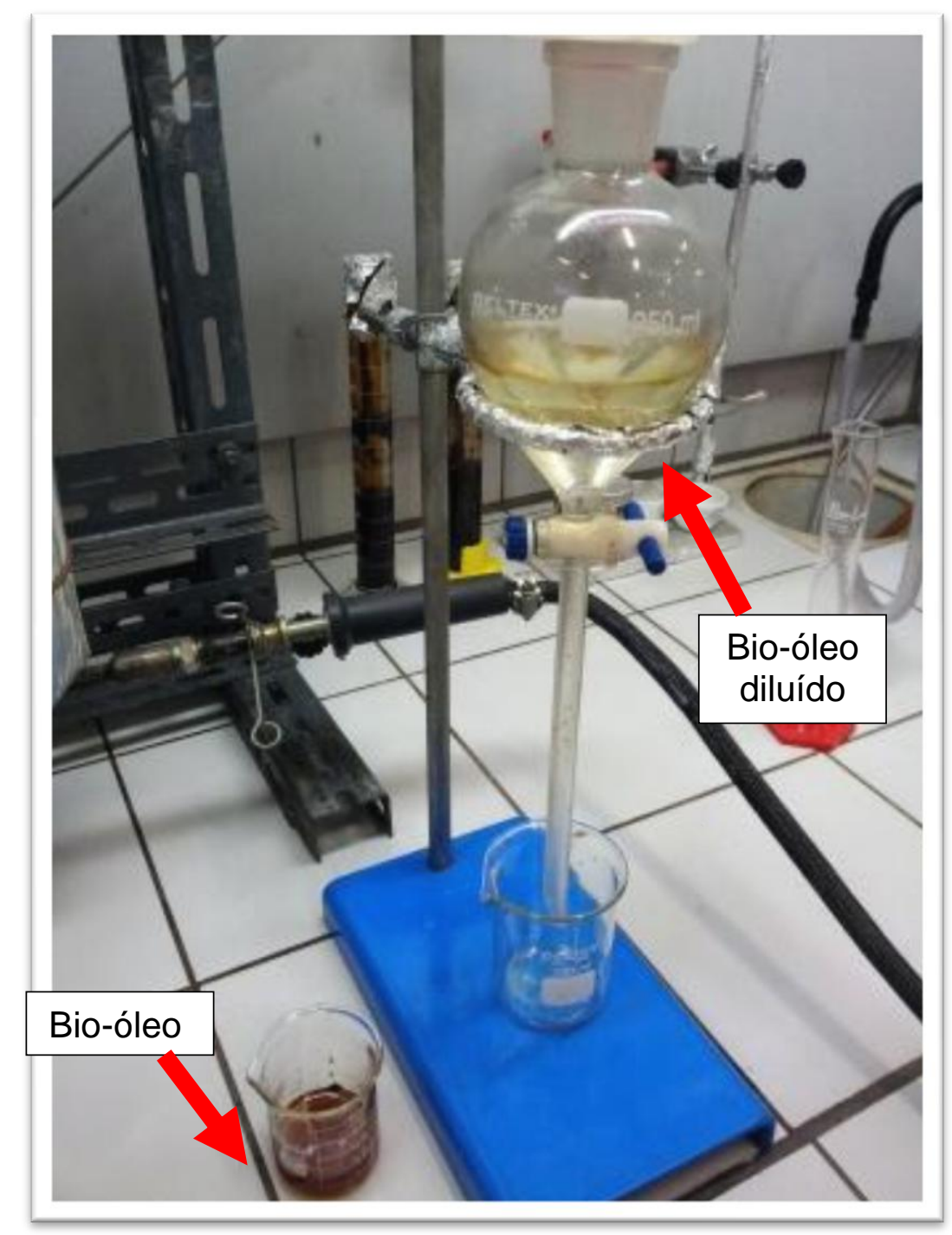

FIGURA 37 - Extração da fração orgânica do bio-óleo com diclorometano para preparação da análise de GC/MS. 


\subsubsection{Bio-óleo esterificado}

Para a esterificação do bio-óleo foram medidos $50 \mathrm{~mL}$ do bio-óleo, o mesmo volume de etanol, e $3 \mathrm{~mL}$ de ácido clorídrico (HCl) 10\% (FIG.38), ficando essa mistura em refluxo a temperatura branda por 2 horas. Após essa etapa, a fração orgânica foi analisada por GC/MS.

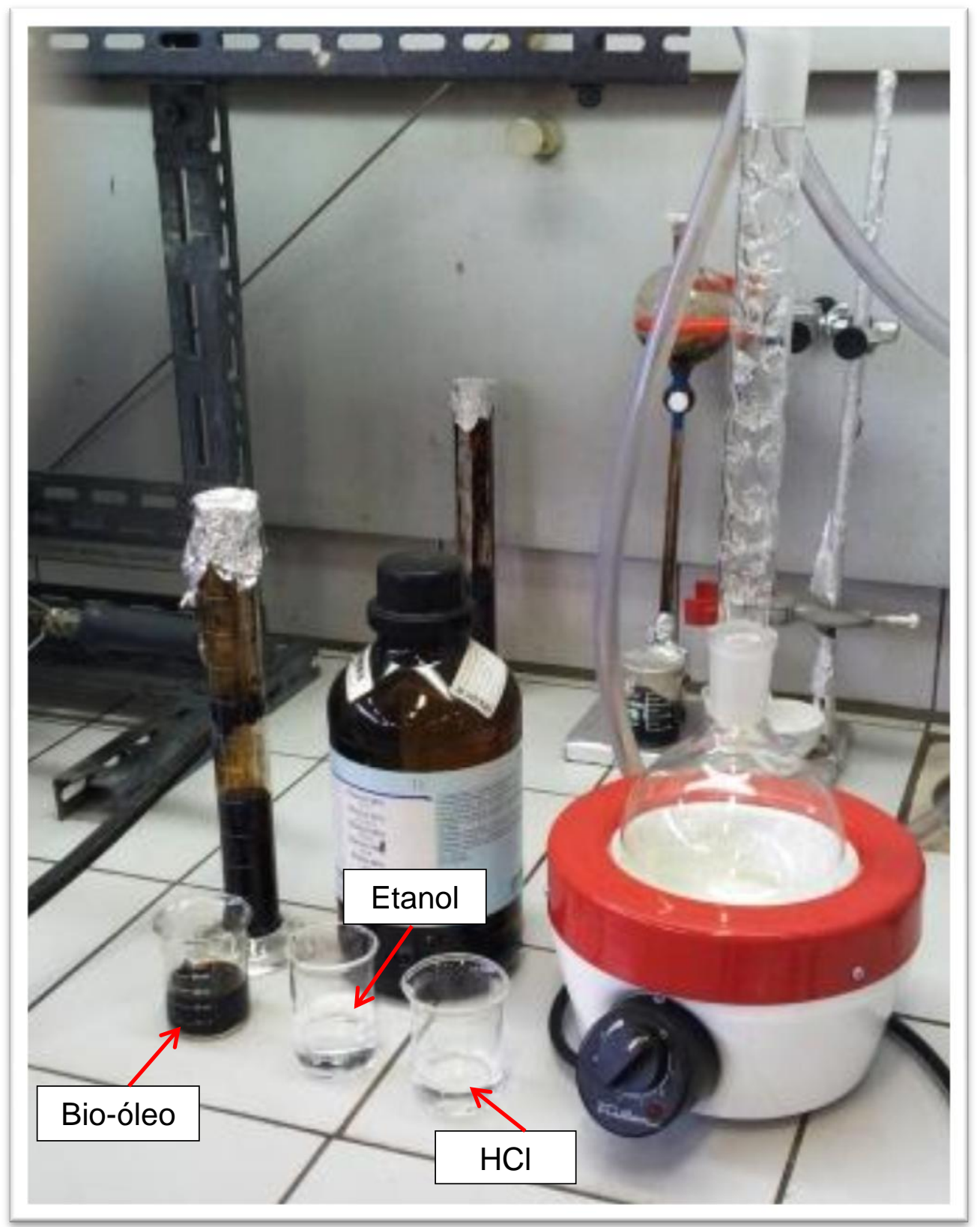

FIGURA 38 - Sistema de refluxo e reagentes utilizados para a esterificação do bio-óleo. 


\subsubsection{Análise do hidrogênio por cromatografia a gás}

As análises por cromatografia à gás foram realizadas em tempo real, coletando-se $10 \mu \mathrm{L}$ do gás produzido pelo processo de pirólise e injetando em Cromatógrafo, marca Agilent Technologies, modelo 7890 (FIG.39).

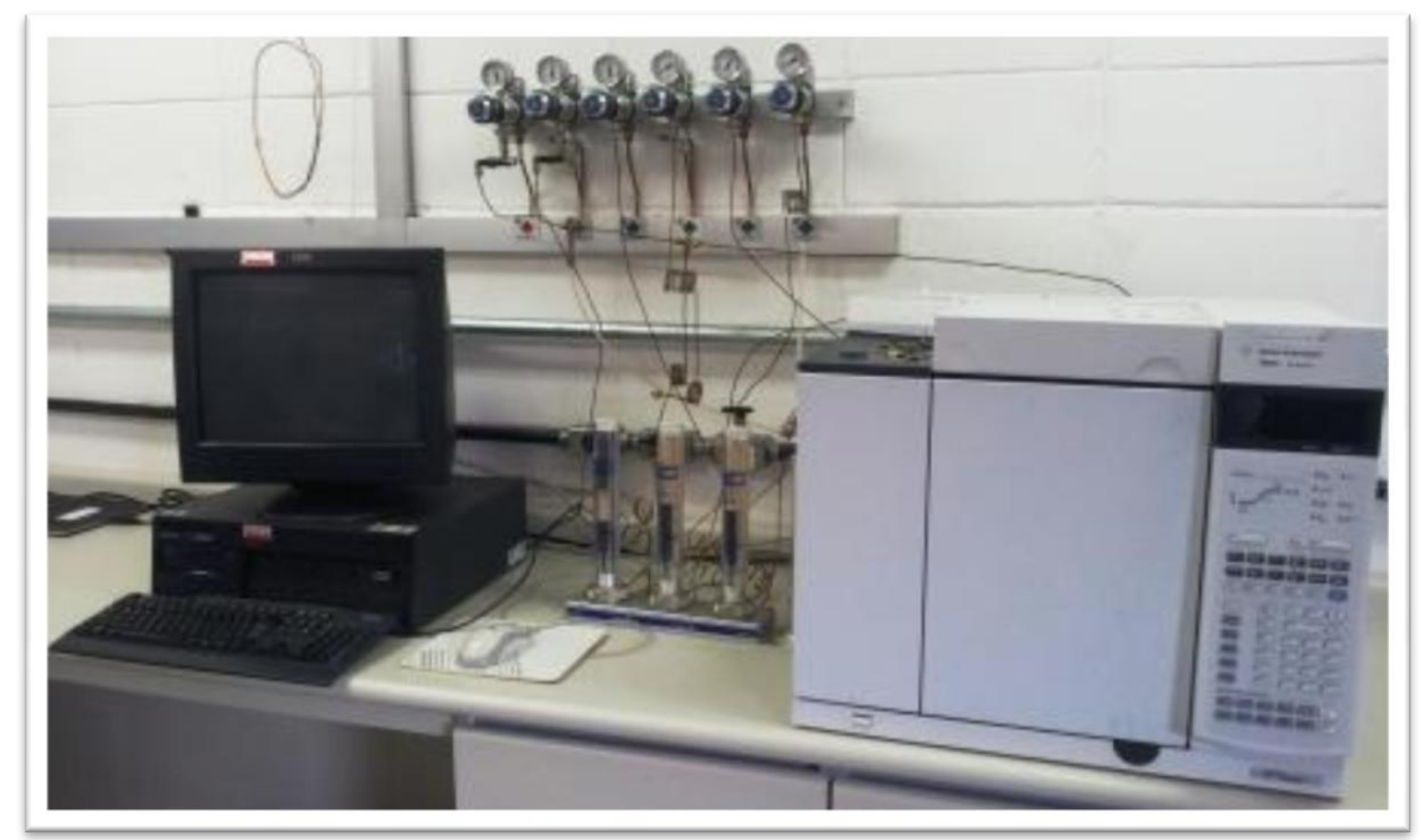

FIGURA 39 - Ilustração do cromatógrafo utilizado nas análises dos gases.

Na FIG.40 apresenta-se o procedimento de retirada de amostra dos gases do processo de pirólise para análise, em tempo real, em cromatógrafo a gás. 


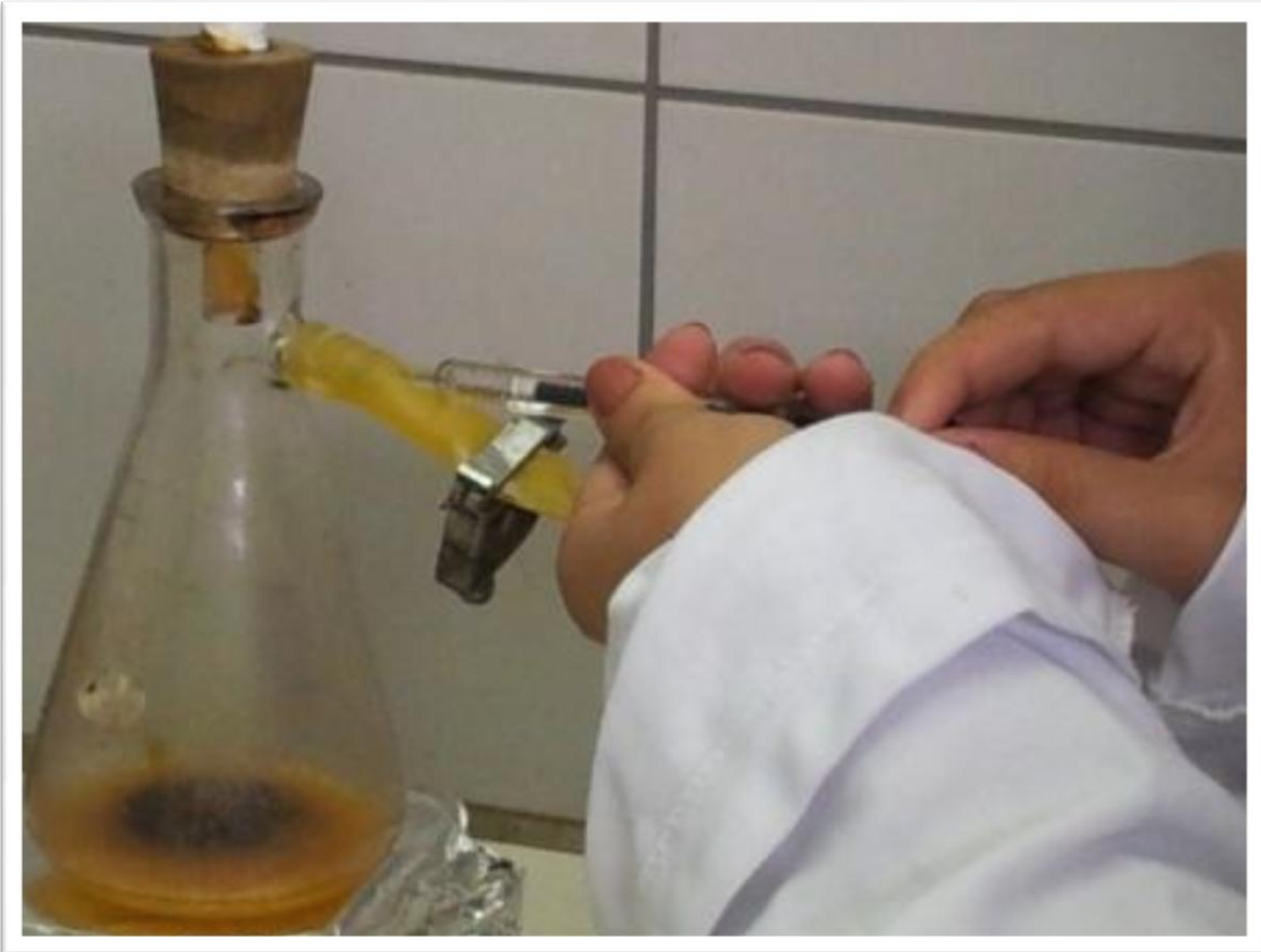

FIGURA 40 - Ilustração do procedimento de retirada de amostra dos gases do processo de pirólise para análise, em tempo real, em cromatógrafo a gás. 


\section{$5 \quad$ RESULTADOS E DISCUSSÕES}

\subsection{Caracterização da biomassa}

A biomassa foi caracterizada por meio das análises imediata, elementar, térmica e cromatografia a gás acoplada a espectômetro de massa.

\subsubsection{Análise imediata}

$\mathrm{Na}$ TAB.7 apresentam-se os resultados da média do teor de umidade, cinzas, voláteis e carbono fixo das amostras da palha do café.

TABELA 7 - Teores de umidade, voláteis, cinzas e carbono fixo da análise imediata da palha do café

$$
\text { Componentes }
$$

Umidade

Voláteis

78,4

Cinzas

6,6
(\%)

8,86 
O teor de cinzas da análise imediata está relacionado com a presença de quantidades e de qualidades diferentes de minerais presentes na biomassa tais como: cálcio, potássio, fósforo, magnésio, ferro e sódio, entre outros.

Para o caso da palha do café, o teor de cinzas contém teores de potássio e fósforo provenientes da adubação, bem como de cálcio, utilizado como corretivo na agricultura cafeeira.

O teor de carbono fixo e de voláteis da análise imediata estão diretamente ligados ao poder calorífico superior (PCS). Vale lembrar, que o cálculo do poder calorífico, deve ser sempre com o material em "base seca", ou seja, a amostra deve estar isenta de umidade.

Para a palha do café foram encontrados os seguintes valores:

$$
\begin{aligned}
& \mathrm{PCS}_{(\mathrm{mv})}=5656,19 \mathrm{kcal} / \mathrm{kg} \longrightarrow 23,64 \mathrm{MJ} / \mathrm{kg} \quad \text { onde } \mathrm{mv}=\text { material volátil } \\
& \mathrm{PCS}_{(\mathrm{cf})}=5433,48 \mathrm{kcal} / \mathrm{kg} \longrightarrow 22,70 \mathrm{MJ} / \mathrm{kg} \quad \text { onde } \mathrm{cf}=\text { carbono fixo }
\end{aligned}
$$

$\mathrm{Na}$ TAB.8, podem-se observar os valores do poder calorífico superior de diferentes biomassas, podendo-se inferir que a palha do café tem maior poder calorífico quando comparada a outros resíduos, podendo ser considerada como um bom combustível. 
TABELA 8 - Dados do poder calorífico superior de diferentes biomassas (base seca)

\begin{tabular}{cc}
\hline Tipo de Biomassa & Poder calorífico superior \\
\cline { 2 - 2 } PCS) & $(\mathbf{M J} / \mathbf{k g})$ \\
\cline { 2 - 2 } Pínus & 20,02 \\
Eucalipto & 19,42 \\
\hline Casca de arroz & 16,14 \\
\hline Bagaço de cana & 17,33 \\
\hline Casca de coco & 19,04 \\
\hline Sabugo de milho & 18,77 \\
\hline Ramos de algodão & 18,26 \\
\hline Resíduos sólidos urbanos & 19,87 \\
\hline Excrementos de gado & 17,36 \\
\hline
\end{tabular}

Fonte: Cortez, L. A. B. et al. (org.), 2009, p. 51

\subsubsection{Análise elementar}

A TAB.9 apresenta os resultados da média do teor de carbono (C), hidrogênio $(H)$ e nitrogênio $(N)$, das amostras da palha do café. A porcentagem de oxigênio $(\mathrm{O})$ foi calculado pela diferença da soma dos outros elementos, ou seja:

$$
\mathrm{O}=100 \%-(\mathrm{C}+\mathrm{H}+\mathrm{N}) \%
$$


TABELA 9 - Dados obtidos da análise elementar da palha do café

\begin{tabular}{cc}
\hline Elemento & $\%$ Base seca \\
\hline $\mathrm{C}$ & $35,5 \pm 0,8$ \\
$\mathrm{H}$ & $5,5 \pm 0,1$ \\
$\mathrm{~N}$ & $1,25 \pm 0,09$ \\
$\mathrm{O}$ & $57,8 \pm 0,7$ \\
\hline
\end{tabular}

Sendo a palha do café um material essencialmente orgânico, era de se esperar um alto valor de carbono em sua constituição, porém o hidrogênio, objeto deste estudo também apresenta um percentual atrativo se comparado a outras biomassas, viabilizando assim o processo de pirólise proposto (TAB.10).

TABELA 10 - Composição elementar de diferentes biomassas (base seca)

\begin{tabular}{ccccc}
\hline & \multicolumn{3}{c}{ Composição Elementar (\%) } \\
\cline { 2 - 5 } Tipo de Biomassa & $\mathbf{C}$ & $\mathbf{H}$ & $\mathbf{O}$ & $\mathbf{N}$ \\
\cline { 2 - 5 } Pínus & 49,25 & 5,99 & 44,36 & 0,06 \\
Eucalipto & 49,00 & 5,87 & 43,97 & 0,30 \\
Casca de arroz & 40,96 & 4,30 & 35,86 & 0,40 \\
Bagaço de cana & 44,80 & 5,35 & 39,55 & 0,38 \\
Casca de coco & 48,23 & 5,23 & 33,19 & 2,98 \\
\hline Sabugo de milho & 46,58 & 5,87 & 45,46 & 0,47 \\
\hline Ramas de Algodão & 47,05 & 5,35 & 40,77 & 0,65 \\
\hline
\end{tabular}




\subsubsection{Termogravimetria/Termogravimetria Derivada (TG/DTG) e Calorimetria Exploratória Diferencial (DSC)}

Foram realizadas as medidas de TG/DTG e DSC das palhas interna, externa e da mistura de ambas as palhas.

\subsubsection{Palha Interna}

As curvas TG/DTG da amostra da palha interna de café (FIG.41) evidenciaram uma decomposição térmica em cinco etapas de perdas de massa consecutivas, sendo que a terceira e a quarta são concomitantes.

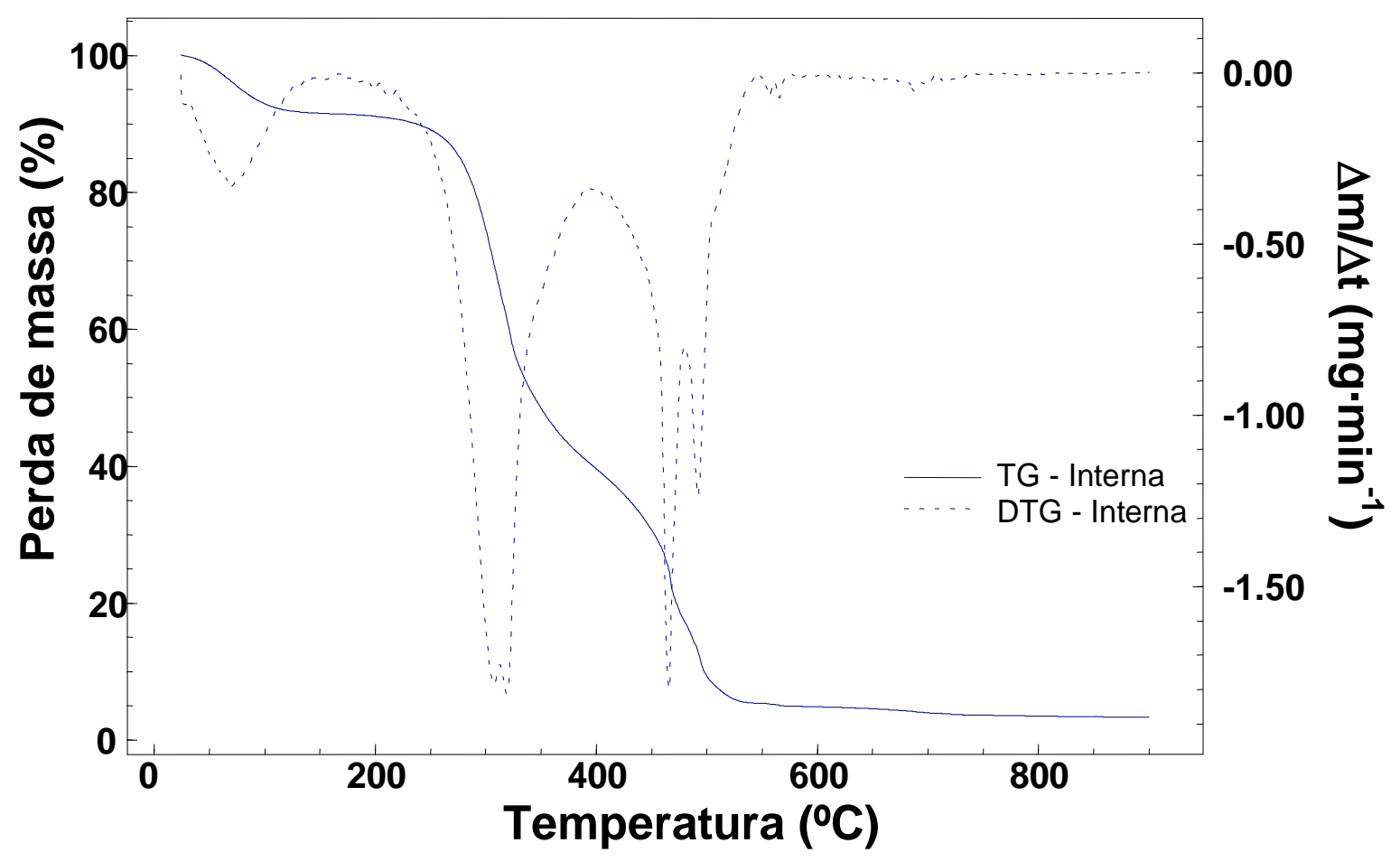

FIGURA 41 - Curvas TG/DTG da amostra da palha interna do café.

O primeiro evento de perda de massa (até $150{ }^{\circ} \mathrm{C}$ ) pode ser relacionado com a desidratação do material em estudo, ao qual se associa uma variação de $8,6 \%$ de massa. A segunda e terceira perdas de massa estão relacionadas à decomposição térmica do material em estudo, com uma variação 
total de $86,2 \%$. O terceiro evento acontece em duas etapas consecutivas e concomitantes, pois antes do término da terceira decomposição térmica inicia-se o quarto evento de perda de massa. A palha interna decompõe-se quase totalmente, resultando em uma massa residual de 3,2\% da massa original.

Observa-se o aumento da porcentagem de perda de massa no evento que se supõe ser a decomposição térmica da matéria orgânica (segundo, terceiro e quarto eventos). Em contrapartida é observado uma diminuição na massa residual, a qual foi associada à existência de material inorgânico, devido ao valor da temperatura final $\left(900^{\circ} \mathrm{C}\right)$. Pode ser que a presença de uma maior quantidade de material inorgânico na parte externa possibilite que este material resista mais à tração, característica apresentada pela sua dureza.

Na FIG.42 tem-se a curva DSC da amostra da palha interna do café.

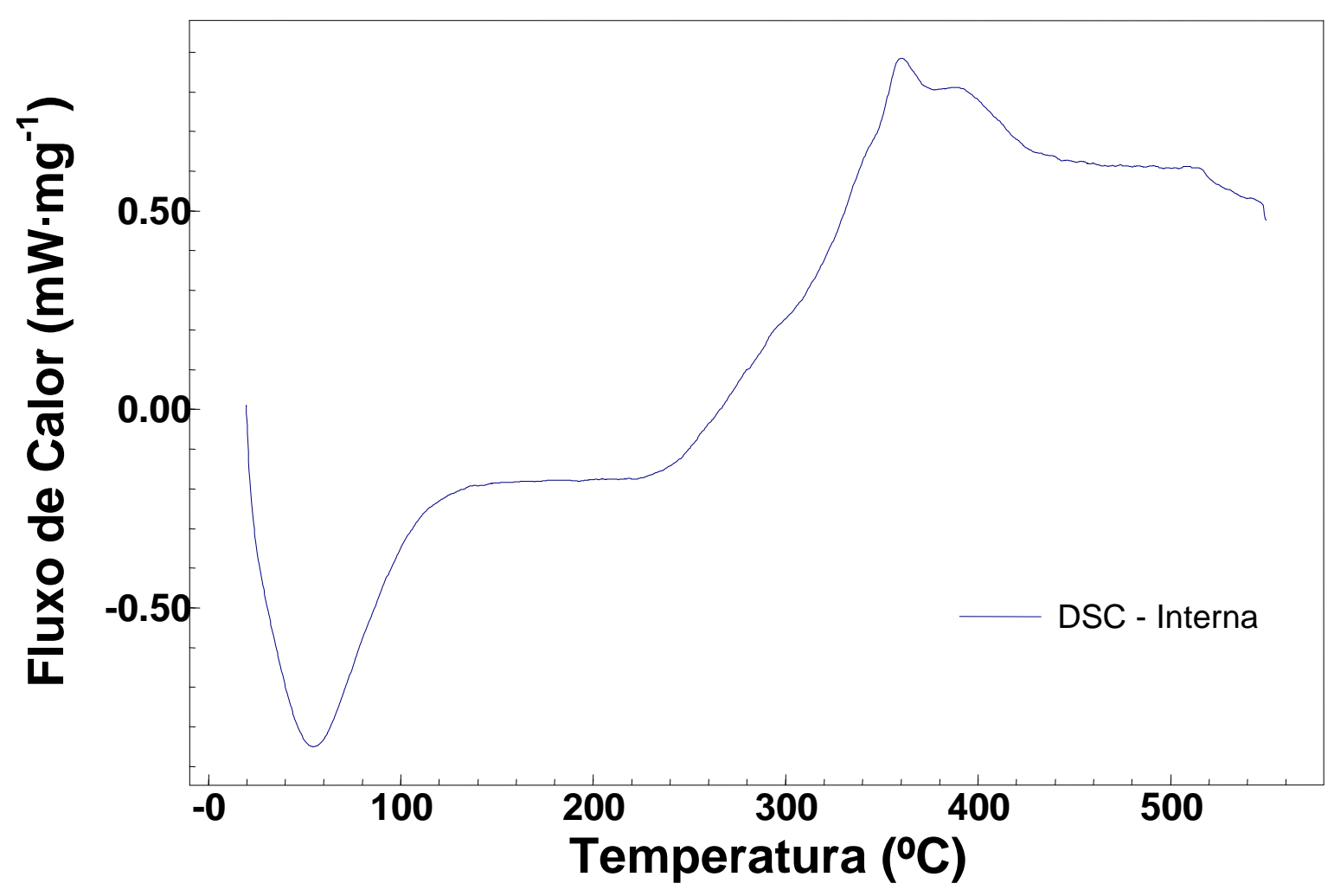

FIGURA 42 - Curva DSC da amostra da palha interna do café.

A curva DSC evidencia um evento endotérmico no início seguido de eventos exotérmicos consecutivos e concomitantes. Este evento corrobora os 
dados obtidos das curvas TG/DTG para o primeiro evento de decomposição térmica confirmando uma possível desidratação.

\subsubsection{Palha Externa}

A análise das curvas TG/DTG (FIG.43) permitiu inferir que a decomposição térmica da amostra da palha externa de café ocorre em quatro etapas consecutivas.

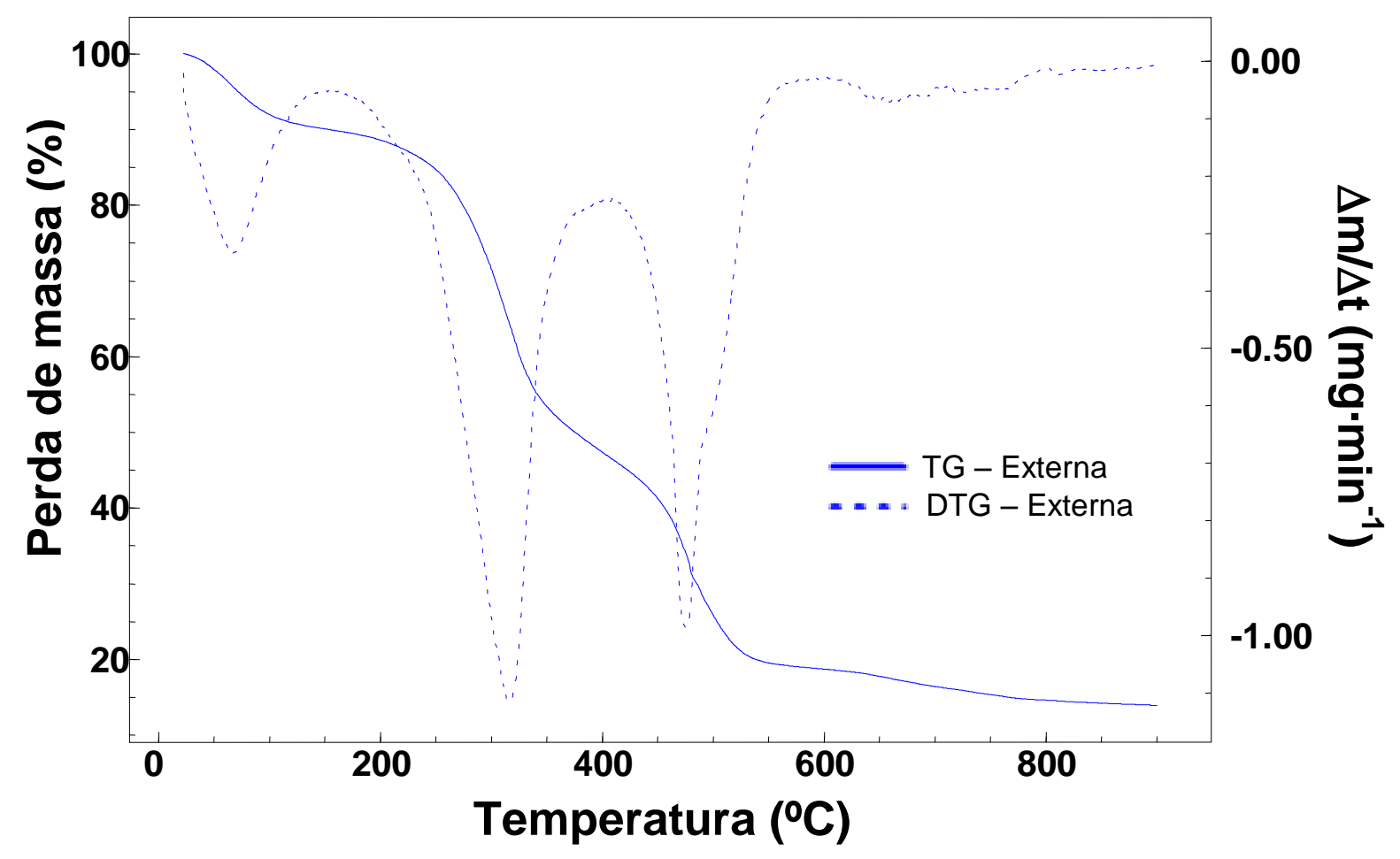

FIGURA 43 - Curvas TG/DTG da amostra da palha externa do café.

O primeiro evento de decomposição térmica (até $150^{\circ} \mathrm{C}$ ) está relacionado com a liberação de água, ou seja, desidratação, ao qual se associa $10 \%$ de perda de massa. Os eventos seguintes estão relacionados com a decomposição térmica do material. O segundo e terceiro eventos se relacionam com a decomposição térmica da matéria orgânica presente, totalizando $71 \%$ de perda de massa. Contudo, pode-se sugerir que o quarto evento observado, que se inicia em $580 \stackrel{\circ}{\circ}$ esteja relacionado com a decomposição térmica de algum composto inorgânico presente. Esta hipótese se fundamenta no fato de que acima 
de $500{ }^{\circ} \mathrm{C}$ os compostos orgânicos são instáveis termicamente e também pelo fato da decomposição representar apenas $5 \%$ da massa inicial.

A decomposição térmica desse material não é completa até a temperatura de $900{ }^{\circ} \mathrm{C}$, ou seja, verifica-se a presença de um resíduo de aproximadamente $14 \%$ da massa original. Como essa massa residual não se decompõe até esta temperatura, isso indica a presença de material inorgânico.

$\mathrm{Na}$ FIG.44 temos a curva DSC da amostra da palha interna do café.

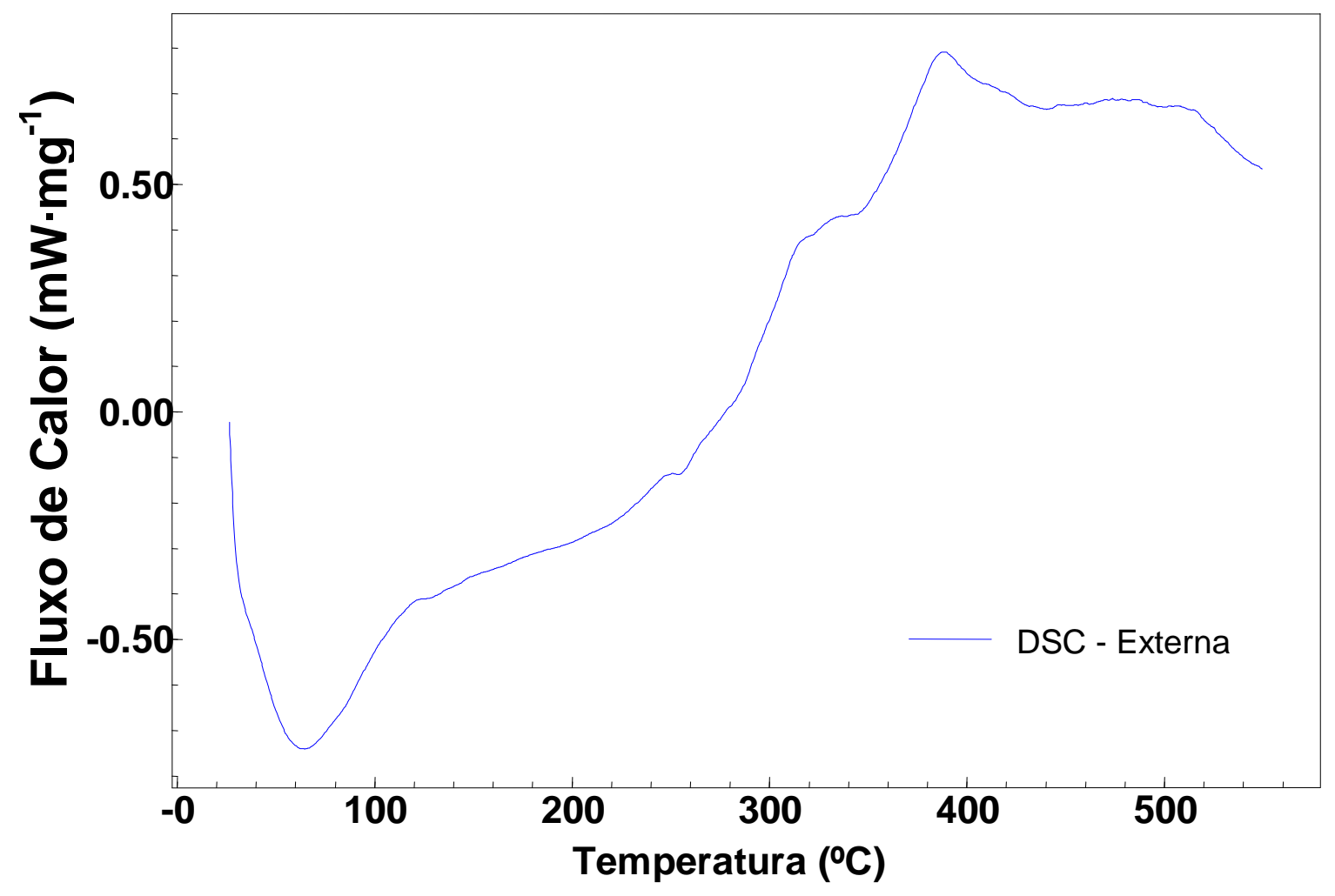

FIGURA 44 - Curva DSC da amostra da palha externa do café.

A curva DSC evidencia um evento endotérmico ao início (até $110 \stackrel{\circ}{\circ}$, aproximadamente), em seguida mostra um evento exotérmico de decomposição térmica. O pico endotérmico associa-se a desidratação corroborando os dados de termogravimetria. A decomposição térmica do material acontece, em termos energéticos, de forma exotérmica em eventos consecutivos e concomitantes.

$\mathrm{Na}$ TAB.11 tem-se as perdas de massa nos respectivos intervalos de temperatura. 
TABELA 11 - Perda de massa (\%) em relação à temperatura de decomposição (\%) de cada evento térmico das palhas interna e externa do café

\begin{tabular}{c|c|c}
\hline \multirow{2}{*}{$\begin{array}{c}{\left[\mathbf{T}_{\mathrm{i}}-\mathrm{T}_{\mathrm{f}}\right]} \\
\left({ }^{0} \mathrm{C}\right)\end{array}$} & \multicolumn{2}{|c}{$\Delta \mathrm{m}(\%)$} \\
\cline { 2 - 3 } & Interna & Externa \\
\hline $25-150$ & 8,55 & 10,04 \\
$151-400$ & 51,2 & 43,19 \\
$401-580$ & 34,95 & 27,83 \\
$581-900$ & 2,08 & 5,08 \\
$25-900$ & 96,77 & 86,13 \\
Resíduo & 3,23 & 13,87 \\
\hline
\end{tabular}

$\mathrm{Na}$ TAB.12 tem-se os dados da variação de entalpia, temperatura inicial, a temperatura de pico e onset relacionadas com a desidratação do material em estudo. Estes dados foram obtidos a partir das curvas de TG / DTG e DSC das amostras das palhas interna e externa do café.

TABELA 12 - Variação de entalpia, temperaturas onset e de pico para as amostras das palhas interna e externa do café

\begin{tabular}{cccc}
\hline Amostra & $\mathbf{T}_{\text {onset }}\left({ }^{0} \mathbf{C}\right)$ & $\mathbf{T}_{\text {pico }}\left({ }^{0} \mathbf{C}\right)$ & $\Delta \mathbf{H}\left(\mathbf{J ~ g ~}^{-1}\right)$ \\
\hline Interna & 20 & 54,3 & 217,5 \\
Externa & 27 & 64,5 & 223,4 \\
\hline
\end{tabular}


Os dados de TG/DTG e DSC das palhas interna e externa do café foram importantes na determinação do comportamento térmico das amostras como estudo e parâmetros na conversão térmica, inferindo a eficácia na determinação da taxa de decomposição das palhas, quando da avaliação de sua estabilidade térmica. Contudo, o mesmo se pode inferir à mistura das duas palhas, interna e externa, que mostrou ser mais viável na utilização conjunta, uma vez que a entalpia de decomposição da mistura tem um valor maior.

\subsubsection{Mistura das palhas interna e externa}

As curvas TG/DTG (FIG.45) da mistura das palhas interna e externa do café evidenciam sucessivos eventos de perda de massa, dos quais alguns são consecutivos enquanto outros são concomitantes. A primeira perda de massa observada está relacionada com a liberação de água presente na amostra. Esta associação pode ser corroborada pela curva de DSC, a qual apresenta um evento endotérmico na mesma faixa de temperatura.

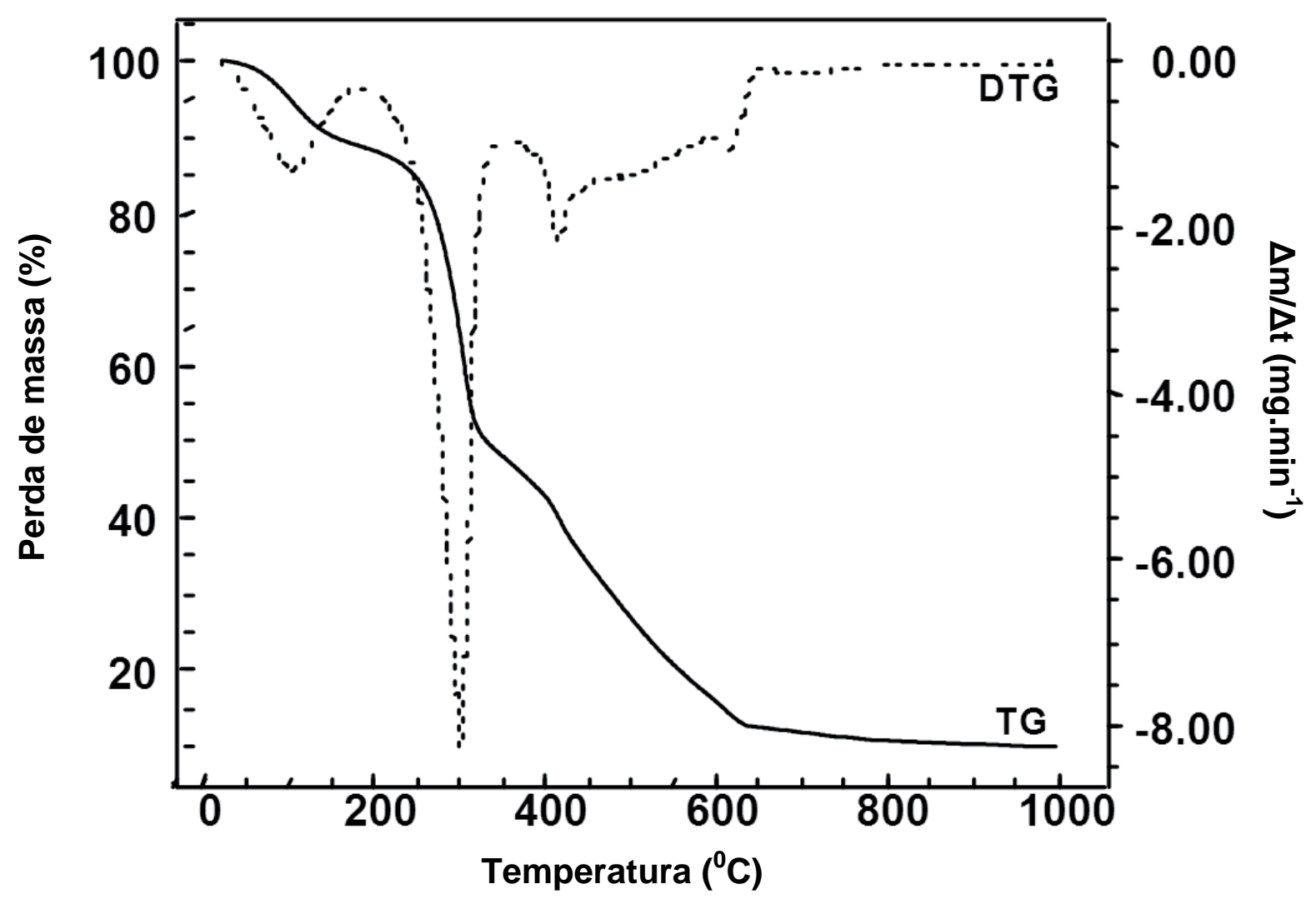

FIGURA 45 - Curvas TG/DTG da amostra da mistura da palha do café. 


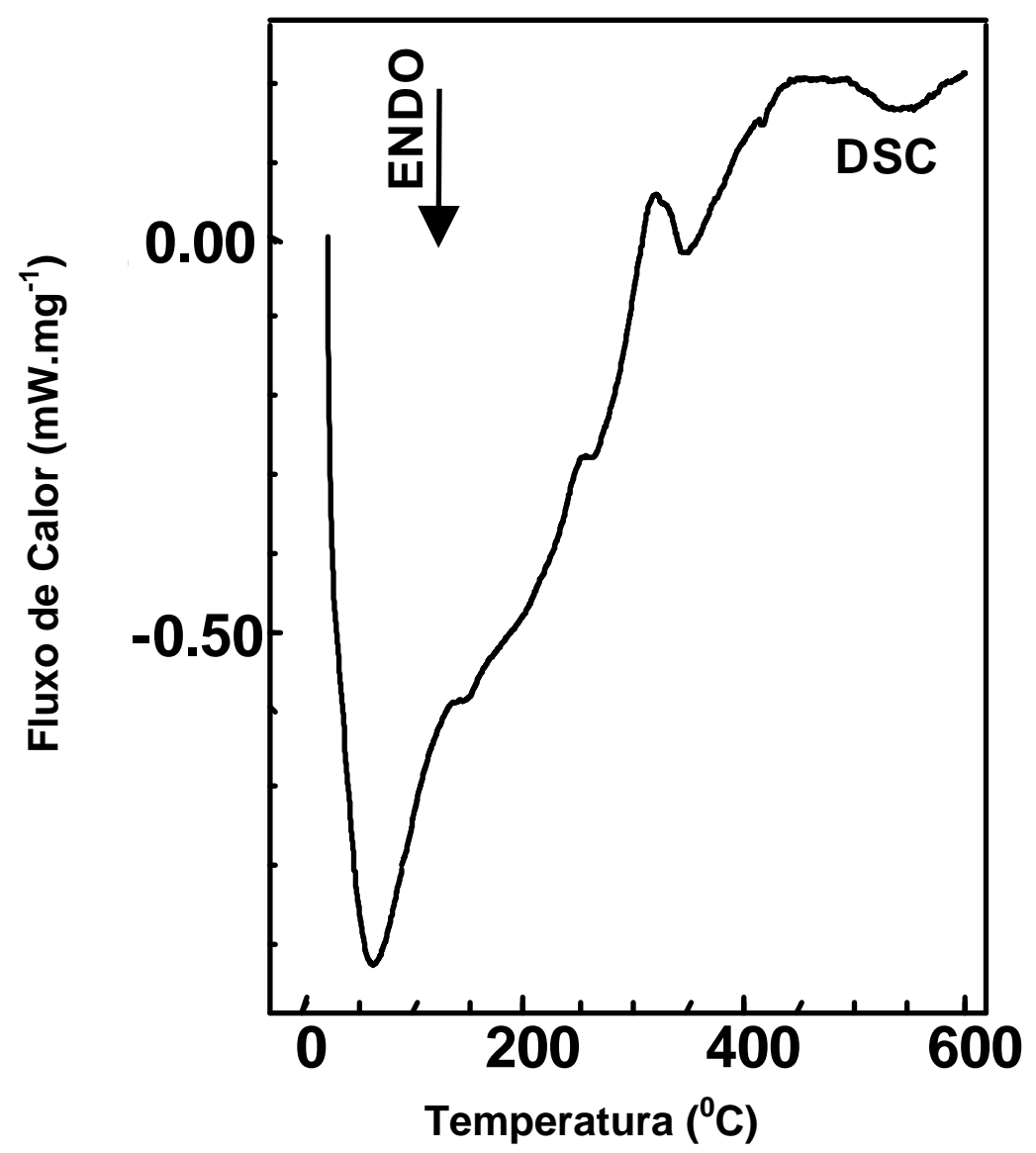

FIGURA 46 - Curva DSC da amostra da mistura da palha do café.

A partir da curva DSC (FIG.46) da amostra fez-se uma estimativa da variação de entalpia encontrada no processo de decomposição térmica da mesma. Afirma-se ser uma estimativa pelo fato de que a mesma tem seu processo de decomposição térmica até uma temperatura superior aos $600^{\circ} \mathrm{C}$ observados pela técnica de calorimetria utilizada. $O$ valor experimental obtido foi de $\quad 249,0 \mathrm{~J} \mathrm{~g}^{-1}$, com $\mathrm{T}_{\text {onset }}=280,7^{\circ} \mathrm{C}$. A temperatura onset indicada pode ser relacionada com o início da decomposição térmica do material orgânico presente, ou seja, com o início da carbonização da amostra. Nas curvas TG/DTG este evento é evidenciado na segunda perda de massa, correspondente a $40,5 \%$ da massa inicial.

Na TAB.13 pode-se observar a variação percentual da perda de massa em função da decomposição térmica da palha do café, observando-se a 
continuidade do evento após os $900^{\circ} \mathrm{C}$, sugerindo a presença de material inorgânico.

TABELA 13 - Perda de massa (\%) em relação à temperatura de decomposição (\%) de cada evento térmico da palha do café

\begin{tabular}{cc}
{$\left[\begin{array}{c}\left.\mathrm{T}_{\mathrm{i}}-\mathrm{T}_{\mathrm{f}}\right] \\
\left({ }^{0} \mathrm{C}\right)\end{array}\right.$} & $\Delta \mathrm{m}(\%)$ \\
\hline $25-150$ & 11,18 \\
$151-400$ & 44,15 \\
$401-580$ & 32,35 \\
$581-900$ & 2,46 \\
$25-900$ & 90,15 \\
\hline
\end{tabular}

A TAB.14 apresenta os valores obtidos a partir da curva DSC da amostra da palha do café. O valor da entalpia de decomposição térmica é próximo ao real visto que após a temperatura de pico ainda há amostra sendo decomposta. 
TABELA 14 - Dados de entalpia, temperaturas onset e de pico para a amostra da palha do café

\begin{tabular}{|c|c|c|c|c|c|}
\hline \multicolumn{2}{|r|}{ Evento } & \multicolumn{2}{|c|}{$\Delta \mathbf{H}$} & \multirow{2}{*}{$\mathbf{T}_{\text {onset }}\left({ }^{\circ} \mathbf{C}\right)$} & \multirow{2}{*}{$\mathbf{T}_{\text {pico }}\left({ }^{\circ} \mathbf{C}\right)$} \\
\hline Número & Característico & Tipo & Valor $\left(\mathrm{J} \mathrm{g}^{-1}\right)$ & & \\
\hline 10 & Desidratação & Endotérmico & 353,0 & 23,7 & 62,1 \\
\hline $2^{\circ}$ & Decomposição & Exotérmico & 249,0 & 280,7 & 494,2 \\
\hline
\end{tabular}

\subsubsection{Cromatografia a gás acoplado a Espectrometria de massas (GC/MS)}

A palha do café in natura e a palha do café seca foram solubilizadas em diferentes tipos de solvente, para que as moléculas da amostra solúveis na fase orgânica fossem extraídas.

Cada uma destas amostras foi solubilizada com quatro diferentes solventes orgânicos: clorofórmio $\left(\mathrm{CHCl}_{3}\right)$, hexano $\left(\mathrm{C}_{6} \mathrm{H}_{14}\right)$, acetonitrila $\left(\mathrm{CH}_{3} \mathrm{CN}\right)$ e diclorometano $\left(\mathrm{CH}_{2} \mathrm{Cl}_{2}\right)$, para que se pudesse avaliar qual ou quais desses solventes seria mais adequado para extrair melhor os ativos que fazem parte da composição química desses materiais.

Depois de cerca de 30 minutos, tempo necessário para que houvesse a extração, observou-se que apenas o solvente clorofórmio não poderia ser utilizado no GC-MS, uma vez que não houve a separação prevista entre a fase aquosa e a orgânica (FIG.47). 


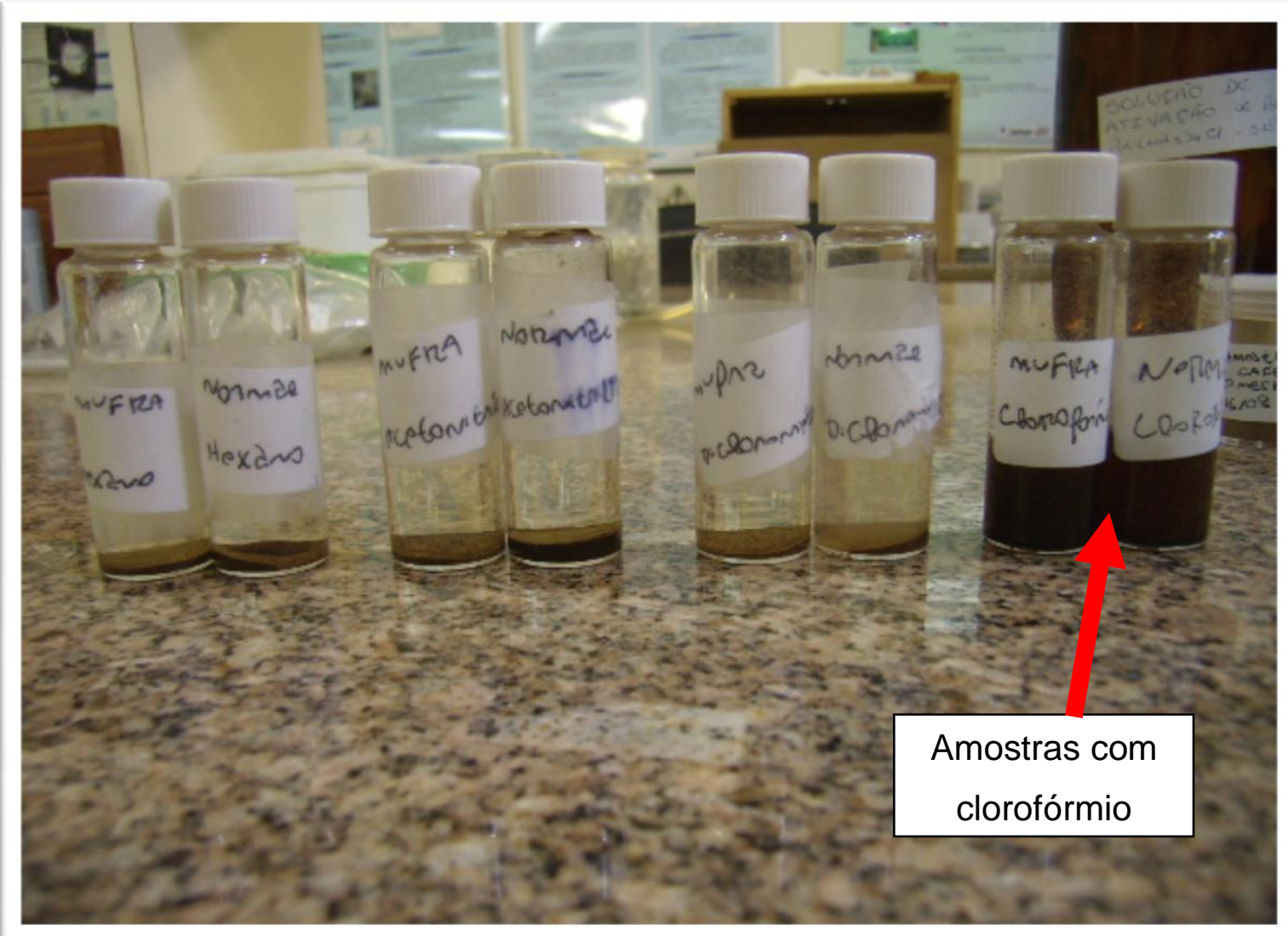

FIGURA 47- Extratos de palha do café obtidos com diferentes tipos de solventes.

Descartadas as amostras em clorofórmio, seis novas amostras foram obtidas, a partir da filtragem e diluição prévia para o procedimento de medidas por GC/MS, como mostrado na FIG.48. 


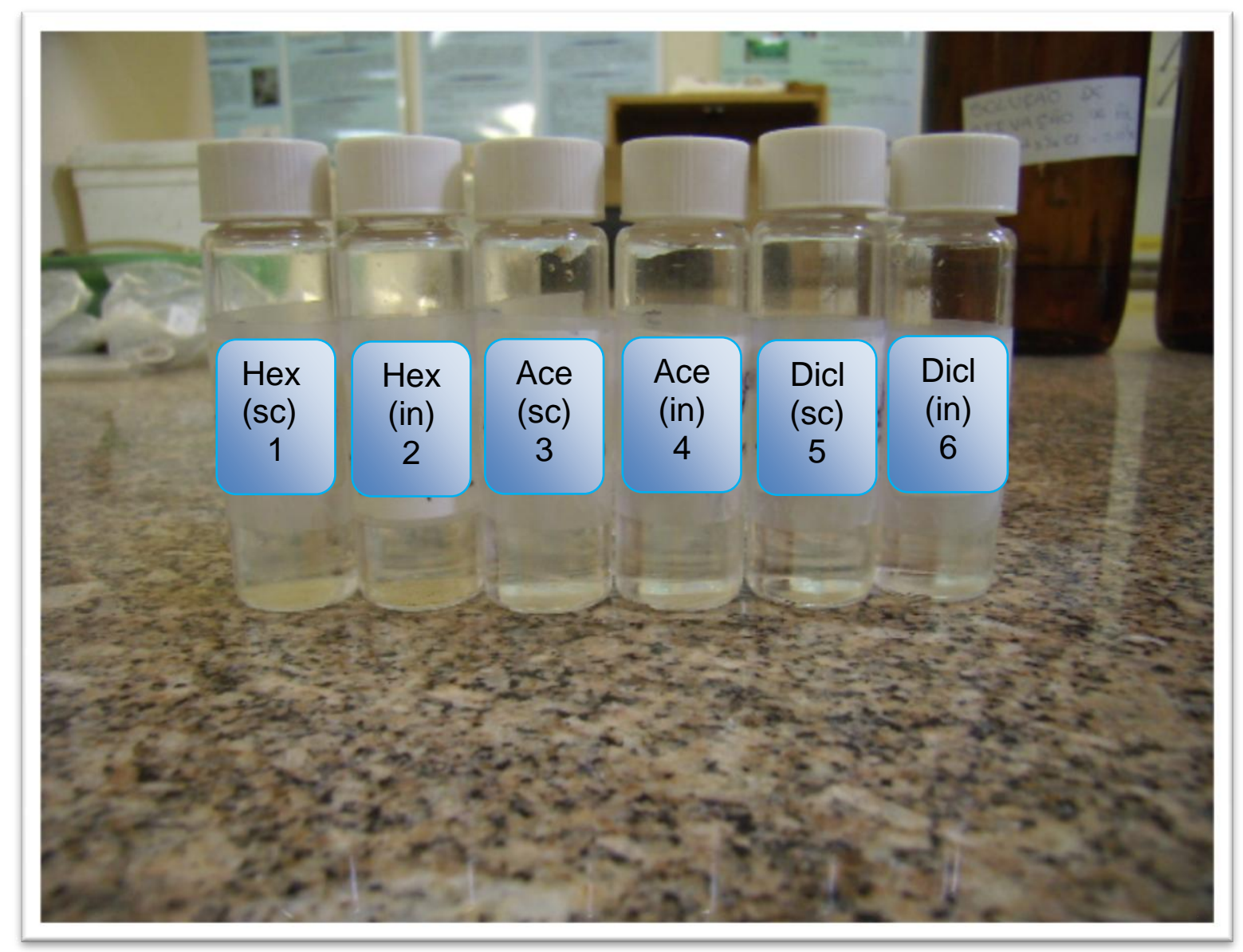

FIGURA 48 - Recipientes contendo os extratos diluídos para utilização nas medidas por GC/MS.

Os resultados das amostras obtidas foram lançados em forma gráfica, onde no eixo $X$ temos o tempo de retenção (min) do íon e no eixo $Y$ temos a contagem de íons presentes na amostra (u.a).

Para cada medida foi obtido um cromatograma, como mostram as FIG.49, $50,51,52,53$ e 54 . 
O resultado da análise por GC/MS da palha do café seca, diluída em hexano está apresentada na FIG.49.

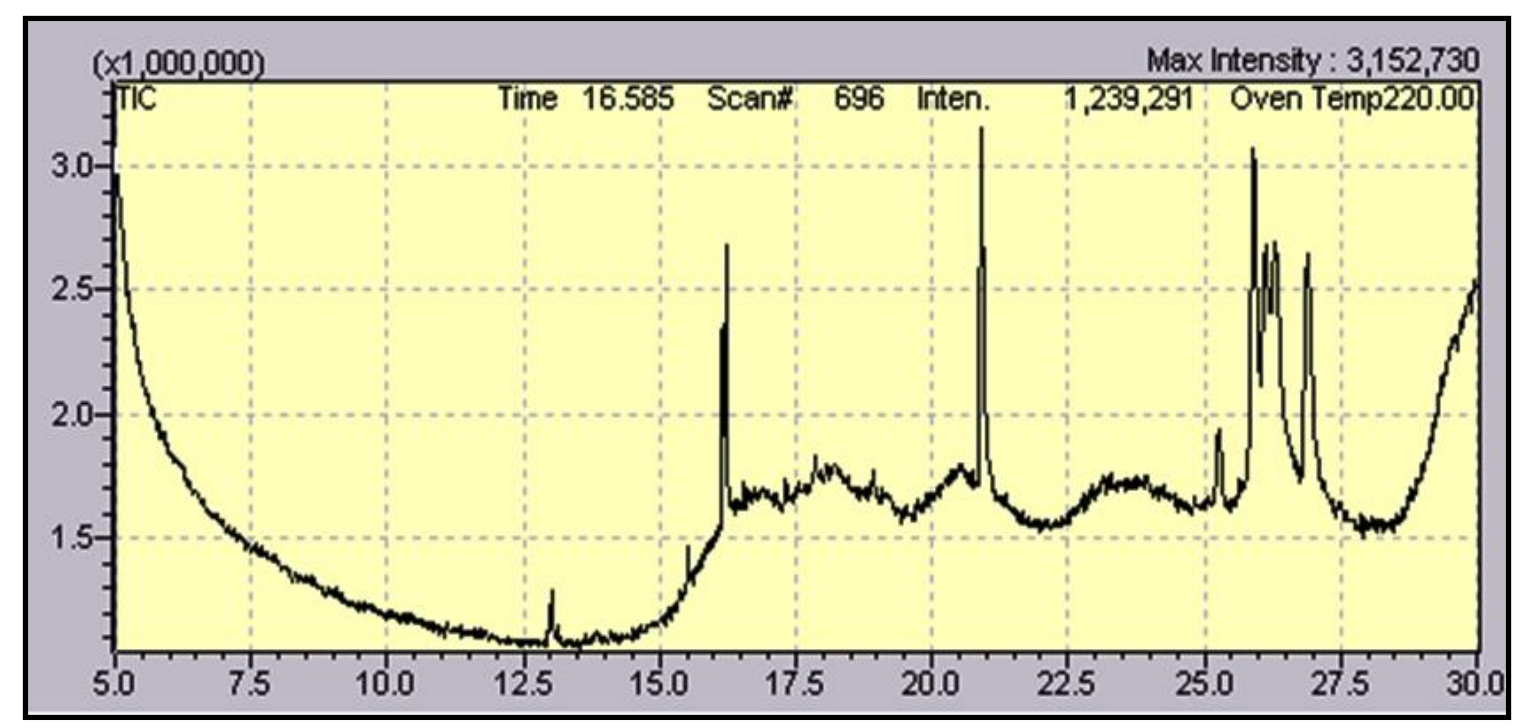

FIGURA 49 - Cromatograma do extrato da amostra da palha do café seca, diluída em hexano, obtido por GC/MS no modo SCAN.

Na FIG.50 apresenta-se o cromatograma do extrato da palha do café in natura diluída em hexano.

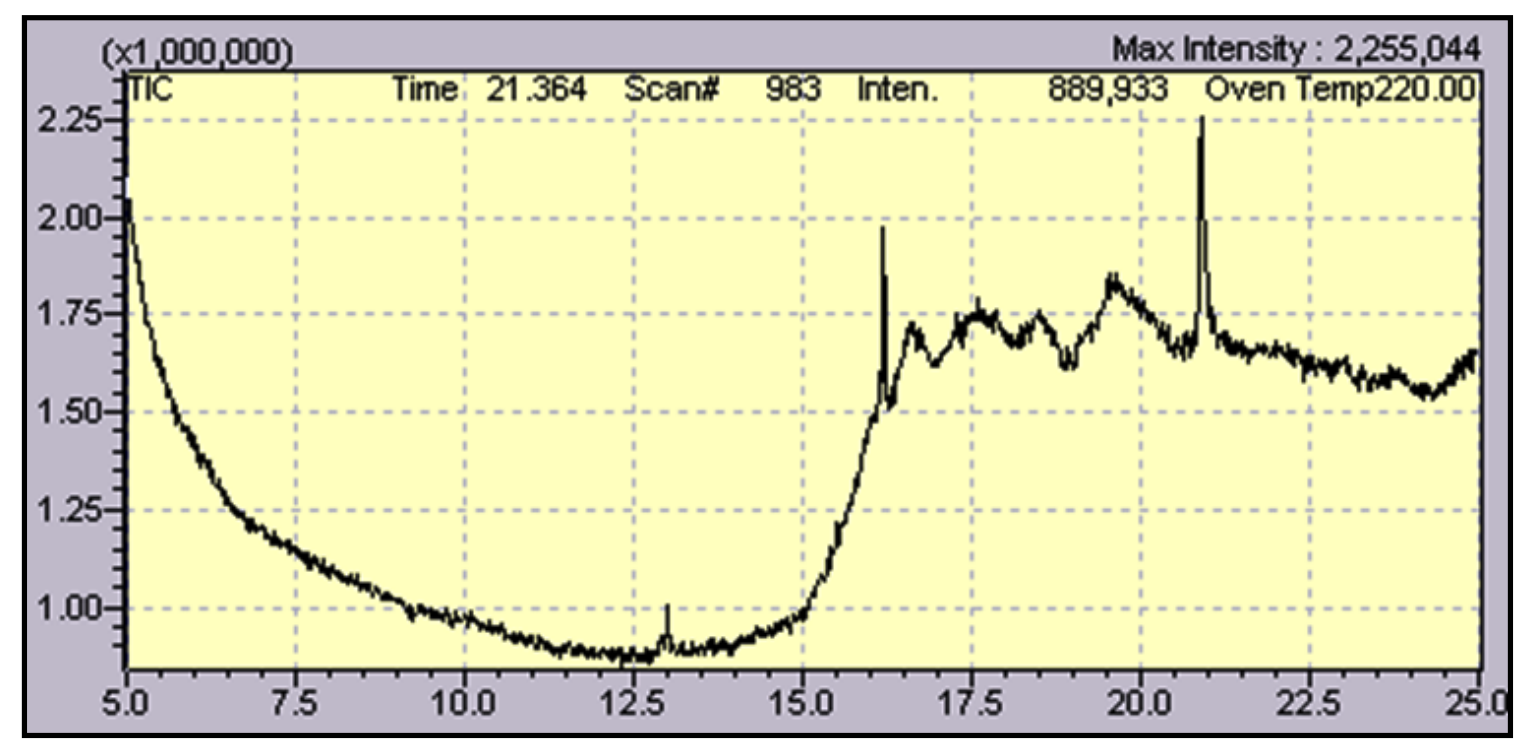

FIGURA 50 - Cromatograma do extrato da amostra da palha do café in natura, diluída em hexano, obtido por GC/MS no modo SCAN. 
Na FIG.51 está representado o o cromatograma do extrato da palha do café seca, diluída no solvente acetonitrila.

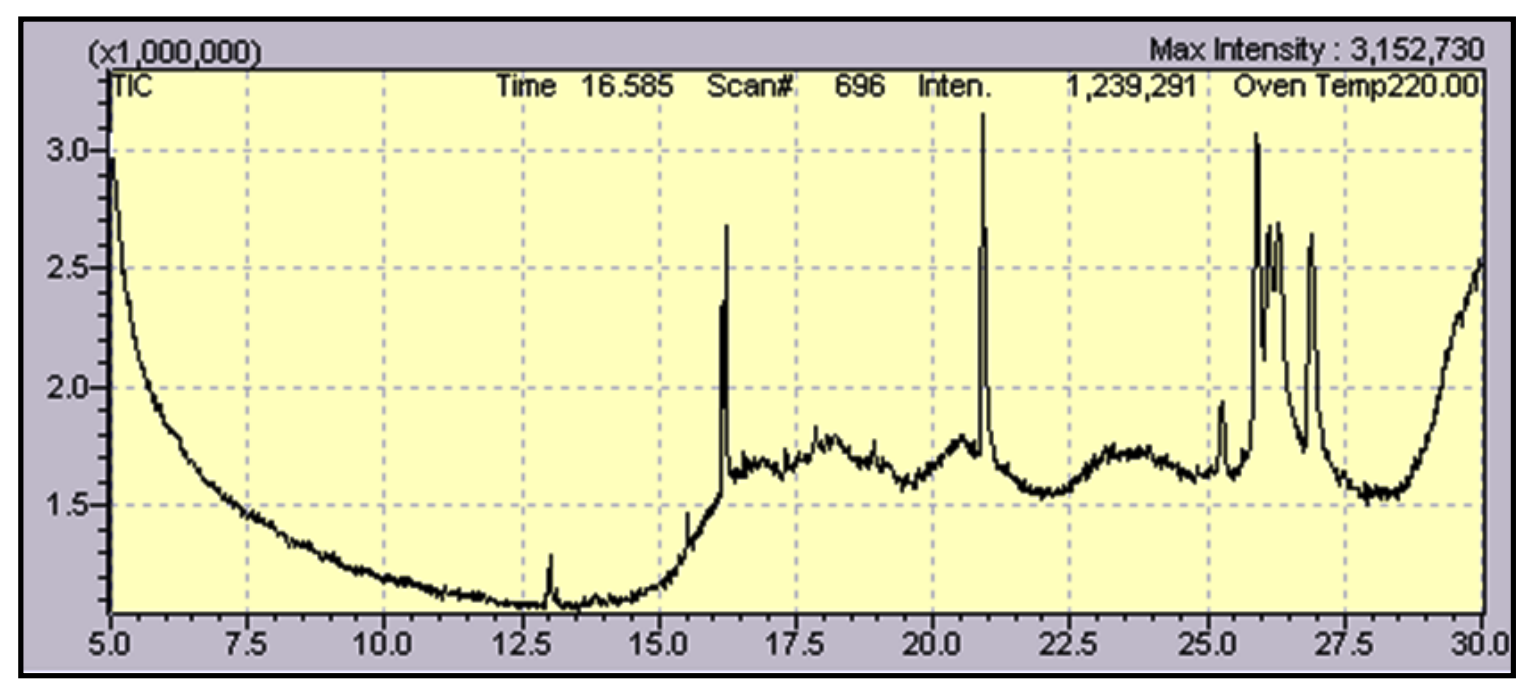

FIGURA 51 - Cromatograma do extrato da palha do café seca, diluída em acetonitrila, obtido por GC/MS no modo SCAN.

Na FIG.52 apresenta-se o cromatograma obtido do extrato da palha do café in natura, diluída no solvente acetonitrila.

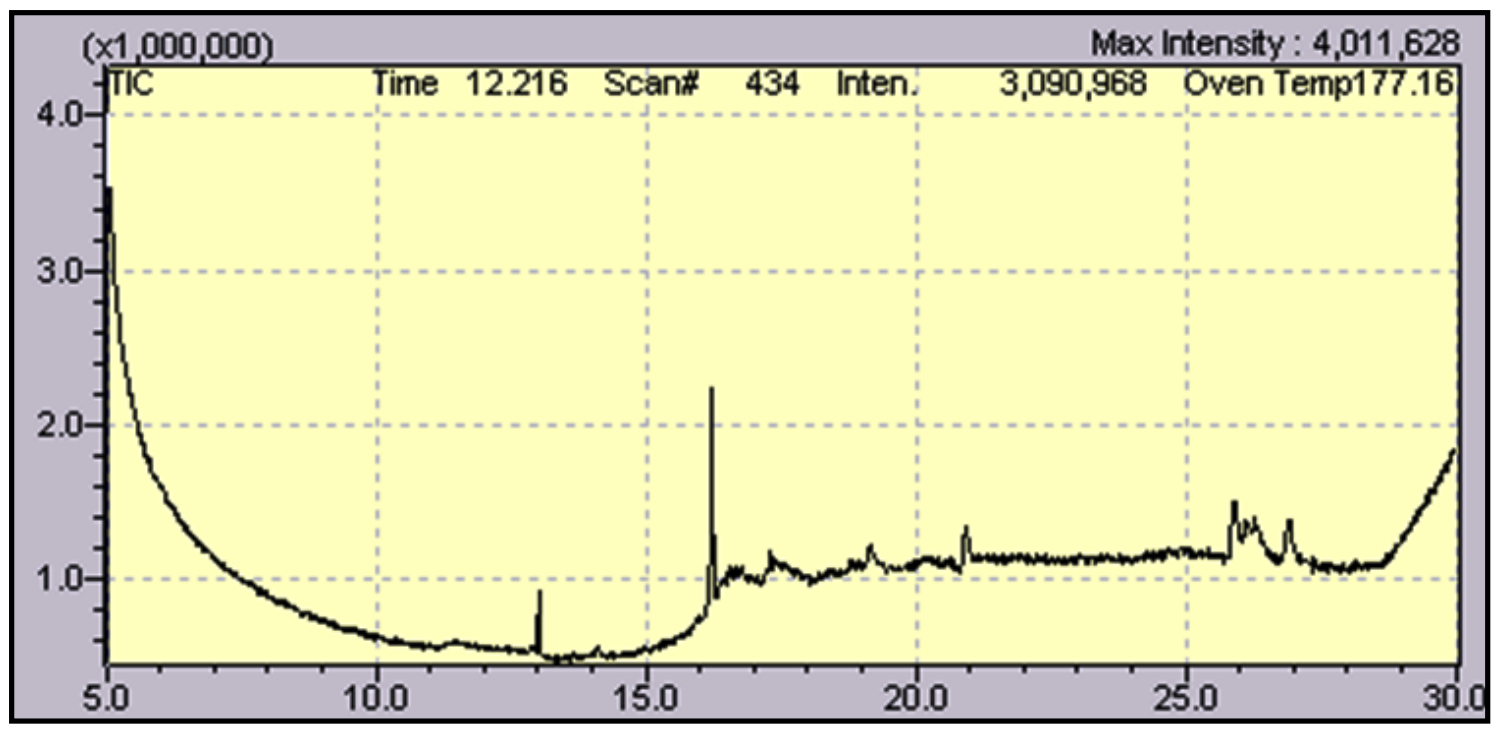

FIGURA 52 - Cromatograma do extrato da palha do café in natura, diluída em acetonitrila, obtido por GC/MS no modo SCAN. 
O cromatograma do extrato obtido da palha do café seca diluída em diclorometano pode ser observada na FIG.53.

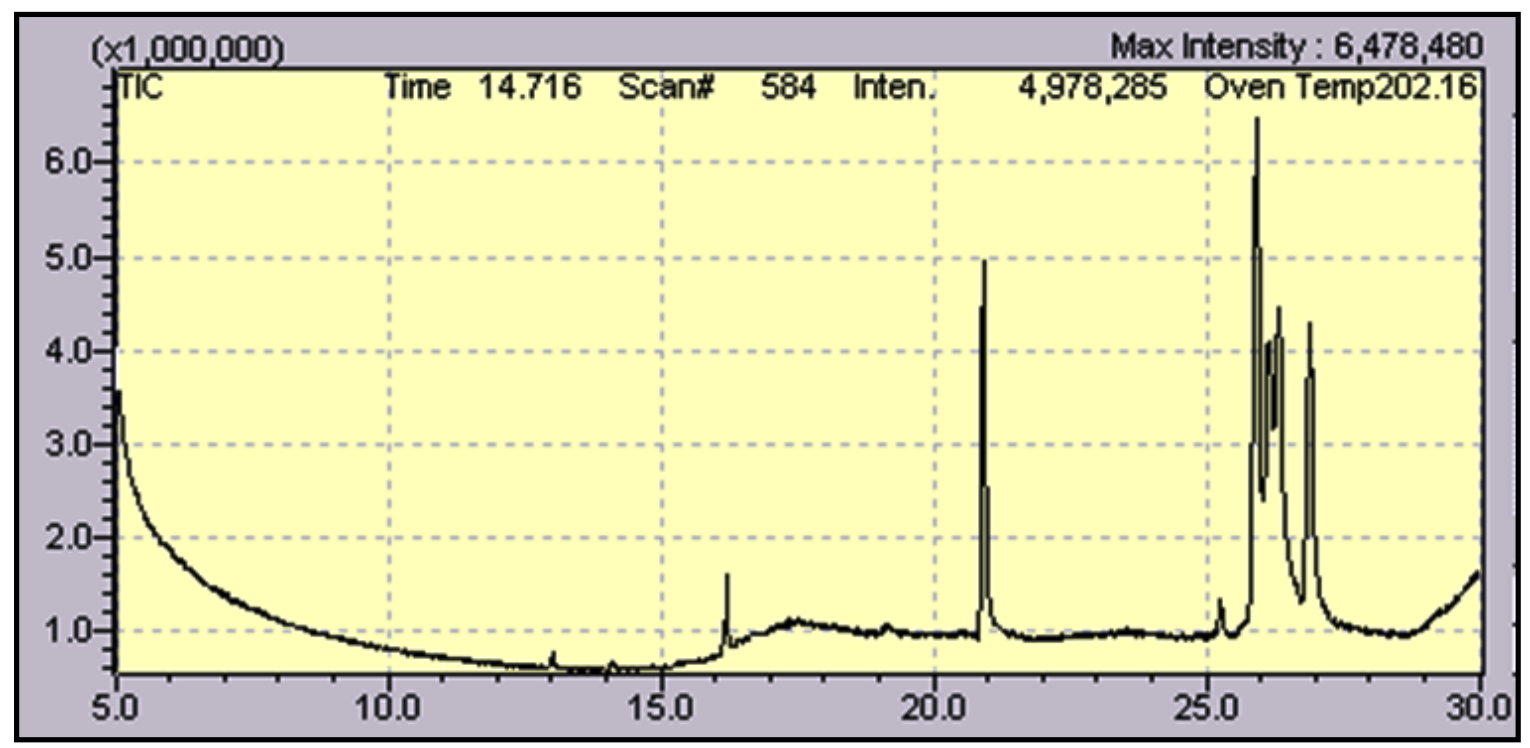

FIGURA 53 - Cromatograma do extrato da palha do café seca, diluída em diclorometano, obtido por GC/MS no modo SCAN.

O cromatograma do extrato obtido da palha do café in natura diluída em diclorometano pode ser observada na FIG.54.

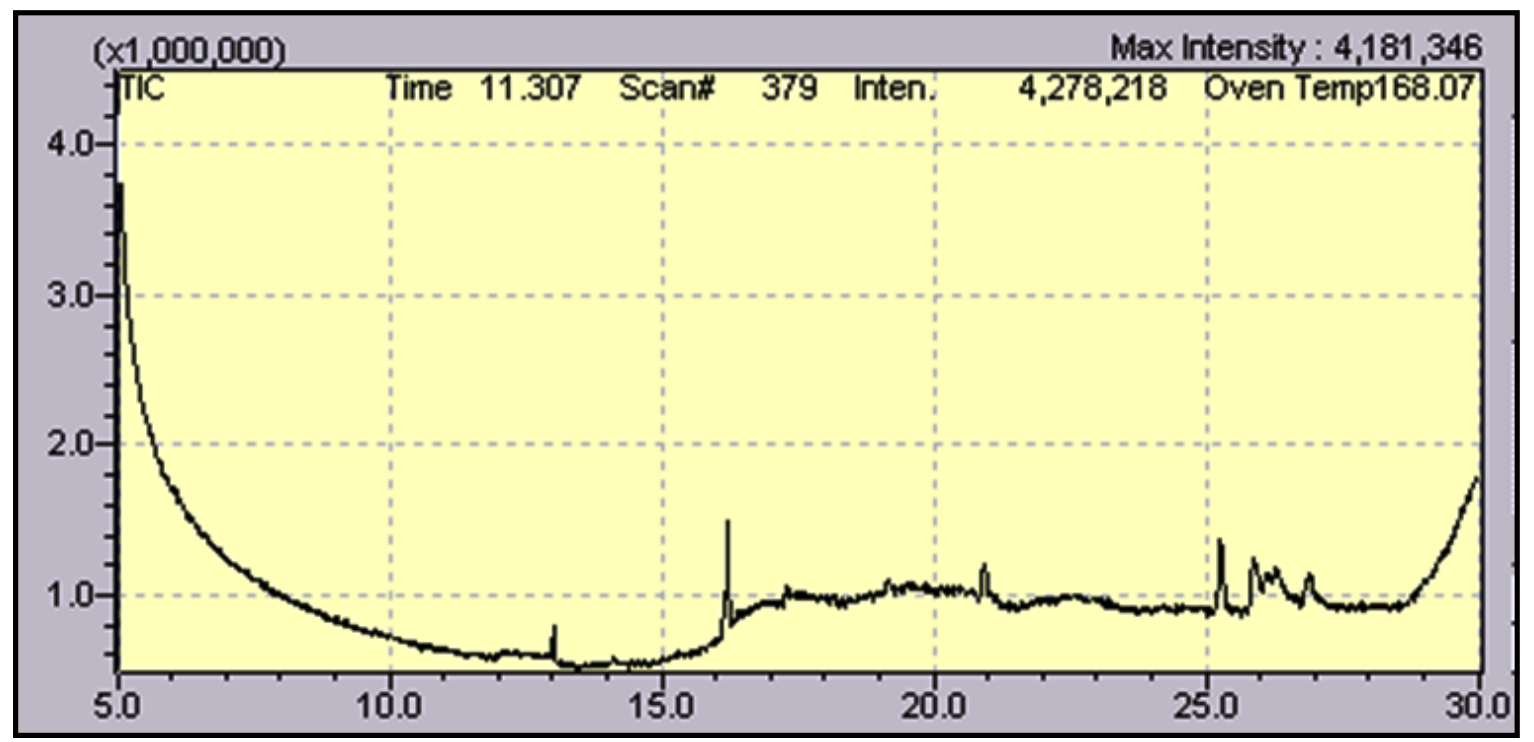

FIGURA 54 - Cromatograma do extrato da palha do café in natura, diluída em diclorometano, obtido por GC/MS no modo SCAN. 
Pode-se observar que, os resultados dos espestros de massa dos extratos obtidos das amostras secas e in natura da palha do café diluídas nos três solventes, foram comparados com o banco de dados da biblioteca NIST instalada no equipamento, sendo constatado uma similaridade nos espectros dessas amostras.

O primeiro composto determinado foi encontrado em um tempo de retenção de 13,02 min, conforme mostra o espectro da FIG. 55.

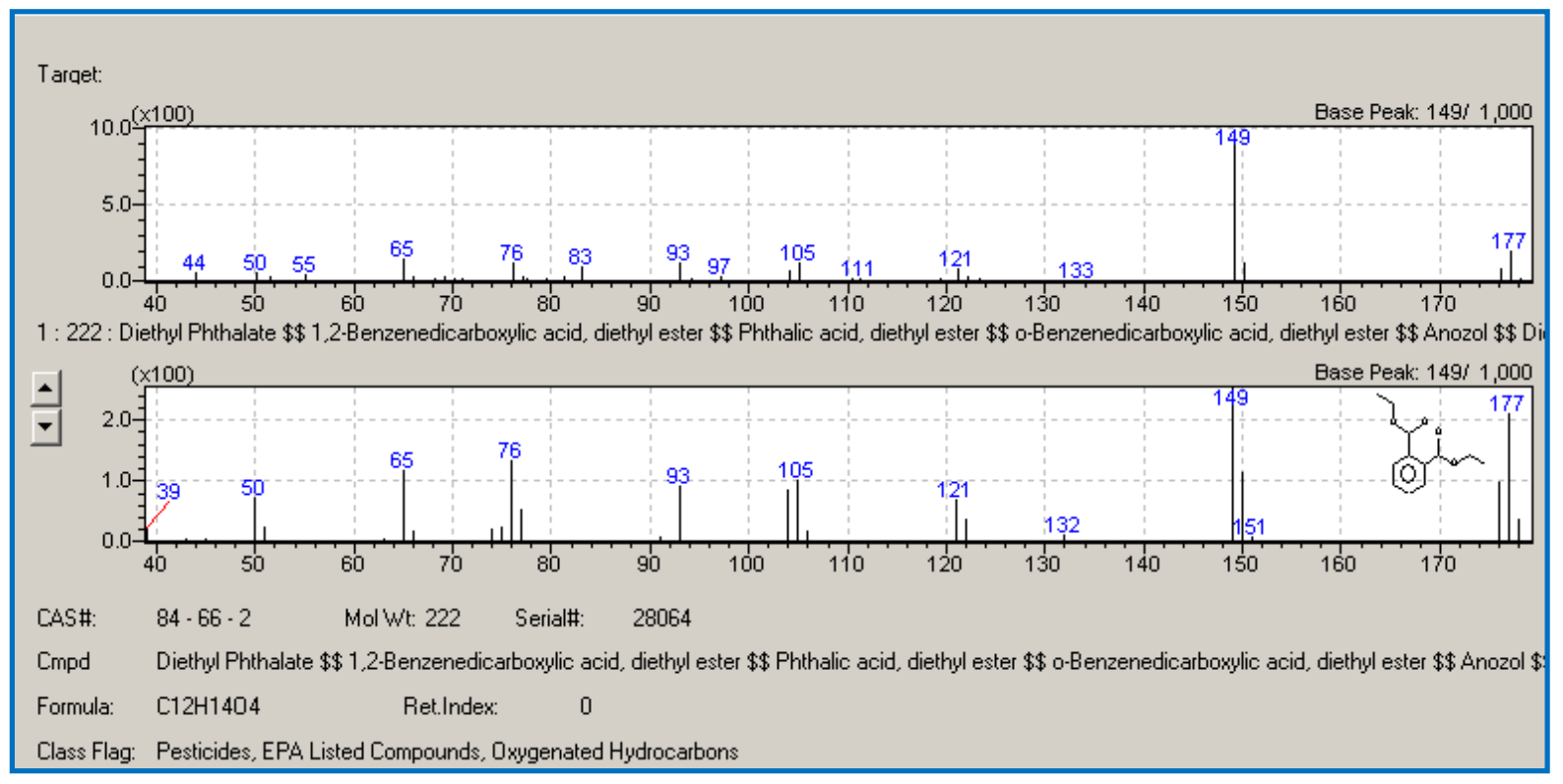

FIGURA 55 - Espectro de massas do composto Dietil ftalato.

Comparando-se o espectro de massas das amostras com 0 equivalente da biblioteca eletrônica NIST existente no software GC/MS solution versão 1.2 do equipamento utilizado, pode-se observar a presença do Dietil Ftalato, com similaridade de $83 \%$.

O segundo composto foi identificado em um tempo de retenção de 16,15 min, como mostra o espectro na FIG. 56. 


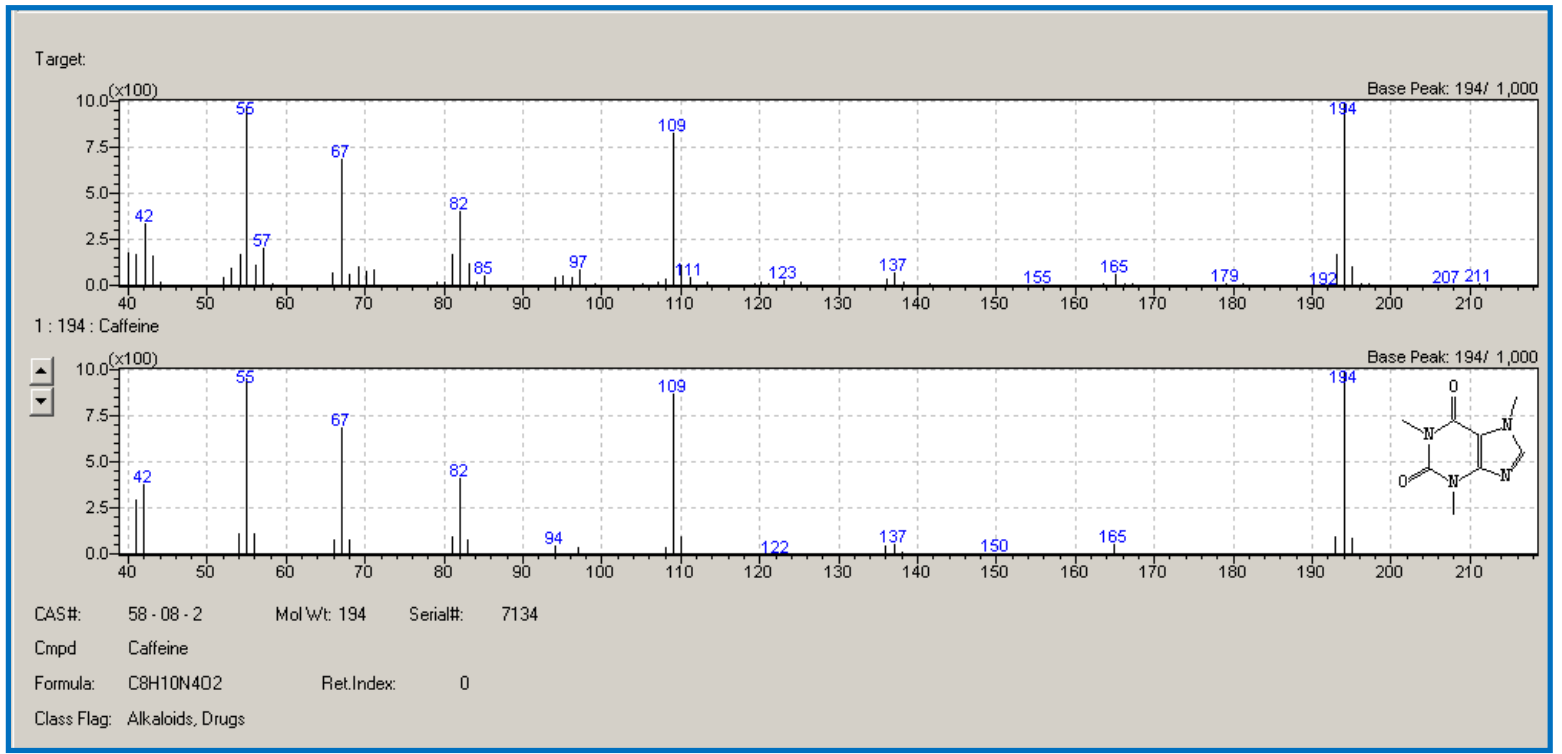

FIGURA 56 - Espectro de massas do composto Cafeína.

O espectro de massas das amostras apresentou um composto denominado Cafeína, com similaridade de $85 \%$ quando comparado à biblioteca eletrônica NIST existente no software.

O terceiro composto foi identificado em um tempo de retenção de 16,22 min, conforme mostra o espectro na FIG.57. 


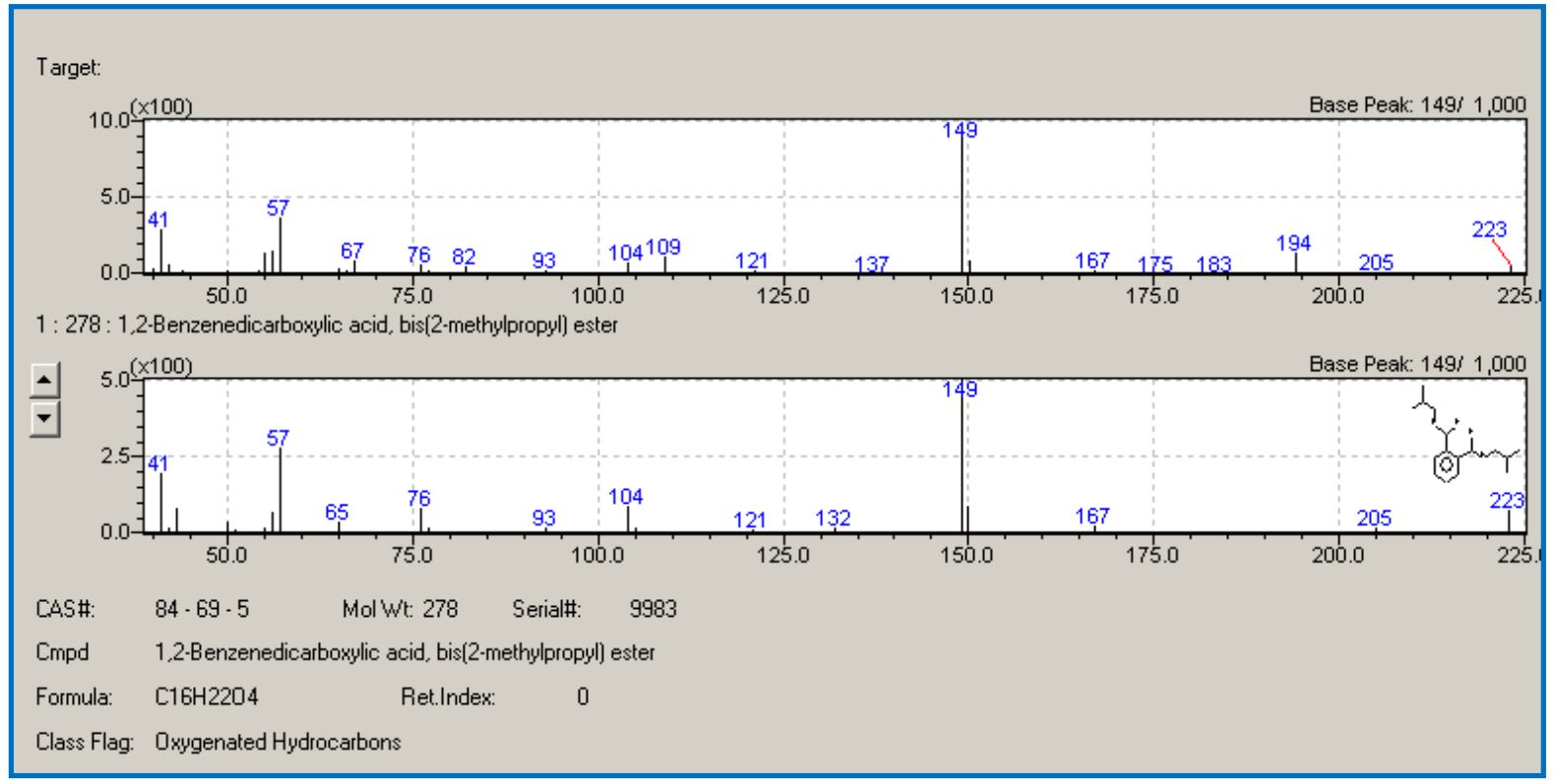

FIGURA 57 - Espectro de massas do composto Ácido 1,2-Benzenodicarboxilico, di(2-metilpropil) éster.

Comparando o espectro de massas das amostras citadas com a biblioteca digital NIST, foi encontrado um composto determinado como sendo Acido 1,2-Benzenodicarboxilico di (2-metilpropil) éster, com 82\% de similaridade.

O quarto composto foi identificado em um tempo de retenção de 20,92 min, conforme o espectro mostrado na FIG. 58. 


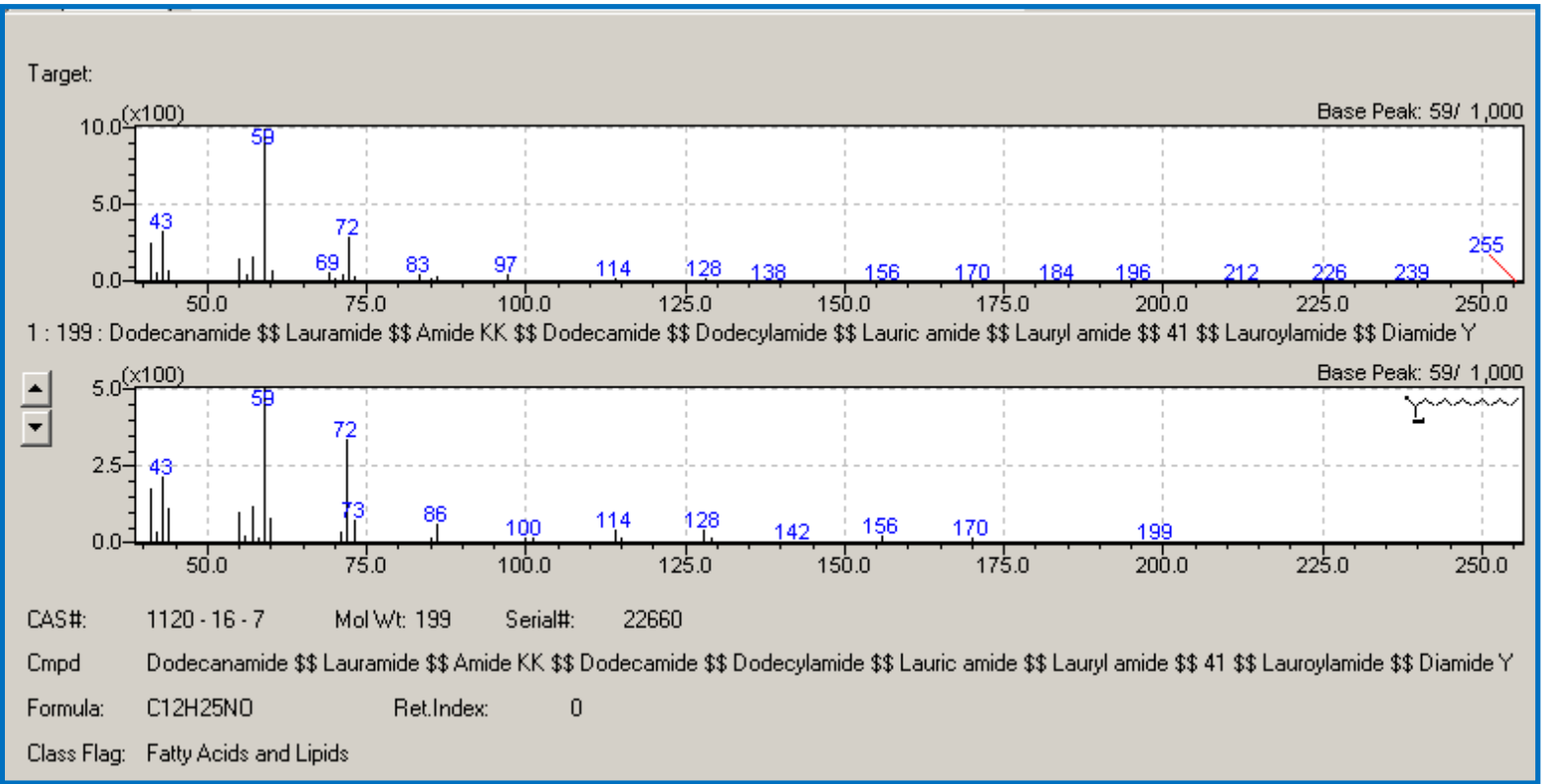

FIGURA 58 - Espectro de massas do composto Dodecanamida ou Lauramida.

Observando-se o espectro de massas das amostras, foi encontrado um composto denominado Dodecanamida ou Lauramida, com similaridade de $85 \%$, comparado à biblioteca digital.

O quinto composto determinado foi identificado em um tempo de retenção de 25,90 min, conforme espectro mostrado na FIG.59. 


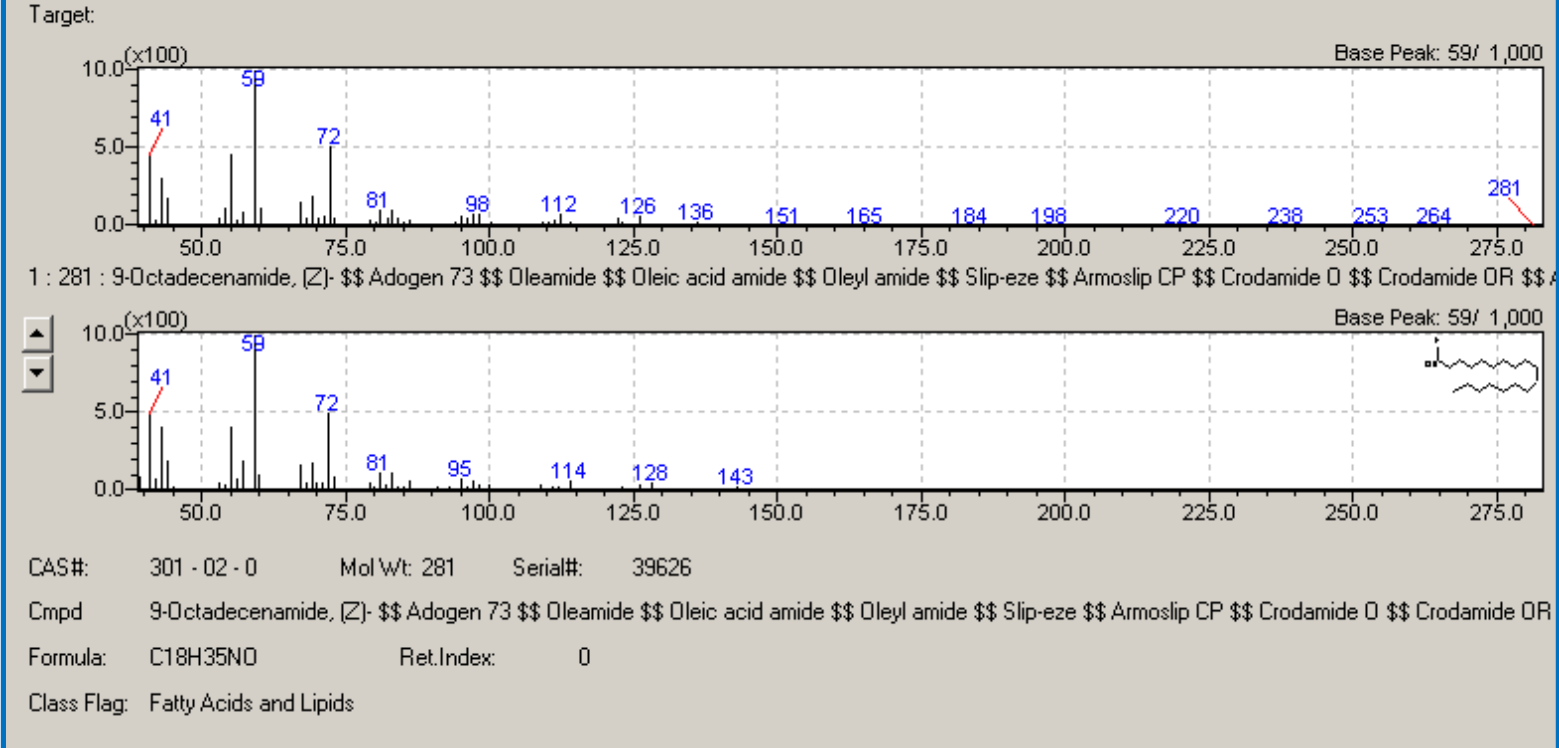

FIGURA 59 - Espectro de massas do composto 9-Octadecenamida ou Adogen 73.

O espectro de massas das amostras, comparado à biblioteca digital, apresentou um composto denominado 9-Octadecenamida ou Adogen 73, com similaridade de $91 \%$.

$\mathrm{Na}$ TAB.15, apresentam-se os principais compostos químicos identificados no extrato obtido da palha do café determinados por GC/MS com seus respectivos tempos de retenção, nomes, fórmula molecular, massa molecular e CAS number. 
TABELA 15 - Principais compostos químicos identificados no extrato obtido da palha do café determinados por GC/MS

\begin{tabular}{lcccc}
\hline T.R.(min) & Composto & $\begin{array}{c}\text { Fórmula } \\
\text { Química }\end{array}$ & M.M. & $\begin{array}{c}\text { CAS } \\
\text { number }\end{array}$ \\
\hline 13,02 & Dietil ftalato & $\mathrm{C}_{12} \mathrm{H}_{14} \mathrm{O}_{4}$ & 222 & $84-66-2$ \\
16,15 & 1,3,7 Trimetilxantina (Cafeína) & $\mathrm{C}_{8} \mathrm{H}_{10} \mathrm{~N}_{4} \mathrm{O}_{2}$ & 194 & $58-08-2$ \\
16,22 & $\begin{array}{c}\text { Ácido 1,2-Benzenodicarboxilico, } \\
\text { di(2-metilpropil) éster }\end{array}$ & $\mathrm{C}_{16} \mathrm{H}_{22} \mathrm{O}_{4}$ & 278 & $84-69-5$ \\
& $\begin{array}{c}\text { Dodecanamida (Lauramida) } \\
20,92\end{array}$ & $\mathrm{C}_{12} \mathrm{H}_{25} \mathrm{NO}$ & 199 & $1120-16-7$ \\
& $\begin{array}{c}\text { 9-Octadecenamida (Z)- } \\
\text { (Adogen73) }\end{array}$ & $\mathrm{C}_{18} \mathrm{H}_{35} \mathrm{NO}$ & 281 & $301-02-0$ \\
25,90 & & & & \\
\hline & & & & \\
\hline
\end{tabular}

Pode-se observar pelos resultados obtidos, que os compostos químicos mais evidentes encontrados no extrato obtido na palha do café foram os alcalóides do grupo das xantinas (cafeína), hidrocarbonetos oxigenados (dietil ftalato e ácido 1,2-benzenodicarboxílico di-2-metilpropil éster) e lipídeos (dodecanamida e 9-octadecenamida).

Na FIG.60 estão ilustradas as fórmulas estruturais dos compostos químicos presentes na palha do café identificados por GC/MS. 


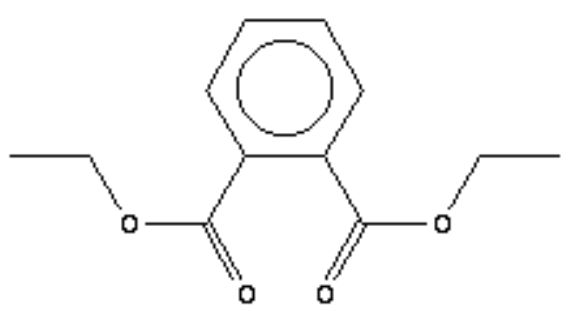

Dietil ftalato<smiles>CC(C)COC(=O)c1ccccc1C(=O)OCC(C)C</smiles>

Ácido 1,2-Benzenodicarboxilico, di(2metilpropil) éster<smiles>Cn1c(=O)c2c(ncn2C)n(C)c1=O</smiles>

1,3,7 Trimetilxantina

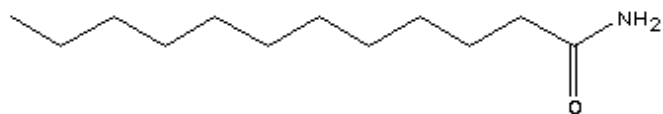

Dodecanamida<smiles>CCCCCCCCCCCCC(N)=O</smiles>

9-Octadecenamida

FIGURA 60 - Fórmula estrutural dos principais compostos químicos presentes na palha do café determinados por GC/MS. 


\subsection{Estudo dos principais parâmetros de processo}

\subsubsection{Pressão de alimentação do gás de aquecimento}

Estudou-se a variação de pressão de alimentação do gás de aquecimento do sistema em 4,8,5,5 e 6,4 kgf $/ \mathrm{cm}^{2}$.

Nessa etapa verificou-se que a uma pressão mais baixa $\left(4,8 \mathrm{kgf} / \mathrm{cm}^{2}\right)$ foi gerado um volume maior de bio-óleo em relação a outras operações, sendo o processo muito lento, ideal quando se visa a produção de bio-óleo.

A uma pressão de alimentação mais alta $\left(6,4 \mathrm{kgf} / \mathrm{cm}^{2}\right)$ houve escape de material volátil, vazamento de bio-óleo nas conexões, bem como a formação esporádica de labaredas na região da grelha perdendo-se calor na camisa do reator, comprometendo a segurança do procedimento, não se realizando outros estudos nesta pressão, pois os resultados não podem ser considerados fidedignos.

Quando se manteve a pressão de $5,5 \mathrm{kgf} / \mathrm{cm}^{2}$, obteve-se uma quantidade menor de bio-óleo, o processo foi mais rápido e o teor de voláteis maior. Com esta pressão de alimentação atingiram-se temperaturas elevadas em menor espaço de tempo, tornando-a mais propícia para a obtenção de hidrogênio, objeto deste estudo.

Na FIG.61 observa-se a variação do volume de bio-óleo nas pressões de 4,8, 5,5 kgf $/ \mathrm{cm}^{2}$ de alimentação do gás de aquecimento, em 18 diferentes bateladas escolhidas dentre as estudadas, que foram as mais representativas no processo de pirólise da palha do café. 


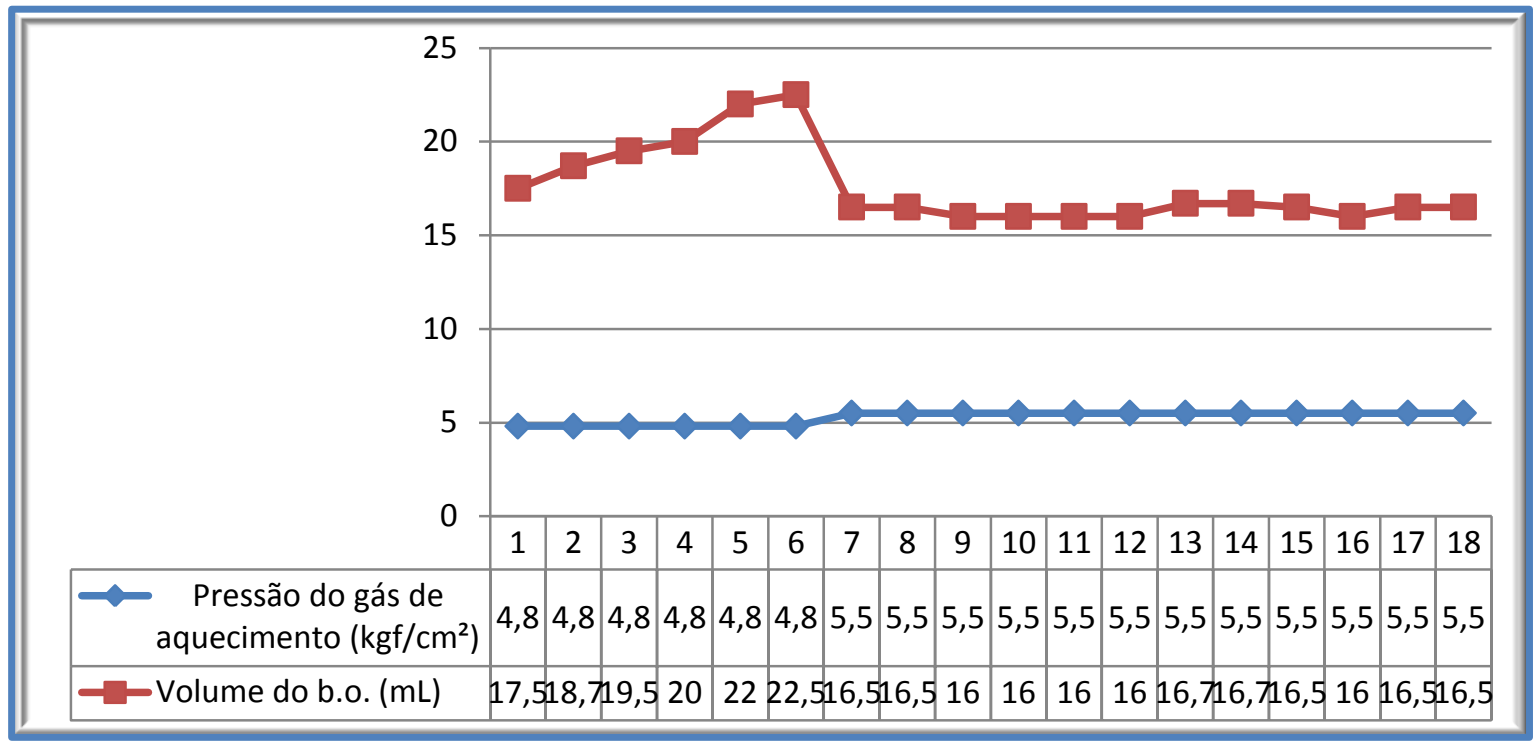

FIGURA 61- Variação do volume do bio-óleo nas pressões de 4,8 e $5,5 \mathrm{kgf} / \mathrm{cm}^{2}$ de alimentação do gás de aquecimento em 18 bateladas do processo de pirólise da palha do café.

À pressão de $4,8 \mathrm{kgf} / \mathrm{cm}^{2}$ nota-se uma variação considerável no volume de bio-óleo obtido na pirólise da palha do café, enquanto que à pressão de $5,5 \mathrm{~kg} / \mathrm{cm}^{2}$, os valores dos volumes obtidos são quase que constantes.

$\mathrm{Na}$ FIG.62 observa-se a variação da massa de cinzas com as pressões de 4,8,5,5 kgf $/ \mathrm{cm}^{2}$ de alimentação do gás de aquecimento, nas 18 bateladas.

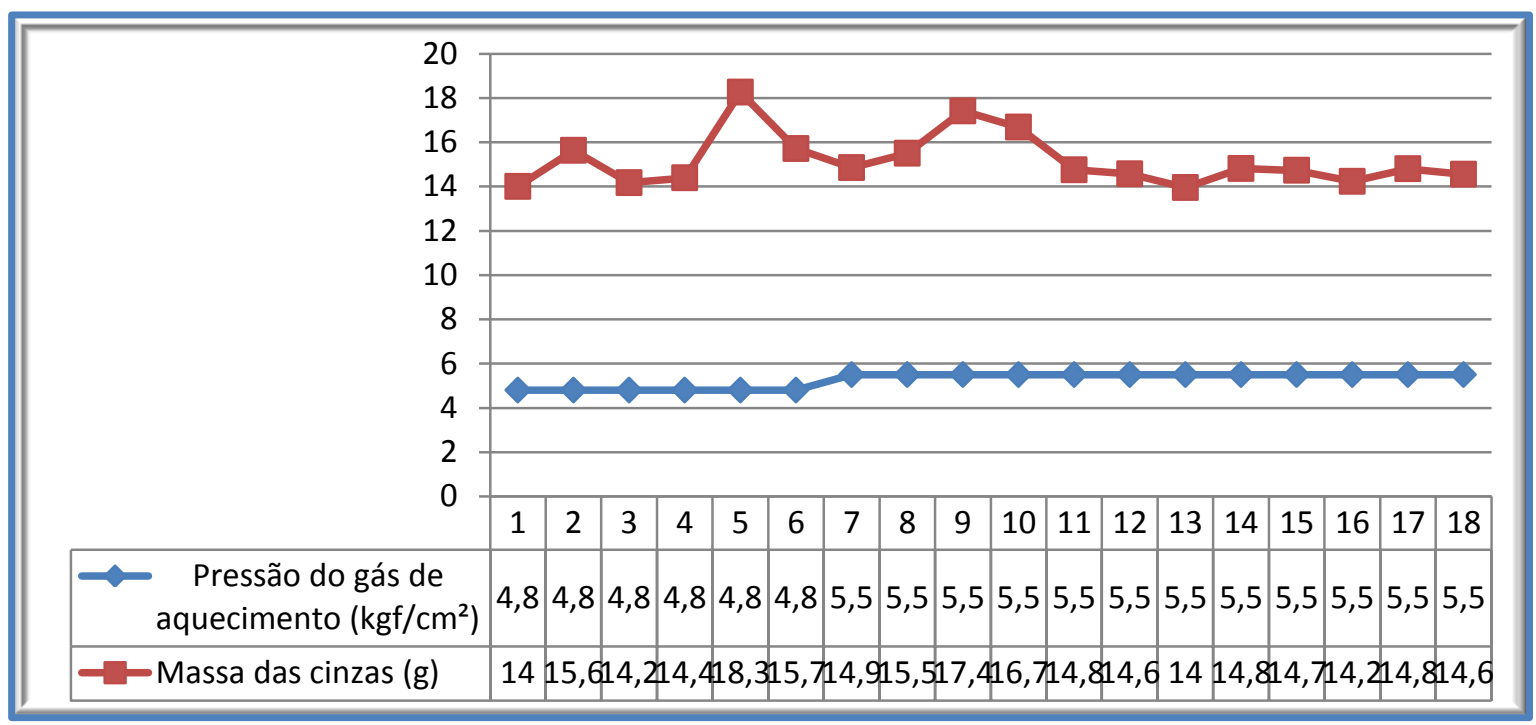

FIGURA 62 - Variação da massa de cinzas nas pressões de 4,8 e $5,5 \mathrm{kgf} / \mathrm{cm}^{2}$ de alimentação do gás de aquecimento, em 18 bateladas do processo de pirólise da palha do café. 
Quanto à massa de cinzas obtidas no processo de pirólise da palha do café, observou-se uma maior variação quando da utilização da pressão 4,8 $\mathrm{kgf} / \mathrm{cm}^{2}$; já a $5,5 \mathrm{kgf} / \mathrm{cm}^{2}$ as frações sólidas se mantiveram em um valor mais constante.

$\mathrm{Na}$ FIG.63, tem-se os percentuais de hidrogênio obtidos com as pressões de 4,8 e 5,5 kgf/ $/ \mathrm{cm}^{2}$ de alimentação do gás de aquecimento, nas 18 bateladas.

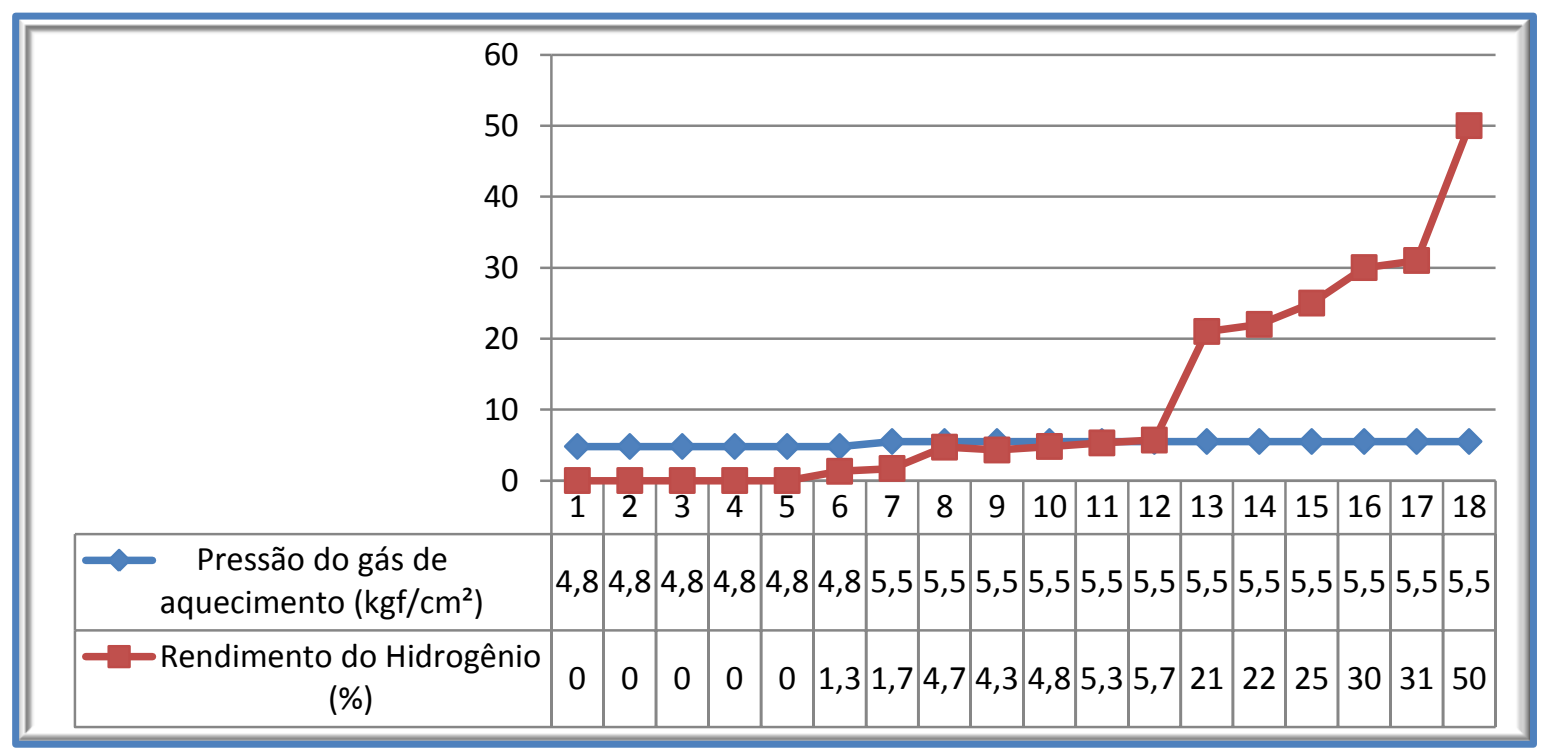

FIGURA 63 - Percentuais de hidrogênio obtidos nas pressões de 4,8 e $5,5 \mathrm{kgf} / \mathrm{cm}^{2}$ de alimentação do gás de aquecimento, nas 18 bateladas.

Pode-se notar que à pressão de $4,8 \mathrm{kgf} / \mathrm{cm}^{2}$, os valores do rendimento de hidrogênio foram nulos, ou não determinados. Isto pode ser devido às temperaturas não terem atingido o patamar suficiente de dissociação do hidrogênio. À pressão de $5,5 \mathrm{kgf} / \mathrm{cm}^{2}$ alguns resultados também foram de baixo rendimento, pois nestas bateladas, também não foram atingidas temperaturas maiores, o que será comentado no ítem 5.2.2.

O fato de os gráficos acima terem sido apresentados com um maior número de procedimentos à $5,5 \mathrm{kgf} / \mathrm{cm}^{2}$ se deveu ao fato de se ter observado, durante a realização dos experimentos, um maior rendimento de hidrogênio na 
fase gasosa para esse valor, levando à adoção dessa pressão do gás de aquecimento como parâmetro consolidado.

\subsubsection{Temperatura de operação e taxa de aquecimento}

O estudo da influência da temperatura de operação no processo de pirólise da palha do café é de vital importância, pois o controle da temperatura, determina as faixas de atuação que melhor respondem aos rendimentos dos produtos de interesse do processo.

Para que se obtivesse as temperaturas mais próximas do ideal, ou seja, nos valores próximos de $700^{\circ} \mathrm{C}$ onde o hidrogênio é preferencialmente obtido, estudou-se o tempo necessário para que se atingisse esse patamar.

$\mathrm{Na}$ FIG.64, observam-se as temperaturas máximas atingidas no processo de pirólise da palha do café e o tempo para atingí-las em 18 diferentes bateladas, não havendo correspondência na numeração destas, com as utilizadas no ítem 5.2.1. As bateladas 1, 2, 4, 6, 14 e16 correspondem às processadas a 4,8 $\mathrm{kgf} / \mathrm{cm}^{2}$ e as demais a $5,5 \mathrm{kgf} / \mathrm{cm}^{2}$.

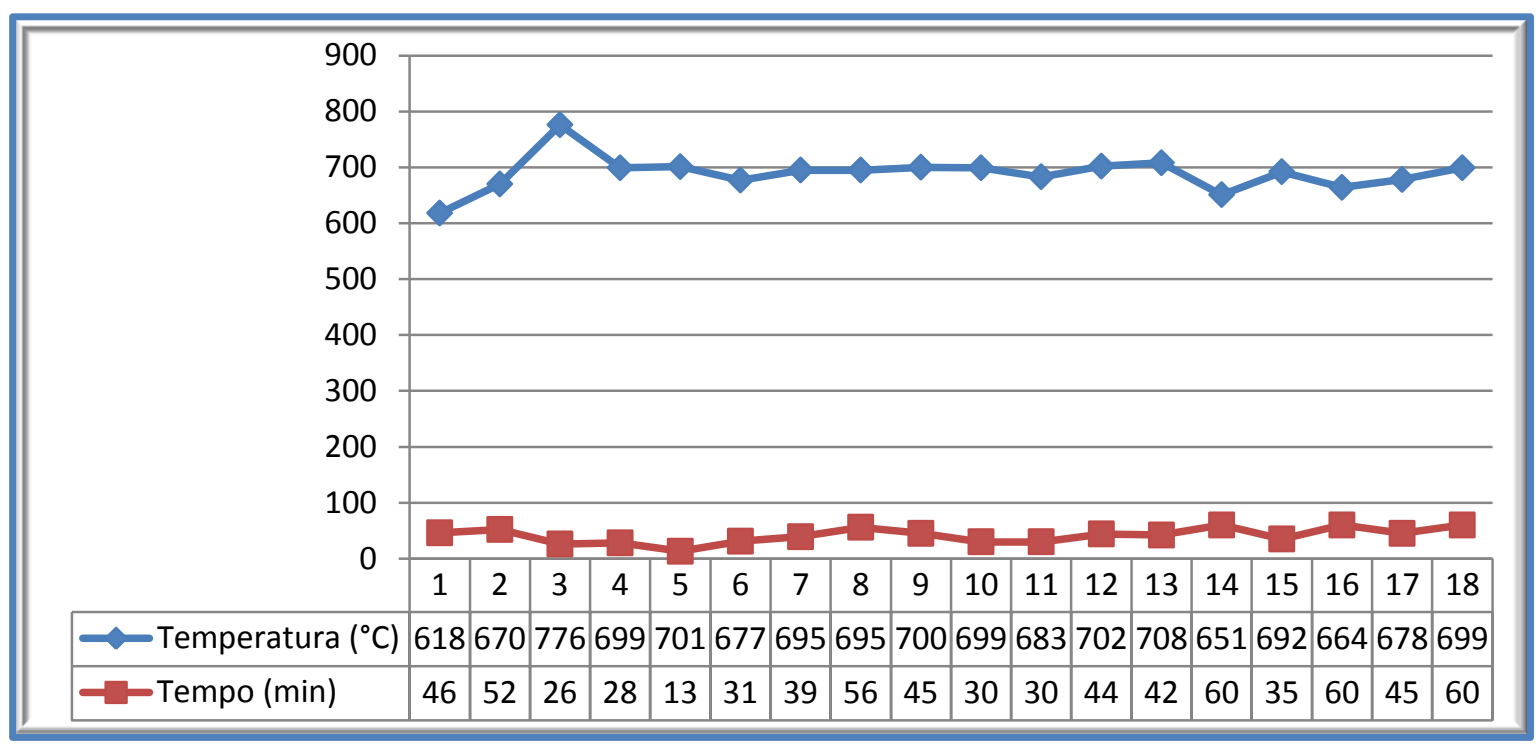

FIGURA 64 - Temperaturas máximas atingidas no processo de pirólise da palha do café e o tempo para atingí-las em 18 diferentes bateladas. 
A partir do gráfico da FIG.64 pode-se inferir que, de um modo geral, o tempo necessário para que o processo de pirólise da palha do café alcançasse temperaturas entre 692 e $708{ }^{\circ} \mathrm{C}$ foi na faixa de 44 minutos considerando-se a média entre as bateladas $7,8,9,10,12,13,15,18$, processadas a $5,5 \mathrm{kgf} / \mathrm{cm}^{2}$ (43,85 min).

As bateladas 1, 2, 14 e 16 processadas a $4,8 \mathrm{kgf} / \mathrm{cm}^{2}$ ficaram numa faixa de temperatura menor do que a esperada, levando mais tempo para atingir suas respectivas temperaturas máximas.

Na FIG.65 apresenta-se a variação da temperatura de operação com o tempo, nas bateladas de 1 a 9. Na FIG.66 tem-se o mesmo para as bateladas de 10 a 18.

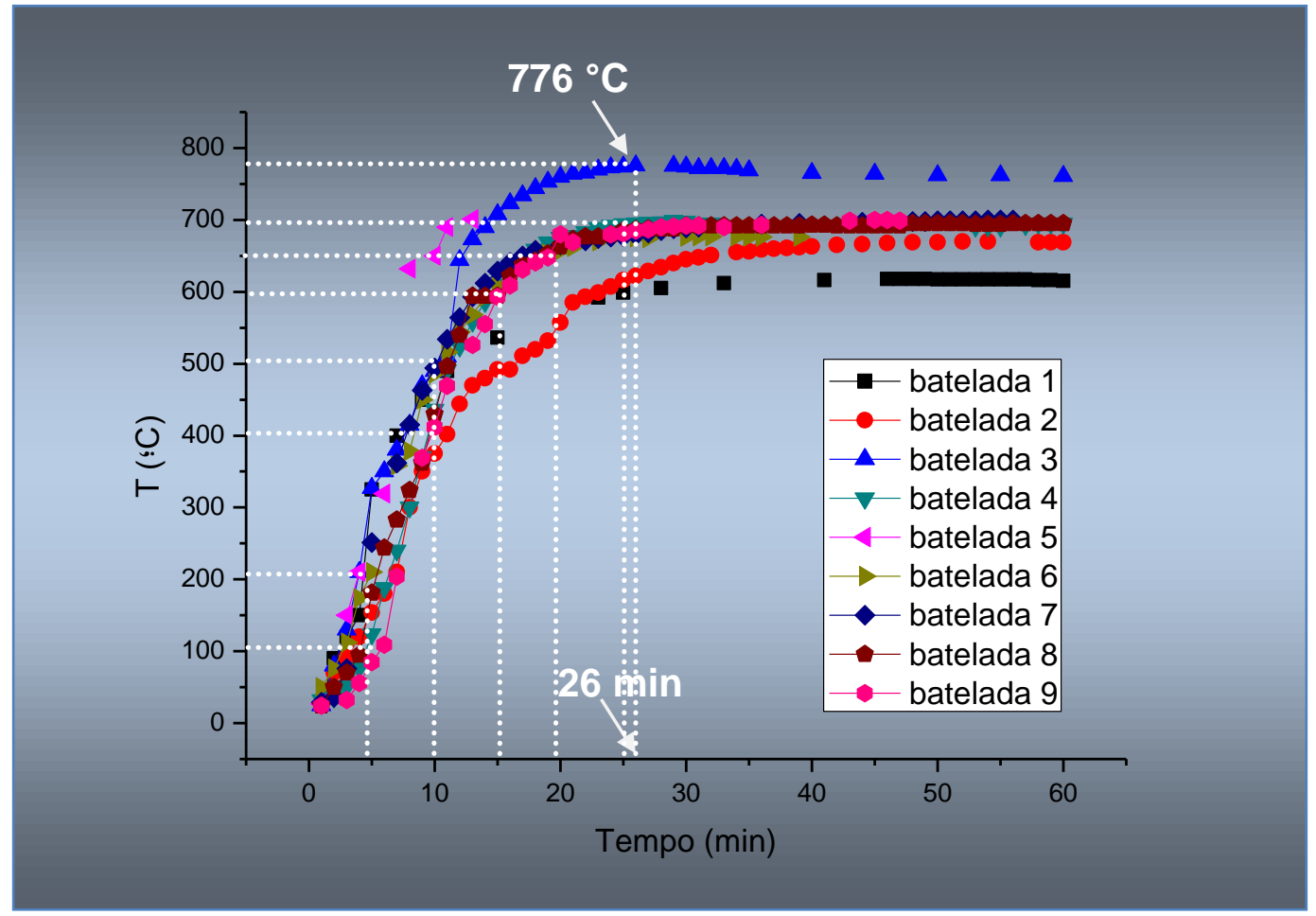

FIGURA 65 - Temperatura de operação e taxa de aquecimento (bateladas 1 a 9) da pirólise da palha do café. 


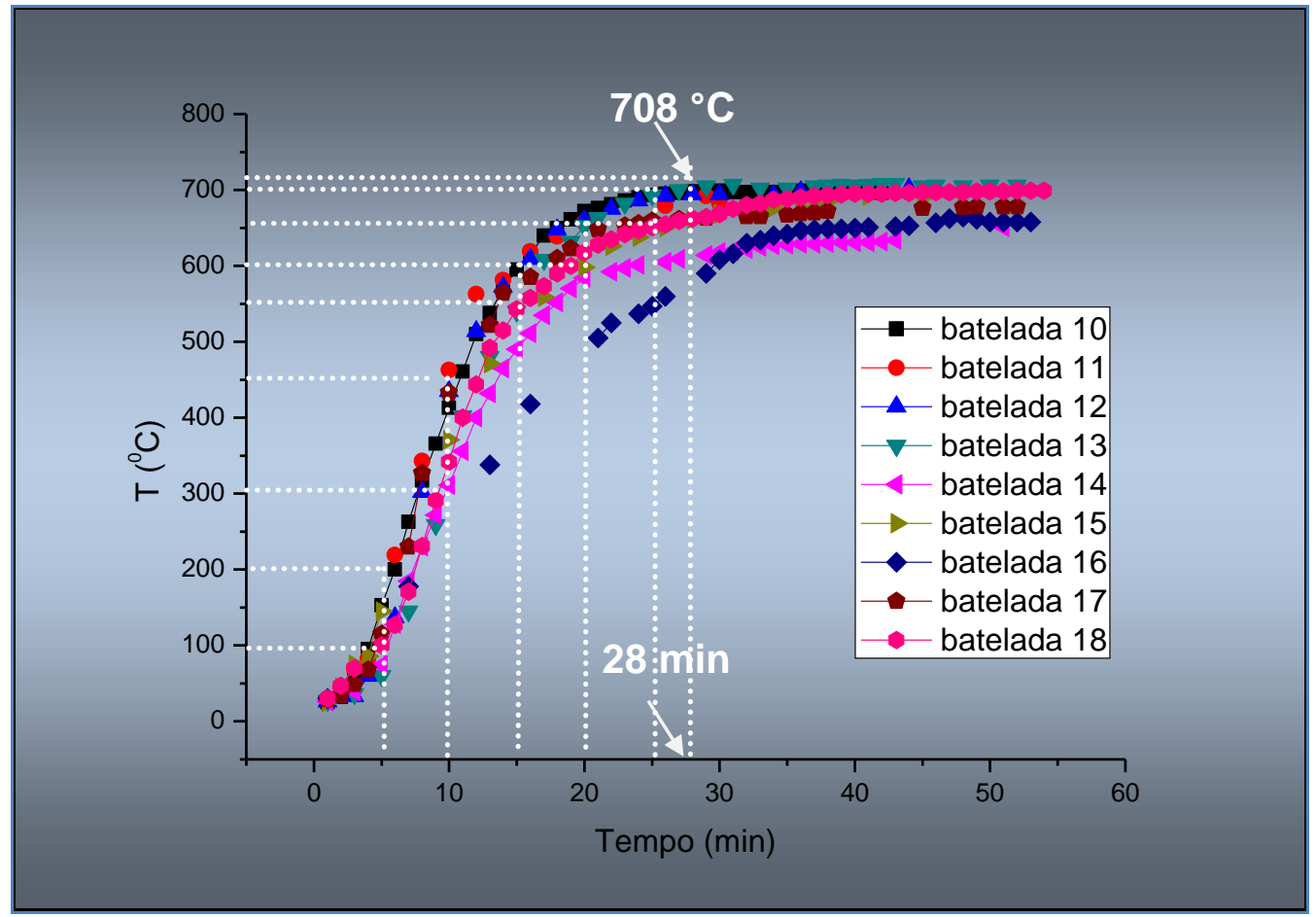

FIGURA 66 - Temperatura de operação e taxa de aquecimento (bateladas 10 a 18) da pirólise da palha do café.

Pode-se observar quanto às temperaturas máximas atingidas, bem como a taxa de aquecimento, que se evidenciam as bateladas 3 e 13 como as de maior taxa de aquecimento e as que alcançaram os maiores patamares de temperaturas. Mas, por observações durante a realização do processo, considerou-se apenas a número 13 como a melhor, pois embora em ambos os casos a pressão de alimentação do gás de aquecimento tenha sido de $5,5 \mathrm{kgf} / \mathrm{cm}^{2}$ e a massa da palha de café de $54 \mathrm{~g}$, na batelada 3 houve um vazamento pela conexão que liga o reator de pirólise ao condensador, evidenciando uma perda significativa de material volátil condensável e não condensável.

$\mathrm{Na}$ FIG.67, pode-se observar a taxa de aquecimento média das bateladas de 1 a 9 no processo de pirólise da palha do café. 


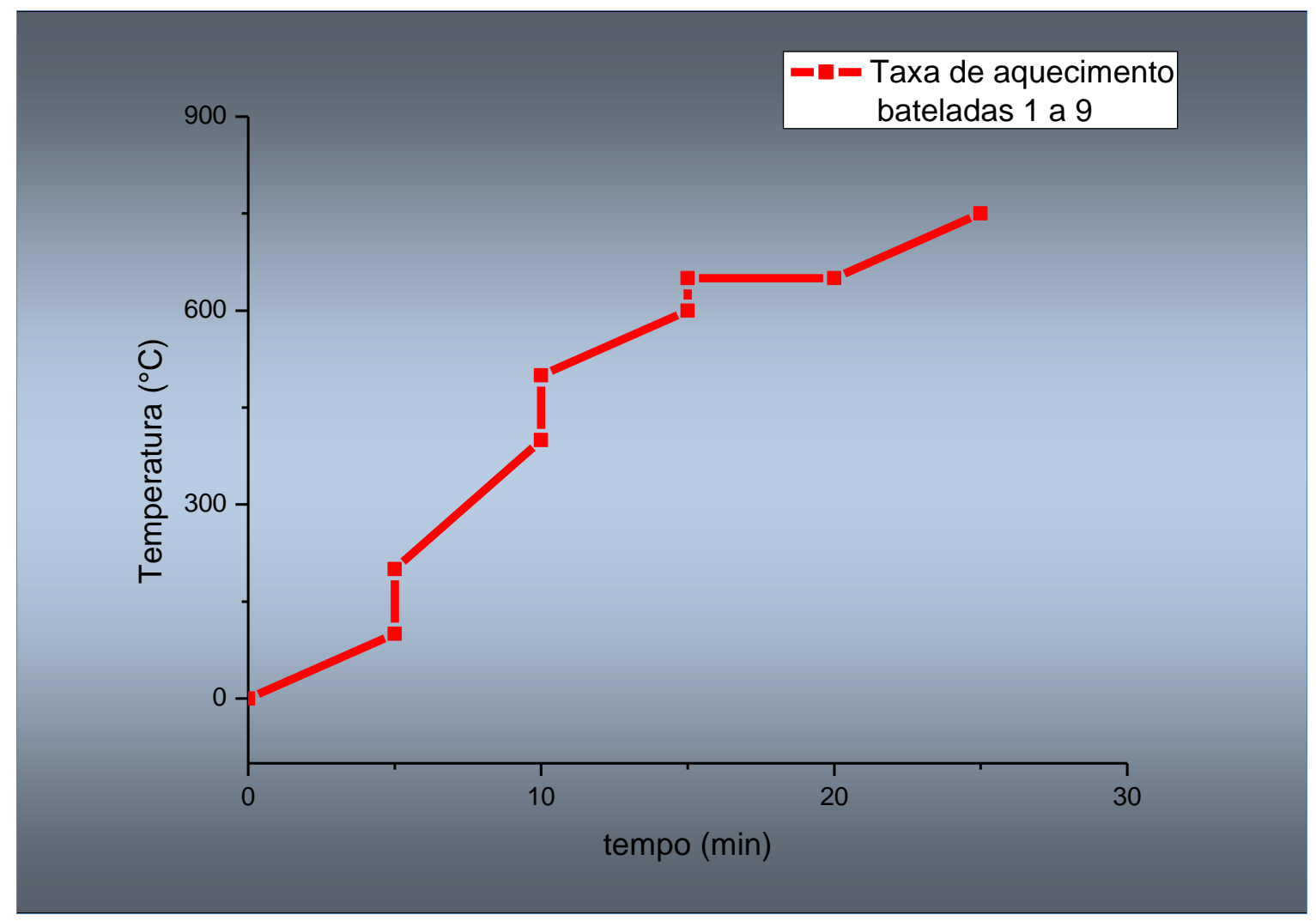

FIGURA 67- Taxa de aquecimento média das bateladas de 1 a 9 no processo de pirólise da palha do café.

A média da taxa de aquecimento das bateladas de 1 a 9 no processo de pirólise da palha do café foi estimada em função dos gráficos das temperaturas representada na FIG. 65 em pontilhado branco.

Pode-se observar que a taxa de aquecimento média foi de $20{ }^{\circ} \mathrm{C} / \mathrm{min}$ com uma evolução da temperatura de operação em função do tempo até a temperatura de $100{ }^{\circ} \mathrm{C}$ permanecendo na mesma taxa até $200{ }^{\circ} \mathrm{C}$. Em seguida nota-se um aumento para uma taxa de $40{ }^{\circ} \mathrm{C} / \mathrm{min}$ até $400{ }^{\circ} \mathrm{C}$, voltando à faixa de $20{ }^{\circ} \mathrm{C} /$ min entre 400 e $500{ }^{\circ} \mathrm{C}$ e de 500 a $600{ }^{\circ} \mathrm{C}$, diminuindo para $10{ }^{\circ} \mathrm{C} / \mathrm{min}$ de $600{ }^{\circ} \mathrm{C}$ a $650{ }^{\circ} \mathrm{C}$ e de 650 às proximidades dos $700{ }^{\circ} \mathrm{C}$.

$\mathrm{Na}$ FIG.68, pode-se observar a taxa de aquecimento média do processo de pirólise da palha do café em função da temperatura de operação, das bateladas de 10 a 18 . 


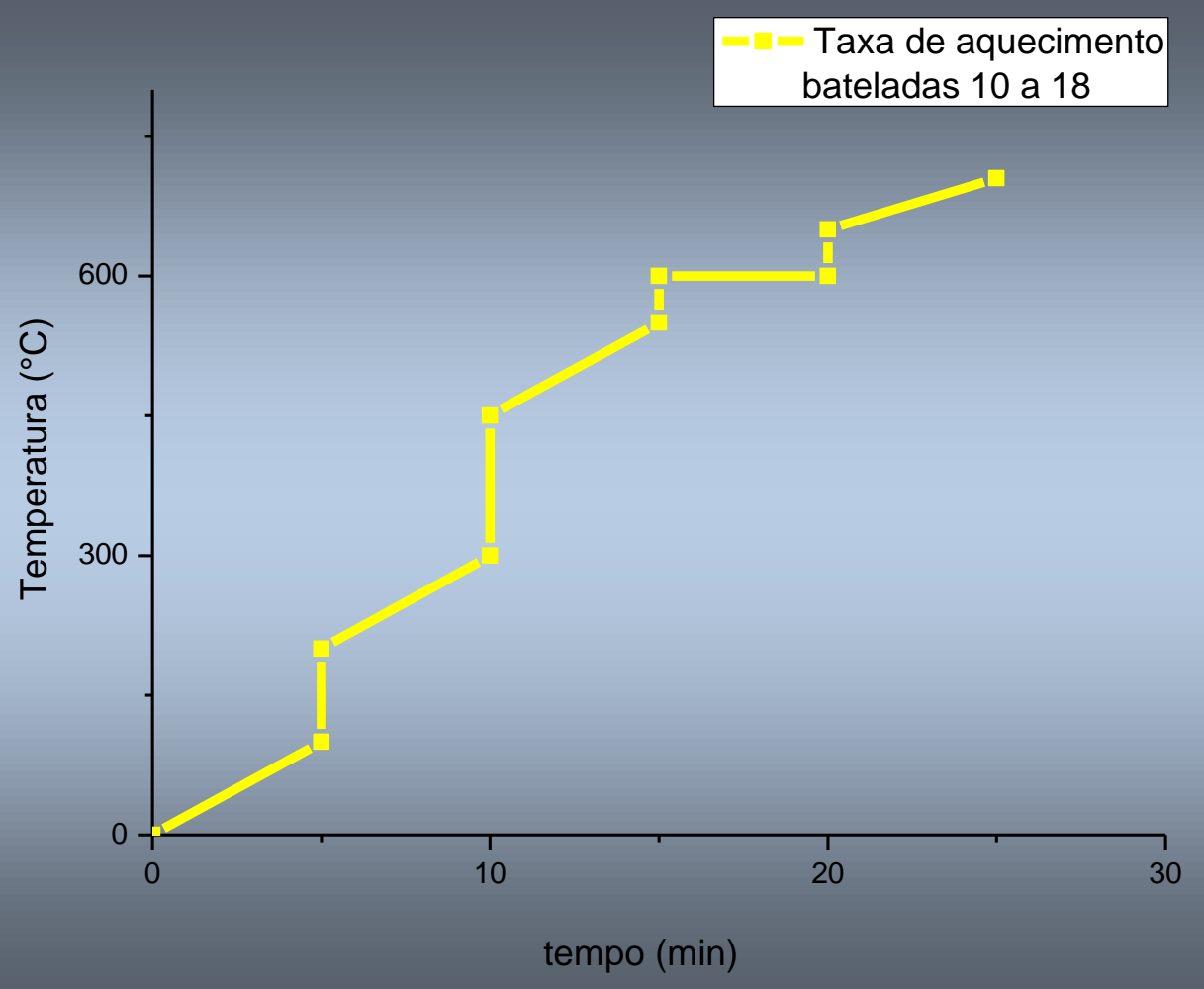

FIGURA 68 - Taxa de aquecimento média das bateladas de 10 a 18 no processo de pirólise da palha do café.

A média da taxa de aquecimento das bateladas de 10 a 18 no processo de pirólise da palha do café foi estimada em função dos gráficos das temperaturas representadas na FIG. 66 em pontilhado branco.

Pode-se observar que a taxa de aquecimento foi de $20{ }^{\circ} \mathrm{C} / \mathrm{min}$ com uma evolução da temperatura de operação em função do tempo até $100{ }^{\circ} \mathrm{C}$, permanecendo na mesma taxa até $200{ }^{\circ} \mathrm{C}$, repetindo esta taxa de 200 a $300{ }^{\circ} \mathrm{C}$. Em seguida houve um aumento para uma taxa de $30{ }^{\circ} \mathrm{C} / \mathrm{min}$ de 300 a $450{ }^{\circ} \mathrm{C}$, voltando à faixa de $20{ }^{\circ} \mathrm{C} / \mathrm{min}$ entre 450 e $550{ }^{\circ} \mathrm{C}$, diminuindo a taxa para $10^{\circ} \mathrm{C} /$ min de 600 a $650^{\circ} \mathrm{C}$ e de 650 às proximidades dos $700{ }^{\circ} \mathrm{C}$.

$\mathrm{Na}$ continuação dos estudos relativos aos acontecimentos térmicos, por ser o sistema de condensação dos produtos da pirólise todo em vidro, houve possibilidade de se estudar as fases de condensação da água e do bio-óleo nas 18 bateladas. 
Na FIG.69, observa-se a média das temperaturas de condensação dos produtos de menor temperatura de ebulição em função do tempo, das 18 bateladas, no processo de pirólise da palha do café.

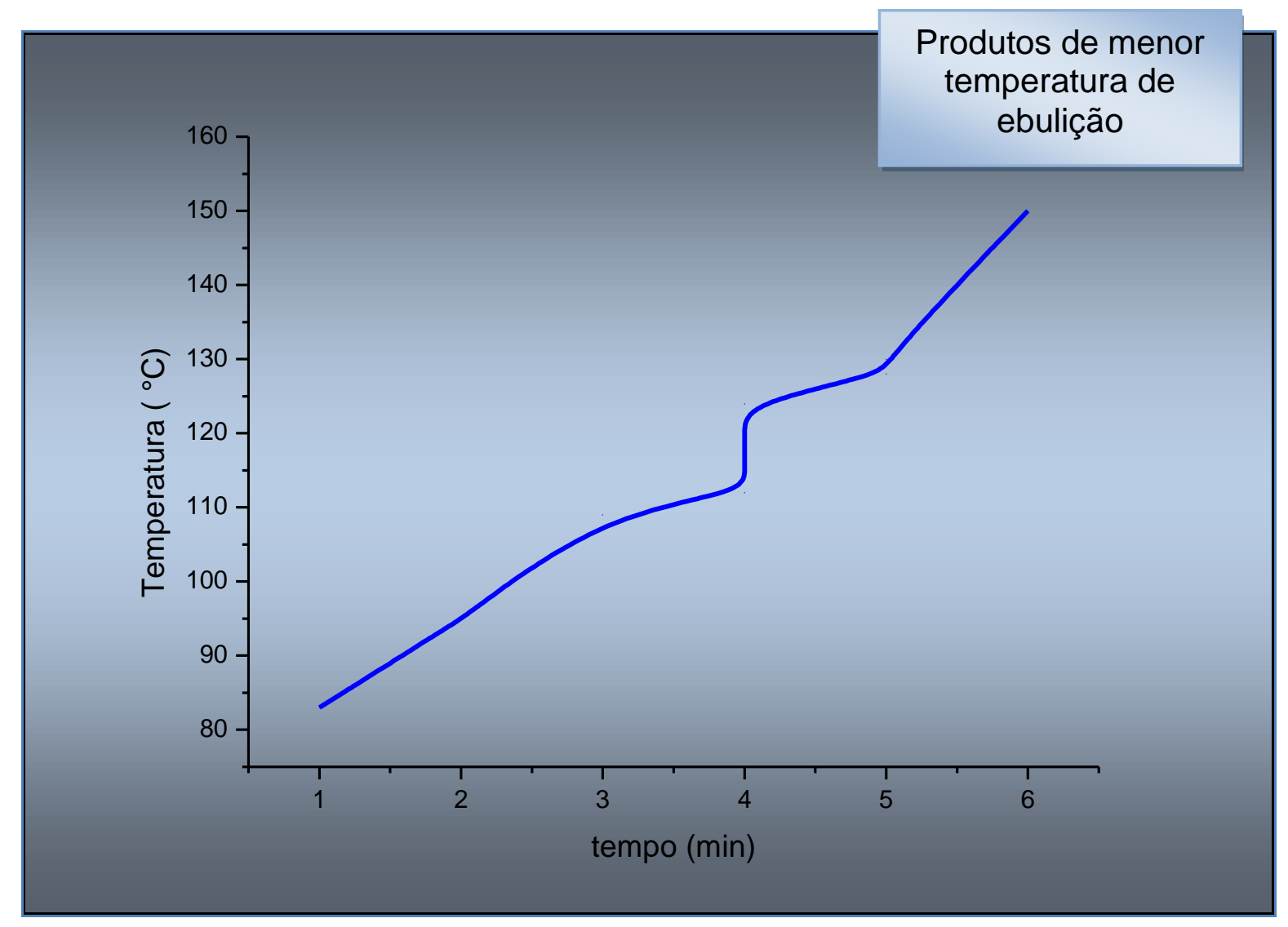

FIGURA 69 - Média das temperaturas de condensação dos produtos de menor temperatura de ebulição em função do tempo.

A partir de aproximadamente $85{ }^{\circ} \mathrm{C}$ até $150{ }^{\circ} \mathrm{C}$, pode-se verificar o processo de condensação dos compostos de menor ponto de ebulição, corroborando os resultados termogravimétricos, que inferem a faixa entre 25 a $150{ }^{\circ} \mathrm{C}$ como sendo o primeiro evento da perda de massa da amostra da palha do café. 
Findo esse primeiro processo de vaporização, observou-se a formação de uma névoa amarelada que preencheu tanto o condensador, assim como o coletor da fase líquida, para logo em seguida acontecer a condensação do bioóleo.

$\mathrm{Na}$ FIG.70, observam-se os valores médios das temperaturas de condensação do bio-óleo em função do tempo, das 18 bateladas, no processo de pirólise da palha do café.

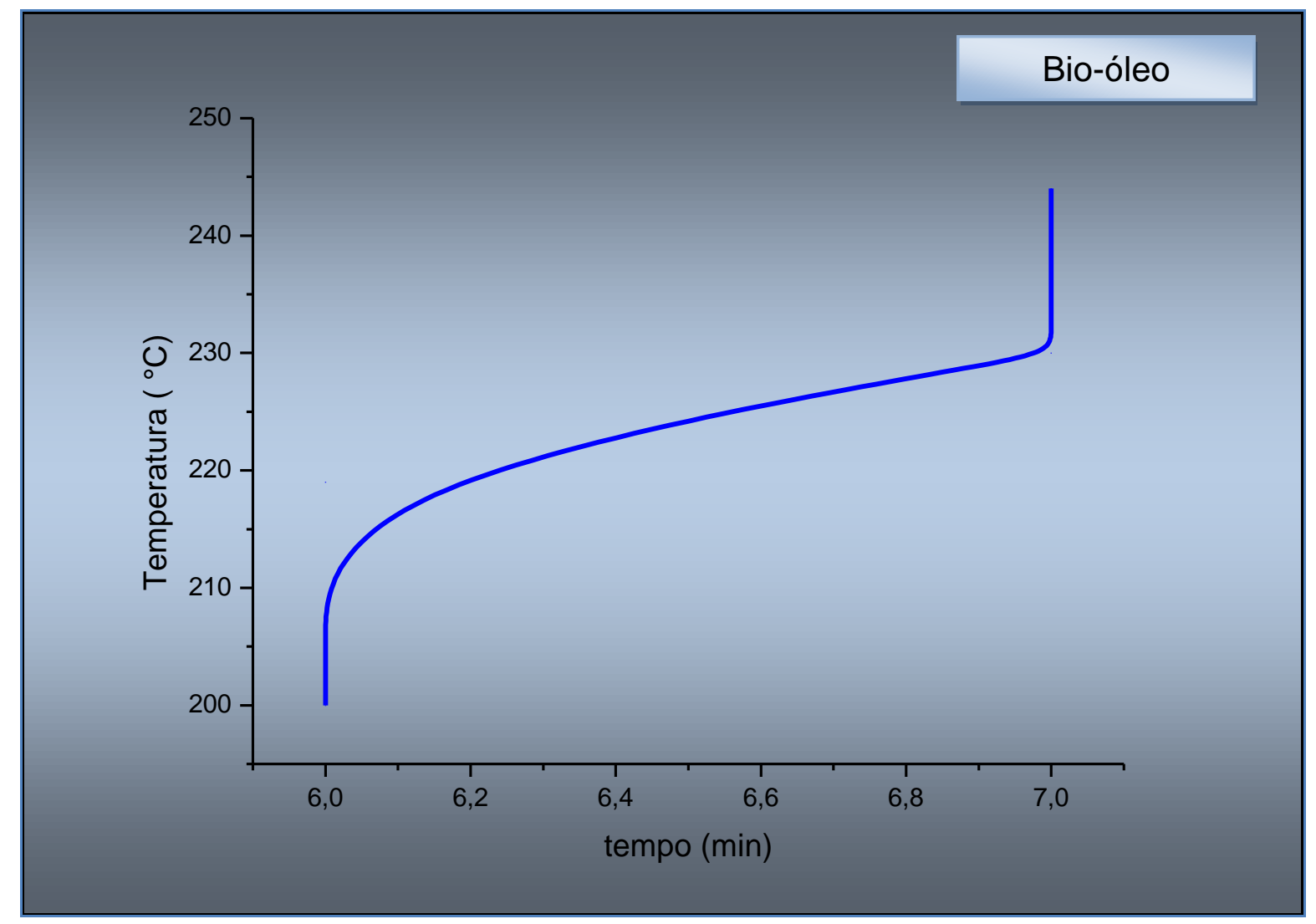

FIGURA 70 - Média da temperatura da condensação do bio-óleo em função do tempo no processo.

Ao final da vaporização dos compostos de baixo ponto de ebulição, em uma temperatura de aproximadamente $150{ }^{\circ} \mathrm{C}$, começou a vaporização e consequente condensação do bio-óleo, na faixa que foi de $200{ }^{\circ} \mathrm{C}$ até $244{ }^{\circ} \mathrm{C}$. A 
partir dessa temperatura, o processo de pirólise continuou até que houvesse a gaseificação intensiva dos voláteis condensáveis, chegando então a temperaturas mais elevadas para que se obtivessem os voláteis não condensáveis da qual o hidrogênio faz parte.

\subsubsection{Rendimento gravimétrico}

O rendimento gravimétrico médio $(R G)$ do processo de pirólise é uma relação entre a massa das cinzas produzidas (RG sólido), ou do volume de bioóleo obtido (RG líquido), pela massa da palha do café utilizada na alimentação do sistema.

Na TAB.16 tem-se o rendimento gravimétrico médio das fases em questão.

TABELA 16 - Rendimento gravimétrico médio das fases sólida e líquida da pirólise da palha do café

\begin{tabular}{cccc}
\hline Pressão & Massa & RG sol. & RG liq. \\
& & & \\
$\mathbf{k g f} / \mathbf{c m}^{2}$ & $(\mathrm{~g})$ & $(\%)$ & $(\%)$ \\
\hline & & & \\
& & & \\
4,8 & 54 & & \\
& & & \\
& & & \\
5,5 & & & \\
& & & \\
\end{tabular}

Pode-se observar a partir dos dados da TAB.16, que quando se utilizou a pressão de alimentação do gás do sistema em torno de $4,8 \mathrm{kgf} / \mathrm{cm}^{2}$, obteve-se 
maior quantidade de bio-óleo. O processo nesse caso foi mais lento, levando aproximadamente $1 \mathrm{~h} 15 \mathrm{~min}$ para se atingir a melhor temperatura de obtenção do hidrogênio $\left(\sim 700{ }^{\circ} \mathrm{C}\right)$, ao passo que para uma pressão maior, no caso $5,5 \mathrm{kgf} / \mathrm{cm}^{2}$, obteve-se um rendimento menor da fase líquida, mas o processo foi mais rápido, sendo necessários apenas 44 min para se atingir a temperatura desejada.

\subsection{Caracterização dos produtos do processo de pirólise}

\subsubsection{Análise elementar das cinzas}

$\mathrm{Na}$ TAB.17 apresentam-se os resultados da média do teor percentual de carbono $(C)$, hidrogênio $(H)$ e nitrogênio $(N)$, das amostras das cinzas do processo de pirólise, em função da pressão de alimentação do gás de aquecimento do sistema.

TABELA 17 - Dados da análise elementar média das cinzas obtidas no processo de pirólise da palha do café

\begin{tabular}{cccccc}
\hline Pressão & Massa & T máx. & $\mathbf{C}$ & $\mathbf{H}$ & $\mathbf{N}$ \\
$\mathbf{k g f} / \mathbf{c m}^{2}$ & $(\mathbf{g})$ & $\left({ }^{0} \mathrm{C}\right)$ & $(\%)$ & $(\%)$ & $(\%)$ \\
\hline 4,8 & 54 & 670 & 21,84 & 1,33 & 0,70 \\
& & & & & \\
5,5 & 54 & 708 & 21,21 & 1,10 & 0,68 \\
\hline
\end{tabular}


A partir dos dados da análise $\mathrm{CHN}$ das cinzas, pode-se verificar que quando a pressão de operação é menor, o teor de hidrogênio é maior, ao passo que quando se utiliza uma pressão de $5,5 \mathrm{kgf} / \mathrm{cm}^{2}$ na decomposição térmica da palha do café, o teor de hidrogênio é menor, corroborando o resultado do rendimento gravimétrico da TAB.16.

\subsubsection{Caracterização do bio-óleo por GC/MS}

\subsubsection{Bio-óleo}

Nas FIG.71 e 72, registram-se os cromatogramas do bio-óleo deixado em repouso por um período maior e menor do que 100 dias de decantação, respectivamente.

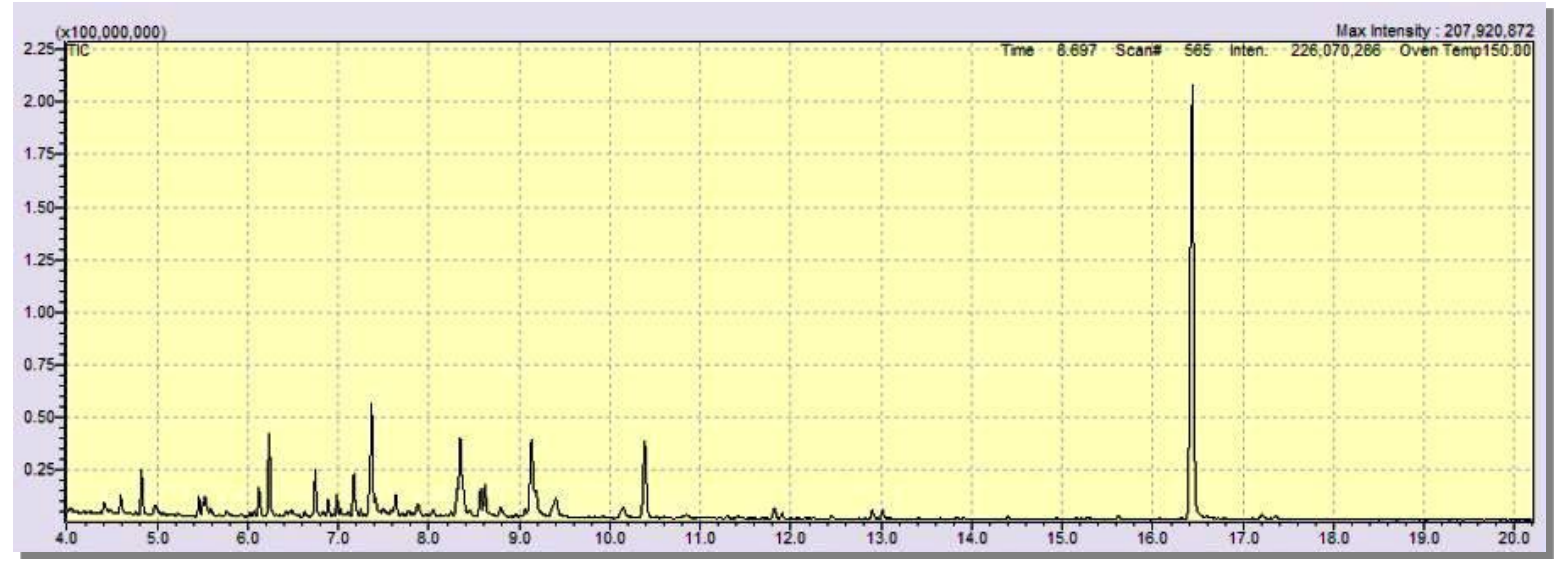

FIGURA 71 - Cromatograma da análise qualitativa do bio-óleo em repouso por mais de 100 dias, obtido por GC/MS no modo SCAN. 


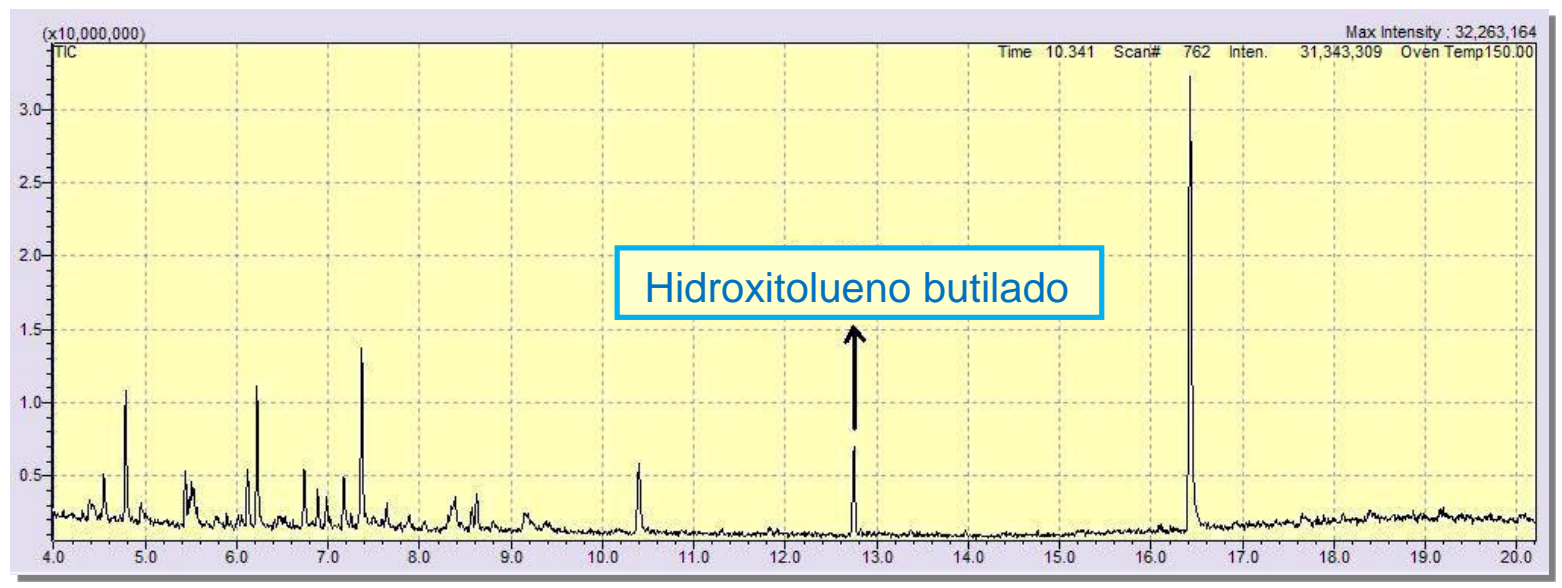

FIGURA 72 - Cromatograma da análise qualitativa do bio-óleo em repouso por menos de 100 dias, obtido por GC/MS no modo SCAN.

Segundo a literatura, o bio-óleo proveniente da pirólise da biomassa, quando deixado em repouso por mais de 100 dias, melhora as condições do produto, particularmente na agricultura, podendo ser utilizado tanto como adubo e fortificante foliar, como também em alternativa aos defensivos químicos convencionais no controle de pragas ${ }^{[125,126]}$.

Pode-se observar que não houve praticamente nenhuma alteração entre os cromatogramas, exceto pelo composto hidroxitolueno butilado, que aparece no bio-óleo em período de tempo de repouso inferior a 100 dias.

$\mathrm{Na}$ TAB.18, apresentam-se os principais compostos químicos do bio-óleo obtido no processo de pirólise da palha do café determinados por GC/MS com os respectivos tempos de retenção, nomes, fórmula química, massa molecular e CAS number. 
TABELA 18 - Principais compostos químicos presentes no bio-óleo obtido no processo de pirólise da palha do café determinados por GC/MS

\begin{tabular}{|c|c|c|c|c|}
\hline T.R.(min) & Composto & $\begin{array}{l}\text { Fórmula } \\
\text { Química }\end{array}$ & M.M. & $\begin{array}{c}\text { CAS } \\
\text { number }\end{array}$ \\
\hline 4,8 & 2-Furanometanol & $\mathrm{C}_{5} \mathrm{H}_{6} \mathrm{O}_{2}$ & 98 & $98-00-0$ \\
\hline 6,18 & $\begin{array}{l}\text { Ácido 4- } \\
\text { Hidroxibenzenossulfônico }\end{array}$ & $\mathrm{C}_{6} \mathrm{H}_{6} \mathrm{O}_{4} \mathrm{~S}$ & 174 & $98-67-9$ \\
\hline 6,23 & Fenol & $\mathrm{C}_{6} \mathrm{H}_{6} \mathrm{O}$ & 94 & $108-95-2$ \\
\hline 6,68 & 3-Metil1,2-Ciclopentanodieno & $\mathrm{C}_{6} \mathrm{H}_{8} \mathrm{O}_{2}$ & 112 & $765-70-8$ \\
\hline 7,18 & 3-Metilfenol (m-Cresol) & $\mathrm{C}_{7} \mathrm{H}_{8} \mathrm{O}$ & 108 & $108-39-4$ \\
\hline 7,4 & Mequinol & $\mathrm{C}_{7} \mathrm{H}_{8} \mathrm{O}_{2}$ & 124 & $150-76-5$ \\
\hline 8,26 & 2-Metilfenol (o-Cresol) & $\mathrm{C}_{7} \mathrm{H}_{8} \mathrm{O}$ & 108 & $95-48-7$ \\
\hline 8,61 & $\begin{array}{l}\text { 1,4: 3,6-Dianidro- } \alpha \\
\text { D-glucopiranose }\end{array}$ & $\mathrm{C}_{6} \mathrm{H}_{8} \mathrm{O}_{4}$ & 144 & $4451-30-3$ \\
\hline 9,18 & Hidroquinona & $\mathrm{C}_{6} \mathrm{H}_{6} \mathrm{O}_{2}$ & 110 & $123-31-9$ \\
\hline 10,38 & 2,6-Dimetoxifenol & $\mathrm{C}_{8} \mathrm{H}_{10} \mathrm{O}_{3}$ & 154 & $91-10-1$ \\
\hline 12,78 & $\begin{array}{l}\text { 4-Metilfenol ou Hidroxitolueno } \\
\text { butilado ( } p \text {-Cresol) }\end{array}$ & $\mathrm{C}_{15} \mathrm{H}_{24} \mathrm{O}$ & 220 & $128-37-0$ \\
\hline 16,42 & 1,3,7 trimetilxantina (Cafeína) & $\mathrm{C}_{8} \mathrm{H}_{10} \mathrm{~N}_{4} \mathrm{O}_{2}$ & 194 & $58-08-2$ \\
\hline
\end{tabular}

Na FIG.73 tem-se as fórmulas estruturais dos principais compostos do bio-óleo obtido no processo de pirólise da palha do café determinados por CG/MS. 


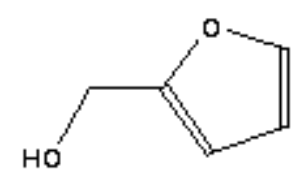

2-Furanometanol

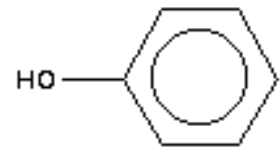

Fenol

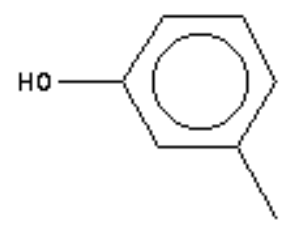

3-Metilfenol

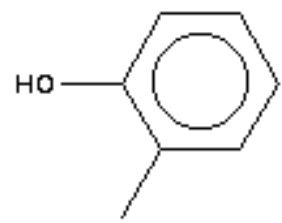

2-Metilfenol

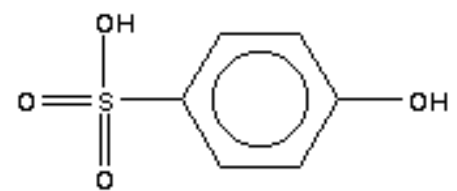

Ácido 4-Hidroxibenzenossulfônico

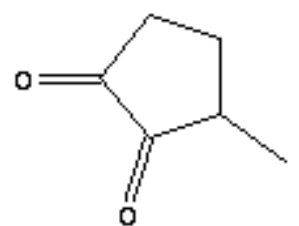

3-Metil1,2-Ciclopentanodieno<smiles>COc1ccc(O)cc1</smiles>

Mequinol

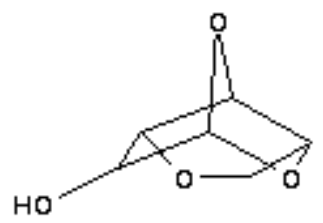

1,4:3,6 Dianidro-a-d-glucopiranose 


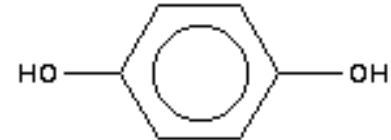

Hidroquinona

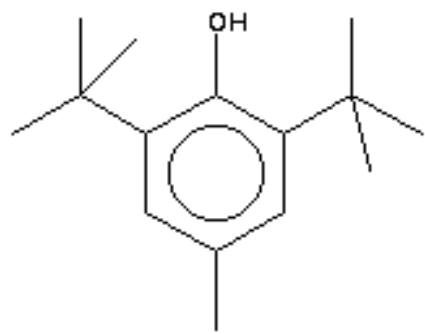

4-Metilfenol<smiles>COc1cccc(OC)c1O</smiles>

2,6-Dimetoxifenol<smiles>Cn1c(=O)c2c(ncn2C)n(C)c1=O</smiles>

1,3,7 Trimetilxantina

FIGURA 73 - Fórmulas estruturais dos principais compostos químicos presentes no bio-óleo obtido da pirólise da palha do café determinados por GC/MS.

O que visualmente pôde-se observar é que quanto maior o tempo de repouso, mais homogêneo o bio-óleo vai se tornando, como mostra a FIG.74. 


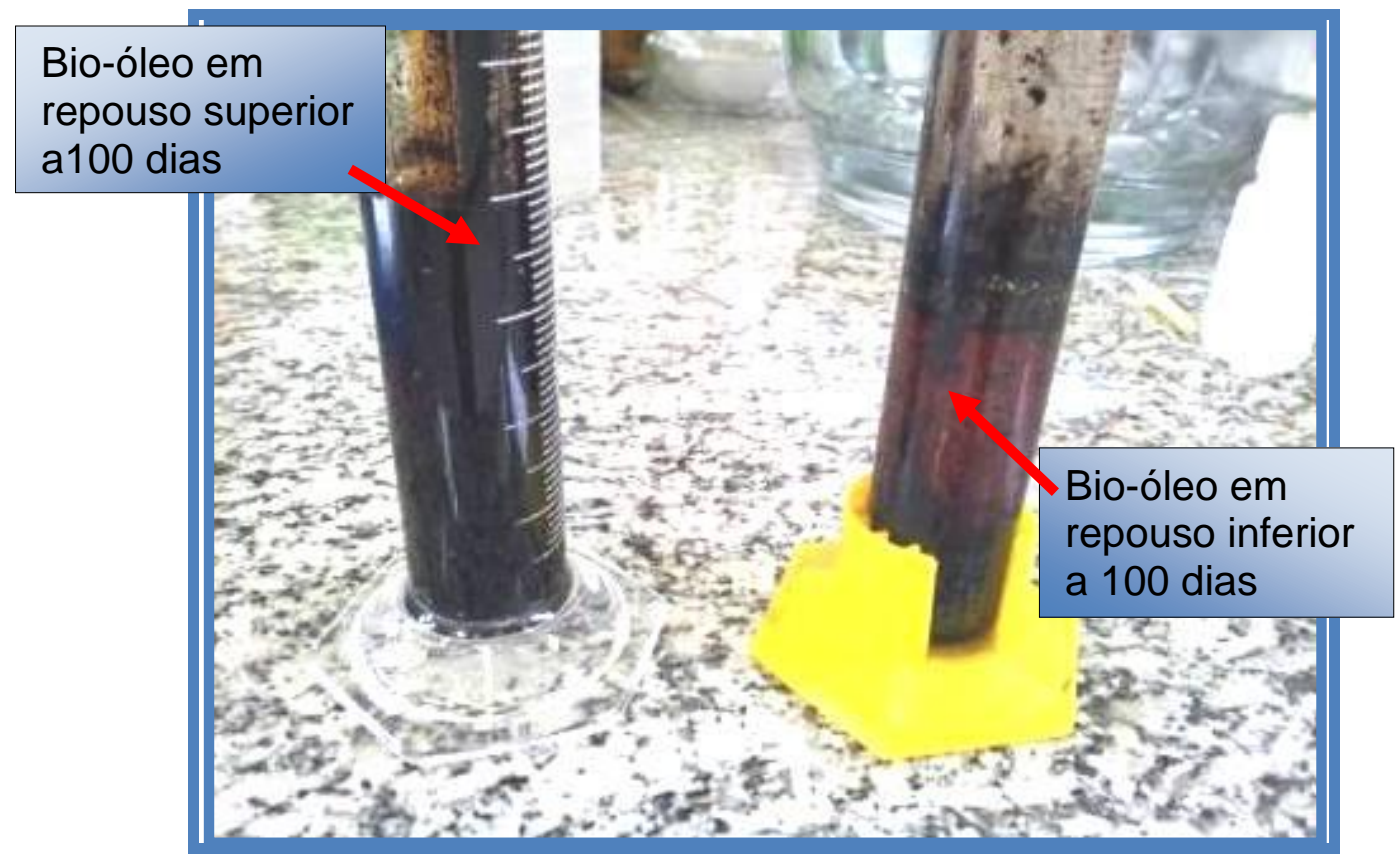

FIGURA 74 - Bio-óleo com tempo de repouso superior e inferior a 100 dias.

\subsubsection{Bio-óleo esterificado}

Na FIG.75 tem-se o cromatograma do bio-óleo esterificado, processo utilizado na fabricação de biodiesel.

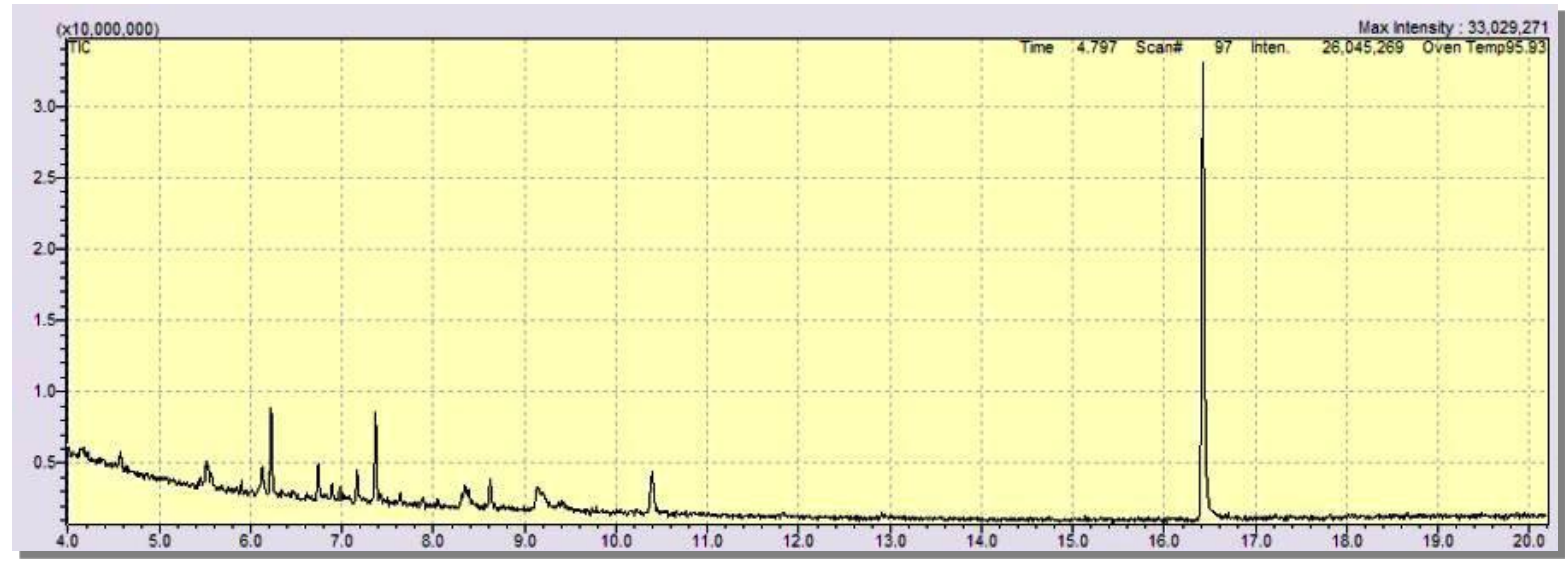

FIGURA 75 - Cromatograma da análise qualitativa do bio-óleo esterificado, obtido por GC/MS no modo SCAN. 
$\mathrm{Na}$ TAB.19, apresentam-se os principais compostos químicos presentes no bio-óleo esterificado obtido pelo processo de pirólise da palha do café determinados por GC/MS com os respectivos tempos de retenção, nomes, fórmula química, peso molecular e CAS number.

TABELA 19 - Principais compostos químicos do bio-óleo esterificado obtido pelo processo de pirólise da palha do café determinados por GC/MS

\begin{tabular}{ccccc}
\hline T.R.(min) & Composto & $\begin{array}{c}\text { Fórmula } \\
\text { Química }\end{array}$ & M.M. & $\begin{array}{c}\text { CAS } \\
\text { number }\end{array}$ \\
\hline 6,18 & $\begin{array}{c}\text { Ácido 4- } \\
\text { Hidroxibenzenossulfônico }\end{array}$ & $\mathrm{C}_{6} \mathrm{H}_{6} \mathrm{O}_{4} \mathrm{~S}$ & 174 & $98-67-9$ \\
6,23 & Fenol & $\mathrm{C}_{6} \mathrm{H}_{6} \mathrm{O}$ & 94 & $108-95-2$ \\
6,68 & 3-Metil1,2-Ciclopentanodieno & $\mathrm{C}_{6} \mathrm{H}_{8} \mathrm{O}_{2}$ & 112 & $765-70-8$ \\
7,18 & 3-Metilfenol (m-Cresol) & $\mathrm{C}_{7} \mathrm{H}_{8} \mathrm{O}$ & 108 & $108-39-4$ \\
7,4 & Mequinol & $\mathrm{C}_{7} \mathrm{H}_{8} \mathrm{O}_{2}$ & 124 & $150-76-5$ \\
8,61 & 1,4: 3,6-Dianidro- $\alpha$ & $\mathrm{C}_{6} \mathrm{H}_{8} \mathrm{O}_{4}$ & 144 & $4451-30-3$ \\
& d-glucopiranose & & & \\
10,38 & 2,6-Dimetoxifenol & $\mathrm{C}_{8} \mathrm{H}_{10} \mathrm{O}_{3}$ & 154 & $91-10-1$ \\
16,42 & $1,3,7$ Trimetilxantina(Cafeína) & $\mathrm{C}_{8} \mathrm{H}_{10} \mathrm{~N}_{4} \mathrm{O}_{2}$ & 194 & $58-08-2$ \\
\hline
\end{tabular}

Nas condições de análise da esterificação do bio-óleo não se encontraram compostos orgânicos que o classificassem como um bom combustível.

$\mathrm{Na}$ FIG.76 tem-se ilustradas as fórmulas estruturais dos compostos encontrados nas medidas por GC/MS dos principais compostos químicos do bio-óleo esterificado obtido do processo de pirólise da palha do café. 
<smiles>O=S(=O)(O)c1ccc(O)cc1</smiles>

Ácido benzenosulfônico<smiles>CC1CCC(=O)C1=O</smiles>

3-Metil1,2-Ciclopentanodieno<smiles>COc1ccc(O)cc1</smiles>

Mequinol<smiles>COc1cccc(OC)c1O</smiles>

2,6-Dimetoxifenol<smiles>Oc1ccccc1</smiles>

Fenol

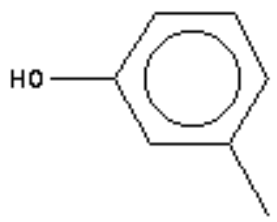

3-Hidroxitolueno

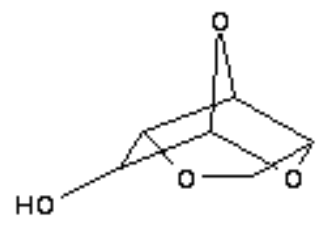

1,4:3,6 Dianidro- $\alpha-d-g l u c o p i r a n o s e$<smiles>Cn1c(=O)c2c(ncn2C)n(C)c1=O</smiles>

1,3,7 Trimetilxantina

FIGURA 76 - Fórmulas estruturais dos principais compostos químicos presentes no bio-óleo esterificado obtido da pirólise da palha do café determinados por GC/MS. 


\subsubsection{Análise do hidrogênio por cromatografia a gás}

Durante o processo de pirólise obteve-se, no início, a eliminação da umidade contida no material, seguido da condensação dos voláteis e consequente produção do bio-óleo. O hidrogênio foi medido por cromatografia a gás, retirando-se alíquotas de $10 \mu \mathrm{L}$, injetando-as, em tempo real, no cromatógrafo.

Nas FIG. 77, 78, 79, 80, 81 e 82, pode-se observar os cromatogramas com os melhores resultados da obtenção de hidrogênio via pirólise da palha do café, quando processados $54 \mathrm{~g}$, a uma pressão de alimentação de $5,5 \mathrm{kgf} / \mathrm{cm}^{2}$.

Os picos de hidrogênio foram apresentados por ordem crescente, no que tange ao percentual de evolução do hidrogênio como produto gasoso do processo de pirólise da palha do café.

Tal evolução tem uma relação estreita com os valores de temperatura de operação, portanto, além dos percentuais de hidrogênio, foram citadas as temperaturas em que as amostras foram retiradas quando do processo de pirólise da palha do café.

Muito embora algumas das escalas dos cromatogramas sejam diferentes entre si, isso não interferiu nos cálculos, uma vez que o hidrogênio tem um intervalo de tempo de retenção (T.R.) pré-determinado entre 2,8 a 2,9 min, bem como o padrão comparativo utilizado para obtenção dos cromatogramas foi sempre o mesmo.

Vale lembrar, que o tamanho do pico não indica uma maior ou menor quantidade de hidrogênio na amostra. $O$ cálculo foi realizado a partir da área equivalente a 5,000 min, considerada como $100 \%$, referente a um gás hidrogênio padrão.

Na FIG.77 observa-se um cromatograma correspondente à análise do hidrogênio na batelada 8 (amostra 1). 


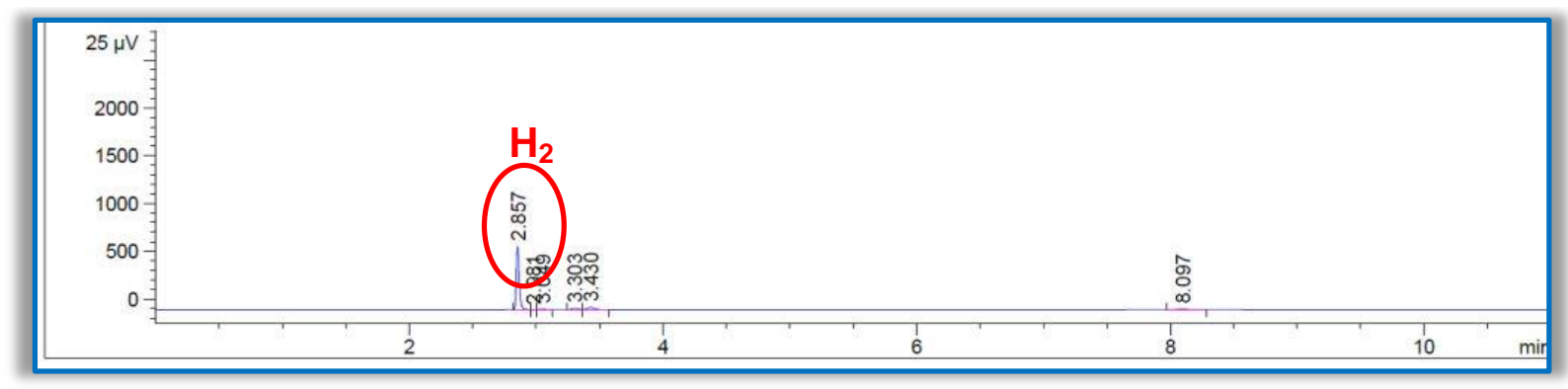

FIGURA 77 - Cromatograma do hidrogênio obtido no processo da batelada 8 (amostra 1).

A temperatura de operação observada quando da retirada da amostra foi de $693{ }^{\circ} \mathrm{C}$. O cálculo foi feito levando-se em consideração a área obtida no tempo de retenção do intervalo correspondente ao hidrogênio, T.R. 2,857 min. Calculou-se um rendimento de $21 \%$ de hidrogênio.

No cromatograma da FIG.78 pode-se observar a obtenção de 22,3\% de hidrogênio, correspondente à batelada 8 (amostra 2).

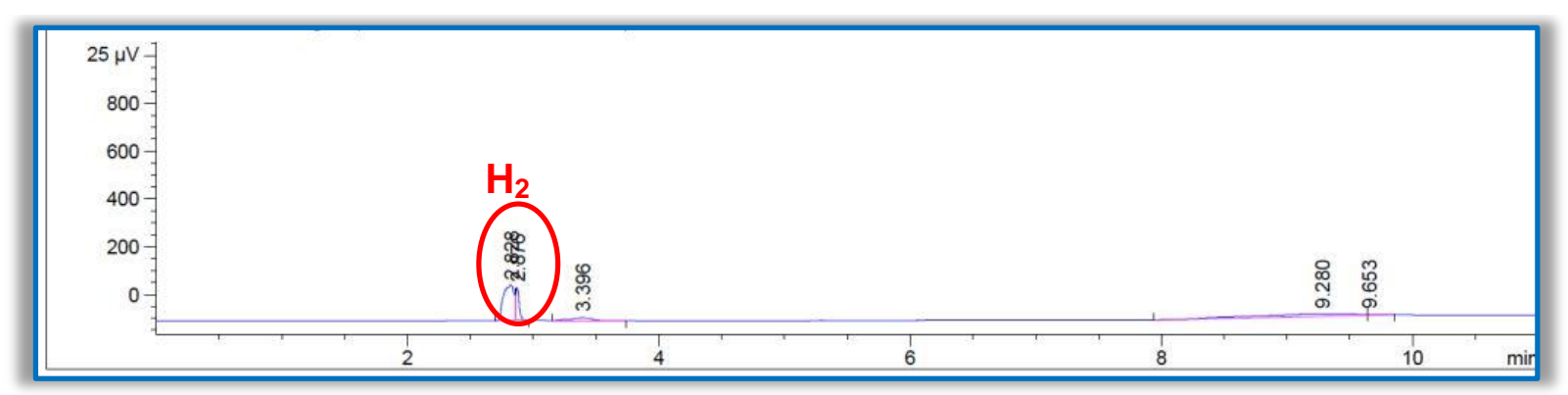

FIGURA 78- Cromatograma do hidrogênio obtido no processo da batelada 8 (amostra 2).

A temperatura de operação observada quando da retirada da amostra foi de $695{ }^{\circ} \mathrm{C}$. Neste caso, foi calculado o percentual da amostra fazendo-se a somatória das áreas dos dois picos que aparecem no intervalo de retenção do hidrogênio, T.R. 2,828 e 2,876 min.

$\mathrm{Na}$ FIG.79 observa-se um cromatograma apresentando $24,3 \%$ de hidrogênio, correspondente à batelada 9 (amostra 1). 


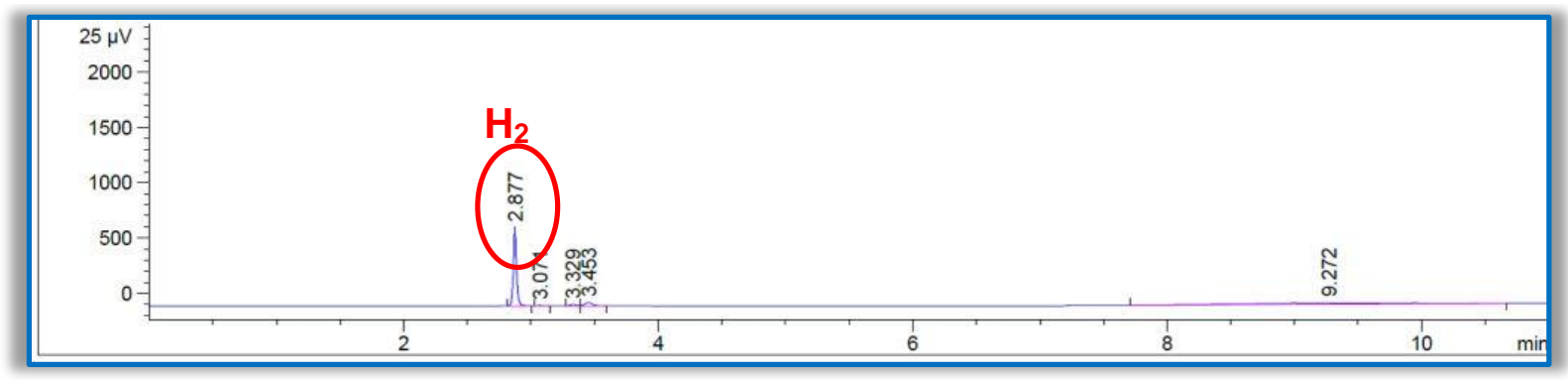

FIGURA 79 - Cromatograma do hidrogênio obtido no processo da batelada 9 (amostra 1).

A temperatura de operação observada quando da retirada da amostra foi de $692{ }^{\circ} \mathrm{C}$. O cálculo foi realizado levando-se em consideração a área obtida no tempo de retenção do intervalo correspondente ao hidrogênio, T.R. 2,877 min.

Na FIG.80 o cromatograma temos a produção de $31,4 \%$ de hidrogênio, correspondente à batelada 9 (amostra 2).

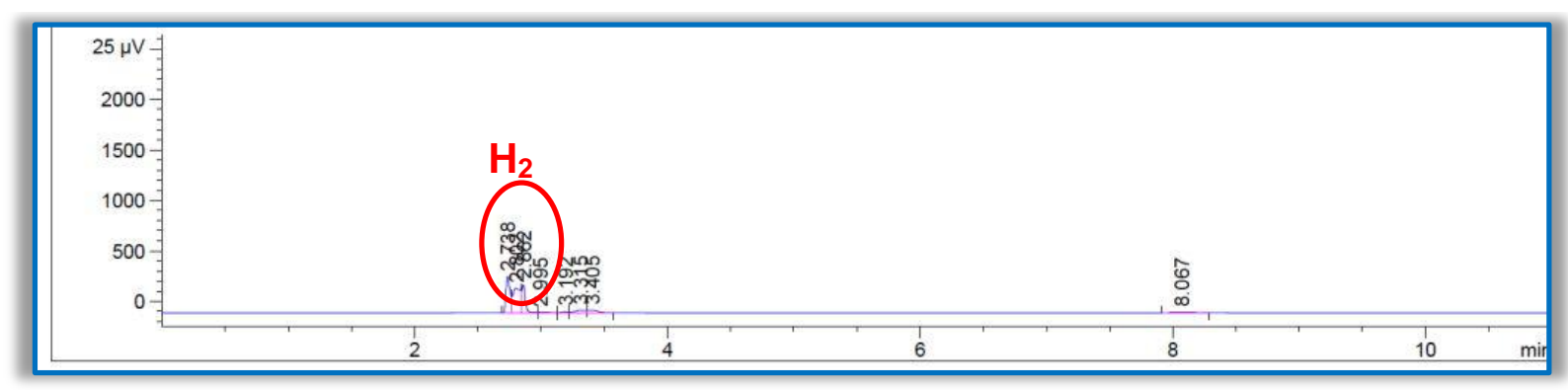

FIGURA 80 - Cromatograma do hidrogênio obtido no processo da batelada 9 (amostra 2).

A temperatura de operação observada quando da retirada da amostra foi de $699{ }^{\circ} \mathrm{C}$. Neste caso, foi calculado o percentual da amostra fazendo-se a somatória das áreas dos dois picos que aparecem no intervalo de retenção do hidrogênio, T.R. 2,802 e 2,862 min.

Na FIG. 81 pode-se observar um cromatograma da obtenção de $41,2 \%$ de hidrogênio, correpondente à batelada 13 (amostra 1). 


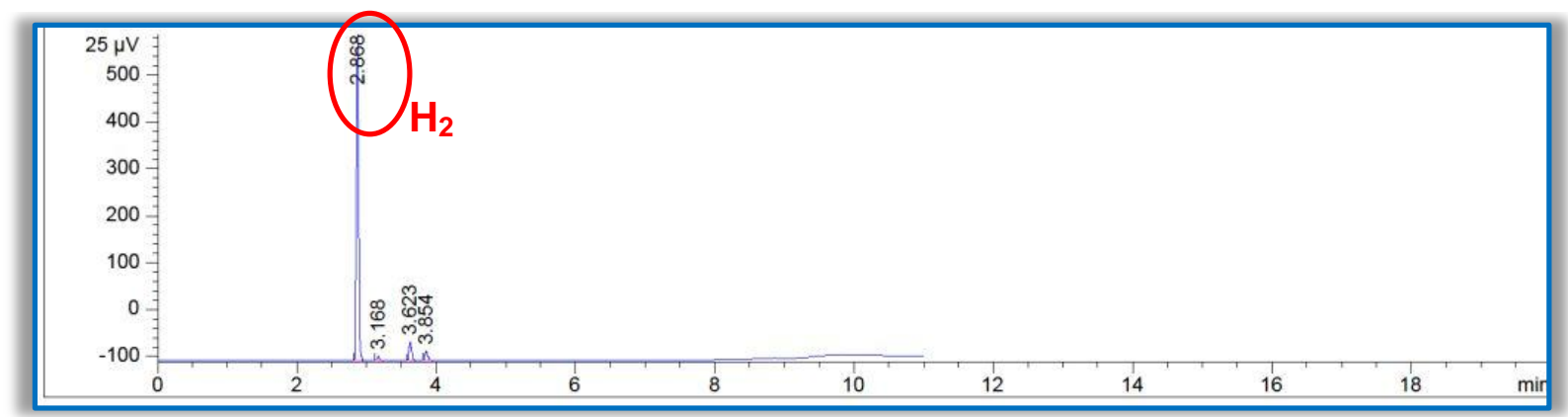

FIGURA 81 - Cromatograma do hidrogênio obtido no processo da batelada 13 (amostra 1).

A temperatura de operação observada quando da retirada da amostra foi de $706{ }^{\circ} \mathrm{C}$. O cálculo foi realizado levando-se em consideração a área obtida no tempo de retenção do intervalo correspondente ao hidrogênio, T.R. 2,868 min.

O cromatograma da FIG.82 mostra a produção de $49,8 \%$ de hidrogênio, maior porcentagem obtida nos experimentos realizados, correspondente á batelada 13 (amostra 2).

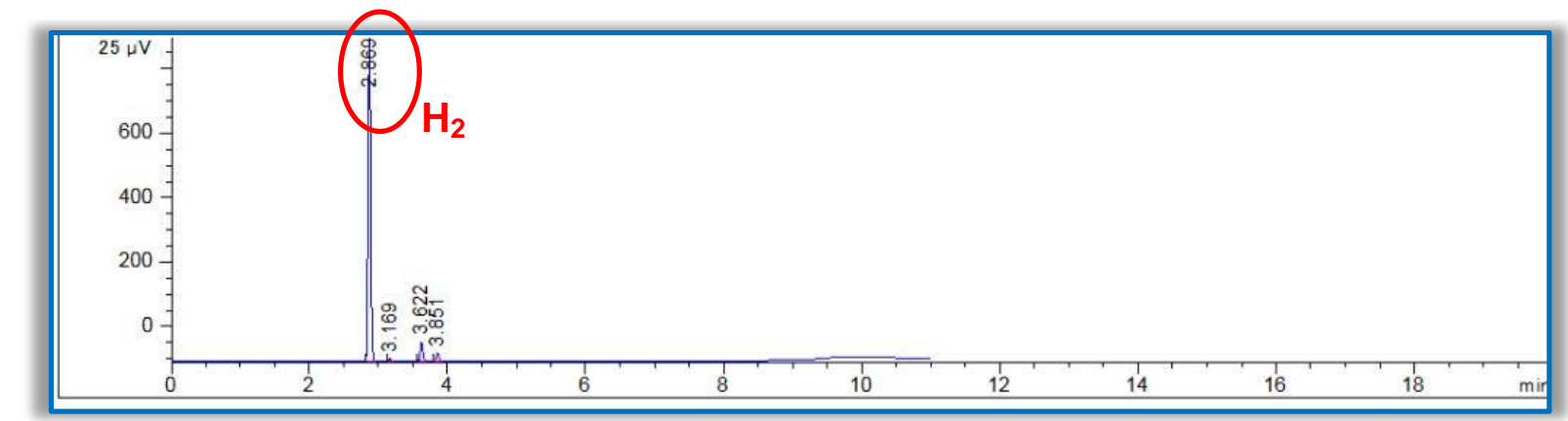

FIGURA 82 - Cromatograma do hidrogênio obtido no processo da batelada 13 (amostra 2).

A temperatura de operação observada quando da retirada da amostra foi de $708{ }^{\circ} \mathrm{C}$. O cálculo foi feito levando-se em consideração a área obtida no tempo de retenção do intervalo correspondente ao hidrogênio, T.R. 2,869. 
Na FIG. 83, está ilustrada a evolução do teor de hidrogênio em função da temperatura no processo de pirólise da palha do café, nas bateladas referenciadas acima.

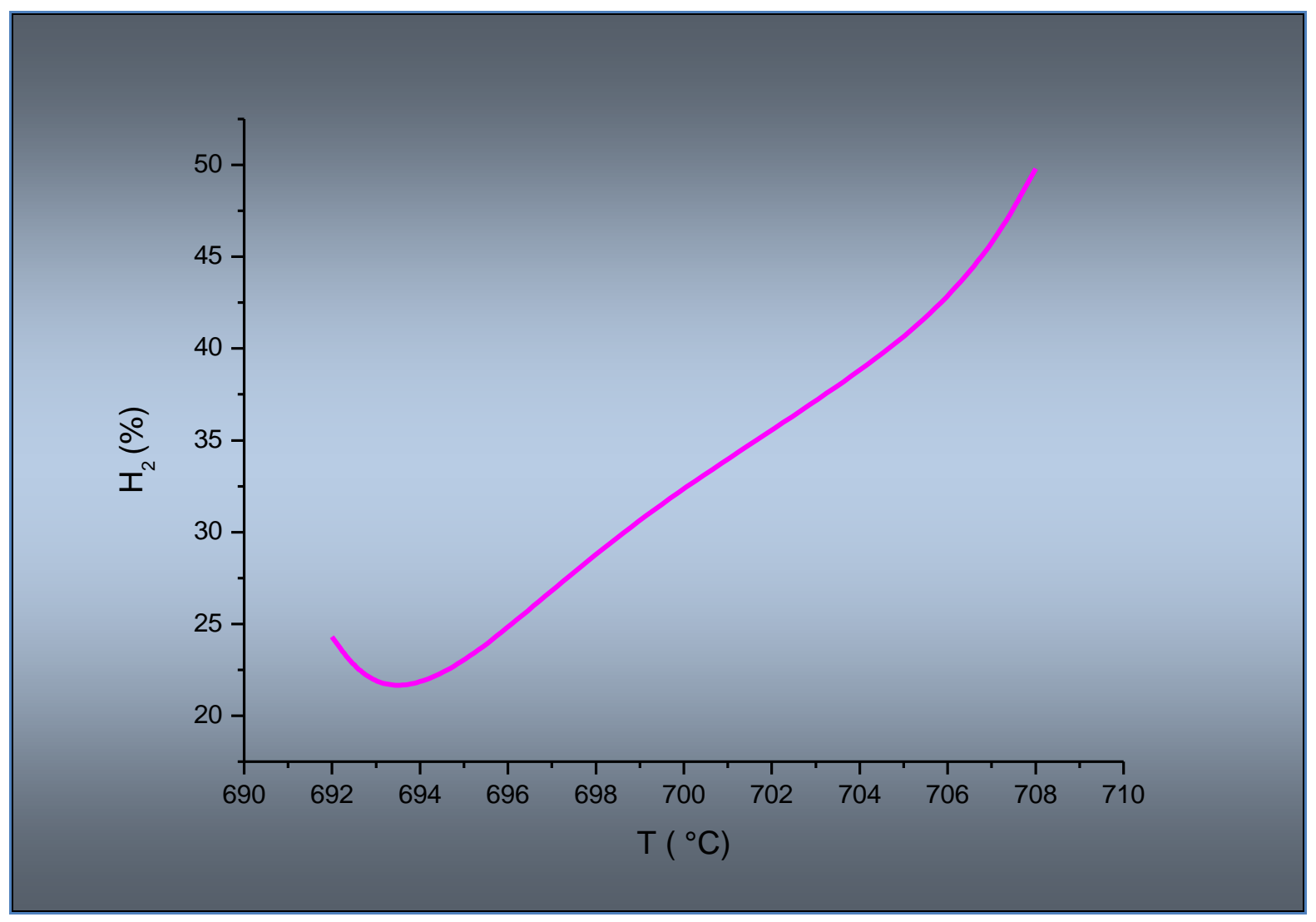

FIGURA 83 - Evolução do teor de hidrogênio em função da temperatura no processo de pirólise da palha do café.

Pode-se observar a partir dos dados das análises de cromatografia a gás, que conforme a temperatura vai se aproximando dos $700{ }^{\circ} \mathrm{C}$, maior é o teor de obtenção de hidrogênio contido na amostra, corroborando os dados citados na literatura ${ }^{[127]}$. 


\section{CONSIDERAÇÕES FINAIS}

A partir dos estudos realizados com a pirólise da palha do café, podese considerar que:

- O poder calorífico superior (PCS) da palha do café calculado em 23,64 MJ/kg, quando comparado ao de outras biomassas, como, por exemplo, o bagaço da cana de açúcar que tem um PCS $=17,33 \mathrm{MJ} / \mathrm{kg}$ se destaca, indicando ser um bom combustível, não só para gerar calor em fornalhas, o que já acontece em algumas fazendas, onde a palha do café substitui ou agrega valor à lenha nas fornalhas de secagem do grão, como também para gerar energia elétrica em pequenas comunidades, onde a produção de resíduo seja significativa.

- O percentual de 5,5 \pm 0,1 de teor de hidrogênio em base seca, obtido por de análise elementar para a palha do café, comparado ao teor de outras biomassas como, por exemplo, o bagaço de cana com 5,35 \% de hidrogênio em sua composição química elementar, indica que pode ser utilizado na obtenção do hidrogênio em processo de pirólise.

- As curvas TG/DTG possibilitaram inferir sobre a quantidade de água presente nas amostras, assim como, discutir sobre a massa residual. As curvas DSC confirmaram os dados de TG para a desidratação térmica do material em estudo. Pode-se, a partir dessas curvas, concluir que a decomposição térmica do material é exotérmica, não importando se este faz parte da divisão interna ou externa da palha de café, tornando-a viável para fins energéticos.

- As curvas DSC determinaram um alto valor energético da mistura das palhas interna e externa do café com $\Delta \mathrm{H}=249,0 \mathrm{~J} \mathrm{~g}^{-1}$, corroborando os dados de TG para a desidratação térmica do material em estudo. Pode-se, a partir dessas 
curvas, concluir que a decomposição térmica do material é exotérmica, tornandoo viável para fins energéticos.

- Observou-se também, a partir das análises GC/MS, que não há diferença considerável nas composições da palha do café in natura e da palha de café seca, concluindo-se que há possibilidade da utilização tanto de uma quanto de outra no processo de pirólise, apenas atentando para o fato de que a utilização da palha do café in natura seria menos dispendiosa, quando da implantação de uma usina piloto.

- Os dados da análise elementar das cinzas corroborou os resultados das cromatografias gasosas, uma vez que o menor teor de hidrogênio contido nas cinzas correspondeu ao melhor teor de gás hidrogênio obtido na pirólise.

- A melhor pressão de alimentação que se observou para a obtenção de hidrogênio pela pirólise da palha do café, foi a de $5,5 \mathrm{kgf} / \mathrm{cm}^{2}$, corroborando os dados obtidos na análise elementar das cinzas e cromatografia a gás, concluindose que o processo de pirólise a essa pressão é bem mais eficaz quando se pretende obter maior rendimento de produto gasoso.

- Quanto maior a taxa de aquecimento e maior a temperatura de operação atingida, melhor o rendimento do hidrogênio obtido no processo, desde que a vazão de gás de alimentação do processo seja controlada para que não haja vazamentos ou escapes de gases pelo flange do reator, inferindo em prejuízo para o processo.

- Neste trabalho atingiram-se taxas de aquecimento na ordem de $40{ }^{0} \mathrm{C} / \mathrm{min}$, porém houve escape de gases nas conexões, determinando que para o processo de pirólise da palha do café, $20{ }^{0} \mathrm{C} / \mathrm{min}$ é uma taxa bastante satisfatória no que diz respeito ao teor de hidrogênio obtido no produto final, conforme resultado da batelada 13, que alcançou a essa taxa, valores próximos a $50 \%$ da amostra retirada de $10 \mu \mathrm{L}$ de produto gasoso. 
- Com o estudo da influência da temperatura no processo de pirólise, podem-se determinar os pontos de vaporização e condensação da água da amostra, bem como o da obtenção do bio-óleo, confirmando os valores das temperaturas correspondentes nas análises térmicas.

- O rendimento gravimétrico dos sólidos e líquidos do processo inferiram na determinação da melhor pressão de operação a ser utilizada, dependendo do produto desejado. Concluiu-se que quando o objetivo é a obtenção de hidrogênio, os resultados são melhores quando a pirólise é feita em alta pressão, ou seja, a $5,5 \mathrm{kgf} / \mathrm{cm}^{2}$.

- Os dados da análise elementar das cinzas provenientes da pirólise da palha do café corroboraram os rendimentos gravimétricos, quando se compara os resultados de teores de hidrogênio. Para a pressão menor $(4,8 \mathrm{kgf} / \mathrm{cm})$, obteve-se um maior percentual de hidrogênio na análise elementar, e maior rendimento da fase líquida, enquanto que, quando se utiliza uma pressão maior $(5,5 \mathrm{kgf} / \mathrm{cm})$, o rendimento gravimétrico da fase líquida é menor, o percentual de hidrogênio é menor, confirmando com o maior o teor de hidrogênio na fase gasosa.

- O bio-óleo quando deixado em repouso, vai ficando cada vez mais homogêneo, mas não apresenta compostos muito diferenciados em sua constituição, quando comparado com o que não ficou em repouso.

- O bio-óleo da palha do café é de fácil esterificação. Ele pode ser utilizado em indústrias químicas nas suas mais diversas ramificações.

- A evolução do teor de hidrogênio é maior quanto mais a temperatura se aproxima dos $700{ }^{\circ} \mathrm{C}$, obtendo-se as melhores taxas desse elemento, quando esta temperatura é ultrapassada, conforme os resultados obtidos por cromatografia a gás do produto gasoso da pirólise da palha do café.

- A mistura gasosa obtida no processo de pirólise da palha do café, contém além de hidrogênio, outros gases, como por exemplo o monóxido de carbono. Assim sendo esse material pode ser utilizado em uma célula a 
combustível de altas temperaturas, a SOFC (solid oxide fuel cell). Para a utilização em uma célula a combustível tipo PEM (proton exchange membrane), há necessidade de se purificar o hidrogênio, por meio de técnicas como reatores de membrana purificadora à base de paládio. 


\section{REFERÊNCIAS BIBLIOGRÁFICAS}

[1] BARRETO, E.J.F, et al. Pequenos Aproveitamentos Hidroelétricos Soluções Energéticas para a Amazônia, 1.ed., Brasília, Ministério de Minas e Energia, 2008. Disponível em: <http://luzparatodos.mme.gov.br>. Acesso em: Mar 2012.

[2] QUEIROZ, R. Os combustíveis fósseis e o aquecimento global no intrincado jogo da política energética. Infopetro, 08/08/2011. Disponível em: $<$ http://infopetro.wordpress.com>. Acesso em: Jun 2012.

[3] SHINNAR, R.; CITRO, F. Decarbonization: Achieving near-total energy independence and near-total elimination of greenhouse emissions with available technologies. Technology in Society, n.30, p. 1-16, 2008.

[4] EDMONDS, I.; SMITH, G. Surface reflectance and conversion efficiency dependence of technologies for mitigating global warming. Renewable Energy, n.36, p.1343-1351, 2011.

[5] GOLDEMBERG, J.; LUCON, O. Energias renováveis: um futuro sustentável. Revista USP, São Paulo, n.72, p. 6-15, fev. 2007.

[6] BARROS, R.W. ARADAS, M.E.C.; COBAS, V.R.M.; LORA, E.E.S. Uso de biomassa para acionamento de motores stirling. In: ENCONTRO DE ENERGIA NO MEIO RURAL E GERAÇÃO DISTRIBUÍDA, $5^{0}$ AGRENER GD, 19-21 Out, 2004, Campinas, SP. Proceedings...UNICAMP, 2004. 1CDROM.

[7] TOMASQUIM, M.T., Alternativas energéticas sustentáveis no Brasil. 1.ed. Rio de Janeiro, R.J.: Relume Dumará, 2004.

[8] VASCONCELLOS, G.F. Biomassa - A eterna energia do futuro. 1.ed. São Paulo, S.P.: SENAC, 2002.

[9] CONAB, Companhia Nacional de Abastecimento, Levantamento de Safra. Disponível em: <http://www.conab.gov.br>. Acesso em: Mar 2012.

[10] VENTURIM, J.B. Gestão de residuos orgánicos produzidos no meio rural: 0 caso do beneficiamento do café. 2002. Tese (Doutorado) Universidade Federal de santa Catarina, Florianópolis. 
[11] Pé de café pode ser usado para reflorestar, diz novo Código. Folha.com, São Paulo, 29 maio 2012. Disponível em: <http://www1.folha.uol.com.br >. Acesso em: Maio 2012.

[12] FIGUEIREDO, F.A.B. et al. Pyrolysis and gasification of cashew nut (Anacardium Occidentale L.) Shell: Liquid, solid and gas products. In: 19th International Congress of mechanical Engineering (COBEM). November 5-9, 2008, Brasília, DF. Anais eletrônicos... Brasília.

[13] SÁNCHEZ, C.G. et al. Tecnologia da gaseificação de biomassa. 1.ed. Campinas, S.P.: Átomo, 2010.

[14] RIFKIN, J. A Economia do hidrogênio. 1.ed. São Paulo, S.P.: M.Books do Brasil, 2003.

[15] HOFFMANN, P. Tomorrow's energy: hydrogen, fuel cells, and the prospects for a cleaner planet. Rev. And expanded ed. Cambridge, MA.: The MIT Press, 2012.

[16] BERNARDI, C.V. Perspectivas da geração de créditos de carbono com base na obtenção de um fertilizante - aproveitamento de resíduos de biomassa da agricultura brasileira. 2009. Tese (Doutorado) - Instituto de Pesquisas Energéticas e Nucleares, São Paulo.

[17] BP Statistical Review of World Energy. Coal, production and consumption. Jun 2011.2 Disponível em: $<$ http://www.bp.com/statisticalreview>. Acesso em: Jun 2012.

[18] Um futuro com energia sustentável: iluminando o caminho, São Paulo, FAPESP; Amsterdam, Inter Academy Council ; Rio de Janeiro, Academia Brasileira de Ciências, 2010.

[19] INTERGOVERNMENTAL PANEL ON CLIMATE CHANGE. Good practice guidance and uncertainly management in national greenhouse gas inventories. IPCC, 2007.

[20] PENNER, J.E. Avaliation and the global atmosphere. Cambridge University Press. Cambridge, UK. Databases to IPCC, 1999.

[21] INTERGOVERNMENTAL PANEL ON CLIMATE CHANGE. Revised 2006 IPCC guidelines for national greenhouse gas inventories. Paris: United Nationas Environment Programme, Organization for Econoic CoOperation and Development, International Energy Agency. IPCC/UNEP/OECD/IEA, 1997.

[22] HOFMANN, D.J. ET AL. Tracking climate forcing: The annual greenhouse gas index, EOS, Transactions, American geophysical. Union, 87, Nov.16, 2006, p.509-511. 
[23] SANA, H.S.P. Aterros sanitários e o mercado de créditos de carbono: Análise de viabilidade económica para empreendimentos sustentáveis em municipios no interior de São Paulo. São Paulo: IBMEC, 2006.

[24] MINISTÉRIO DAS RELAÇÕES EXTERIORES. CQNUMC, Convenção quadro da Nações Unidas sobre mudança do clima. Tradução conjunta, MCT, MRT. Rio de Janeiro: FGV, 2002.

[25] ENVIRONMENTAL PROTECTION AGENCY. Inventory of U.S. greenhouse gas emissions and sinks: 1990-2007. U.S. Washington, DC. April 2009. Disponível em: <http://epa.gov/climatechange/index.html>. Acesso em: Mai 2012.

[26] METZ, B.; DAVIDSON, O.R.; BOSH, P.R.; DAVE, R. MEYER, L.A. Climate change 2007: Mitigation of Climate change. Contribuition of working group III to the fourth assessment report os the intergovernamental panel on Climate change, 2007 (IPCC). New York: Cambridge University Press.

[27] RAMANATHAN, V. et al. Warming trends in Asia amplified by brown cloud solar absorption. Nature, n.448, p.575-578, August 2007.

[28] UNITED NATIONS. Framework Convention on Climate Change. Joint implementation (JI). Disponível em: $<$ http://unfccc.int/kyoto protocol/mechanisms/joint implementation >. Acesso em: Maio 2012.

[29] INSTITUTO CARBONO BRASIL. Implementação conjunta - Mercado de Carbono/Protocolo de Quioto. Disponível em: <http://www.institutocarbonobrasil.org.br>. Acesso em: Maio 2012.

[30] BM\&FBOVESPA. Mercado de carbono. Disponível em: <http://www.bmfbovespa.com.br/pt-br/mercados/mercado-de-carbono>. Acesso em Jun 2012.

[31] INTERGOVERNMENTAL PANEL ON CLIMATE CHANGE. IPCC Fourth Assessment Report: Climate Change 2007. Disponível em: <http://www.ipcc.ch/publications and data/ar4/wg1/en/tssts-2-5.html>.

Acesso em Jun 2012.

[32] TOLMASQUIM, M.T e col. Fontes Renováveis de Energia no Brasil. 1.ed. Rio de Janeiro, R.J.: Interciência, 2003.

[33] BINAS, F. Cenário econômico mundial favorece onda de consolidação no setor de energia renovável. Estudo da Ernst\&Young coloca Brasil como

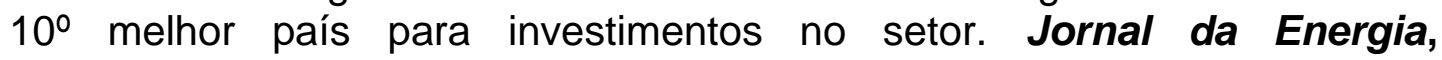
27/04/2012. Disponível em: <http://www.jornaldaenergia.com.br >. Acesso em: Maio 2012. 
[34] SARIEGO, J.C. Educação ambiental: as ameaças ao planeta azul. 1 ed., São Paulo: Scipione, 2004.

[35] MACEDO, I.C. Estado da arte e tendências tecnológicas para energia. Brasília, DF: Centro de Gestão de Estudos estratégicos, 2002.

[36] WRIGHT, L. Worldwide commercial development of bioenergy with a focus on energy crop-based projects. Biomass \& Bioenergy, n.30 (8-9), p. 706-714, August-September 2006.

[37] ANEEL - Agência nacional de Energia Elétrica. Atlas de Energia Elétrica do Brasil, 3 ed., p. 63-73, Brasília, 2008.

[38] SILVA, M.J.M.; RUGGERO, P.A. Efeitos da Utilização da Energia da Biomassa sobre 0 Meio Ambiente. Disponível em: $<$ http://www.fem.unicamp.br>. Acesso em Jan 2005.

[39] Biomass Research and Development. Act 2000. Disponível em: $<$ http://www.usbiomassboard.gov>. Acesso em Mar 2007.

[40] ACIOLI, J.L. Fontes de Energia. Editora da Universidade de Brasília, p.277-279, 1994.

[41] GPEC, Grupo de Pesquisa em Engenharia de Custos. Energia Renovável: Gestão de Resíduos. Disponível em: <http://www.ufrnet.br > Acesso em: Jan 2012.

[42] Regulamentação e Incentivos às Energias Renováveis no Brasil PROINFA Brasília, 24 de maio de 2007 VI Encontro Fórum Permanente de Energias Renováveis Brasil Programa de Incentivo às Fontes Alternativas de Energia Elétrica-PROINFA.

[43] CIOLKOSZ, D. Introduction to biomassa combustion. Extention. Apr 2012. Disponível em: <http://www.extension.org >. Acesso em: Abr 2012.

[44] LIN, Y.; TANAKA, S. Ethanol fermentation form biomass resources. Appl Microbiol Biotechnol. 69 (6) p. 627-42, Feb 2006.

[45] BOUALLAGUI, $\mathrm{H}$. et al. Bioreactor performance in anaerobic digestion os fruit and vegetable wastes. Process Biochemistry, v.40, p.989-995, 2005.

[46] GERIS, R. et al. Biodiesel de soja: reação de transesterificação para aulas práticas de química orgânica. Química Nova, v.30, n.5, p.1369-1373, 2007.

[47] ZAINAL, Z.A., ET al., Experimental investigation of a downdraft biomass gasifier. Biomass and Bioenergy, v.23, n. 4, p.283-289, Oct 2002. 
[48] KALINA, J. Integrated biomass gasification combined cycledistributed generation plant with reciprocating gás engine and ORC. Appl Therm Engineer, v.31, n.14-15, p.2829-2840, 2011.

[49] SORDI, A. ET al. Gaseificação de biomassa e célula a combustível: sistema com célula tipo PEMFC. In Proceedings of the 6. Encontro de Energia no Meio Rural, Campinas, 2006.

[50] ALMEIDA, M.B.B. Bio-óleo a partir da pirólise rápida, térmica ou catalítica, da palha da cana-de-açúcar e seu co-processamento com gasóleo em craqueamento catalítico. 2008. Dissertação (Mestrado). Escola de Química da Universidade Federal do Rio de Janeiro, Rio de Janeiro.

[51] CARVALHO, F.M. A estratégia dos produtores de café com relação ao uso econômico de nitrogênio e potássio, município de Lavras-MG. 1992. Dissertação (Mestrado) - Escola Superior de Agricultura de Lavras, Minas Gerais.

[52] Usos da palha do café. Globo Rural - edição diária. 05 ago 2008. Disponível em: <http://www.globo.com>. Acesso em: Jan 2012.

[53] BRUM, S.D.; BIANCHI, M.L; SILVA, V.L.; GONÇALVES, M.; Guerreiro, M.C.; OLIVEIRA, L.C.A. Preparação e caracterização de carvão ativado produzido a partir de residuos do beneficiamento do café. Química Nova, São Paulo, v.31, n.5, 2008.

[54] PEREIRA, E., OLIVEIRA, L.C.A., VALLONE, A., SAPAG, K., PEREIRA, M. Preparação de carvão ativado em baixas temperaturas de carbonização a partir de rejeitos: utilização de $\mathrm{FeCl}_{3}$ como agente ativante. Química Nova, São Paulo, v.31, n.6, 2008.

[55] RAYMUNDO, A.S.; ZANAROTTO, R.; GALAZZI, R.M., BORGES, P.S.; RIBEIRO, J.N.; RIBEIRO, A.V.F.N. Estudo da casca/palha de café como adsorbente natural para remoção de corante textil. In: CONGRESSO BRASILEIRO DE QUÍMICA, 48, 2008, Rio de Janeiro. Anais Eletrônicos... Rio de Janeiro.

[56] REIS, M.O.; OLIVEIRA, L.S.; ROCHA, S.D. Adsorventes de residuos do beneficiamento de café.In: CONGRESSO BRASILEIRO DE ENGENHARIA QUÍMICA EM INICIAÇÃO CIENTÍFICA,VI, UNICAMP, 2005, Campinas. Anais Eletrônicos... Campinas.

[57] OLIVEIRA, E.R.A; SILVA, J.H.V.; COELHO, M.S. et al. Alimentos fibrosos para suínos. Pubvet, v.2, n.25, 2008. Disponível em: $<$ http://www.pubvet.com.br>. Acesso em: 2009. 
[58] PARRA, A.R.P; MOREIRA, I.;FURLAN, A.C.; PAIANO, D.;SCHERER, C.; CARVALHO, P.L.O. Utilização da casca de café na alimentação de suínos nas fases de crescimento e terminação. R.Bras.Zootec.

[59] OLIVEIRA, S.L.; FIALHO, E.T; MURGAS, L.D.S; FREITAS, R.T.F.; OLIVEIRA, A.I.G. Utilização de casca de café melosa em rações de suínos em terminação. Ciênc. Agrotec., v.26, n.6, Nov/Dez, 2002.

[60] GARCIA, I. F. F.; PEREZ, J.R.O.; TEIXEIRA, J.C.; BARBOSA, C.M.P. Desempenho de cordeiros Texel x Bergamácia, Texel x Santa Inês e Santa Inês puros, terminados em confinamento, alimentados com casca de café como parte da dieta. R. Bras. Zootec., v.29, n.2, Apr. 2000.

[61] NUNES, H.; ZANINE, A.M.; MACHADO, T.M.M; CARVALHO, F.C. Alimentos alternativos na dieta de ovinos. Asociación Latinoamericana de Producción Animal. Arch. Latinoam. de Prod. Anim. v.15, n.4, 2007. Disponível em: <http://www.alpa.org.ve>. Acesso em: Jan 2009.

[62] SOUZA, A.L.; GARCIA, R.; BERNARDINO, F.S.; ROCHA, F.C; VALADARES FILHO, S.C,;PEREIRA, O.G.; PIRES, A.J.V. Casca de café em dietas de carneiros: consumo e digestibilidade. R. Bras. Zootec., v.33, n.6, 2004.

[63] SOUZA, A.L.; GARCIA, R.; VALADARES FILHO, S.C.; ROCHA, F.C.; CAMPOS, J.M.S.; CABRAL, L.S.; GOBBI, K.F. Casca de café em dietas de vacas em lactação: consumo, digestibilidade e produção de leite. $\boldsymbol{R}$. Bras. Zootec., v.34, n.6, p.2496-2504, 2005.

[64] SOUZA, A.L.; GARCIA, R.; VALADARES, R.F.D.; PEREIRA, M.L.A.;CABRAL, L.S.; VALADARES FILHO, S.C. Casca de café em dietas para vacas em lactação: balanço de compostos nitrogenados e síntese de proteína microbiana. R. Bras. Zootec., v.35, n.4, 2006.

[65] SOUZA, A.L.; GARCIA, R.; BERNARDINO, F.S.; CAMPOS, J.M.S.; VALADARES FILHO, S.C.; CABRAL, L.S.; GOBBI, K.F. Casca de café em dietas de novilhas leiteiras: consumo, digestibilidade e desempenho. $\boldsymbol{R}$. Bras. Zootec., v.35, n.3, p.921-927, 2006.

[66] TEIXEIRA, R.M.A.; CAMPOS, J.M.S.; VALADARES FILHO, S.C.; OLIVEIRA, A.S.; ASSIS, A.J.; PINA, D.S. Consumo, digestibilidade e desempenho de novilhas alimentadas com casca de café em substituição à silagem de milho. R. Bras. Zootec., v.36, n.4, p.968-977, 2007.

[67] NASCIMENTO, C.G.H.; ANDRADE, I.F; BAIÃO, A.A.F.; MARTINS, A.E.; BAIÃO, E.A.M.; PÉREZ, J.R.O.; TEIXEIRA, J.C.; BAIÃO, L.A. Desempenho de novilhos Nelore mantidos em pastagem de Brachiaria decumbens, staff e suplementados com casca de café em substituição ao MDPS. Ciênc. Agrotec., Edição especial, p.1662-1671, 2003. Disponível em:< http://www.editora.ufla.br>. Acesso em: Jan 2009. 
[68] RIBEIRO FILHO, E.; PAIVA, P.C.A.; BARCELOS, A.F.; RESENDE, C.A.P.; CARDOSO, R.M.; BaANYS, V.L. feito da casca de café (Coffea arabica, L.) no desempenho de novilhos mestiços de HOLANDÊS-ZEBU na fase de recria. Ciênc. Agrotec., v.24, n.1, p.225-232, 2000. Disponível em:< http://www.editora.ufla.br>. Acesso em: Jan 2009.

[69] RIBEIRO FILHO, E.; PAIVA, P.C.A.;OLIVEIRA, E.R.; BARCELOS, A.F.; CASTRO, A.L.A.; SANTOS, J. Cinética da digestão ruminal da casca de café (Coffea arabica, L.) em vacas da raça Holandesa. Ciênc. Agrotec., V.28, n.3, p.627-636, 2004. Disponível em: < http://www.editora.ufla.br>. Acesso em: Jan 2009.

[70] FARIA, D.J.G.; GARCIA, R.; PEREIRA, O.G.; FONSECA, D.M.; MELLO, R.; RIGUEIRA, J.P.S. Composição químico-bromatológica da silagem de capim-elefante com níveis de casca de café. R. Bras. Zootec., v.36, n.2, p.301-308, 2007.

[71] SOUZA, A.L.; BERNARDINO, F.S.; GARCIA, R.; PEREIRA, O.G.; ROCHA, F.C.; PIRES, A.J.V. Valor nutritivo de silagem de Capim-Elefante (Pennisetum purpureum Schum.) com diferentes níveis de casca de café. $\boldsymbol{R}$. Bras. Zootec., v.32, n.4, p.828-833, 2003.

[72] CARVALHO, G.G.P.; GARCIA, R.; PIRES, A.J.V.; AZEVEDO, J.A.G.; FERNANDES F.E.P.; PEREIRA, O.G. Valor nutritivo e características fermentativas de silagens de capim-elefante com adição de casca de café. R. Bras. Zootec., v.36, n.6, 2007.

[73] CARVALHO, J.E.; ZANELLA, F.; MOTA, J.H.; LIMA, A.L.S. Cobertura morta do solo no cultivo de alface Cv Regina 2000, em Ji-Paraná/RO. Ciênc. Agrotec., v.29, n.5, p.935-939, 2005. Disponível em: < http://www.editora.ufla.br>. Acesso em: Jan 2009.

[74] ANDRADE JÚNIOR, V.C.; YURI, J.E.; NUNES, U.R.; PIMENTA, F.L.; MATOS, C.S.M.; FLORIO, F.C.A.; MADEIRA, D.M. Emprego de tipos de cobertura de canteiro no cultivo da alface. Hortic. Bras., v.23, n.4, p.225232, 2005.

[75] SIVÉRIO, F.O.; BARBOSA, C.C.; PILÓ-VELOSO, D. A pirólise como técnica analítica. Química Nova, v.31, n.6, p. 1543-1552, 2008.

[76] GÓMEZ, E.O.; CORTEZ, L.A.B,; PEREZ, J.M. et. al. Pirólise rápida contínua de biomassa com ar em reator de leito fluidizado atmosférico. In Proceedings of the 3. Encontro de Energia no Meio Rural, Campinas, 2003.

[77] PÉREZ, J.M.M. Testes em uma planta de pirólise de biomassa em leito fluidizado: critérios para sua otimização. 2004.Tese (Doutorado) Universidade Estadual de Campinas, Campinas. 
[78] SPINACE, M.A.S.; DE PAOLI, M.A. A tecnologia da reciclagem de polímeros. Química Nova, v.28, n.1, p.65-72, 2005.

[79]DEMIRBAS, A.J. Green energy and technology. Biorefineries, v.1 p. 227-235, 2010.

[80] OASMAA, A. Fast pyrolysis bio-oils from wood and agricultural residues. Energy Fuels,v.24, p.1380-1388, Feb 2010.

[81] BRIENS, C.; PISKORZ, J.; BERRUTI, F. Biomass valorization for fuel and chemicals productions - a review. Intern Journ Chem Reac Engineer, v.6, p.1-51, 2008.

[82] EIJA, A.; VALTANEN, J. LEVLIN, J.E. CEN technical specifications for solid biofuels - Fuel specification and classes. Biomass and Bioenergy, v.30, p.908-914, 2006.

[83] BERRUTI, F. et al. Novel fluid bed pilot plant for the production of bio-oil from biomass through fast pyrolysis. In: Proceedings 1. International Congress on Green process Engineering, Toulouse, Apr 2007.

[84] BLACKABY, N. Burning desire for power. Power Engineering International, v. 13, p.27029, 2005.

[85] BLADES, T. Germany: choren uses alternative route to biomass fuel. Industrial Bioprocessing, v.29, n.5, p.9-10, 2007.

[86] BOUKIS, I. et al. CBF air-blow fhash pyrolysis. Fuel, v.86, p.1372-1395, 2007.

[87] BRIDGWATER, A.V. Fast pyrolysis processes for biomass. Renewable and Sustainable Energy Reviews, v.4, p.1-73, 2000.

[88] BRIDGWATER, A.V., Biomass fast pyrolysis. Thermal Science, v.8, p.21-49, 2004.

[89] CHIARAMONTI, D.; OASMAA, A.; SOLANTAUSTA, Y. Power generation using fast pyrolysis liquids from biomass. Renewable and Sustainable Energy Reviews, v.11, p.1056-1086, 2007.

[90] IKURA, M. et al Emulsification of pyrolysis derived bio-oil in diesel fuel. Biomass and Bioenergy, v.24, p.221-232, 2003.

[91] MARCHETTI, J.M. et al. Possible methods for biodiesel production. Renewable and Sustainable Energy Reviews, v.11, p.1300-1311, 2007. 
[92] MEHER, L.C. et al. Technical aspects of biodiesel production by transesterification - a review. Renewable and Sustainable Energy Reviews, v. 10, p.248-268, 2006.

[93] MOREY, $R$ et al. Biomass for electricity and process heat at ethanol plants. App Engineer Agric, v. 22, p.723-726, 2006.

[94] OBERNBERGER, I.; THEK, G. Physical characterization and chemical composition of dandified biomass fuels with regard to their combustion behavior. Biomass and Bioenergy, v.27, p.653-669, 2004.

[95] OLSSON, M. Wheat straw and peat for fuel pellets organic compounds from combustion. Biomass and Bioenergy, v. 30, p.555-564, 2006.

[96] PATZEK, T.W. A first-law thermodynamic analysis of the corn-ethanol cycle. Natural Resources Research, v.15, p.255-270, 2006.

[97] QI, Z. et al. Review of biomass pyrolysis oil properties and upgrading research. Energy Conservation and Management, v.48, p.87-92, 2007.

[98] FIGUEIREDO, R.A.. Caracterizacao dos Produtos da Pirolise daCasca de Castanha de Caju: Influencia da Taxa de Aquecimento e da Temperatura. 2011. Tese (Doutorado) - Universidade Estadual de Campinas, Campinas, SP.

[99] KIMURA, L.M. Uma contribuição à pirólise de biomassa: Avaliação de alguns resíduos da agroindústria como fonte de energia alternativa. 2009, Dissertação (Mestrado) - Universidade Federal de Uberlândia, Uberlândia, MG.

[100] DINIZ, J. Conversão térmica de casca de arroz à baixa temperatura: produção de bioóleo e resíduo sílico-carbonoso adsorvente. 2005. Tese (Doutorado) - Universidade Federal de Santa Maria, Santa Maria, RS.

[101] SATER O. et al. Estudo comparativo da carbonização de resíduos agrícolas e florestais visando à substituição da lenha no processo de secagem de grãos de café. Revista Ceres, v.58, n.6, p.717-722, 2011.

[102] TACCINI, M.M. Estudo das metodologias da CQNUMC, referentes à avaliação de emissões de gases de efeito estufa na produção de carvão vegetal. 2010. Dissertação (Mestrado) - Escola Superior de Agricultura Luiz de Queiroz, Piracicaba, SP.

[103] GEORGES, F. Caracterização da palha da cana-de-açúcar do Rio Grande do Sul e seus produtos de pirólise. 2011. Dissertação (Mestrado) - Universidade Federal do Rio Grande do Sul, Porto Alegre, RS 
[104] CARDOSO, A.L. Pirólise lenta de serragem de eucalipto para obtenção de bioóleo e carvão. 2004. Dissertação (Mestrado) Universidade Federal de Santa Maria, Santa Maria, RS

[105] TIAGO F०, G.L. Energias Renováveis, 1ed, MME Ministério de Minas e Energia, Itajubá, 2007.

[106] PENNER, S.S. Steps Toward the Hydrogen Economy. Energy, 31, p. 33-43, 2006.

[107] GOMES NETO, E.H. Hidrogênio - Evoluir sem poluir. Curitiba, PR: H2 Fuel Cell Energy, 2005.

[108] MIDILLIA, A. ; DINCERB, I. Key strategies of hydrogen energy systems for sustainability. International Journal of hydrogen Energy, n.32, p.511-524, 2007.

[109] EDWARDS, P.P.A. et al. Hydrogen and fuel cells: Towards a sustainable energy future. Energy Policy, n.36, p.4356-4362, 2008.

[110] BLANCHETTE JR, S. A hydrogen economy and its impact on the world as we know it. Energy Policy, n.36, p.522-530, 2008.

[111] MCDOWALL, W.; EAMES, M. Towards a sustainable hydrogen economy: A multi-criteria sustainability appraisal of competing hydrogen futures. International Journal of Hydrogen Energy, n.32, p.4611-4626, 2007.

[112] RUIJVENA, B. et al. The potencial role of hydrogen in energy systems with and without climate policy. International Journal of Hydrogen Energy, n.32, p.1655-1672, 2007.

[113] WENDT, H.; GOTZ M.; LINARDI, M. Tecnologia de células a combustível. Química Nova, v.23 (4), p.538-546, 2000.

[114] WENDT, H.; LINARDI, M.; ARICÓ, E.M. Células a combustível de baixa potência para aplicações estacionárias. Química Nova, v.25 (3), p.470-476, 2002.

[115] GOMES NETO, E.H. Fontes de Hidrogênio: Conteúdo de Células a Combustível. Disponível em:<http://ambientebrasil.com.br $>$. Acesso em Mar 2012.

[116] LINARDI, M. Introdução à ciência e tecnologia de células a combustível. 1ed. São Paulo, SP: Artiber, 2010.

[117] EGUTE, N.S. Estudo do processo para a aceleração da geração de amônia a partir de resíduos avícolas visando à produção de 
hidrogênio. 2010. Dissertação (Mestrado) - Instituto de Pesquisas Energéticas e Nucleares, IPEN, São Paulo.

[118] BERNARDI JR, P. Alternativas para a produção de hidrogênio nas regiões brasileiras visando à geração de energia elétrica distribuída. 2009. Tese (Doutorado) - Instituto de Pesquisas Energéticas e Nucleares, IPEN, São Paulo.

[119] ALDABÓ, R. Células combustível a hidrogênio - Fonte de energia da nova era. 1ed.São Paulo, SP: Artliber, 2004.

[120] VIEIRA, G.E.G. O processo de pirólise como alternativa para o aproveitamento do potencial energético de lodo de esgoto - uma revisão. Revista Liberato, Novo Hamburgo, v.12, n.17, p.1-106, jan/jun 2011.

[121] GÓMEZ, E.O. et al. Projeto de pirólise rápida continua de biomassa com ar em reator de leito fluidizado atmosférico. In: ENCONTRO DE ENERGIA NO MEIO RURAL, 3, Set. 2000, Campinas, SP. Proceedings...Campinas, 2000. 1 CD-ROM.

[122] VIEIRA, G.E.G. Fontes alternativas de energia - Processo aperfeiçoado de conversão térmica. 2004. Tese (Doutorado) Universidade Federal Fluminense, Rio de Janeiro.

[123] Cocatrel, Cooperativa dos Cafeicultores da Zona de Três Pontas Ltda. Disponível em: < http://www.cocatrel.com.br >. Acesso em: Mai, 2007.

[124] SOUZA, L.A. Poder calorífico de combustíveis. Disponível em: $<$ http://www.mundoeducacao.com.br/quimica/poder-calorifico-

combustiveis.htm>. Acesso em Jun 2012.

[125] CORBANI, R.Z. Estudo do extrato pirolenhoso BIOPIROL ${ }^{R}$ no manejo de nematoides em cana-de-açúcar, olerícolas e citros, em diferentes ambientes. 2008. Tese (Doutorado) - UNESP - Jaboticabal, São Paulo

[126] GLASS, V. Onde há fumaça há lucro. Revista Globo Rural, ed.188, 15/09/2004.

[127] FIGUEIREDO, F.A.B. Pirólise e gaseificação de casca de castanha de caju: avaliação da produção de gás, líquidos e sólidos. 2009. Tese (Doutorado) - UNICAMP, São Paulo. 